\title{
Final Report on Phase III Testing of Monosodium Titanate Adsorption Kinetics
}

by

D. T. Hobbs

Westinghouse Savannah River Company

Savannah River Site

Alken, South Carolina 29808

M. G. Bronlkowski

T. B. Edwards

R. L. Pulmano

DOE Contract No. DE-AC09-96SR18500

This paper was prepared in connection with work done under the above contract number with the U.S. Department of Energy. By acceptance of this paper, the publisher and/or recipient acknowledges the U.S. Government's right to retain a nonexclusive, royalty-free license in and to any copyright covering this paper, along with the right to reproduce and to authorize others to reproduce all or part of the copyrighted paper. 


\section{DISCLAIMER}

This report was prepared as an account of work sponsored by an agency of the United States Government. Neither the United States Government nor any agency thereof, nor any of their employees, makes any warranty, express or implied, or assumes any legal liability or responsibility for the accuracy, completeness, or usefulness of any information, apparatus, product, or process disclosed, or represents that its use would not infringe privately owned rights. Reference herein to any specific commercial product, process, or service by trade name, trademark, manufacturer, or otherwise does not necessarily constitute or imply its endorsement, recommendation, or favoring by the United States Government or any agency thereof. The views and opinions of authors expressed herein do not necessarily state or reflect those of the United States Government or any agency thereof.

This report has been reproduced directly from the best available copy.

Available to DOE and DOE contractors from the Office of Scientific and Technical Information, P.O. Box 62, Oak Ridge, TN 37831; prices available from (615) 576-8401.

Available to the public from the National Technical Information Service, U.S. Department of Commerce, 5285 Port Royal Road, Springfield, VA 22161. 


\section{Final Report on Phase III Testing of Monosodium Titanate Adsorption Kinetics}

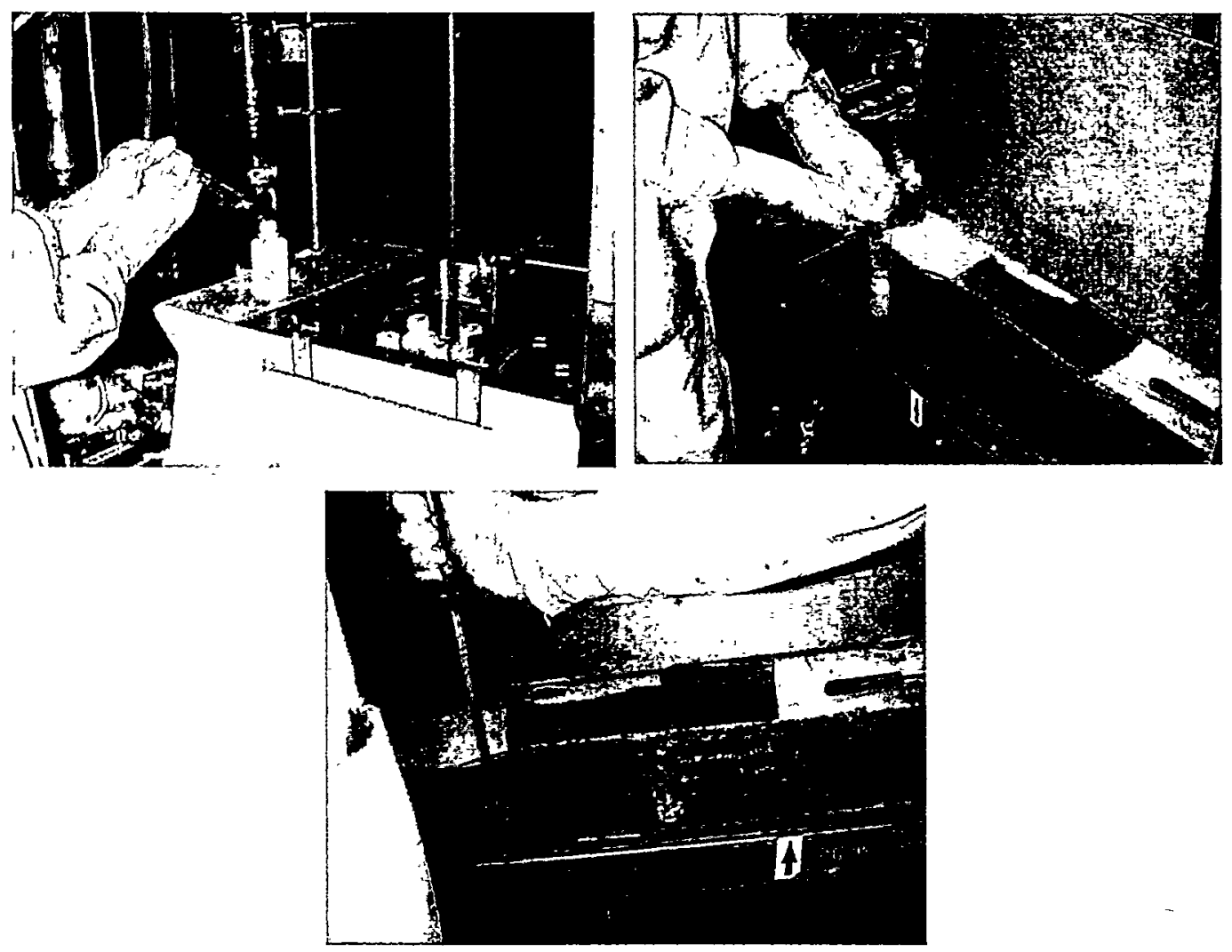

D. T. Hobbs, 773-A

M. G. Bronikowski, 773-A

T. B. Edwards, 773-42A

R. L. Pulmano, 773-24A

Publication Date: May 28, 1999

Westinghouse Savannah River Company

Savannah River Technology Center

A iken, SC 29808

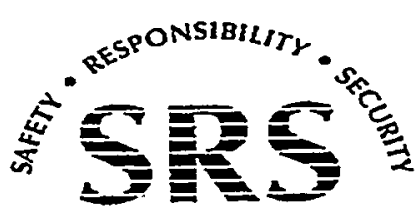




\section{DISCLAIMER}

Portions of this document may be illegible in electronic image products. Images are produced from the best available original document. 
WSRC-TR-99-00134

Revision 0

\section{Final Report on Phase III Testing of Monosodium Titanate Adsorption Kinetics}

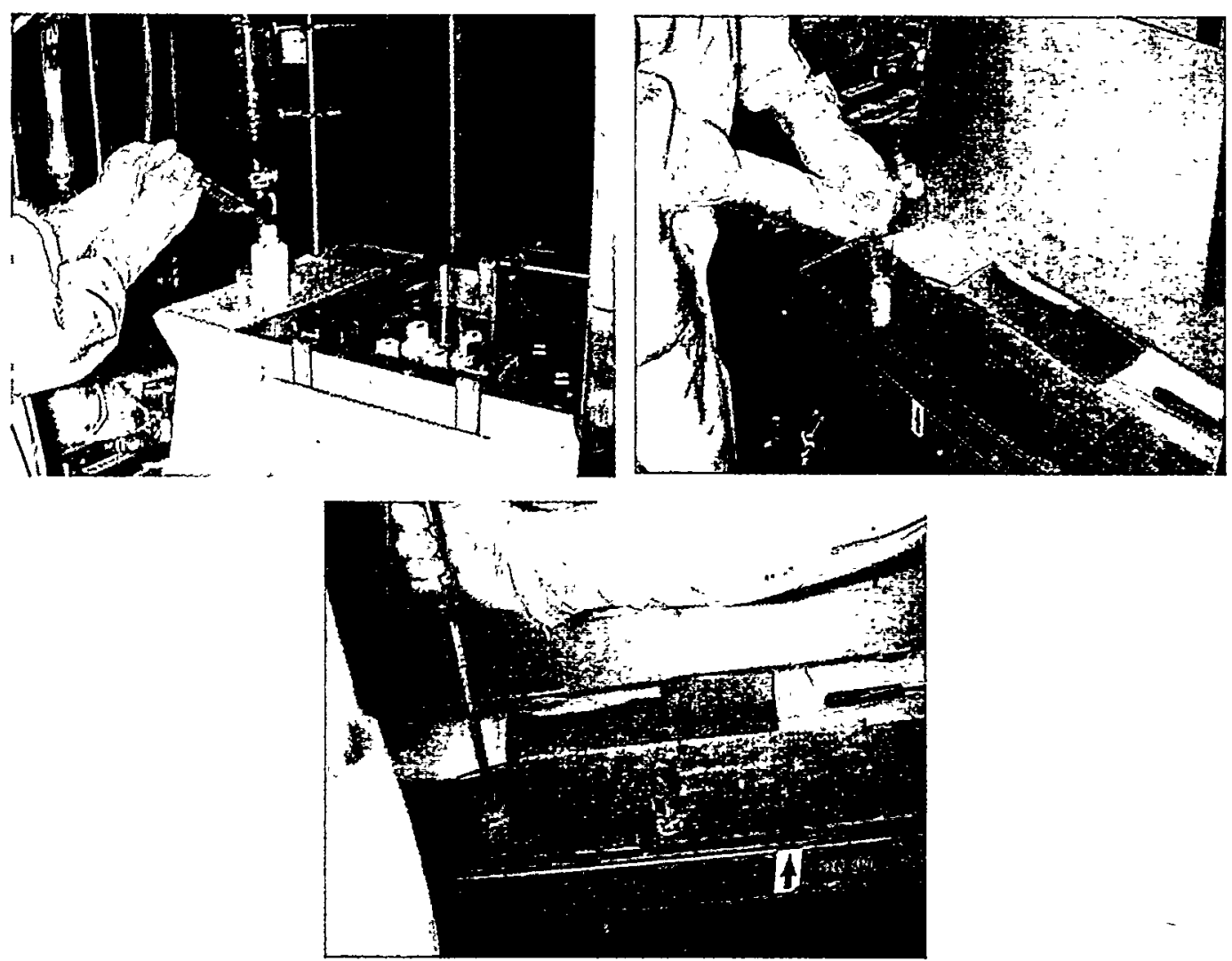

D. T. Hobbs, 773-A

M. G. Bronikowski, 773-A

T. B. Edwards, 773-42A

R. L. Pulmano, 773-24A

Publication Date: May 28, 1999

Westinghouse Savannah River Company Savannah River Technology Center A iken, SC 29808

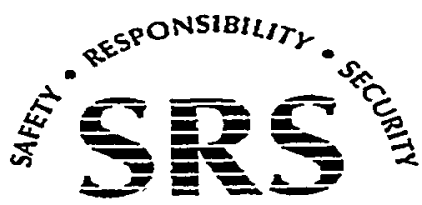


WSRC-TR-99-00134

Page 2 of 88

Revision 0

Author

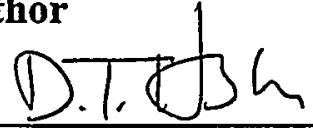

$5 / 30 / 99$

D. T. Hobbs, Waste Processing Technology Section

Date

M. S. Bronikowak?

$6 / 1 / 99$

M. G. Bronikowski, Chemical and Hydrogen Technology Section Date

$\frac{\text { Thomas \& Sdasands }}{\text { T. B. Edwards, Statistical Consulting Section }}$ C/1/99

$\frac{\text { Rchewar L. Phlmanas }}{6 / 2 / 99}$

Design Check

Barrel D. Walker silas

D. D. Walker, Waste Processing Technology Section Date (per Manual E7, Procedure 2.40)

Approvals

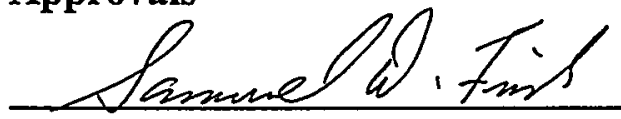

S. D. Fink, Level 4 Manager, Waste Processing Technology
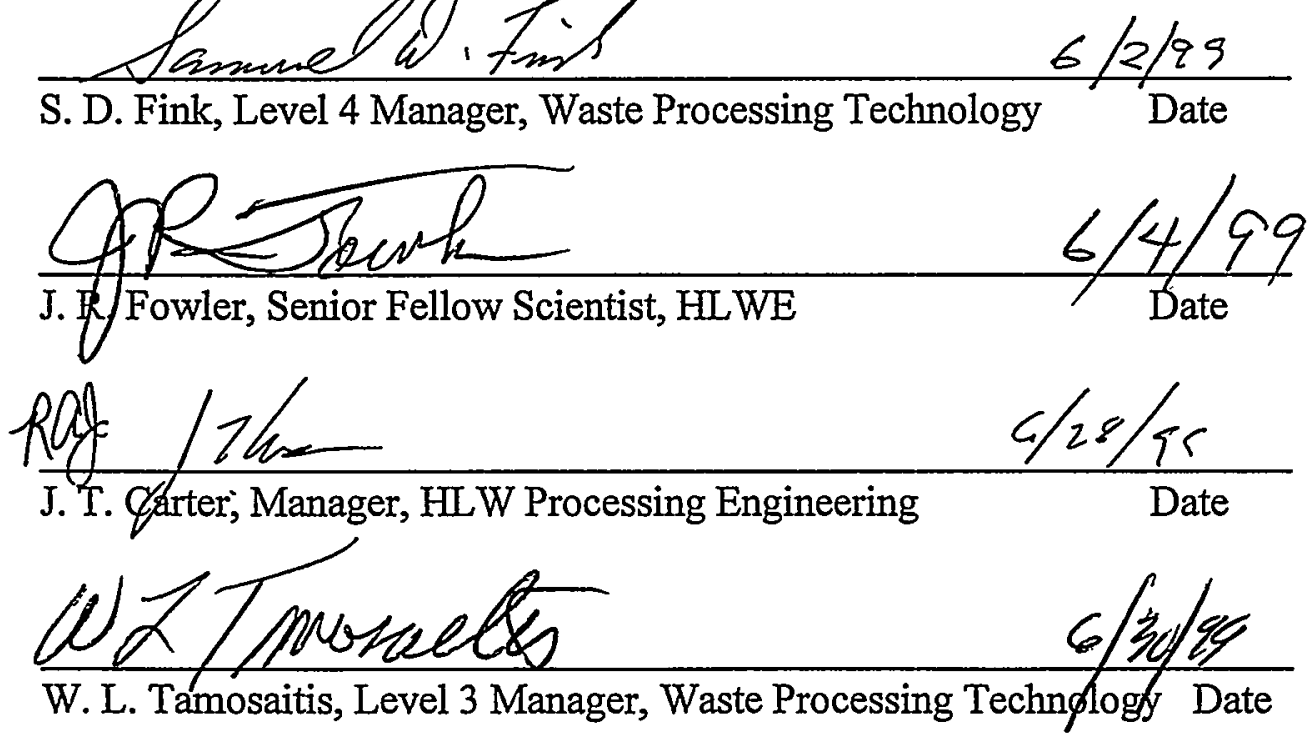


\section{Summary}

Testing examined the effects of ionic strength (i.e., $4.91,6.55$ and $8.20 \mathrm{M}$ or at a Na${ }^{+}$concentration of 4.5, 6.0 and 7.5 M), temperature (i.e., 25,45 and $65^{\circ} \mathrm{C}$ ), mixing (i.e., 0, 200 and $700 \mathrm{rpm}$ ), sludge solids (i.e., 0 and $400 \mathrm{mg} / \mathrm{L}$ ), and sodium tetraphenylborate (i.e., NaTPB at 0 and $400 \mathrm{mg} / \mathrm{L}$ ) on the extent and rate of strontium, plutonium, neptunium and uranium removal by adsorption onto monosodium titanate (MST). The tests examined performance at different concentrations of strontium ( 4.96 to $106 \mu \mathrm{g} / \mathrm{L}$ ), plutonium ( 0.56 to $280 \mu \mathrm{g} / \mathrm{L}$ ), uranium (1520 to $26000 \mu \mathrm{g} / \mathrm{L}$ ) and neptunium (340 to $35800 \mu \mathrm{g} / \mathrm{L}$ ) in simulated high-level waste solutions containing different masses of MST.

The more important parameters affecting sorption include initial sorbate concentration, MST concentration, ionic strength and temperature. The presence of NaTPB did not significantly affect the removal of any sorbate. Strontium, plutonium and uranium removal increased slightly in the presence of synthetic sludge solids. Strontium and plutonium removal, but not uranium and neptunium removal, decreased slightly in tests when the only mixing involved shaking for sampling. Moderate versus vigorous mixing did not affect removal of strontium, plutonium or neptunium (uranium not determined). The affects of mixing and sludge solids proved small compared to those observed for initial sorbate concentration, MST concentration, ionic strength and temperature.

Testing results indicated successful decontamination of a $4.5 \mathrm{M} \mathrm{Na}^{+}$salt solution within Z-Area limits for Sr-90, total alpha activity and Np-237 by adding $0.2 \mathrm{~g} / \mathrm{L}$ MST. At the higher sodium ion concentration $\left(7.5 \mathrm{M} \mathrm{Na}{ }^{+}\right)$, the equilibrium concentrations did not always satisfy Z-Area limits indicating a higher MST concentration is required at higher ionic strength.

Removal rates determined at the lowest MST concentration provide data for sizing continuously stirred tank reactors and batch tanks for the various Salt Disposition Alternative flowsheets. Qualitatively, the removal rates appear sufficiently rapid for any of the alternatives. We recommend additional testing with simulants at lower neptunium concentrations and with radioactive waste to confirm the results of this testing.

From statistical analysis of the data, the authors derived equations for predicting the equilibrium solution concentrations for each sorbate. Models for strontium, uranium and neptunium exhibited good fits as evidence by high correlation coefficients $\left(r^{2}>0.97\right)$. We attribute the poorer fit for the plutonium results $\left(r^{2}=0.789\right)$ to the large number of equilibrium concentrations falling below the detection limits of the analytical methods. We recommend further analysis of the composite data following the additional recommended tests -- using available adsorption models (e.g., Freundlich and Langmuir) to develop better predictive models of this multi-sorbate system. 


\section{Contents}

Summary

Contents

List of Figures

List of Tables

Introduction

Experimental

Preparation of Treated Salt Solutions

Preparation of High Activity Salt Solutions

8

Preparation of Low Activity Salt Solutions

Adsorption Tests

\section{Results and Discussion}

Experimental Design 14

Control Samples 16

Removal Efficiency Criteria $\quad 17$

Extent of Strontium Removal 18

Extent of Plutonium Removal 20

Extent of Uranium Removal 23

Extent of Neptunium Removal 26

Equilibrium Distribution Constants 29

Models for Predicting Equilibrium Sorbate Concentrations

$\begin{array}{ll}\text { Equilibrium Sorbate Concentrations } & 33\end{array}$

Strontium $\quad 33$

Plutonium $\quad 34$

Uranium $\quad 34$

Neptunium $\quad 34$

Removal Rates 34

Batch Removal of Strontium, Plutonium, Uranium and Neptunium 37

Quality Assurance $\quad 38$

Acknowledgements $\quad 38$

$\begin{array}{ll}\text { References } & 38\end{array}$

Appendices

Appendix 1. Concentration versus Time Data for Control Samples 40

Appendix 2. Strontium Concentrations in Control Samples 41

Appendix 3. Plutonium Concentrations in Control Samples 42

Appendix 4. Uranium Concentrations in Control Samples 43

Appendix 5. Neptunium Concentrations in Control Samples 44

Appendix 6. Equilibrium Distribution Constants at $25^{\circ} \mathrm{C}$ 


\section{Contents (continued)}

page

Appendix 7. Equilibrium Distribution Constants at $45^{\circ} \mathrm{C}$

46

Appendix 8. Equilibrium Distribution Constants at $65^{\circ} \mathrm{C} \quad 47$

Appendix 9. Calculation of Np-237 Concentration in SRS 48

High-Level Waste

Appendix 10. Concentration versus Time Data for Tests at

4.5 $\mathrm{M} \mathrm{Na}^{+}, 0.2 \mathrm{~g} / \mathrm{L} \mathrm{MST}$, Low Activity Solution

Appendix 11. Concentration versus Time Data for Tests at 50

4.5 $\mathrm{M} \mathrm{Na}^{+}, 2.0 \mathrm{~g} / \mathrm{L} \mathrm{MST,} \mathrm{Low} \mathrm{Activity} \mathrm{Solution}$

Appendix 12. Concentration versus Time Data for Tests at

6.0 $\mathrm{M} \mathrm{Na}^{+}, 1.1 \mathrm{~g} / \mathrm{L} \mathrm{MST}$, Low Activity Solution

Appendix 13. Concentration versus Time Data for Tests at 52

6.0 $\mathrm{M} \mathrm{Na}^{+}, 1.1 \mathrm{~g} / \mathrm{L} \mathrm{MST}$, Low Activity Solution, No Mixing

Appendix 14. Concentration versus Time Data for Tests at

6.0 $\mathrm{M} \mathrm{Na}^{+}, 1.1 \mathrm{~g} / \mathrm{L} \mathrm{MST}$, Low Activity Solution, NaTPB or Sludge Added

Appendix 15. Concentration versus Time Data for Tests at $7.5 \mathrm{M} \mathrm{Na}^{+}, 0.2 \mathrm{~g} / \mathrm{L}$ MST, Low Activity Solution

Appendix 16. Concentration versus Time Data for Tests at 7.5 $\mathrm{M} \mathrm{Na}^{+}, 2.0 \mathrm{~g} / \mathrm{L} \mathrm{MST}$, Low Activity Solution

Appendix 17. Concentration versus Time Data for Tests at 56

4.5 $\mathrm{M} \mathrm{Na}^{+}, 0.2 \mathrm{~g} / \mathrm{L} \mathrm{MST}$, High Activity Solution

Appendix 18. Concentration versus Time Data for Tests at

4.5 $\mathrm{M} \mathrm{Na}^{+}, 2.0 \mathrm{~g} / \mathrm{L} \mathrm{MST}$, High Activity Solution

Appendix 19. Concentration versus Time Data for Tests at 58

$6.0 \mathrm{M} \mathrm{Na}^{+}, 1.1 \mathrm{~g} / \mathrm{L} \mathrm{MST}$, High Activity Solution

Appendix 20. Concentration versus Time Data for Tests at 59

6.0 $\mathrm{M} \mathrm{Na}^{+}, 1.1 \mathrm{~g} / \mathrm{L} \mathrm{MST}$, High Activity Solution, No Mixing

Appendix 21. Concentration versus Time Data for Tests at

6.0 $\mathrm{M} \mathrm{Na}^{+}, 0.2 \mathrm{~g} / \mathrm{L} \mathrm{MST}$, High Activity Solution, NaTPB or Sludge Added

Appendix 22. Concentration versus Time Data for Tests at $7.5 \mathrm{M} \mathrm{Na}^{+}, 0.2 \mathrm{~g} / \mathrm{L} \mathrm{MST}$, High Activity Solution

Appendix 23. Concentration versus Time Data for Tests at

$7.5 \mathrm{M} \mathrm{Na}^{+}, 2.0 \mathrm{~g} / \mathrm{L} \mathrm{MST}$, High Activity Solution

Appendix 24. Mole Ratios of Sorbates to MST 
Figure 1A. Lab Line Orbital Shaker Waterbath

Figure 1B. Isotemp Waterbath

Figure 2. Waterbath Temperature Profiles at $25^{\circ} \mathrm{C}$

Figure 3. Waterbath Temperature Profiles at $45^{\circ} \mathrm{C}$

Figure 4. Waterbath Temperature Profiles at $65^{\circ} \mathrm{C}$

Figure 5. Strontium Removal - 4.5 $\mathrm{M} \mathrm{Na}^{+}$, Low Activity, $0.2 \mathrm{~g} / \mathrm{L} \mathrm{MST}$

Figure 6. Strontium Removal - 4.5 $\mathrm{M} \mathrm{Na}^{+}$, High Activity, $0.2 \mathrm{~g} / \mathrm{L} \mathrm{MST}$

Figure 7. Strontium Removal - 7.5 $\mathrm{M} \mathrm{Na}^{+}$, Low Activity, $0.2 \mathrm{~g} / \mathrm{L} \mathrm{MST}$

Figure 8. Strontium Removal - 7.5 $\mathrm{M} \mathrm{Na}^{+}$, High Activity, $0.2 \mathrm{~g} / \mathrm{L} \mathrm{MST}$

Figure 9. Plutonium Removal - 4.5 $\mathrm{M} \mathrm{Na}^{+}$, Low Activity, $0.2 \mathrm{~g} / \mathrm{L} \mathrm{MST}$

Figure 10. Plutonium Removal - 4.5 $\mathrm{M} \mathrm{Na}^{+}$, High Activity, $0.2 \mathrm{~g} / \mathrm{L}$ MST 21

Figure 11. Plutonium Removal - 7.5 $\mathrm{M} \mathrm{Na}^{+}$, Low Activity, $0.2 \mathrm{~g} / \mathrm{L}$ MST 22

Figure 12. Plutontium Removal - 7.5 $\mathrm{M} \mathrm{Na}^{+}$, High Activity, $0.2 \mathrm{~g} / \mathrm{L}$ MST 22

Figure 13. Uranium Removal - 4.5 $\mathrm{M} \mathrm{Na}^{+}$, Low Activity, $0.2 \mathrm{~g} / \mathrm{L} \mathrm{MST} 24$

Figure 14. Uranium Removal - 4.5 $\mathrm{M} \mathrm{Na}^{+}$, High Activity, $0.2 \mathrm{~g} / \mathrm{L} \mathrm{MST}$

Figure 15. Uranium Removal - 7.5 $\mathrm{M} \mathrm{Na}^{+}$, Low Activity, $0.2 \mathrm{~g} / \mathrm{L}$ MST 25

Figure 16. Uranium Removal - 7.5 $\mathrm{M} \mathrm{Na}^{+}$, High Activity, $0.2 \mathrm{~g} / \mathrm{L} \mathrm{MST}$

Figure 17. Neptunium Removal - 4.5 $\mathrm{M} \mathrm{Na}^{+}$, Low Activity, $0.2 \mathrm{~g} / \mathrm{L}$ MST 27

Figure 18. Neptunium Removal - 4.5 $\mathrm{M} \mathrm{Na}^{+}$, High Activity, $0.2 \mathrm{~g} / \mathrm{L}$ MST 27

Figure 19. Neptunium Removal - 7.5 $\mathrm{M} \mathrm{Na}^{+}$, Low Activity, $0.2 \mathrm{~g} / \mathrm{L}$ MST 28

Figure 20. Neptunium Removal - 7.5 $\mathrm{M} \mathrm{Na}^{+}$, High Activity, $0.2 \mathrm{~g} / \mathrm{L} \mathrm{MST} \quad 28$

Figure 21. Affect of Mixing on Strontium Removal 31

Figure 22. Affect of Mixing on Plutonium Removal 32

Figure 23. Affect of Mixing on Neptunium Removal 32 


\section{List of Tables}

page

Table I. Composition of Salt Solution

Table II. Concentration of Major Metal Components in

Synthetic Purex Sludge

Table III. Average and Mean Waterbath Temperatures

Table IV. Test Conditions in Additional Mixing Tests

Table V. Targeted Parameter Values

Table VI. Statistical Design Test Outline 16

Table VII. Sr-90 Limits Converted to Total Strontium Mass Limits 17

Table VIII. Plutonium Mass Concentration Limits 18

Table IX. Average Equilibrium Uranium Decontamination Factors 23

Table X. Summary of Statistical Model Parameters for Mixing 30 and Spiked Trials

Table XI. Incremental Removal Rates for Strontium Upon Reaching

Sr-90 Limit for Feed of Decontaminated Salt Solution to Z-Area

Table XII. Incremental Removal Rates for Plutonium Upon Reaching Total

Alpha Limit for Feed of Decontaminated Salt Solution to Z-Area

Table XIII. Incremental Removal Rates for Neptunium Upon Reaching

Np-237 Limt for Feed of Decontaminated Salt Solution to Z-Area

Table XIV. Estimated Times from Sampling Intervals to Reach Equilibrium 


\section{Introduction}

The Salt Disposition Systems Engineering Team identified the adsorption kinetics of actinides and strontium onto monosodium titanate (MST) as a technical risk for several of the processing alternatives selected for evaluation in Phase III of their effort. The Flow Sheet Team requested that the Savannah River Technology Center (SRTC) examine the adsorption kinetics of MST for several process alternatives [1].

Previously, Hobbs and Walker studied the adsorption of plutonium and uranium onto MST in alkaline solutions [2]. Results of these tests indicate that MST would remove strontium, uranium and plutonium from simulated In-Tank Precipitation (ITP) waste solutions. Hobbs and Fleischman followed with statistically designed testing to examine temperature and chemical composition [3]. Again, the results clearly indicate that MST would sufficiently remove strontium, uranium and plutonium. However, the previous studies did not examine the kinetics of the adsorption process.

This study consisted of a statistically designed set of tests to determine the extent and rate of adsorption of strontium, plutonium, uranium, and neptunium as a function of temperature, MST concentration, and concentrations of sodium, strontium, plutonium, uranium and neptunium. Additional tests incorporated into the design assess the effects of mixing as well as the influence from the presence of sludge solids and sodium tetraphenylborate. The Statistical Consulting Section of SRTC assisted in the design of experiments [4].

\section{Experimental}

Preparation of Treated Salt Solution

Personnel prepared 10 liters of a synthetic salt solution from reagent grade chemicals and deionized, distilled (DDI) water yielding the composition provided in Table I. The composition of the salt solution is scaled to that previously used in MST testing of actinide loading and maximizes solubility of plutonium and uranium [5]. Filtering of undissolved solids occurred using Whatman \#1 filter paper. Researchers then mixed the filtered solution with 133 grams of MST slurry (20 grams MST, Optima Batch \#33407), and stirred the resulting mixture at laboratory temperature for 48 hours before filtering it through a medium porosity sintered-glass funnel to remove strontium impurities present in the reagent grade chemicals. They repeated this MST treatment using 15 grams of MST slurry (2.3 grams MST, Optima Batch \#33407), stirring the mixture at ambient laboratory temperature for 72 hours and filtering it through a medium porosity sintered glass funnel. Inductively coupled plasma mass spectrometry (ICP-MS) analysis of the treated solution indicated a strontium concentration of $0.096 \mathrm{mg} / \mathrm{L}$.

\section{Table I. Composition of Salt Solution}

\begin{tabular}{lc} 
Component & Concentration (M) \\
\cline { 2 - 2 } $\mathrm{NaNO}_{3}$ & 3.47 \\
$\mathrm{NaOH}$ & 1.78 \\
$\mathrm{Na}_{2} \mathrm{SO}_{4}$ & 0.694 \\
$\mathrm{NaAl}(\mathrm{OH})_{4}$ & 0.572 \\
$\mathrm{NaNO}_{2}$ & 0.178 \\
$\mathrm{Na}_{2} \mathrm{CO}_{3}$ & 0.0347 \\
Total Na$^{+}$ & 7.46
\end{tabular}


Preparation of High Activity Salt Solutions

Researchers placed $4.8 \mathrm{~L}$ of the treated salt solution in a clean 8-L polyethylene (PE) carboy. Next, personnel added $5.0 \mathrm{~mL}$ of a nitric acid solution containing $22.13 \mathrm{mg} / \mathrm{mL}$ uranium, $1.12 \mathrm{mg} / \mathrm{mL}$ plutonium and $50.2 \mathrm{mg} / \mathrm{mL}$ neptunium and $0.100 \mathrm{~mL}$ of a solution containing $104 \mathrm{mg} / \mathrm{mL}$ strontium nitrate. The solution stirred at ambient laboratory temperature for 11 days. Next, the test method required pipetting $1.00 \mathrm{~mL}$ of Sr-85 (New England Nuclear, NEZ082, $9.03 \mathrm{mCi} / \mathrm{mg} \mathrm{Sr}$ ) in hydrochloric acid $(0.28 \mathrm{mCi} / \mathrm{mL})$ into the solution and stirring overnight. The researchers then pipetted $0.50 \mathrm{~mL}$ of Sr-85 in hydrochloric acid $(0.28 \mathrm{mCi} / \mathrm{mL})$ into the solution and stirred it overnight before filtering it through a $0.45-\mu \mathrm{m}$ pore size, disposable (cellulose nitrate) membrane filter. Personnel then pipetted $1.00 \mathrm{~mL}$ of Sr-85 in hydrochloric acid $(0.28 \mathrm{mCi} / \mathrm{mL})$ into the solution and stirred overnight. The final addition used $1.50 \mathrm{~mL}$ of Sr- 85 in hydrochloric acid $(0.28 \mathrm{mCi} / \mathrm{mL})$ followed by 3 days of agitation. Finally, researchers filtered the suspension through a $0.45-\mu \mathrm{m}$ pore size, disposable (cellulose nitrate) membrane filter and stored in a clean $8 \mathrm{~L} \mathrm{PE}$ carboy labeled as " 7.5 M High".

Researchers prepared a " $6.0 \mathrm{M}$ High" stock by adding distilled, deionized water to a sufficient amount of the $7.5 \mathrm{M}$ High solution in a clean PE bottle to produce $2.75 \mathrm{~L}$ of solution with a final sodium concentration of $6.0 \mathrm{M}$. Similarly, researchers prepared 1.5 liters of a " $4.5 \mathrm{M}$ High" stock by dilution.

\section{Preparation of Low Activity Salt Solutions}

Researchers placed $4.8 \mathrm{~L}$ of the treated salt solution in a clean $8 \mathrm{~L} \mathrm{PE}$ carboy and added $0.400 \mathrm{~mL}$ of a nitric acid solution containing $22.13 \mathrm{mg} / \mathrm{mL}$ uranium, $1.12 \mathrm{mg} / \mathrm{mL}$ plutonium and $50.2 \mathrm{mg} / \mathrm{mL}$ neptunium. The solution stirred for 11 days at ambient temperature. Personnel then pipetted $1.00 \mathrm{~mL}$ of $\mathrm{Sr}-85$ in hydrochloric acid $(0.28 \mathrm{mCi} / \mathrm{mL})$ into the solution and stirred it overnight before filtering it through a $0.45-\mu \mathrm{m}$ pore size, disposable (cellulose nitrate) membrane filter. Researches next pipetted $0.10 \mathrm{~mL}$ of $\mathrm{Sr}-85$ in hydrochloric acid $(0.28 \mathrm{mCi} / \mathrm{mL})$ into the solution and stirred overnight followed by filtration through a $0.45-\mu \mathrm{m}$ pore size, disposable (cellulose nitrate) membrane filter. We stored the final solution in clean $8 \mathrm{~L}$ PE carboy labeled as " $7.5 \mathrm{M}$ Low". Personnel used distilled, deionized water to dilute the "7.5 M Low" stock solution to yield $2.75 \mathrm{~L}$ of "6.0 M Low" and $1.5 \mathrm{~L}$ of "4.5 M Low" stock.

\section{Adsorption Tests}

All tests used one of the six salt solutions prepared above, MST manufactured by Optima Chemical Company, Inc. (Batch \#33180), reagent grade sodium tetraphenylborate (Aldrich, Lot \# 01608AQ) and a synthetic Purex sludge prepared by M. J. Barnes (see Table II). Researchers placed $100 \mathrm{~mL}$ of the appropriate salt solution into a capped, high-density PE bottle and held the solution overnight at temperature (i.e., 25,45 , or $65^{\circ} \mathrm{C}$ ). The following day, personnel added the measured quantities of MST, NaTPB and sludge solids to the appropriate test bottle. They then capped the bottles and agitated those bottles in the Lab Line waterbath. Tests were run at the three temperatures in the following order; $25^{\circ} \mathrm{C}, 65^{\circ} \mathrm{C}$ and $45^{\circ} \mathrm{C}$. Water loss from the Lab Line waterbath during the $65^{\circ} \mathrm{C}$ test required the use of a continuous slow water addition (of approximately $2 \mathrm{~mL} / \mathrm{min}$ ) to maintain the liquid level at or above the level in the sample bottles. 
Temperature control occurred either by inserting the test bottles into a Fisher Isotemp Model \# 205 waterbath (unagitated) or a Lab Line (Cole-Parmer Catalog \#E-01290-20) waterbath (agitated). Figure 1 presents photographs of test bottles in the two waterbaths. Researchers selected bottle locations within the waterbath at random and changed bottle positions for each temperature.

Personnel recorded waterbath temperatures using a thermistor thermometer (Omega ${ }^{\circledR}$ Model \# 5831) with thermistor probes (Omega ${ }^{\circledR}$ Model \#OL-703) inserted into each waterbath. Figures 2-4 contain plots of the temperature recordings during each test period. Table III provides calculated average and mean temperatures for each test and waterbath.

Table II. Concentration of Major Metal Components in Synthetic Purex Sludge

$\begin{array}{cc}\frac{\mathrm{Wetal}}{\mathrm{Fe}} & \frac{\mathrm{Wt} \%^{\mathrm{a}}}{28.8} \\ \mathrm{Mn} & 5.9 \\ \mathrm{Al} & 4.8 \\ \mathrm{Ni} & 2.5 \\ \mathrm{Zr} & 2.5 \\ \mathrm{~Pb} & 0.3 \\ \mathrm{Cr} & 0.2 \\ \mathrm{Zn} & 0.2 \\ \mathrm{Mg} & 0.1\end{array}$

${ }^{a}$ Weight percent on dry sludge basis. Composition based on values reported in "Revision of Batch 1 Sludge Composition for Integrated Cold Run in the Defense Waste Processing Facility," N. D. Hudson, WSRC-TR-95-0079, February 16, 1995.

Table III. Average and Mean Waterbath Temperatures

\begin{tabular}{|c|c|c|c|c|}
\hline \multirow{3}{*}{$\begin{array}{l}\text { Target Test } \\
\text { Temperature }\end{array}$} & \multicolumn{4}{|c|}{ Temperature $\left({ }^{\circ} \mathrm{C}\right)$} \\
\hline & Isot & & Lab & \\
\hline & Average $^{1}$ & Mean & Average & Mean \\
\hline $25^{\circ} \mathrm{C}$ & $\begin{array}{l}25.18 \\
(0.25)\end{array}$ & 25.16 & $\begin{array}{l}25.48 \\
(0.22)\end{array}$ & 25.43 \\
\hline $45^{\circ} \mathrm{C}$ & $\begin{array}{l}45.41 \\
(0.56)\end{array}$ & 45.37 & $\begin{array}{l}45.38 \\
(0.80)\end{array}$ & 45.66 \\
\hline $65^{\circ} \mathrm{C}$ & $\begin{array}{l}65.06 \\
(0.63)\end{array}$ & 65.19 & $\begin{array}{l}64.12 \\
(1.33)\end{array}$ & 64. \\
\hline
\end{tabular}


Figure 1A. Lab Line Orbital Shaker Waterbath

Front View

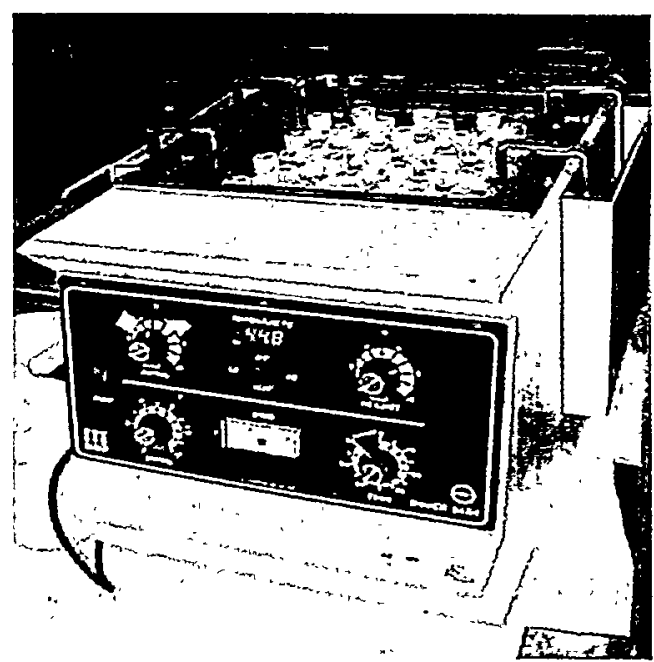

Top View

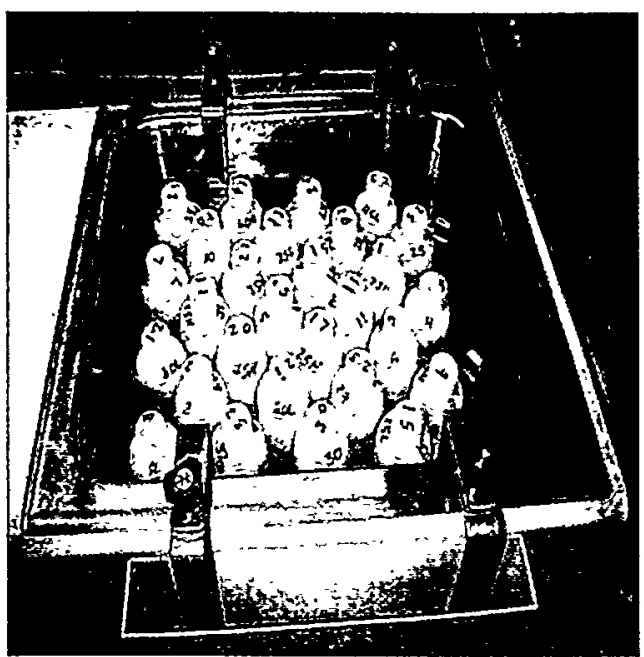

Figure 1B. Isotemp Waterbath

Front View

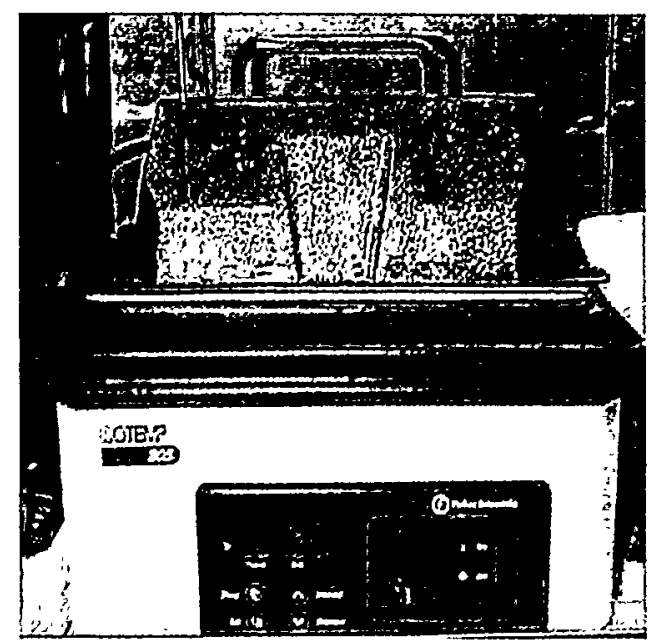

Top View

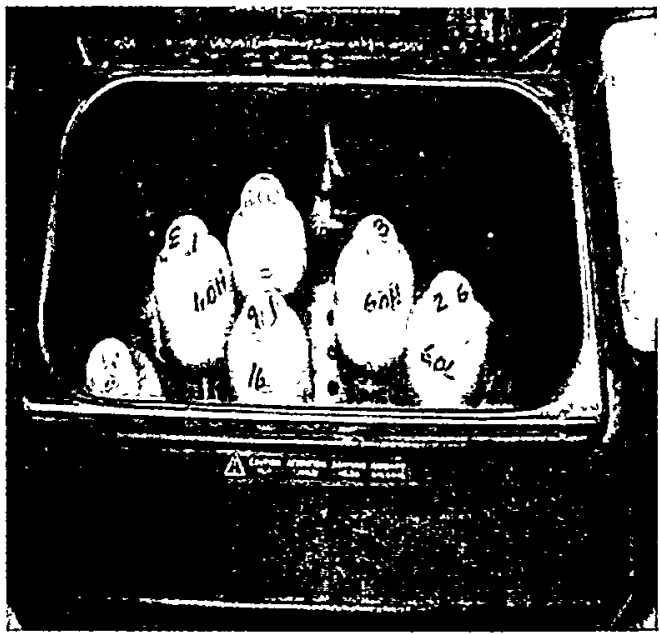

Sampling of each test bottle occurred after approximately 2, 4, 8, 24, 48, 96 and 168 hours in the tests at 45 and $65^{\circ} \mathrm{C}$ tests. Collection of the samples for the $25^{\circ} \mathrm{C}$ test occurred at those times as well as at 240 hours. The sampling method consisted of removing the test bottle from the waterbath, briskly shaking for about 30 seconds to provide a homogeneous suspension, and pulling approximately $5 \mathrm{~mL}$ of the suspension into a disposable plastic syringe. The researcher then inserted a $0.45 \mu \mathrm{m}$ disk (nylon membrane) filter onto the syringe, collected about $4 \mathrm{~mL}$ of filtrate into a clean PE sample bottle and pipetted $3 \mathrm{~mL}$ of the resulting filtrate into a glass vial containing $3 \mathrm{~mL}$ of $5 \mathrm{M}$ nitric acid. 
Personnel discarded all excess filtrate. Personnel recapped the test bottle and returned it to the waterbath. The total time outside of the waterbath for sampling did not exceed 2 minutes. A white precipitate formed immediately upon mixing of the sample with the nitric acid. Personnel then capped the glass sample vial, gently agitated the contents, and allowed it to stand at ambient laboratory temperature until all solids dissolved.

The Analytical Development Section of SRTC performed all radiochemical analyses. Strontium-85 and neptunium-237 activity determinations occurred by gamma pulse height spectroscopy. Concentration measurements of strontium-88, neptunium-237, uranium-238, plutonium-239 and plutonium-240 measurements used ICP-MS (Inductively Coupled Plasma Mass Spectroscopy) analysis. Plutonium-239/240 activity determination relied on alpha spectroscopy after chemical separation from $\mathrm{Np}-237$.

An additional set of five tests evaluated the effect of more vigorous mixing on the adsorption extent and rate. Table IV lists specific conditions for each test. The speed of the magnetic stirrer $(700 \mathrm{rpm})$ provided a visible vortex and kept all of the MST solids suspended throughout the solution. A speed of $200 \mathrm{rpm}$ in the orbital mixer agitated the solution, but did not suspend the majority of the MST solids.

These five tests occurred at ambient laboratory temperature. Over the course of these tests, the ambient laboratory temperature averaged $17.62 \pm 0.26^{\circ} \mathrm{C}$ and the water temperature in the shaking waterbath averaged $20.78 \pm 0.19^{\circ} \mathrm{C}$. Sampling occurred at about $0.3,0.5,0.75,1.0,1.5,2.0,4.0,7.0$ and 24 hours. The authors decided to sample earlier and more frequently in these tests based on the test results from the above experimental design.

Table IV. Test Conditions in Additional Mixing Tests

\begin{tabular}{|c|c|c|c|c|}
\hline Test\# & Mixing Type $^{\mathrm{a}}$ & Speed (rpm) & Solution $^{\mathrm{b}}$ & {$[\mathrm{MST}](\mathrm{g} / \mathrm{L})$} \\
\hline$\overline{M 1}$ & magnetic & 700 & $4.5 \mathrm{M} \mathrm{Hi}$ & 1.74 \\
\hline $\mathrm{O} 1$ & orbital & 200 & $4.5 \mathrm{M} \mathrm{Hi}$ & 1.56 \\
\hline M3 & magnetic & 700 & 4.5M Lo & 0.0 \\
\hline M4 & magnetic & 700 & $4.5 \mathrm{M} \mathrm{Lo}$ & 1.75 \\
\hline $\mathrm{O} 2$ & orbital & 200 & $4.5 \mathrm{M}$ Lo & 3.51 \\
\hline
\end{tabular}

a magnetic $=$ Barnstead/Thermolyne (Model SP73235) 4-place magnetic stirrer orbital = Lab Line (Cole-Parmer Catalog \#E-01290-20) shaking waterbath

${ }^{\mathrm{b}} 4.5 \mathrm{M}$ Hi represents the high activity $4.5 \mathrm{M} \mathrm{Na}^{+} \mathrm{M}$ salt solution $4.5 \mathrm{M}$ Lo represents the low activity $4.5 \mathrm{M} \mathrm{Na}^{+} \mathrm{M}$ salt solution 
Figure 2. Waterbath Temperature Profiles at $25^{\circ} \mathrm{C}$

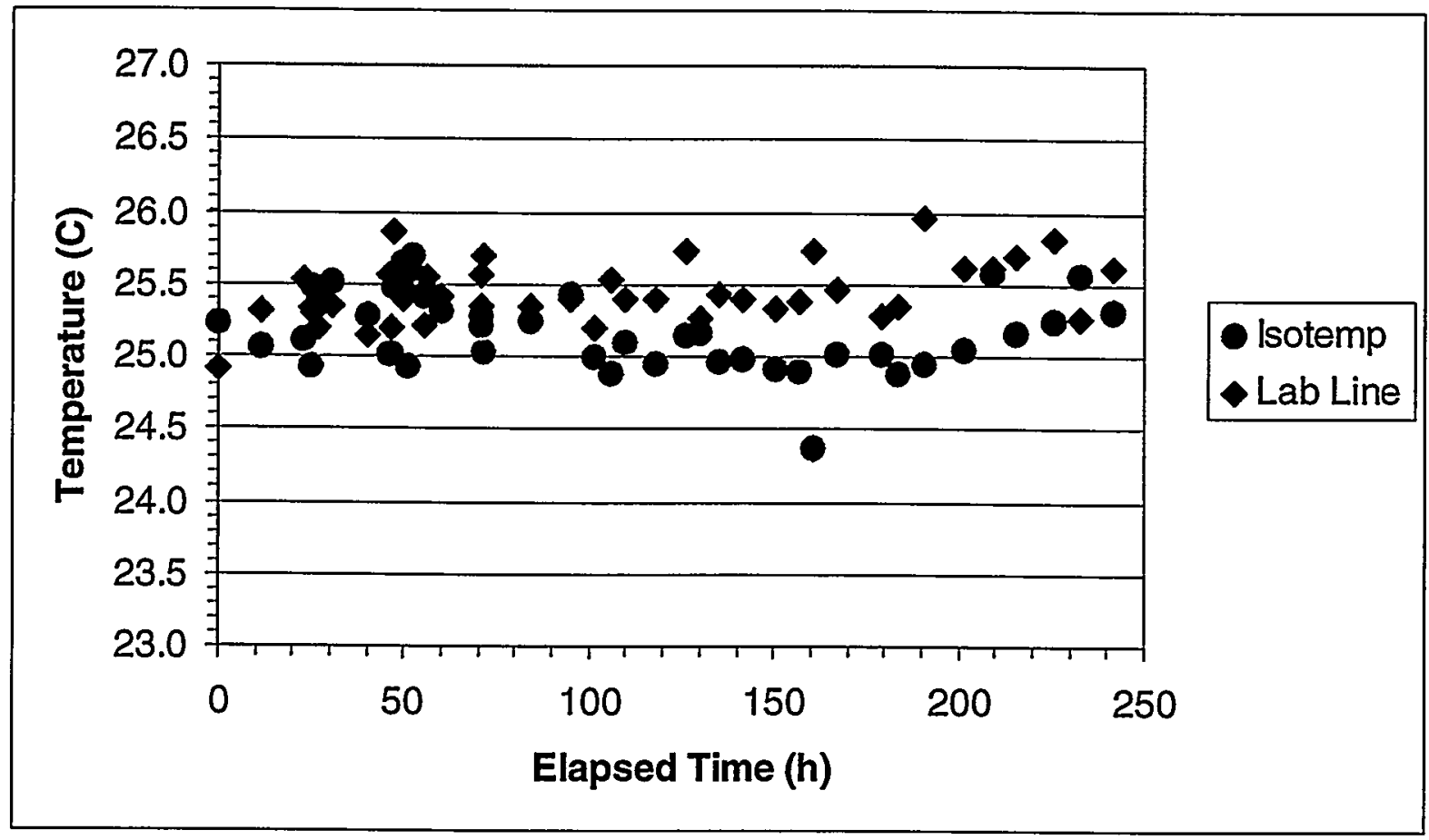

Figure 3. Waterbath Temperature Profiles at $45^{\circ} \mathrm{C}$

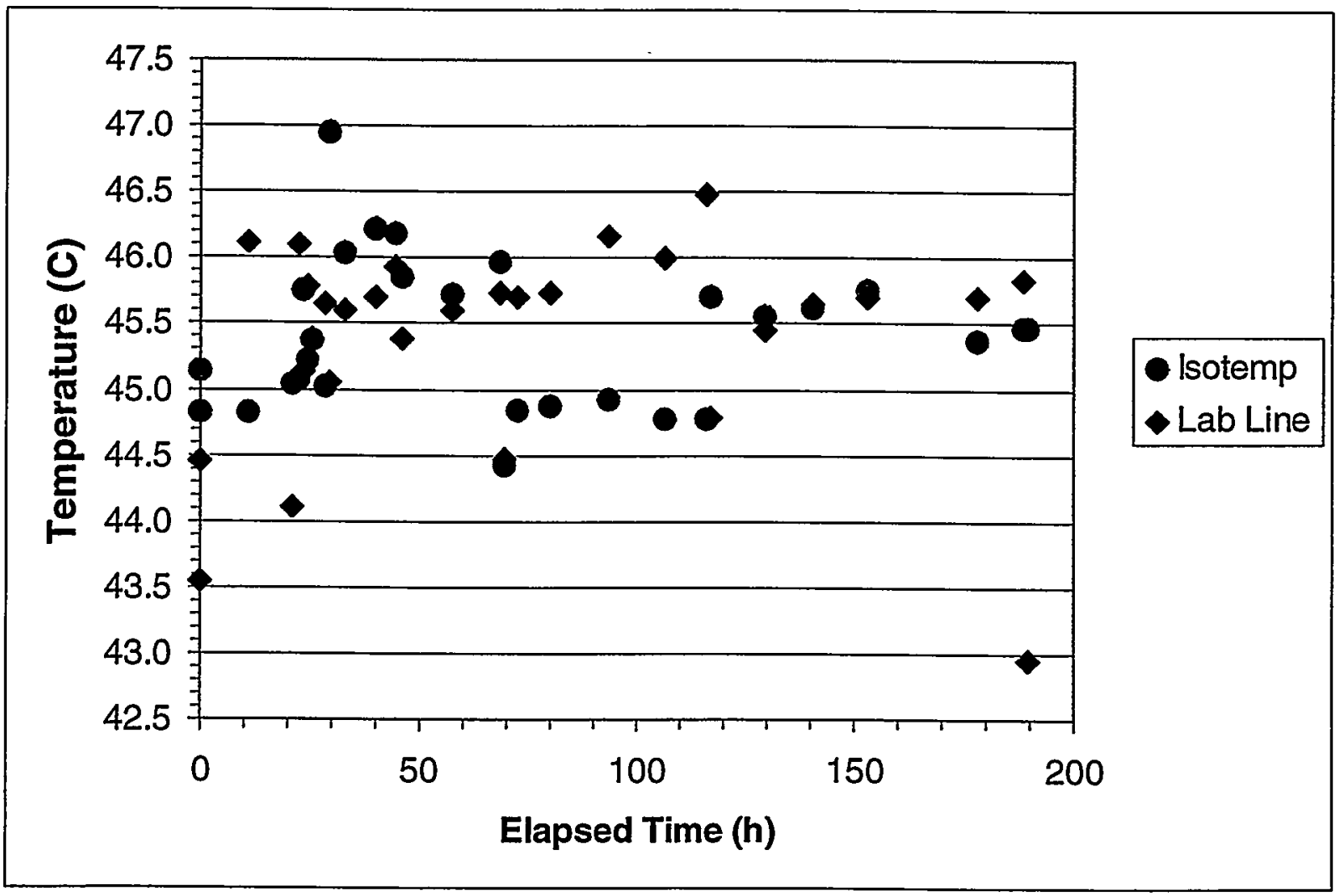




\section{Figure 4. Waterbath Temperature Profiles at $65^{\circ} \mathrm{C}$}

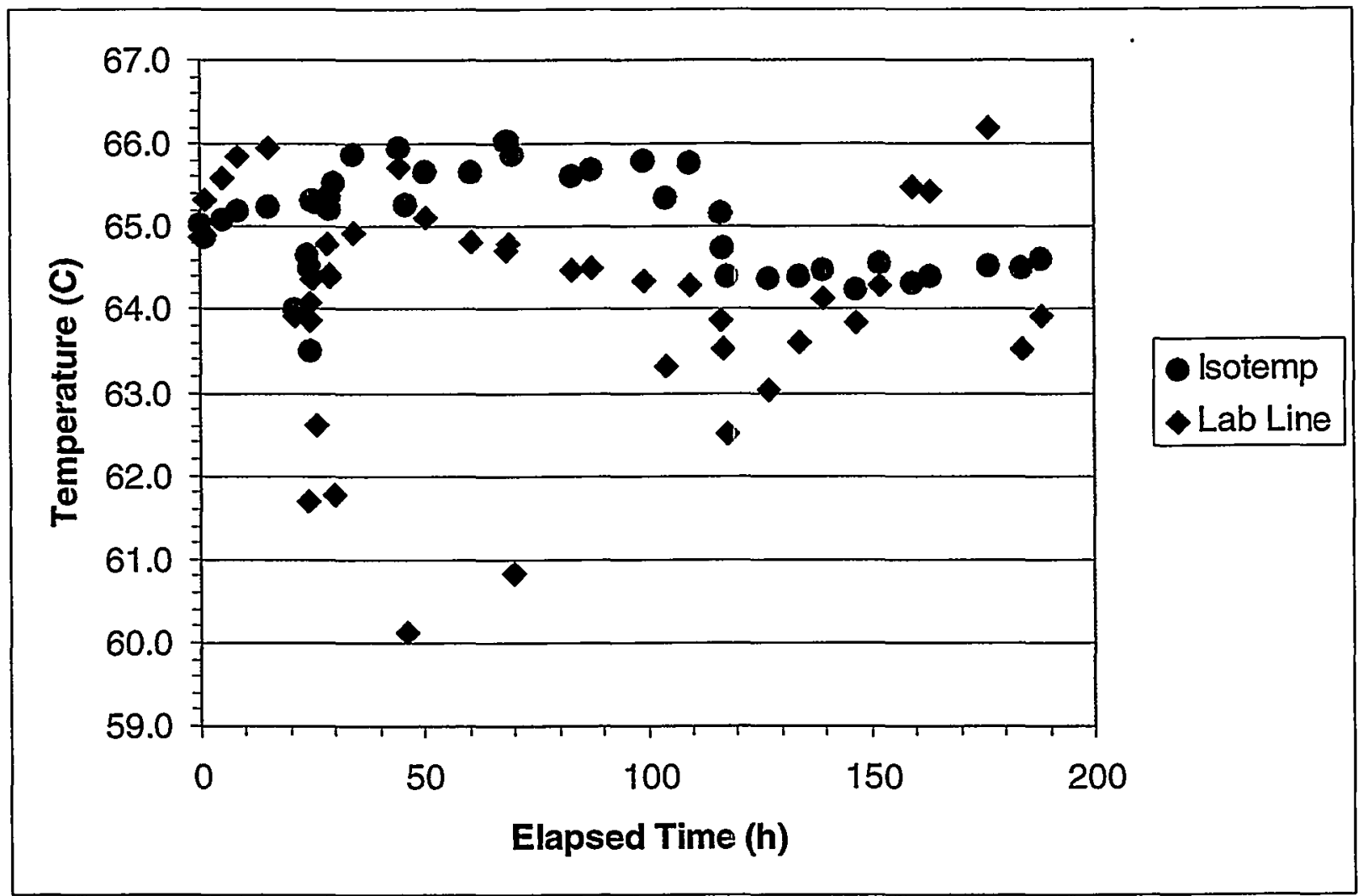

\section{Results and Discussion}

\section{Experimental Design}

The statistically designed set of tests included the following parameters: temperature, sodium ion concentration, MST concentration, initial concentrations (of strontium, neptunium, uranium and plutonium), mixing, and the presence of sodium tetraphenylborate and sludge solids. Table $\mathrm{V}$ provides a list of the targeted range of values for each parameter. The target sorbate concentrations were selected based on solubility considerations (i.e., the high value is at or near the solubility limit for the sorbate). For strontium and neptunium, the solubility limits are much greater than expected concentrations in the feed solutions to the salt processing facility [11]. Because of the high neptunium and uranium concentrations, the upper MST concentration was set at $2.0 \mathrm{~g} / \mathrm{L}$.

The initial strontium and plutonium concentrations were significantly lower than the target values. Total strontium concentration initiated at about $0.006 \mathrm{mg} / \mathrm{L}$ for the low activity solutions and about $0.080 \mathrm{mg} / \mathrm{L}$ for the high activity solutions. Total plutonium concentration initiated from about 0.001 to $0.006 \mathrm{mg} / \mathrm{L}$ for the low activity solutions and about $0.2 \mathrm{mg} / \mathrm{L}$ for the high activity solutions. Appendices 1-3 provide the initial concentrations for each test. 
Table V. Targeted Parameter Values

\begin{tabular}{|c|c|c|c|}
\hline Parameter & Low & Mid & High \\
\hline Temperature & $\overline{25^{\circ} \mathrm{C}}$ & $45^{\circ} \mathrm{C}$ & $65^{\circ} \mathrm{C}$ \\
\hline Sodium Concentration & $4.5 \mathrm{M}$ & $6.0 \mathrm{M}$ & $7.5 \mathrm{M}$ \\
\hline MST Concentration ${ }^{1}$ & $0.2 \mathrm{~g} / \mathrm{L}$ & $1.1 \mathrm{~g} / \mathrm{L}$ & $2.0 \mathrm{~g} / \mathrm{L}$ \\
\hline Mixing & no & & yes \\
\hline Strontium & $0.1 \mathrm{mg} / \mathrm{L}$ & & $1.0 \mathrm{mg} / \mathrm{L}$ \\
\hline Neptunium & $4.0 \mathrm{mg} / \mathrm{L}$ & & $40 \mathrm{mg} / \mathrm{L}$ \\
\hline Uranium & $1.0 \mathrm{mg} / \mathrm{L}$ & & $10 \mathrm{mg} / \mathrm{L}$ \\
\hline Plutonium & $0.1 \mathrm{mg} / \mathrm{L}$ & & $1.0 \mathrm{mg} / \mathrm{L}$ \\
\hline Sodium Tetraphenylborate & $0.0 \mathrm{mg} / \mathrm{L}$ & & $400 \mathrm{mg} / \mathrm{L}$ \\
\hline Sludge Solids & $0.0 \mathrm{mg} / \mathrm{L}$ & & $400 \mathrm{mg} / \mathrm{L}$ \\
\hline
\end{tabular}

Table VI provides an outline of the statistical experimental design. The table differs from that originally developed to reflect a lower temperature [4]. Due to constraints on the number of bottles that can fit in the agitated waterbath, researchers did not replicate the tests with sludge and NaTPB solids. 


\section{Table VI. Statistical Design Test Outline}

\begin{tabular}{|c|c|c|c|c|c|c|c|c|c|c|c|c|c|}
\hline \multirow{2}{*}{$\begin{array}{l}\text { Experimental } \\
\text { Notes }\end{array}$} & \multicolumn{12}{|c|}{ Actinide ( $\mathrm{Pu}, \mathrm{U}$, and $\mathrm{Np})$ and Sr Loading } & \multirow[b]{3}{*}{$\operatorname{Rep}$} \\
\hline & \multicolumn{6}{|c|}{ - } & \multicolumn{6}{|c|}{ High } & \\
\hline & $\begin{array}{c}\text { Temp } \\
{ }^{\circ} \mathrm{C}\end{array}$ & $\begin{array}{c}\text { MST } \\
g / \mathbf{L}\end{array}$ & $\begin{array}{c}\mathrm{Nat} \\
\mathrm{M}\end{array}$ & Mixing & TPB & Sludge & $\begin{array}{c}\text { Temp } \\
{ }^{\circ} \mathrm{C}\end{array}$ & $\begin{array}{c}\text { MST } \\
g / L\end{array}$ & Nat & Mixing & TPB & Sludge & \\
\hline Baseline & 25 & 0 & 6 & Yes & No & No & 25 & 0 & 6 & Yes & No & No & Yes \\
\hline \multirow[t]{3}{*}{ Special } & 25 & 1.1 & 6 & Yes & Yes & No & 25 & 1.1 & 6 & Yes & Yes & No & No \\
\hline & 25 & 1.1 & 6 & Yes & No & Yes & 25 & 1.1 & 6 & Yes & No & Yes & No \\
\hline & 25 & 1.1 & 6 & No & No & No & 25 & 1.1 & 6 & No & No & No & Yes \\
\hline \multirow[t]{5}{*}{ Designed } & 25 & 1.1 & 6 & Yes & No & No & 25 & 1.1 & 6 & Yes & No & No & Yes \\
\hline & 25 & 0.2 & 4.5 & Yes & No & No & 25 & 0.2 & 4.5 & Yes & No & No & Yes \\
\hline & 25 & 0.2 & 7.5 & Yes & No & No & 25 & 0.2 & 7.5 & Yes & No & No & Yes \\
\hline & 25 & 1 & 4.5 & Yes & No & No & 25 & 1 & 4.5 & Yes & No & No & Yes \\
\hline & 25 & 1 & 7.5 & Yes & No & No & 25 & 1 & 7.5 & Yes & No & No & Yes \\
\hline Baseline & 70 & 0 & 6 & Yes & No & No & 70 & 0 & 6 & Yes & No & No & $\overline{\text { Yes }}$ \\
\hline \multirow[t]{3}{*}{ Special } & 70 & 1.1 & 6 & Yes & Yes & No & 70 & 1.1 & 6 & Yes & Yes & No & No \\
\hline & 70 & 1.1 & 6 & Yes & No & Yes & 70 & 1.1 & 6 & Yes & No & Yes & No \\
\hline & 70 & 1.1 & 6 & No & No & No & 70 & 1.1 & 6 & No & No & No & Yes \\
\hline \multirow[t]{5}{*}{ Designed } & 70 & 1.1 & 6 & Yes & No & No & 70 & 1.1 & 6 & Yes & No & No & Yes \\
\hline & 70 & 0.2 & 4.5 & Yes & No & No & 70 & 0.2 & 4.5 & Yes & No & No & Yes \\
\hline & 70 & 0.2 & 7.5 & Yes & No & No & 70 & 0.2 & 7.5 & Yes & No & No & Yes \\
\hline & 70 & 2 & 4.5 & Yes & No & No & 70 & 2 & 4.5 & Yes & No & No & Yes \\
\hline & 70 & 2 & 7.5 & Yes & No & No & 70 & 2 & 7.5 & Yes & No & No & Yes \\
\hline Baseline & 45 & 0 & 6 & Yes & No & No & 45 & 0 & 6 & Yes & No & No & $\overline{\text { Yes }}$ \\
\hline \multirow[t]{3}{*}{ Special } & 45 & 1.1 & 6 & Yes & Yes & No & 45 & 1.1 & 6 & Yes & Yes & No & No \\
\hline & 45 & 1.1 & 6 & Yes & No & Yes & 45 & 1.1 & 6 & Yes & No & Yes & No \\
\hline & 45 & 1.1 & 6 & No & No & No & 45 & 1.1 & 6 & No & No & No & Yes \\
\hline \multirow[t]{10}{*}{ Designed } & 45 & 0.2 & 6 & Yes & No & No & 45 & 0.2 & 6 & Yes & No & No & No \\
\hline & 45 & 2 & 6 & Yes & No & No & 45 & 2 & 6 & Yes & No & No & No \\
\hline & 45 & 1.1 & 4.5 & Yes & No & No & 45 & 1.1 & 4.5 & Yes & No & No & No \\
\hline & 45 & 1.1 & 7.5 & Yes & No & No & 45 & 1.1 & 7.5 & Yes & No & No & No \\
\hline & 45 & 1.1 & 6 & Yes & No & No & 45 & 1.1 & 6 & Yes & No & No & No \\
\hline & 45 & 1.1 & 6 & Yes & No & No & 45 & 1.1 & 6 & Yes & No & No & No \\
\hline & 45 & 1.1 & 6 & Yes & No & No & 45 & 1.1 & 6 & Yes & No & No & No \\
\hline & 45 & 1.1 & 6 & Yes & No & No & 45 & 1.1 & 6 & Yes & No & No & No \\
\hline & 45 & 1.1 & 6 & Yes & No & No & 45 & 1.1 & 6 & Yes & No & No & No \\
\hline & 45 & 1.1 & 6 & Yes & No & No & 45 & 1.1 & 6 & Yes & No & No & No \\
\hline
\end{tabular}

\section{Control Samples}

Each test set consisted of two bottles containing the low activity and two bottles containing the high activity $6.0 \mathrm{M} \mathrm{Na}^{+}$salt solutions with no added MST. These tests serve as control samples to correct for removal of sorbates by sorption onto the bottle walls, the filter or by precipitation. Appendix 1 provides the average sorbate concentration versus time data at each temperature for the control samples. Appendices 2-5 show plots of the concentration versus time data for each sorbate and temperature.

The high activity solutions exhibited relative standard deviations of the sorbate concentrations with time of less than $10 \%$ and, therefore, were not corrected. The low activity solutions exhibited relative standard deviations of greater than $10 \%$ in the strontium, plutonium and neptunium concentrations. Correction factors consisted of the ratio of the initial concentration to that at the time of sampling. These correction factors were applied to the other concentration results for tests with added MST. As a result of this correction factor, some graphs of the sorbate concentration versus time exhibit an 
initial decrease and then an increase in the sorbate concentration. This occurs more often when the measured concentration approaches the analytical detection limit of the sorbate.

\section{Removal Efficiency Criteria}

The appropriate isotopic limit for decontaminated salt solution sent to Z-Area provides the criteria for removal of each radionuclide [5]. Uranium does not have a criterion since the combination of the low specific activity and low solubility of uranium prohibits the decontaminated salt solution from exceeding the total alpha activity of $20 \mathrm{nCi} / \mathrm{g}$. For example, the calculated alpha activity for uranium assuming $100 \%$ U-235 (highest specific activity) is $0.046 \mathrm{nCi} / \mathrm{g}$ at the highest uranium concentration tested $(26 \mathrm{mg} / \mathrm{L})$. The neptunium-237 limit is $0.03 \mathrm{nCi} / \mathrm{g}$ which equals $51-56 \mu \mathrm{g} / \mathrm{L}$ for salt solutions ranging in density from $1.206\left(4.5 \mathrm{M} \mathrm{Na}^{+}\right)$to $1.336 \mathrm{~g} / \mathrm{mL}\left(7.5 \mathrm{M} \mathrm{Na}^{+}\right)$.

The $\mathrm{Sr}-90$ limit for feed solution to Z-Area is $40 \mathrm{nCi} / \mathrm{g}$ [5]. To convert the activity limit to a total strontium mass concentration basis, we set the Sr-90 content at either 45 or 5.2 atomic (at) \%. The higher value derives from the known fission yields of Sr-88 and Sr-90 [6] and correcting for radioactive decay of the $\mathrm{Sr}-90$ (assuming an average waste age of 29 years). The lower value equals that determined in a sample of Tank 51H sludge analyzed at SRTC [7]. The 45 at \% value provides a reasonable upper limit for $\mathrm{Sr}-90$ since impurities in processing chemicals and process water add some amount of non-radioactive strontium into the $\mathrm{HLW}$. This value is not necessarily bounding since the age of the waste processed could be less than 29 years. Table VII provides a list of the strontium limits based on mass concentration.

\section{Table VII. Sr-90 Limits Converted to Total Strontium Mass Limits}

$\frac{\text { Atomic } \% \text { Sr-90 }}{5.2}$

45
Concentration Limit $(\mu \mathrm{g} / \mathrm{L})$

$\frac{@, 4.5 \mathrm{M} \mathrm{Na}^{+}}{6.5} \quad \frac{@ 7.5 \mathrm{M} \mathrm{Na}^{+}}{7.3}$

0.76
0.84

Plutonium-containing wastes originate from the production of weapons grade (WG) plutonium (containing primarily $\mathrm{Pu}-239 / 240$ ) and heat source (HS) plutonium (containing primarily $\mathrm{Pu}-238$ ). ZArea limits the total alpha activity in decontaminated salt solution to $20 \mathrm{nCi} / \mathrm{g}$ [5]. We converted this limit to a mass concentration assuming all of the alpha activity comes from plutonium and that the plutonium has either a WG or HS isotopic distribution $[9,10]$. The resulting mass limit for HS plutonium $(1.6-1.8 \mu \mathrm{g} / \mathrm{L})$ proves much lower than that for WG plutonium $(40-44 \mu \mathrm{g} / \mathrm{L})$ due to the much higher specific activity for $\mathrm{HS} \mathrm{Pu}(14.6 \mathrm{Ci} / \mathrm{g})$ compared to $W \mathrm{G}$ plutonium $(0.60 \mathrm{Ci} / \mathrm{g})$. Table VIII provides the Z-Area limits on a mass concentration basis for the $4.5 \mathrm{M}$ and $7.5 \mathrm{M}$ salt solutions. 


\section{Table VIII. Plutonium Mass Concentration Limits}

\begin{tabular}{|c|c|c|}
\hline \multirow[b]{2}{*}{ Isotopic Distribution } & \multicolumn{2}{|c|}{ Concentration Limit $(\mu \mathrm{g} / \mathrm{L})$} \\
\hline & $@ 4.5 \mathrm{M} \mathrm{Na}^{+}$ & $@ 7.5 \mathrm{M} \mathrm{Na}^{+}$ \\
\hline Weapons Grade Pu & 40 & 44 \\
\hline Heat Source Pu & 1.6 & 1.8 \\
\hline
\end{tabular}

\section{Extent of Strontium Removal}

Plots of strontium concentration versus time exhibit the expected decrease in concentration with increasing time. After a period of time, no further change occurred in the solution concentration indicating the system had attained equilibrium. Figures $5-8$ provide graphs of the strontium concentration versus time at each temperature, at each initial concentration, at the bounding ionic strength concentrations ( 4.5 and $\left.7.5 \mathrm{M} \mathrm{Na}^{+}\right)$and at the lowest MST concentration $(0.2 \mathrm{~g} / \mathrm{L})$. This MST concentration represents the planned average concentration in each of the salt disposition flowsheets [12]. Appendices $9-22$ provide the strontium concentration data for all test conditions including higher sodium ion concentrations and MST concentrations.

The equilibrium strontium concentration was below strontium mass limits for the range of feed isotopics (e.g., 5.2-45 at \%) considered at each temperature and initial strontium concentration for the lower ionic strength solution (Figures 5 and 6). For the higher ionic strength solutions, the final strontium concentration fell below the limit assuming 5.2 at \% Sr-90 in the feed, but failed to meet the limit assuming 45 at \% Sr-90 in the feed (Figures 7 and 8). Thus, concentrated salt solutions having 45 atomic \% Sr-90 need more than $0.2 \mathrm{~g} / \mathrm{L}$ of MST to reach the $\mathrm{Sr}-90$ limit.

\section{Figure 5. Strontium Removal - 4.5 $\mathrm{M} \mathrm{Na}^{+}$, Low Activity, $0.2 \mathrm{~g} / \mathrm{L} \mathrm{MST}$}

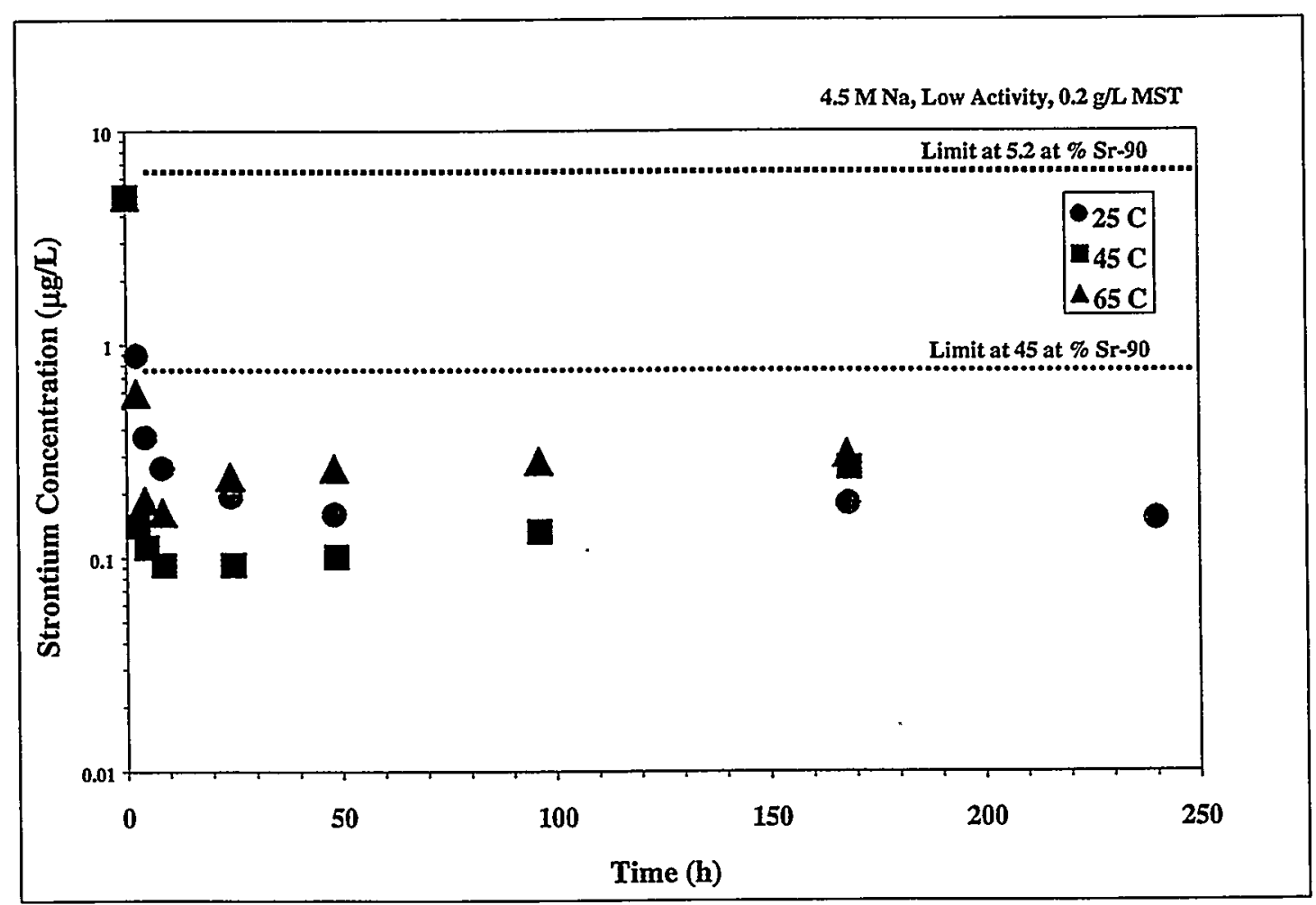


Figure 6. Strontium Removal - 4.5 $\mathrm{M} \mathrm{Na}^{+}$, High Activity, $0.2 \mathrm{~g} / \mathrm{L} \mathrm{MST}$

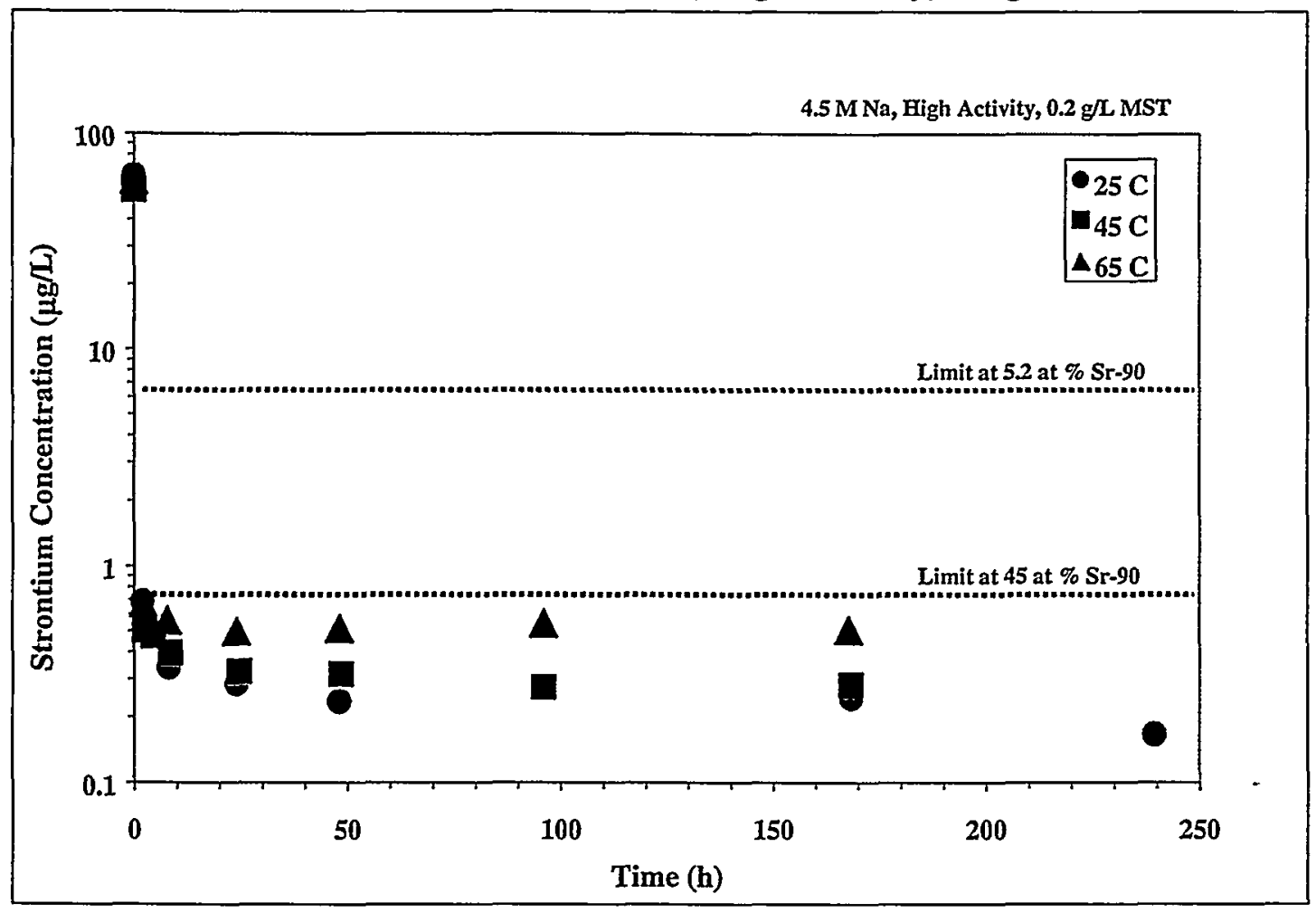

Figure 7. Strontium Removal - 7.5 $\mathrm{M} \mathrm{Na}^{+}$, Low Activity, $0.2 \mathrm{~g} / \mathrm{L}$ MST

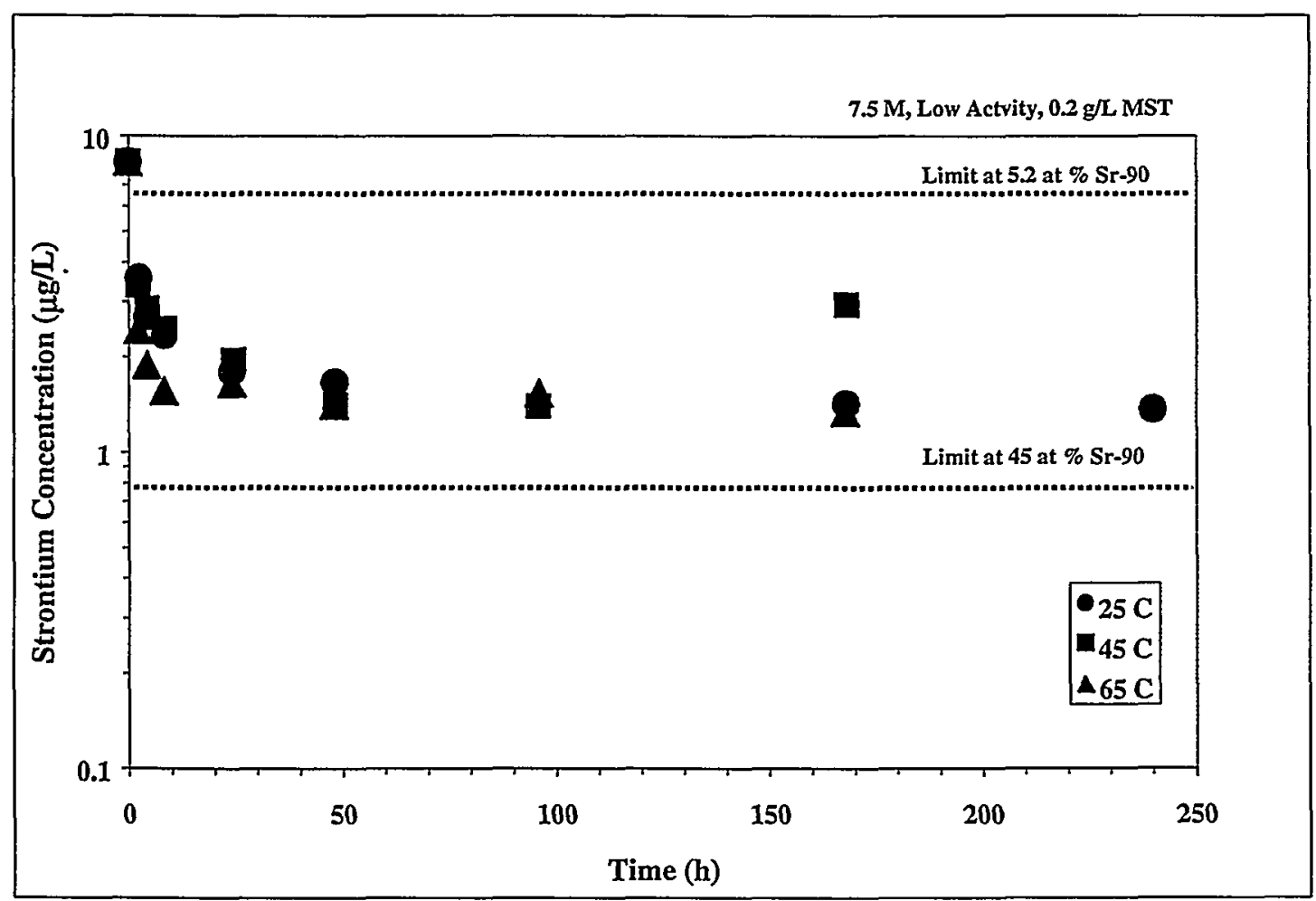


Figure 8. Strontium Removal - 7.5 $\mathrm{M} \mathrm{Na}^{+}$, High Activity, $0.2 \mathrm{~g} / \mathrm{L} \mathrm{MST}$

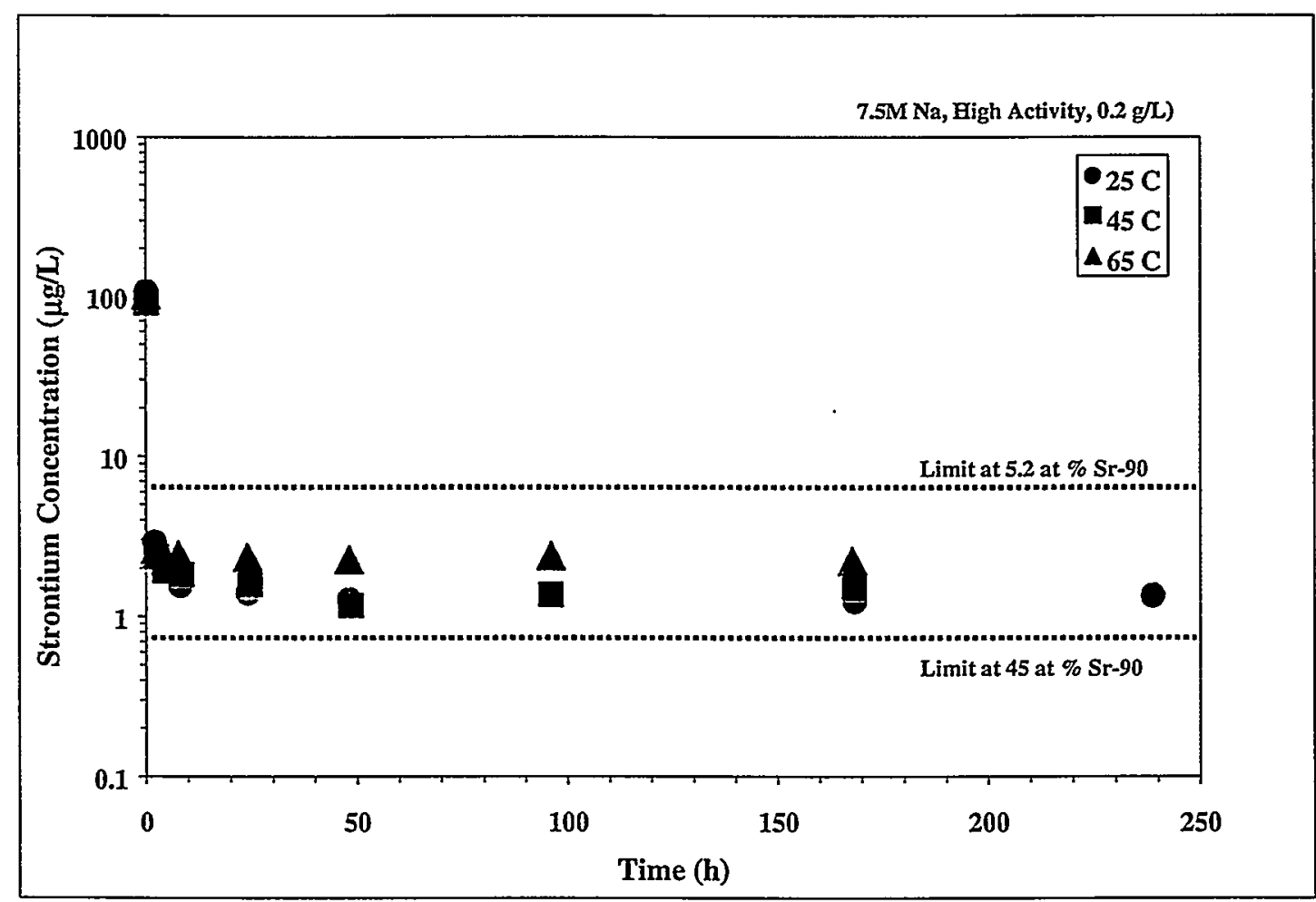

Extent of Plutonium Removal

Assuming WG isotopics for the feed, the final plutonium concentration fell below the limit at each temperature, initial plutonium concentration and each ionic strength (Figures 9 - 12). Appendices 9 22 provide the plutonium concentration data for all test conditions including higher sodium ion concentrations and MST concentrations. For feed containing HS plutonium, the final plutonium concentration in solution met the limit for the lower activity solution (Figure 9) and approached the limit for the higher activity solution (Figure 10). The plutonium concentrations in the higher activity solution reached the lower limit of detection of the analytical method, which nearly equals the mass limit for feed containing HS plutonium. Thus, one cannot conclusively determine if the higher activity solution satisfies the limit with this data. For the high ionic strength feed solution containing HS plutonium, the only test in which the final plutonium concentration did not satisfy the limit was the low activity solution at $65^{\circ} \mathrm{C}$ (Figure 11). Thus, we conclude that the facility would need to control the temperature to lower values or use higher MST concentrations to remove sufficient HS plutonium from solution if present initially at or near the solubility limit for plutonium. 
Figure 9. Plutonium Removal - 4.5 $\mathrm{M} \mathrm{Na}^{+}$, Low Activity, $0.2 \mathrm{~g} / \mathrm{L}$ MST

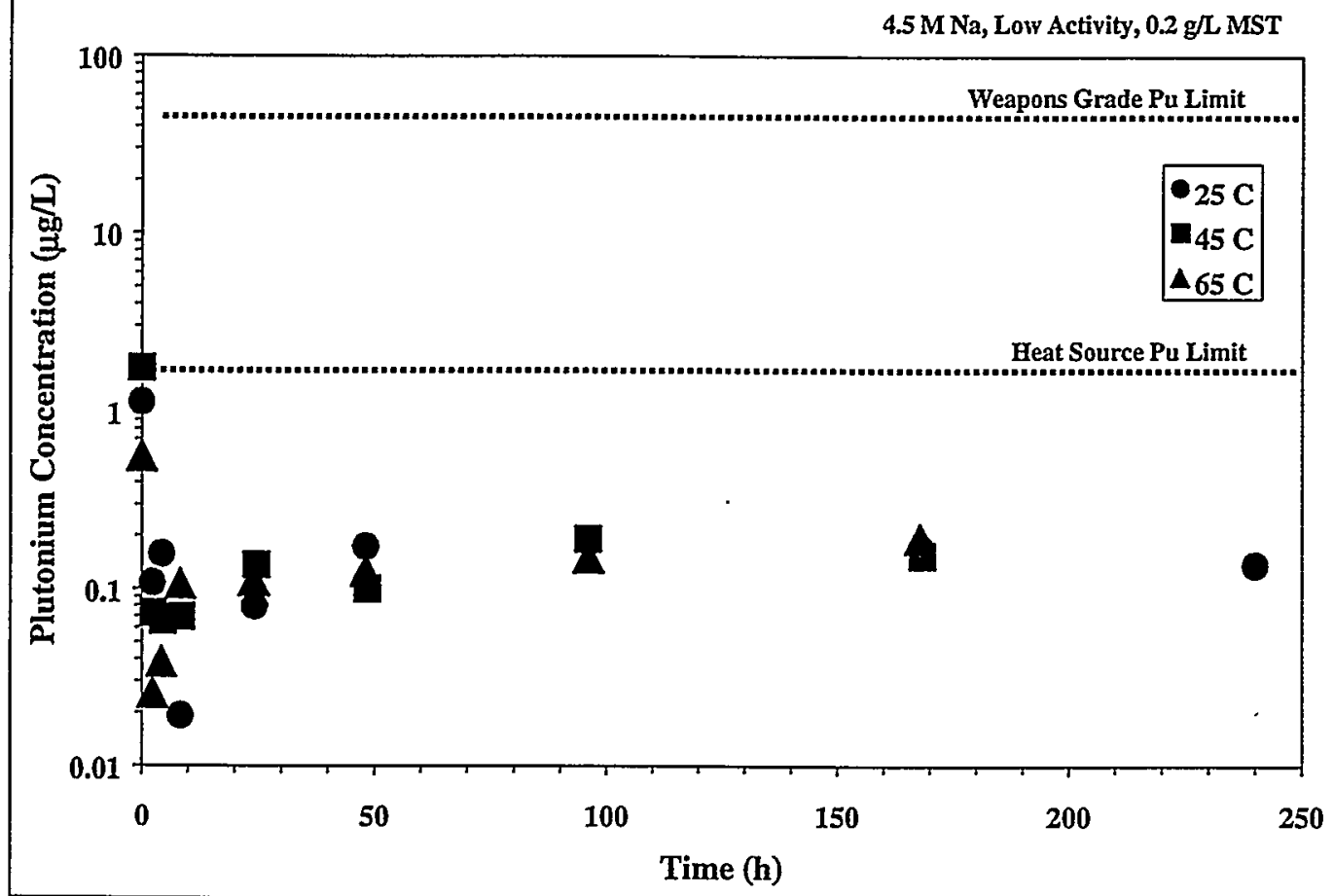

Figure 10. Plutonium Removal - 4.5 $\mathrm{M} \mathrm{Na}^{+}$, High Activity, $0.2 \mathrm{~g} / \mathrm{L} \mathrm{MST}$

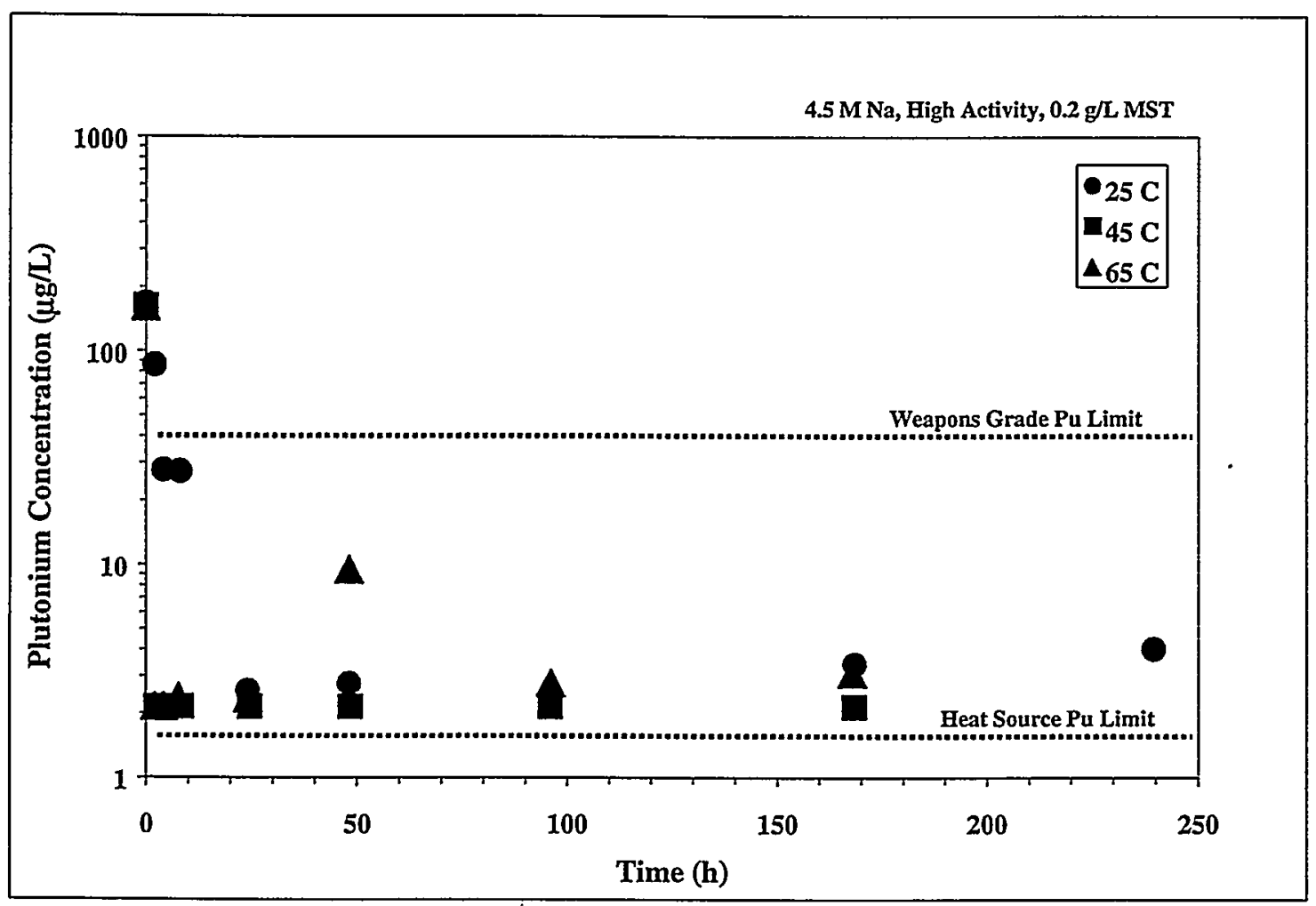


Figure 11. Plutonium Removal - 7.5 $\mathrm{M} \mathrm{Na}^{+}$, Low Activity, $0.2 \mathrm{~g} / \mathrm{L}$ MST

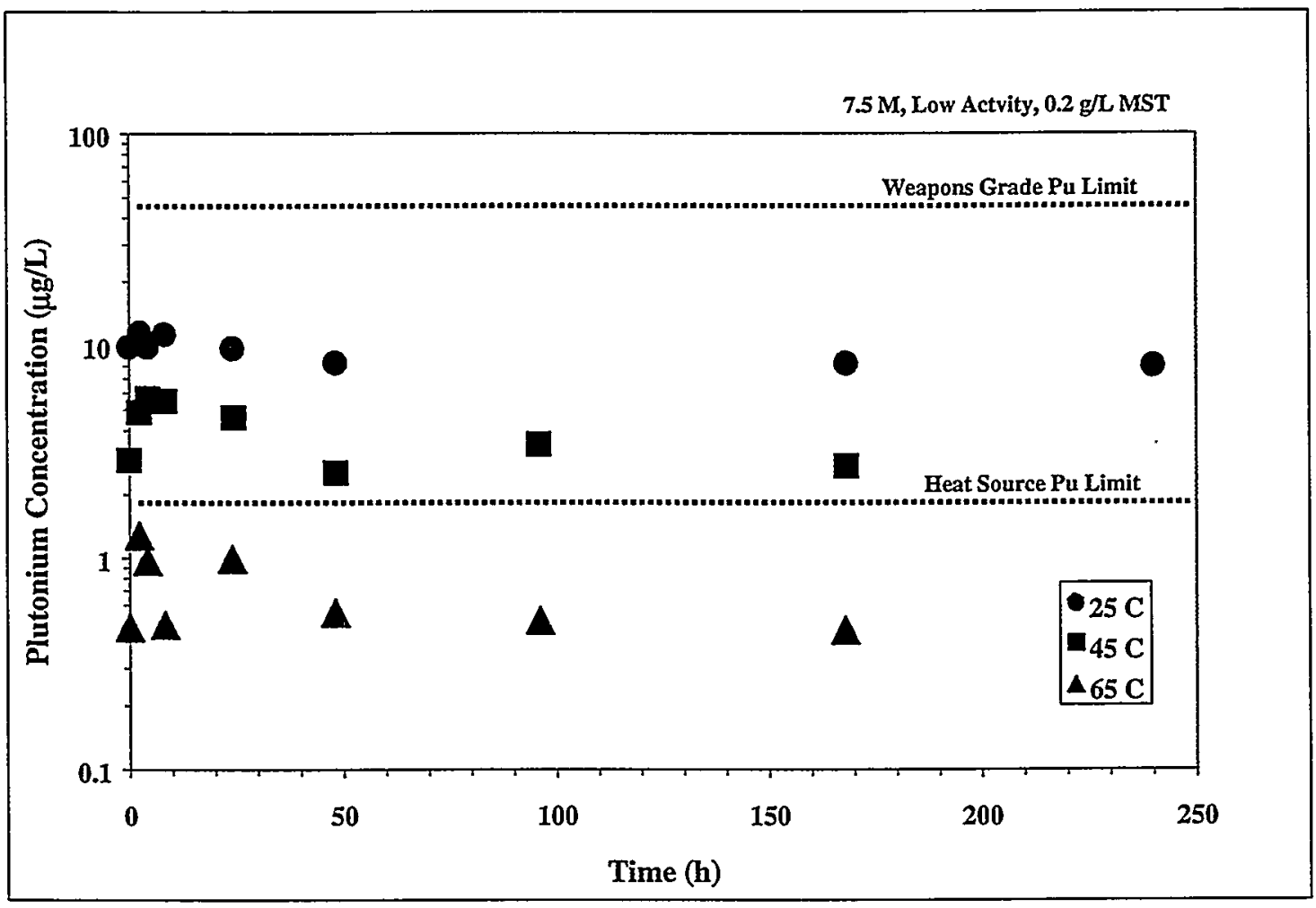

Figure 12. Plutonium Removal - 7.5 $\mathrm{M} \mathrm{Na}^{+}$, High Activity, $0.2 \mathrm{~g} / \mathrm{L}$ MST

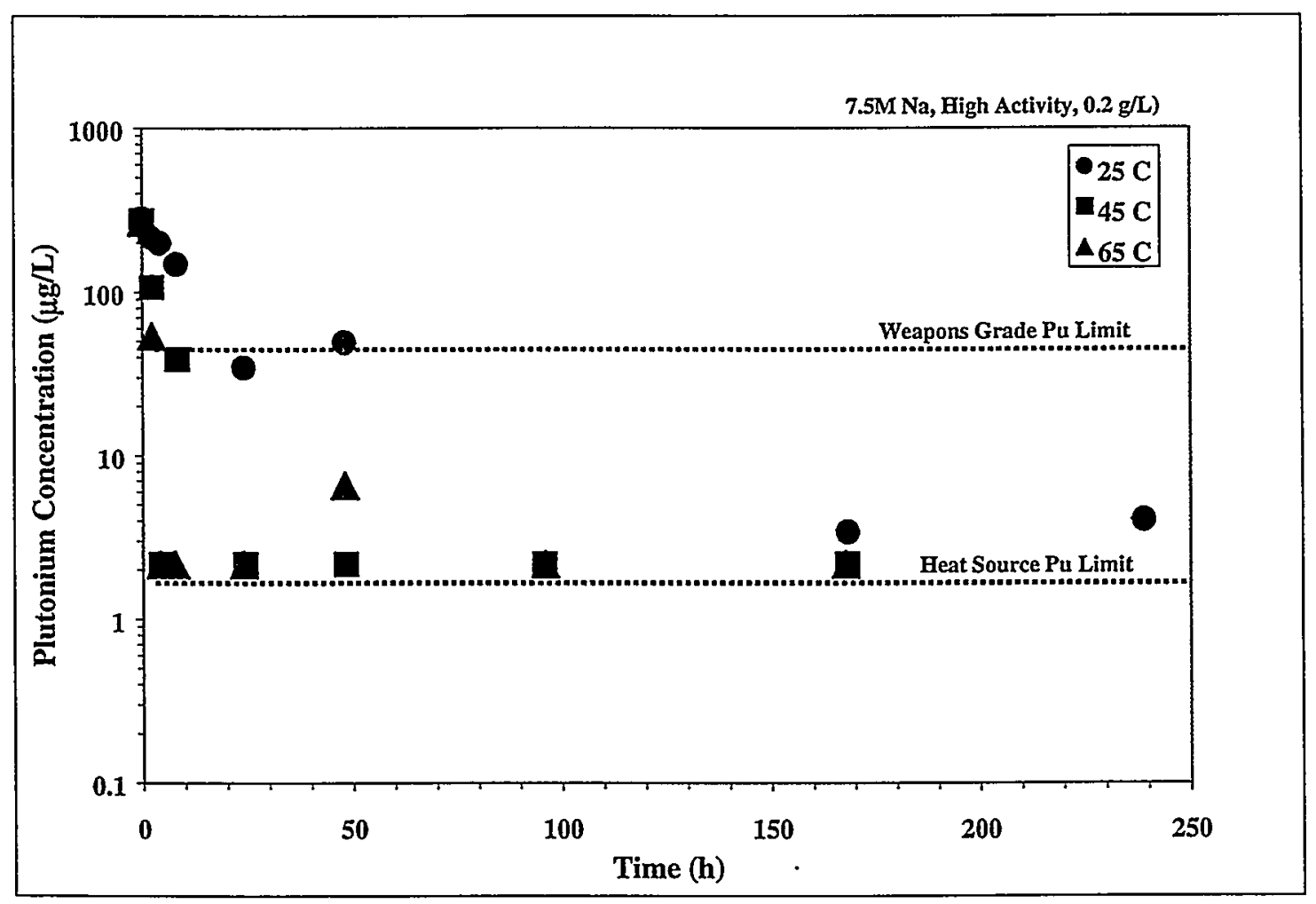




\section{Extent of Uranium Removal}

Figures 13 - 16 provide the graphs of uranium concentrations versus time for the two levels of sodium ion and initial uranium concentrations at a MST concentration of $0.2 \mathrm{~g} / \mathrm{L}$. Appendices $9-22$ provide the uranium concentration data for all test conditions including tests at higher sodium ion concentrations and MST concentrations. Table IX provides a summary of the average equilibrium uranium decontamination factor at each temperature for the various test conditions. The decontamination factor is the ratio of the initial concentration to the equilibrium concentration.

Decontamination factors (DF) remained below 3 ( $<67 \%$ removal) for all solutions treated with 0.2 $\mathrm{g} / \mathrm{L}$ MST. Greater than $93 \%$ removal of uranium occurred in the low activity solutions when the MST concentration increased to $\geq 1.1 \mathrm{~g} / \mathrm{L}$. Uranium removal remained fairly low for all of the high activity solutions and MST concentrations. An increase in the MST concentration by a factor of 10 did not result in a similar increase in the DF. This result suggests that other sorbates are successfully competing with uranium for MST sites.

Table IX. Average Equilibrium Uranium Decontamination Factors

\begin{tabular}{|c|c|c|c|c|c|c|}
\hline \multicolumn{4}{|c|}{ Test Conditions } & \multicolumn{3}{|c|}{ Average Decontamination Factor } \\
\hline$\left[\mathrm{Na}^{+}\right]$ & [MST] & Solution & Other & $25^{\circ} \mathrm{C}$ & $45^{\circ} \mathrm{C}$ & $65^{\circ} \mathrm{C}$ \\
\hline 4.5 & 0.2 & low & $\overline{\text { mixed }}$ & 2.48 & $\overline{2.59}$ & 2.56 \\
\hline 4.5 & 2.0 & low & mixed & $\geq 131$ & $\geq 138$ & $>690$ \\
\hline 6.0 & 1.1 & low & mixed & 24.4 & 22.9 & 15.9 \\
\hline 6.0 & 1.1 & low & unmixed & 21.8 & 10.0 & 17.9 \\
\hline 6.0 & 1.1 & low & NaTPB & 23.0 & 20.6 & 15.1 \\
\hline 6.0 & 1.1 & low & sludge & 24.0 & 19.4 & 24.6 \\
\hline 7.5 & 0.2 & low & mixed & 1.39 & 1.68 & 1.74 \\
\hline 7,5 & 2.0 & low & mixed & 17.3 & 27.4 & 21.1 \\
\hline 4.5 & 0.2 & high & mixed & 1.24 & 1.25 & 1.36 \\
\hline 4.5 & 2.0 & high & mixed & 7.83 & 13.0 & 9.94 \\
\hline 6.0 & 1.1 & high & mixed & 2.74 & 2.94 & 2.83 \\
\hline 6.0 & 1.1 & high & unmixed & 2.45 & 2.80 & 2.73 \\
\hline 6.0 & 1.1 & high & NaTPB & 2.71 & 2.76 & 2.90 \\
\hline 6.0 & 1.1 & high & sludge & 2.15 & 2.43 & 2.34 \\
\hline 7.5 & 0.2 & high & mixed & 1.72 & 1.53 & 1.58 \\
\hline 7.5 & 2.0 & high & mixed & 5.06 & 6.54 & 4.48 \\
\hline
\end{tabular}


Figure 13. Uranium Removal - 4.5 $\mathrm{M} \mathrm{Na}^{+}$, Low Activity, $0.2 \mathrm{~g} / \mathrm{L}$ MST

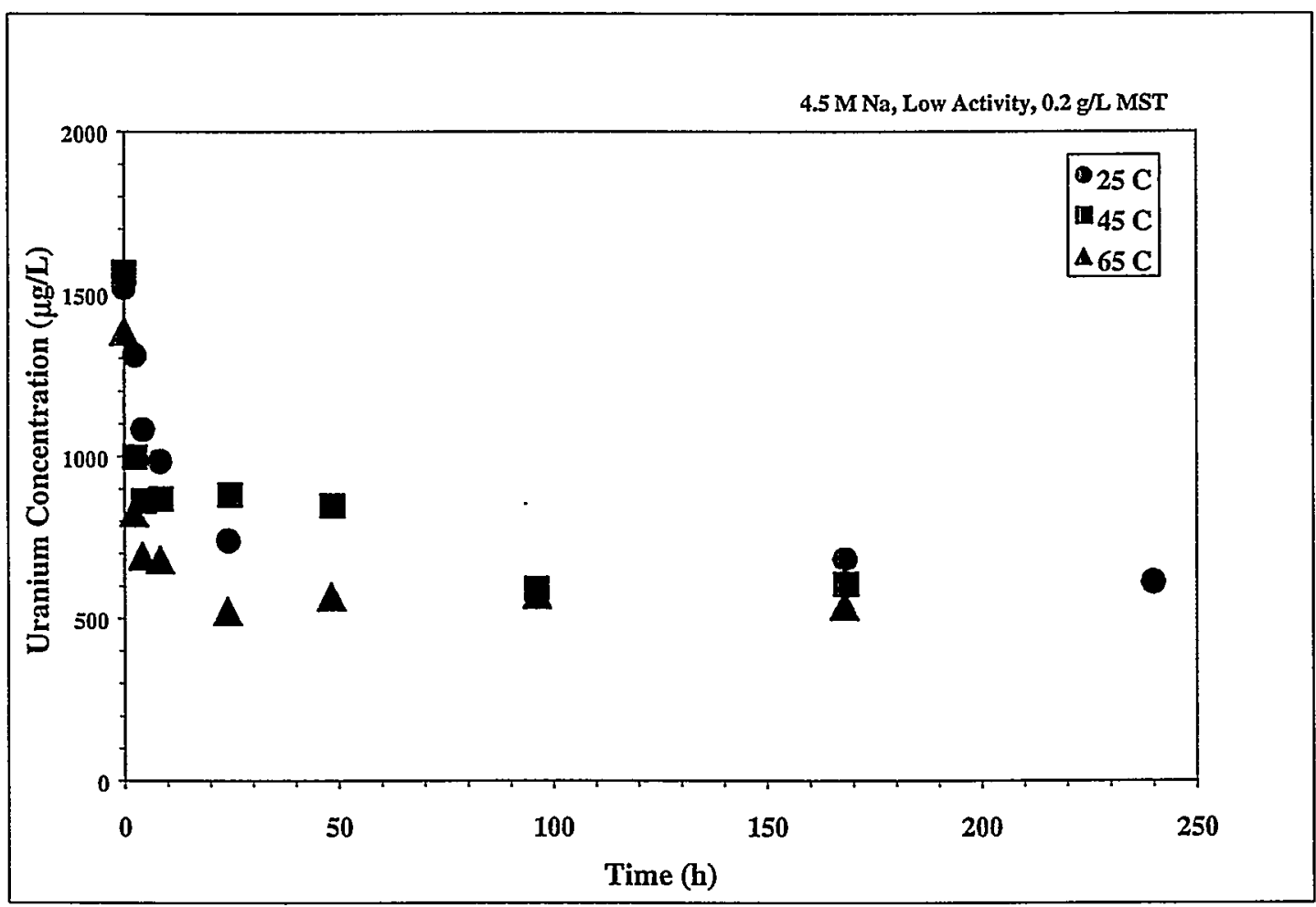

Figure 14. Uranium Removal - 4.5 $\mathrm{M} \mathrm{Na}^{+}$, High Activity, $0.2 \mathrm{~g} / \mathrm{L} \mathrm{MST}$

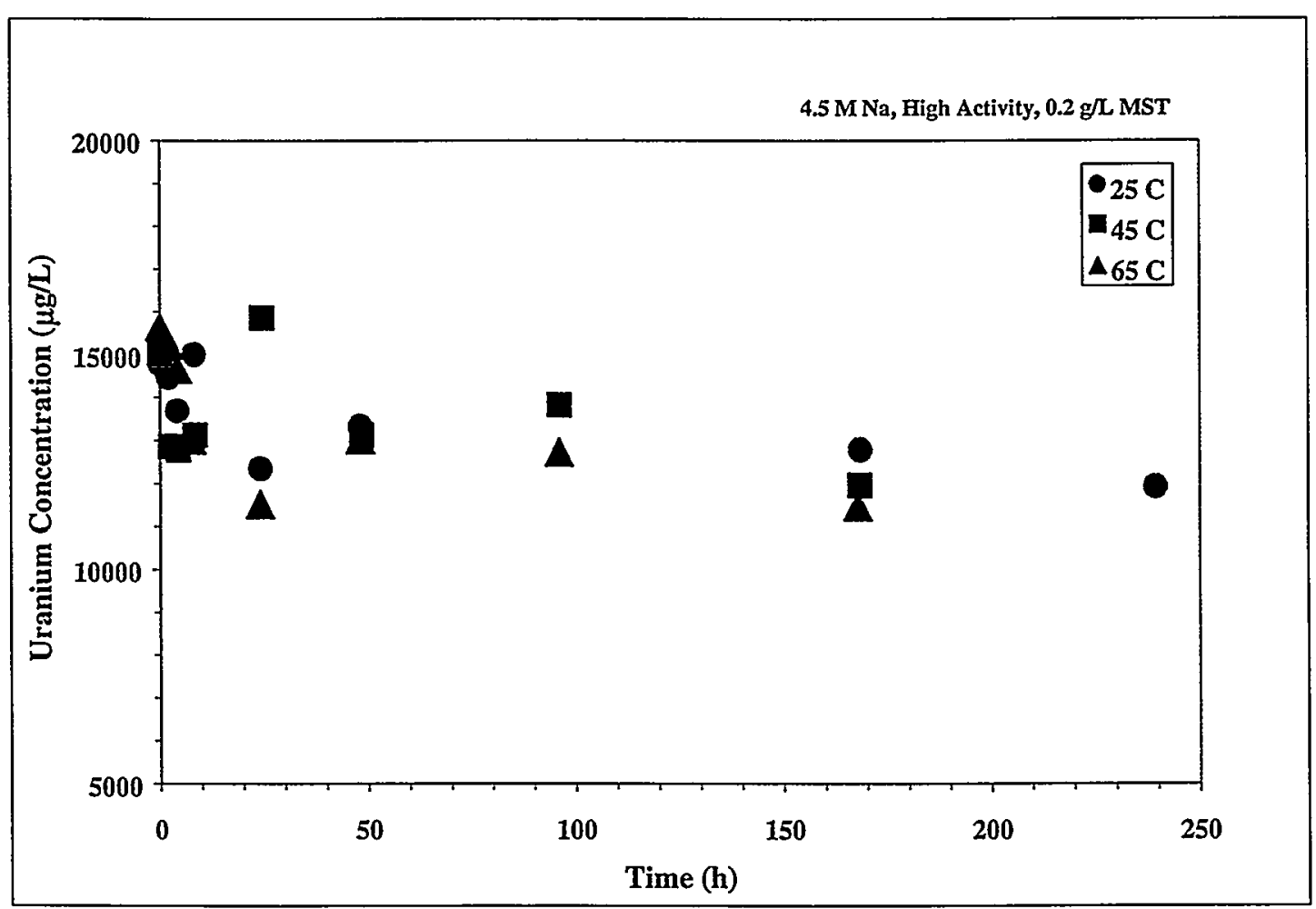


Figure 15. Uranium Removal - 7.5 $\mathrm{M} \mathrm{Na}^{+}$, Low Activity, $0.2 \mathrm{~g} / \mathrm{L}$ MST

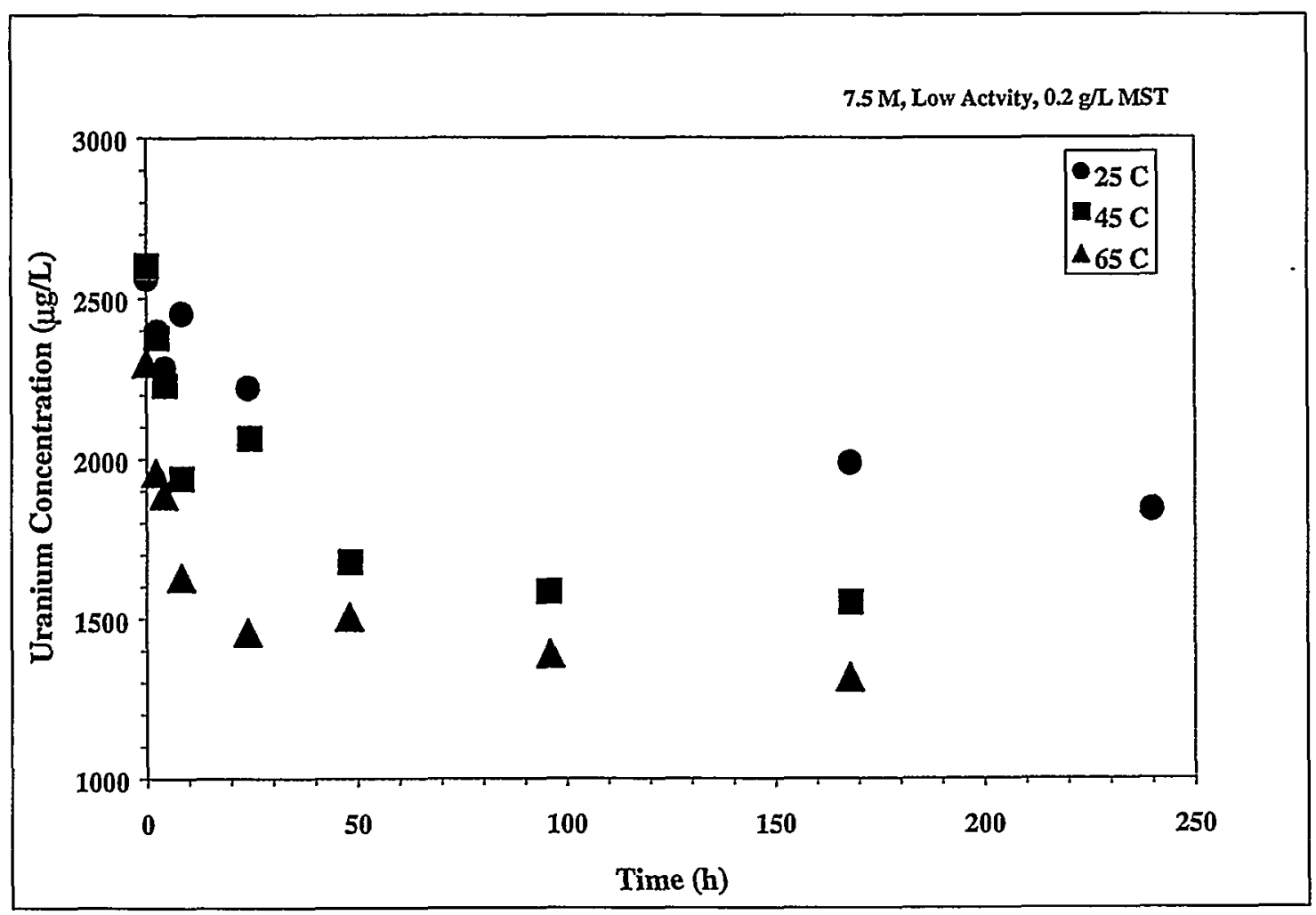

Figure 16. Uranium Removal - 7.5 $\mathrm{M} \mathrm{Na}^{+}$, High Activity, $0.2 \mathrm{~g} / \mathrm{L} \mathrm{MST}$

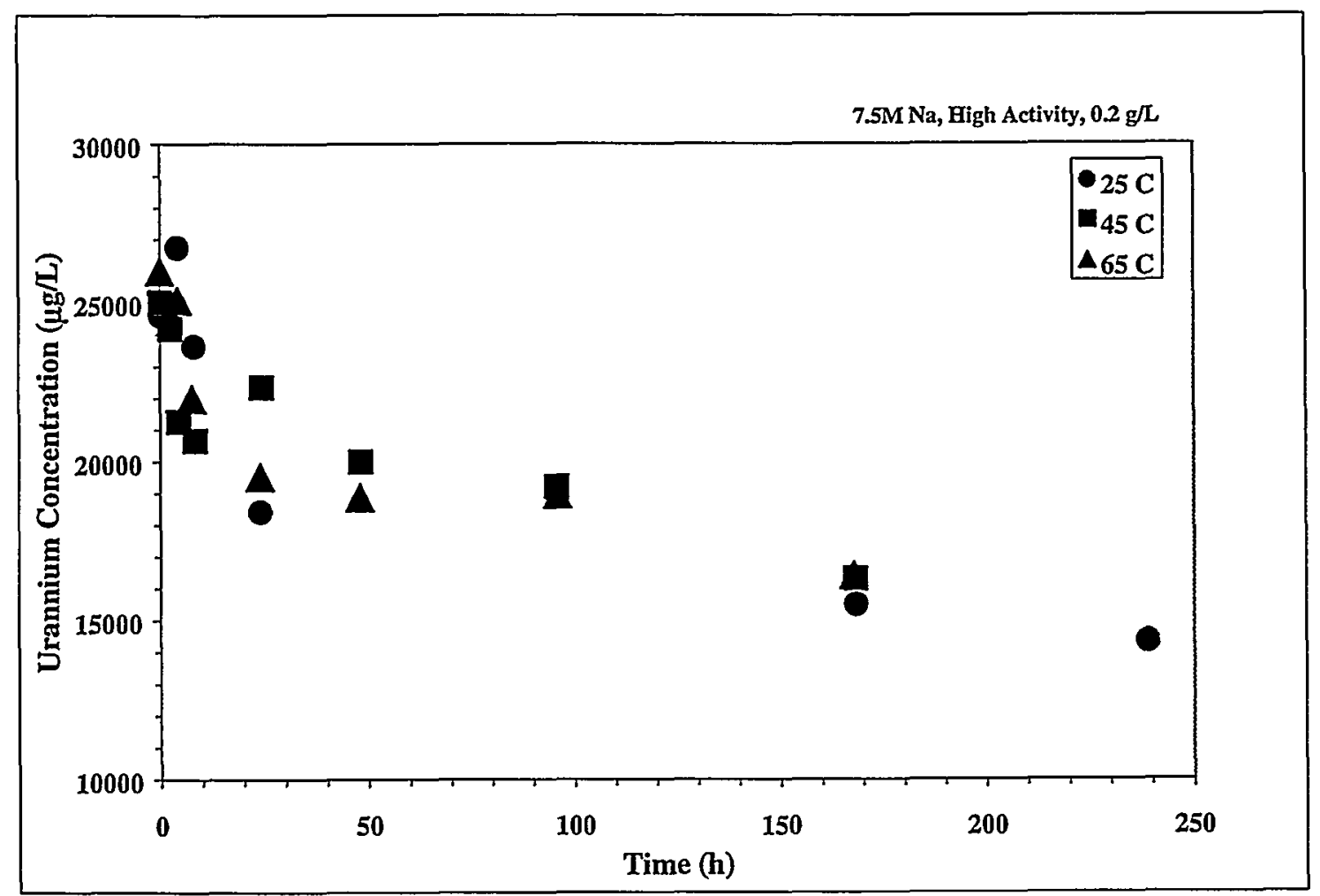




\section{Extent of Neptunium Removal}

Figures 17-20 present plots of the neptunium-237 concentration versus time for the low and high activity and $4.5 \mathrm{M}$ and $7.5 \mathrm{M}$ sodium ion solutions at each of the three temperatures and $0.2 \mathrm{~g} / \mathrm{L}$ MST. Appendices 9-22 provide the neptunium concentration data for all test conditions including the higher sodium ion concentrations and MST concentrations. The final neptunium-237 concentration exceeded the Z-Area limit in all of the high activity solution tests. The final neptunium-237 concentration was within the Z-Area limit for the low activity salt solutions at all temperatures for the low $(4.5 \mathrm{M})$ and intermediate $(6.0 \mathrm{M})$ sodium ion concentrations. At the high $(7.5 \mathrm{M})$ sodium ion concentration, the final neptunium-237 concentration was within the Z-Area limit only at 45 and $65^{\circ} \mathrm{C}$ and $2.0 \mathrm{~g} / \mathrm{L}$ MST (Figures 13 and 14).

Comparison of Figure $17\left(4.5 \mathrm{M} \mathrm{Na}^{+}\right.$, low activity, $0.2 \mathrm{~g} / \mathrm{L}$ MST) and Figure $19\left(7.5 \mathrm{M} \mathrm{Na}^{+}\right.$, low activity, $0.2 \mathrm{~g} / \mathrm{L} \mathrm{MST}$ ) indicates that the Np-237 concentration will be within the limit for feed solution to Z-Area by treating with $0.2 \mathrm{~g} / \mathrm{L}$ MST if the initial concentration of Np-237 is no more than $0.6 \mathrm{mg} / \mathrm{L}$ and the ionic strength does not exceed $4.5 \mathrm{M} \mathrm{Na}^{+}$. At initial $\mathrm{Np}-237$ concentrations above $0.6 \mathrm{mg} / \mathrm{L}, 0.2 \mathrm{~g} / \mathrm{L}$ MST is insufficient to remove enough neptunium to be within the limit. Figure 19 shows this trend. Note that decontamination factors $\left(\mathrm{C}_{0} / \mathrm{C}\right)$ increased with increased temperature in tests with $4.5 \mathrm{M} \mathrm{Na}^{+}$solutions, but not in tests with $7.5 \mathrm{M} \mathrm{Na}^{+}$solutions.

J. Fowler reported a predicted maximum concentration of neptunium-237 in waste tank of $500 \mu \mathrm{g} / \mathrm{L}$ [11], slightly higher than the low ionic strength/low activity solution case $(340 \mu \mathrm{g} / \mathrm{L})$ in these tests. Fowler shows an estimated initial uranium concentration for the projected case of 1.5 $\mathrm{mg} / \mathrm{L}$, well below the solubility limit (about $10 \mathrm{mg} / \mathrm{L}$ ) used in the current testing. Thus, we recommend additional tests at $0.5 \mathrm{mg} / \mathrm{L} \mathrm{Np}-237$ and $10 \mathrm{mg} / \mathrm{L}$ uranium to determine whether the process can satisfy the neptunium limit at MST concentrations of 0.2 and $0.4 \mathrm{~g} / \mathrm{L}$.

Given the high neptunium and uranium concentrations and the relatively low MST concentration, we expected tests at $0.2 \mathrm{~g} / \mathrm{L} \mathrm{MST}$ to severely stress the ability to meet the facility requirements. Unexpectedly, tests at 1.1 and $2.0 \mathrm{~g} / \mathrm{L}$ MST with the high activity solutions did not remove sufficient neptunium-237 to achieve final concentration below the Z-Area limit.

Calculations indicate that the mole ratio of all sorbates to MST is below 0.01 for the high activity solutions at MST concentrations $\geq 1.1 \mathrm{~g} / \mathrm{L}$ (see Appendix 24). At this low mole ratio, sufficient sites should be available to remove a large fraction of the neptunium and uranium. Final neptunium-237 and uranium concentrations in the high activity solutions with 1.1 and $2.0 \mathrm{~g} / \mathrm{L}$ MST (Appendices 18, $19,20,21 \& 23$ ) indicate greater neptunium removal with increasing temperature. In contrast, uranium removal does not exhibit the same behavior with temperature. We attribute these results to either a different mechanism for removal for neptunium at the higher temperatures (e.g., surface precipitation) or more rapid adsorption kinetics compared to uranium. 
Figure 17. Neptunium Removal - 4.5 $\mathrm{M} \mathrm{Na}^{+}$, Low Activity, $0.2 \mathrm{~g} / \mathrm{L}$ MST

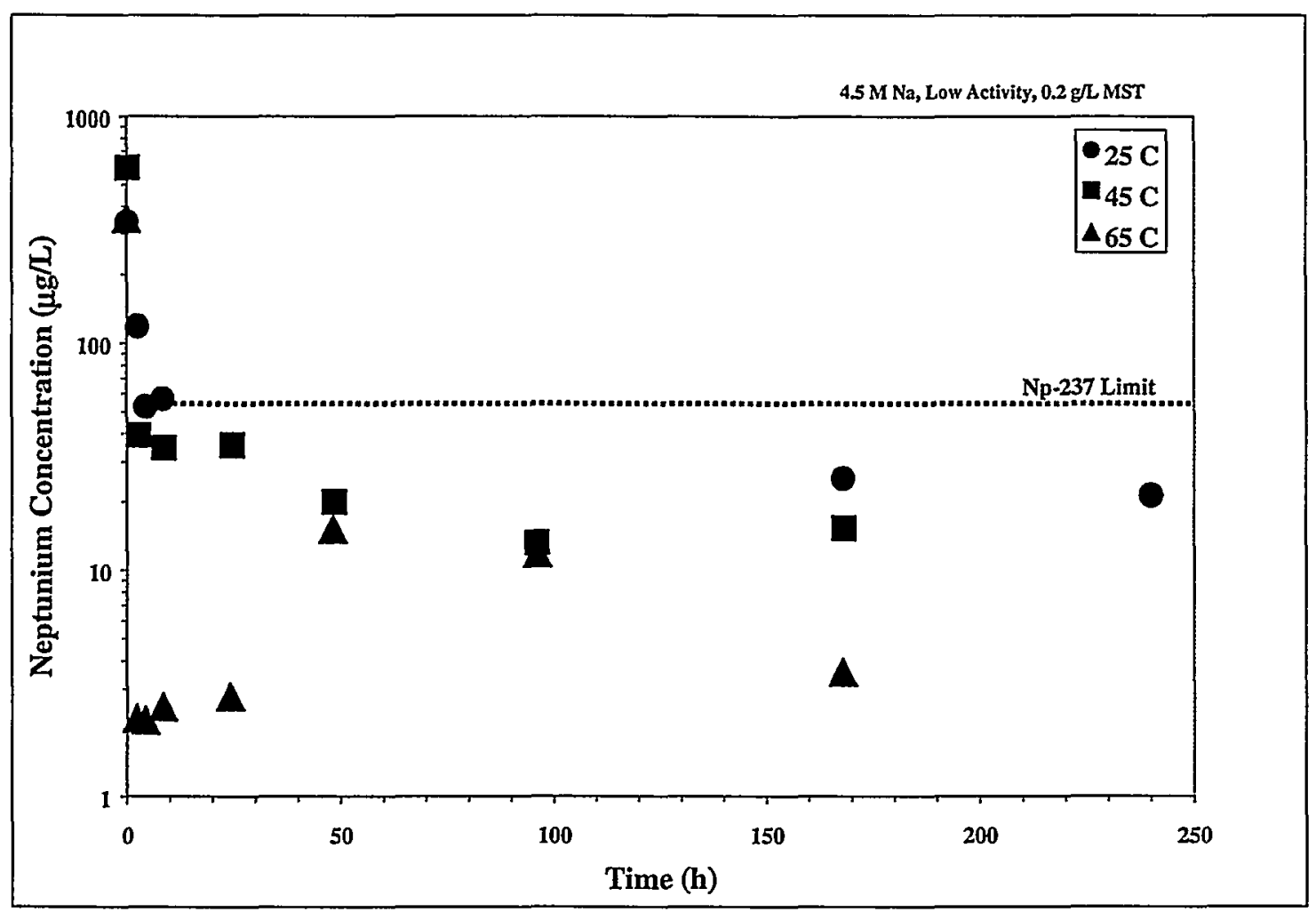

Figure 18. Neptunium Removal - 4.5 $\mathrm{M} \mathrm{Na}^{+}$, High Activity, $0.2 \mathrm{~g} / \mathrm{L} \mathrm{MST}$

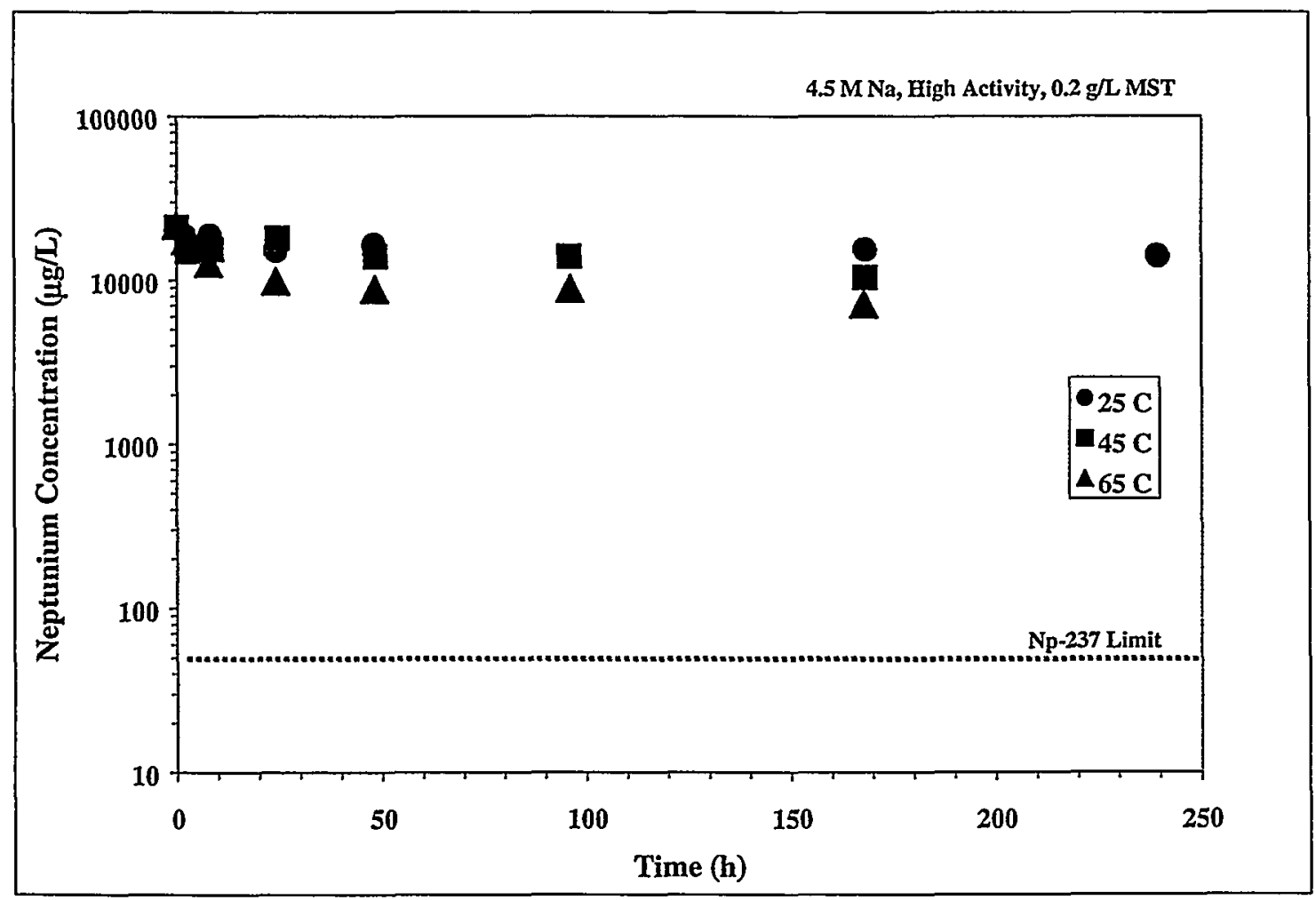



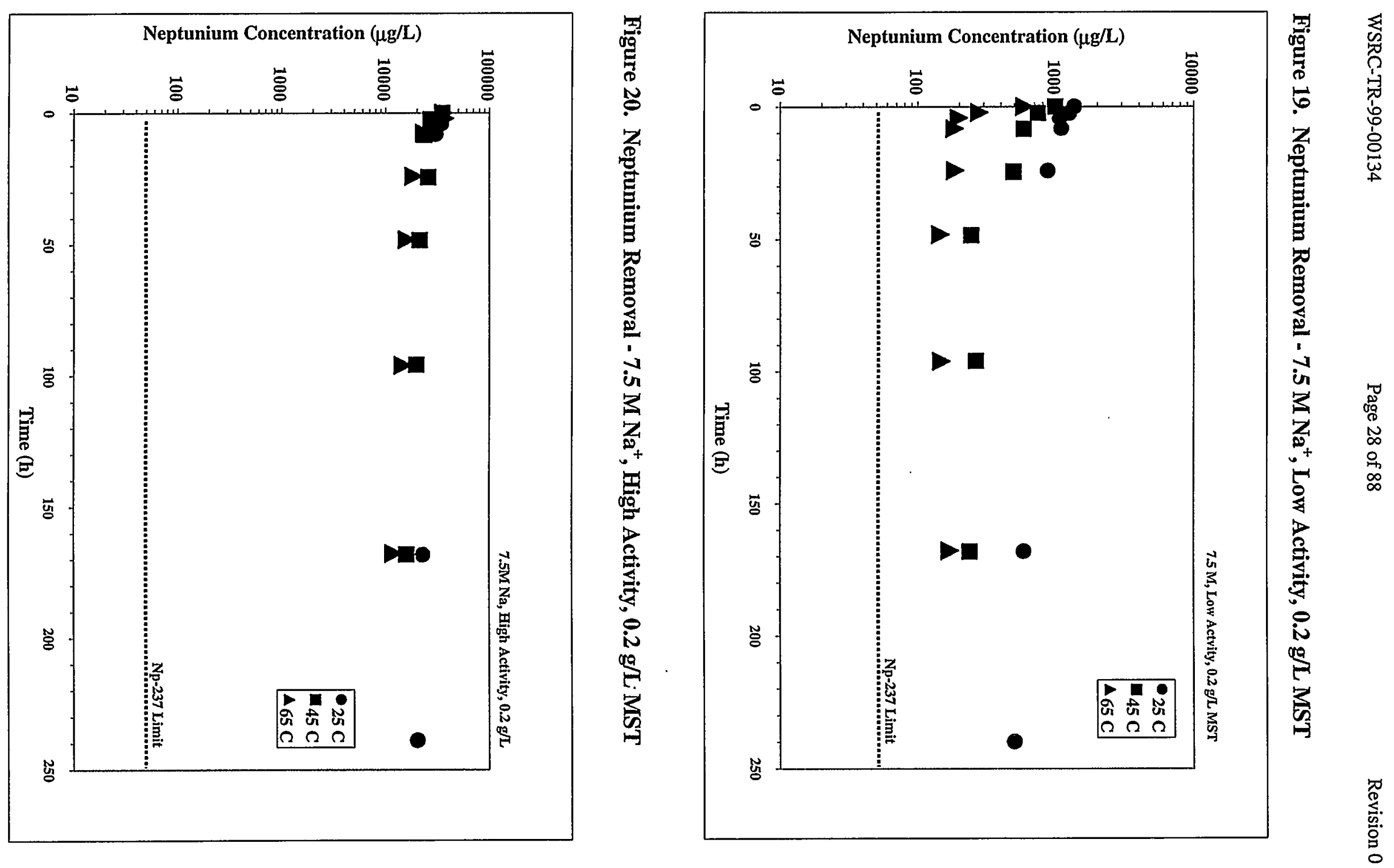


\section{Equilibrium Distribution Constants}

The equilibrium distribution constant, $\mathrm{K}_{\mathrm{d}}$, generally serves as the term used to evaluate the extent of removal in batch tests. One defines $\mathrm{K}_{d}$ as the ratio of the concentration of the sorbate on the MST to the equilibrium sorbate concentration in solution (equation 1) with units of $\mathrm{mL} / \mathrm{g}$.

$$
\left.\mathrm{K}_{\mathrm{d}}=\{\mathrm{M}\}_{\mathrm{s}} /[\mathrm{M}]_{\mathrm{aq}}^{\mathrm{e}}=\left(\left([\mathrm{M}]_{\mathrm{aq}}^{\mathrm{o}} /[\mathrm{M}]_{\mathrm{aq}}^{\mathrm{e}}\right)-1\right)\right) /[\mathrm{MST}]
$$

where, $\{M\}_{s}$ equals the equilibrium concentration of sorbate, $M$, on the MST sorbent in mmol/g, $[M]_{\text {aq }}^{e}$ equals the equilibrium concentration of sorbate, $\mathrm{M}$, in solution in units of $\mathrm{mmol} / \mathrm{mL}$, $[\mathrm{M}]_{\mathrm{sq}}^{\circ}$ equals the initial concentration of sorbate, $\mathrm{M}$, in solution in units of $\mathrm{mmol} / \mathrm{mL}$, and [MST] equals the concentration of MST in $\mathrm{g} / \mathrm{mL}$.

Appendices 5 - 7 provide the calculated $K_{d}$ values for each test. In some cases, the Appendix reports $a K_{d}$ as greater than a given value. This occurs when the equilibrium solution concentration of the sorbate falls below the detection limit of the analytical method.

As anticipated, strontium exhibited the highest $\mathrm{K}_{\mathrm{d}}$ values followed by plutonium. Neptunium and uranium exhibited similar $\mathrm{K}_{\mathrm{d}}$ values, with both much lower than those for strontium and plutonium. Although neptunium and uranium exhibited lower $K_{d}$ values, the MST adsorbs more neptunium and uranium on a mass basis than strontium and plutonium. The higher mass loading reflects the much higher mass concentrations of neptunium and uranium compared to strontium and plutonium (see Table V and Appendices 5 - 7).

Models for Predicting Equilibrium Sorbate Concentrations Statistical analysis of the equilibrium concentrations for each of the sorbates values using $\mathrm{JMP}^{\circledR}$ Version 3.2.2, a commercial software package from SAS Institute, Inc. identified which of the testing parameters significantly affected the equilibrium concentrations. The equilibrium concentration is modeled as a linear function of the independent parameters as shown in equation (2)

$$
[\mathrm{S}]_{\mathrm{e}}=\mathrm{a}+\mathrm{b} f(\mathrm{x})+\mathrm{c} f(\mathrm{y})+\mathrm{d} f(\mathrm{z})
$$

where, $[\mathrm{S}]_{\mathrm{e}}$ is the equilibrium sorbate concentration

$\mathrm{a}, \mathrm{b}, \mathrm{c}$ and $\mathrm{d}$ are constants

$f(\mathrm{x}), f(\mathrm{y})$ and $f(\mathrm{z})$ are some functional form of the independent parameter.

The functional form of the parameter can be the parameter, a mathematical function of the parameter (e.g., $\ln [\mathrm{Sr}]_{0}$ ) or a product of parameters (e.g., $[\mathrm{Sr}]_{0} \times[\mathrm{MST}]$ or $[\mathrm{Sr}]_{0} \times[\mathrm{Sr}]_{0}$ ). Initially, modeling included all of the test results. Upon further review, the analysis was divided into 3 subsets: (1) trials varying initial sorbate concentration, temperature, MST concentration and ionic strength (standard trials), (2) trials at constant ionic strength and MST concentration with and without mixing (mixing trials) and (3) trials at constant ionic strength and MST concentration with and without the addition of NaTPB and sludge solids (spiked trials). 
Effects of Mixing and Addition of NaTPB and Sludge Solids

Results from the analysis of the latter two subsets indicated the following: (1) mixing is statistically significant for the determination of the final strontium and plutonium concentrations but not uranium and neptunium concentrations, (2) addition of sludge is statistically significant for the determination of final strontium, plutonium and uranium concentrations and (3) addition of NaTPB is not statistically significant for the determination of any final sorbate concentrations. Table $\mathrm{X}$ provides a summary of the parameters, parameter coefficients and significance levels for the mixing and spiked trials. Appendices 25 and 26 provide details of these statistical evaluations. Mixing could affect rate of sorption, but should not affect equilibrium sorbate concentrations. We believe the results obtained above for mixing indicates that the system may not be at true equilibrium at the time of the final sampling. Alternatively, mixing could be deagglomerating the MST making more sites available for sorption resulting in lower final sorbate concentrations.

\section{Table X. Summary of Statistical Model Parameters for Mixing and Spiked Trials}

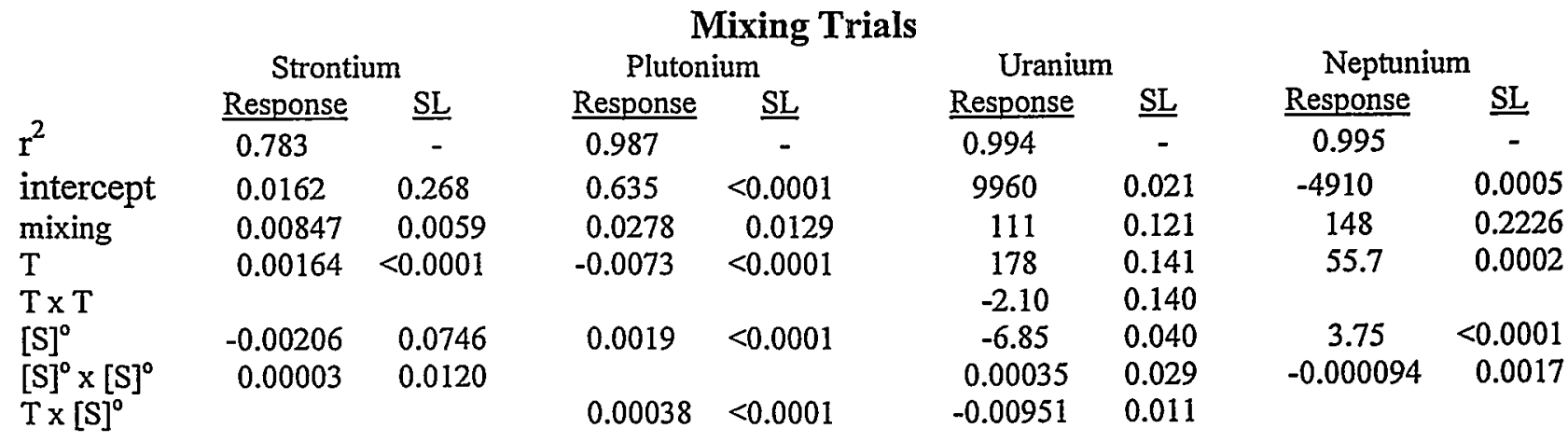

\begin{tabular}{|c|c|c|c|c|c|c|c|c|}
\hline & \multicolumn{6}{|c|}{ Spiked Trials } & \multirow{2}{*}{\multicolumn{2}{|c|}{ Neptunium }} \\
\hline & Stronti & & Pluton & & Uraniun & & & \\
\hline & Response & $\underline{\mathrm{SL}}$ & Response & SL & $\underline{\text { Response }}$ & $\underline{\text { SL }}$ & Response & $\underline{\mathrm{SL}}$ \\
\hline $\mathrm{r}^{2}$ & 0.824 & - & 0.984 & - & 0.989 & - & 0.980 & $\overline{-}$ \\
\hline intercept & 0.0756 & 0.110 & 0.223 & $<0.0001$ & 2710 & 0.272 & -4980 & 0.0310 \\
\hline NaTPB & 0.00481 & 0.482 & 0.0118 & 0.572 & -264 & 0.102 & -192 & 0.574 \\
\hline Sludge & 0.0197 & 0.0090 & -0.0527 & 0.0193 & 490 & 0.0052 & 47.3 & 0.890 \\
\hline$T$ & -0.00303 & 0.165 & -0.00166 & 0.0597 & 0.836 & 0.933 & 55.3 & 0.0587 \\
\hline $\mathrm{T} \times \mathrm{T}$ & 0.000065 & 0.0111 & & & & & & \\
\hline$[\mathrm{S}]^{\circ}$ & 0.00124 & 0.0015 & 0.0143 & 0.0011 & -1.33 & 0.272 & 3.74 & 0.0138 \\
\hline$[\mathrm{S}]^{0} \times[\mathrm{S}]^{\circ}$ & & & -0.000047 & 0.0122 & 0.0000856 & 0.1432 & -0.000098 & 0.0530 \\
\hline $\mathrm{T} \times[\mathrm{S}]^{\circ}$ & 0.00003 & 0.0120 & & & -0.00313 & 0.0427 & -0.0123 & $<0.0001$ \\
\hline
\end{tabular}

Response is the value of the parameter coefficient $\mathrm{SL}=$ Significance Level (a value of $\leq 0.05$ is considered statistically significant.

$\mathrm{r}^{2}=$ Correlation coefficient, $\mathrm{T}=$ temperature $\left({ }^{\circ} \mathrm{C}\right),[\mathrm{S}]^{\circ}=$ initial sorbate concentration in $\mu \mathrm{g} / \mathrm{L}$.

Additional tests provided additional insight into the effects of mixing on sorbate removal (see Table IV in Experimental Section). These tests utilized the low and high activity $4.5 \mathrm{M} \mathrm{Na}^{+}$solutions under well stirred (magnetic) and gently agitated (orbital) conditions. Figures $21-23$ present graphs of strontium, plutonium and neptunium concentrations, respectively, versus time for both the low 
activity and high activity solutions. Initial concentrations are omitted from the graphs to allow plotting both axes on a logarithmic scale.

For the high activity solutions, there is no difference in the rate of removal for any of the three sorbates. The extent of removal is higher for the magnetically stirred test. We attribute this result to the slightly higher MST concentration in the magnetically stirred test $(1.75 \mathrm{~g} / \mathrm{L})$ compared to the orbital shaken test $(1.56 \mathrm{~g} / \mathrm{L})$.

For the low activity solution, the rate of strontium removal is similar for both mixing types as evidenced by similar slopes. The orbital shaker achieves equilibrium more quickly due to the higher MST concentration $(3.51 \mathrm{~g} / \mathrm{L}$ vs. $1.75 \mathrm{~g} / \mathrm{L}$ ). Results after about 1 hour into the test have high experimental uncertainties from the counting statistics. Longer counting times would decrease this uncertainty. However, due to large differences in MST concentrations and additional costs, we chose not to perform longer counting times for this test set.

\section{Figure 21. Affect of Mixing on Strontium Removal}

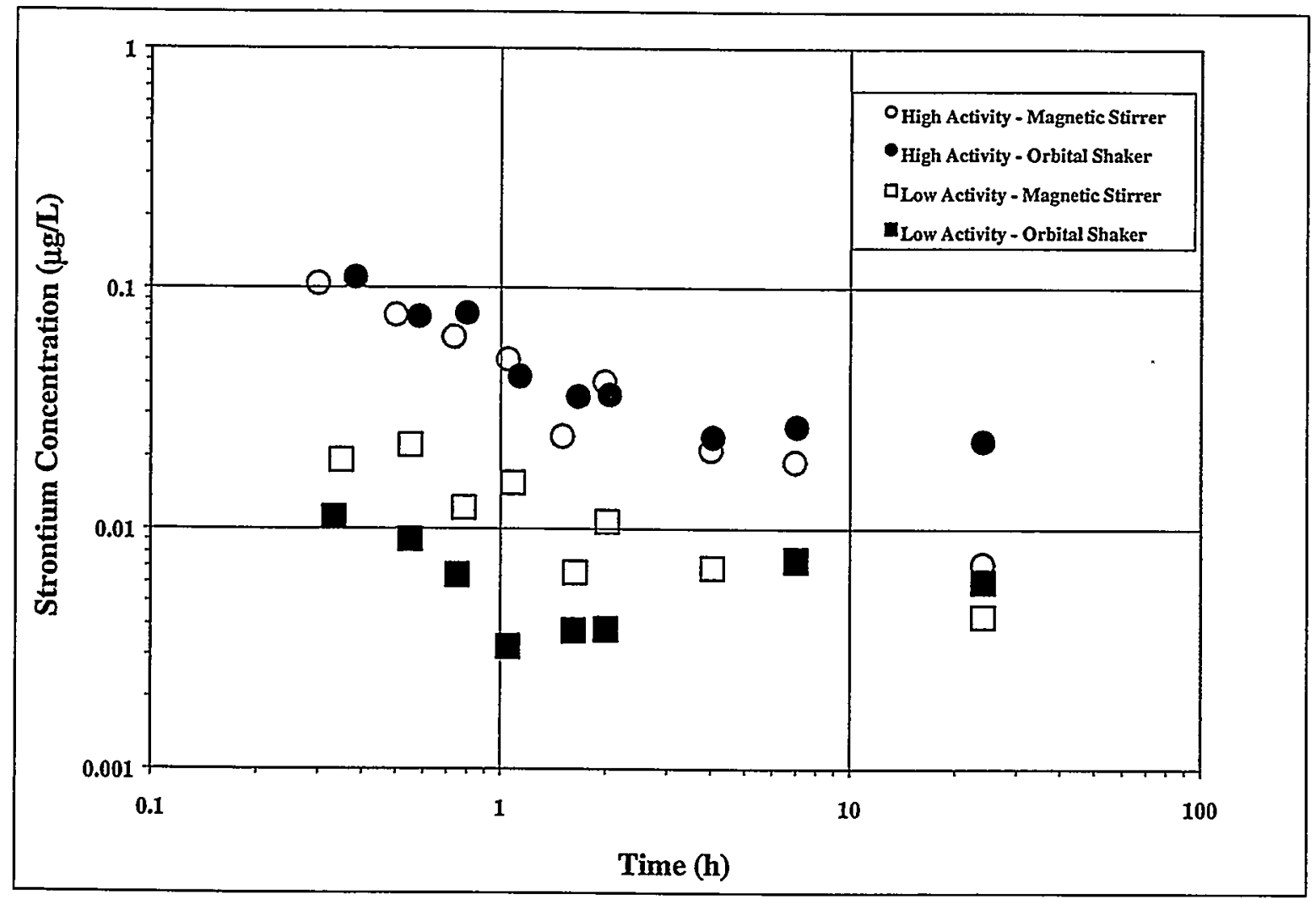


Figure 22. Affect of Mixing on Plutonium Removal

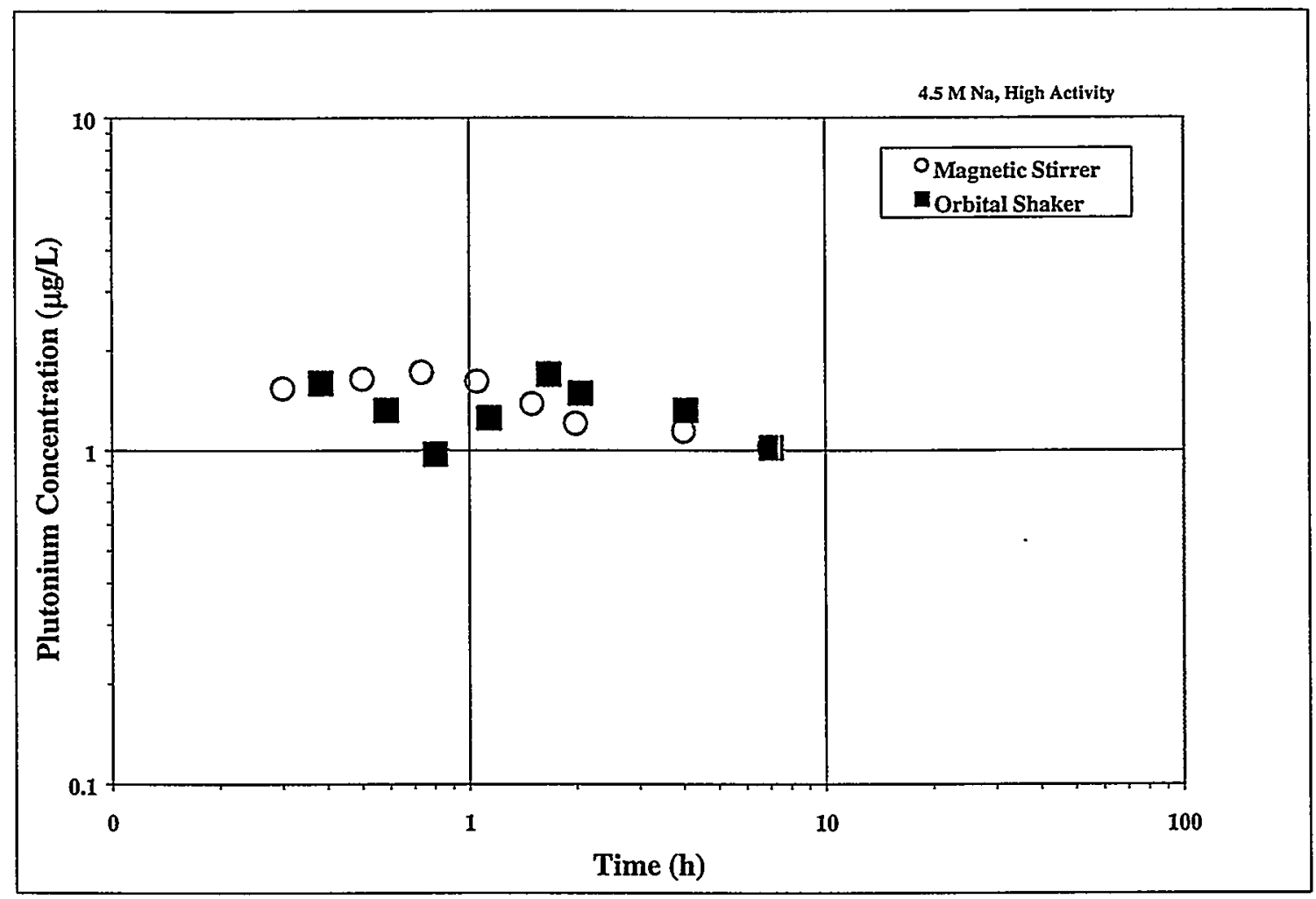

Figure 23. Affect of Mixing on Neptunium Removal

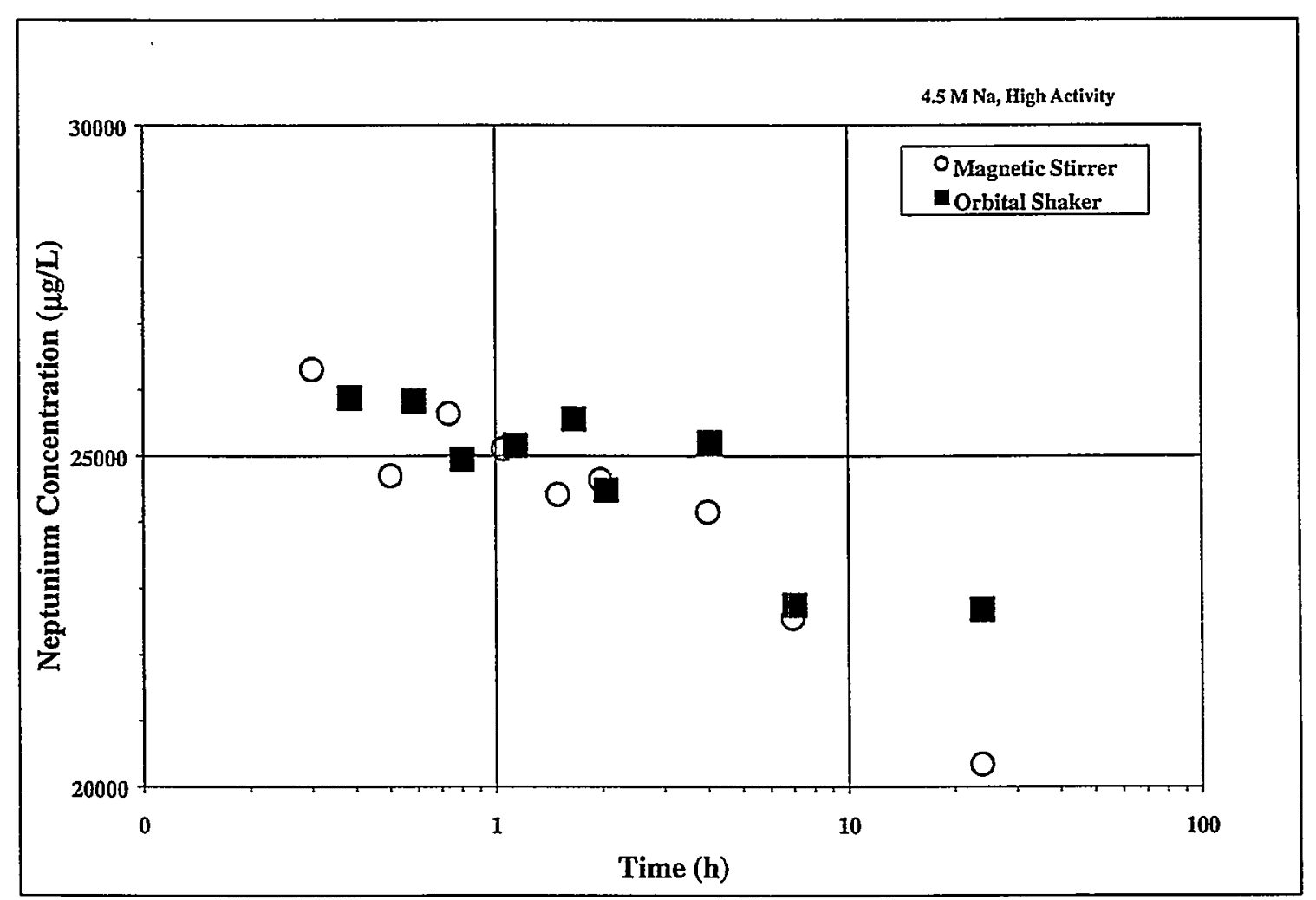


Analysis of the tests indicated that the equilibrium concentration of strontium, plutonium and uranium is affected by the addition of $400 \mathrm{mg} / \mathrm{L}$ of synthetic Purex sludge. Adsorption of plutonium and uranium species by hydrous iron oxides under alkaline conditions has been previously reported $[14,15]$. The correlation coefficients of the fitted model are 0.824 for strontium, 0.984 for plutonium and 0.990 for uranium. The lower correlation coefficient for strontium indicates a poorer fit of the data.

When compared to other parameters (e.g., initial sorbate concentration, MST concentration, ionic strength, etc.), the effect of sludge solids on equilibrium sorbate concentration is small (e.g., compare predictive equations between special spiked trials to those in the standard trials). During HLW processing, supernate and some amount of sludge solids will pass into the salt processing facility. The sludge solids will have been in contact with the waste solution and thus be at or near equilibrium with respect to adsorption of solution phase species. Mixing two different waste materials would change the equilibrium, but would not result in complete desorption of species from the sludge solids. Thus, the likelihood is extremely low that any sludge solids could enter into the supernate processing facility without previously adsorbed strontium, plutonium and uranium. Therefore, we conclude that the impact of sludge solids is negligible in considering the rate and extent of strontium, plutonium, uranium and neptunium removal with MST.

\section{Equilibrium Sorbate Concentrations}

Predictive models were developed from the results of the standard trials in which the concentrations of the sorbates, MST and sodium ion concentration (ionic strength or Z) and the temperature were varied. Appendices $25-28$ provide details of the fitted models. The upper and lower $95 \%$ confidence intervals are much narrower for strontium, uranium and neptunium compared to plutonium. For example the predicted values for the upper and lower $95 \%$ confidence interval for a single predicted condition vary by about $\pm 20 \%$ from the average value for strontium, uranium and neptunium. For plutonium the range varies by about $\pm 100 \%$. The wide confidence intervals do not result from replicate variability, which proved small in most tests. We attribute the model uncertainty to one or more unidentified parameters, parameter interactions confounded with main factors, and to the difficulty imposed by the analytical detection limit in many experiments particularly with plutonium measurements.

\section{Equilibrium Strontium Concentration}

Statistically significant parameters affecting strontium removal include temperature, ionic strength and the initial strontium concentration. The analysis provided the following predictive equation for equilibrium strontium concentration:

$$
\begin{aligned}
& {[\mathrm{Sr}]_{\text {aq }}^{\mathrm{e}}=4.343+1.022 *[\mathrm{MST}]+0.00574 * \mathrm{~T}-1.68 * \mathrm{Z}-0.00314 *[\mathrm{Sr}]^{0}{ }_{\text {aq }}} \\
& -0.181 * Z^{*}[\mathrm{MST}]+0.159^{*} Z^{2}+0.000116^{*}\left\{[\mathrm{Sr}]_{\mathrm{aq}}^{0}\right\}^{2} \\
& -0.00119 * Z^{*}[\mathrm{Sr}]_{\mathrm{aq}}^{\mathrm{o}}-0.00164 *[\mathrm{MST}]^{*}[\mathrm{Sr}]_{\mathrm{aq}}^{0}+0.0000832 * \mathrm{~T}^{*}[\mathrm{Sr}]_{\mathrm{aq}}^{0} \\
& -0.00494 * \mathrm{~T} *[\mathrm{MST}]
\end{aligned}
$$

where $\mathrm{T}=$ Temperature $\left({ }^{\circ} \mathrm{C}\right), \mathrm{Z}=$ ionic strength $(\mathrm{M})$ and $[\mathrm{Sr}]^{\circ}$ aq $=$ the initial strontium concentration $(\mu \mathrm{g} / \mathrm{L})$. The correlation coefficient for the fitted model is 0.972 . 
Equilibrium Plutonium Concentration

Statistically significant parameters affecting the equilibrium plutonium concentration include MST concentration, ionic strength, temperature, the initial plutonium concentration and cross terms including all of the previous parameters. The analysis gave the following predictive equation for the equilibrium plutonium concentration:

$$
\begin{aligned}
& {[\mathrm{Pu}]_{\text {aq }}^{\mathrm{e}}=7.40+0.276^{*}[\mathrm{MST}]-2.13^{*} \mathrm{Z}-0.0536^{*} \mathrm{~T}+0.0187^{*}[\mathrm{Pu}]_{\text {aq }}^{0}} \\
& +0.0196 *[\mathrm{MST}] * \mathrm{~T}-0.0302 *[\mathrm{MST}] * \mathrm{Z}+0.294 * \mathrm{Z}^{2}+0.00131 * \mathrm{~T}^{2} \\
& \left.-0.00046 *\{\mathrm{Pu}]_{\mathrm{aq}}^{0}\right\}^{2}+0.004413 *[\mathrm{MST}]^{*}[\mathrm{Pu}]_{\mathrm{aq}}^{0}-0.0192 * \mathrm{~T}^{\circ} \mathrm{Z} \\
& \left.+0.0122 * \mathrm{Z}^{*}\right]^{*}[\mathrm{Pu}]^{\mathrm{oq}}
\end{aligned}
$$

The correlation coefficient for the fitted model is 0.789 . The lack of fit is poorer for plutonium than the other sorbates. We attribute the poorer fit to the high number of equilibrium concentrations (30 out of 60 tests) which were below the analytical detection limit.

Equilibrium Uranium Concentration

Statistically significant parameters affecting the equilibrium uranium concentration include MST concentration, ionic strength, initial uranium concentration and cross terms including these parameters. The analysis yielded the following predictive equation for the equilibrium uranium concentration:

$$
\begin{aligned}
{[\mathrm{U}]_{\mathrm{aq}}^{\mathrm{e}}=} & 15480-2480^{*}[\mathrm{MST}]-4650^{*} \mathrm{Z}+0.824^{*}[\mathrm{U}]_{\mathrm{aq}}^{\mathrm{o}}+349 *[\mathrm{MST}]^{* \mathrm{Z}} \\
& +329^{*} \mathrm{Z}^{2}-0.27^{*}[\mathrm{MST}]^{*}[\mathrm{U}]_{\mathrm{aq}}^{\mathrm{o}}-0.0137^{*} \mathrm{Z}^{*}[\mathrm{U}]_{\mathrm{aq}}^{\mathrm{o}} .
\end{aligned}
$$

where $[M S T]=$ MST concentration $(g / L), Z=$ ionic strength $(M),[U]^{\circ}{ }_{a q}=$ the initial uranium concentration $(\mu \mathrm{g} / \mathrm{L})$ and $\mathrm{T}=$ Temperature $\left({ }^{\circ} \mathrm{C}\right)$. The correlation coefficient for the fitted model is 0.979 .

\section{Equilibrium Neptunium Concentration}

Statistically significant parameters affecting the equilibrium neptunium concentration include MST concentration, ionic strength, temperature and cross terms including these parameters and the initial neptunium concentration. The analysis resulted in the following predictive equation for the equilibrium neptunium concentration:

$$
\begin{aligned}
& \left.[\mathrm{Np}]_{\text {aq }}^{\mathrm{e}}=2140-240 *[\mathrm{MST}]-652 * \mathrm{Z}-12.6^{*} \mathrm{~T}+0.967^{*}\right]^{*}[\mathrm{~Np}]^{0}{ }_{\text {aq }} \\
& -31.1 *[\mathrm{MST}] * \mathrm{~T}+238 *[\mathrm{MST}] * \mathrm{Z}+8.55 * \mathrm{Z} * \mathrm{~T} \\
& -0.116^{*}[\mathrm{MST}]^{*}[\mathrm{~Np}]_{\text {aq }}^{0}-0.0103 * \mathrm{~T}^{*}[\mathrm{~Np}]_{\text {aq }}^{0} \text {. }
\end{aligned}
$$

where $\mathrm{T}=$ Temperature $\left({ }^{\circ} \mathrm{C}\right), \mathrm{Z}=$ ionic strength $(\mathrm{M}),[\mathrm{MST}]=$ concentration of monosodium titanate and $[\mathrm{Np}]^{\circ}{ }_{\text {aq }}=$ the initial neptunium-237 concentration $(\mu \mathrm{g} / \mathrm{L})$. The correlation coefficient for the fitted model is 0.978 .

Removal Rates

None of the test data fit first-order or second-order kinetic expressions. Previously, we reported the time to reach equilibrium or the time at which a sharp decrease in the slope of the activity- 
concentration curve occurred as the primary measure for reaction rate at $25^{\circ} \mathrm{C}$ [13]. Analysis of the $25^{\circ} \mathrm{C}$ along with the results obtained from the tests at 45 and $65^{\circ} \mathrm{C}$ did not produce a model with high correlation coefficients.

Beck et al. showed that the more important measure for sizing and establishing the residence time for the continuous stirred tank reactor (CSTR) in the Small Tank Tetraphenylborate process involves the rate at the time when the sorbate concentration passes through the required Z-Area limit [12]. The effective sodium ion concentration in the CSTR will average $4.7 \mathrm{M}$, just slightly higher than the low sodium ion concentration ( $4.5 \mathrm{M}$ ) solution tested in this study. The proposed process will use a target MST concentration in the CSTR of $0.2 \mathrm{~g} / \mathrm{L}$. Thus, we calculated the rates at a MST concentration of $0.2 \mathrm{~g} / \mathrm{L}$ for those tests that satisfied the Z-Area limit for a specific sorbate. Tables XI, XII and XIII present those rates for strontium, plutonium and neptunium, respectively, determined from the tests at the minimum $(4.9 \mathrm{M})$ and maximum ionic strengths $(8.2 \mathrm{M})$ (i.e., $4.5 \mathrm{M} \mathrm{Na}^{+}$and $7.5 \mathrm{M} \mathrm{Na}{ }^{+}$).

For the $4.5 \mathrm{M} \mathrm{Na}^{+}$solutions, the strontium concentration passed below both Sr-90 limits ( 6.5 and 0.76 $\mu \mathrm{g} / \mathrm{L}$ total $\mathrm{Sr}$ ) (see Figures 5 and 6 ) even though the initial strontium concentrations differed by about a factor of $10-12$. Incremental rates for strontium in the $4.5 \mathrm{M} \mathrm{Na}^{+}$solutions ranged from 0.27 to $1.94 \mu \mathrm{g} / \mathrm{L}$-h (see Table XI). As seen in Table XI, the strontium concentration achieved the 5.2 at \% Sr-90 limit $(7.3 \mu \mathrm{g} / \mathrm{L}$ total $\mathrm{Sr})$, but did not achieve the 45 at \% Sr-90 limit $(0.84 \mu \mathrm{g} / \mathrm{L}$ total Sr). Thus, the incremental rate reported in Table XI for the $7.5 \mathrm{M} \mathrm{Na}^{+}$solutions is that based on 5.2 at \% Sr-90.

Strontium removal rates increased upon an increase in the initial strontium concentration (compare low and high activity rates for $4.5 \mathrm{M}$ and $7.5 \mathrm{M} \mathrm{Na}^{+}$solutions in Table XI). Note that the increase in removal rates between the low and high activity solutions is much greater for the lower sodium ion concentration. We attribute the smaller change in removal rates at the higher sodium ion concentration (7.5 M) to increased competition from sodium ions for adsorption sites on the MST (i.e., decreased chemical potential at higher $\mathrm{Na}^{+}$concentrations).

The strontium removal rate for the $4.5 \mathrm{M}$ low activity solution at $25^{\circ} \mathrm{C}$ proved much lower than those measured at 45 and $65^{\circ} \mathrm{C}$ (see Table XI). Rates at the higher activity solution (4.5 M Na ${ }^{+}$) and higher sodium ion concentrations (both low and high activity) exhibited no significant temperature effect. We attribute the large difference in incremental rates for the low-activity $4.5 \mathrm{M} \mathrm{Na}^{+}$solutions in part to the wide sampling intervals during the initial stage of the test. The first three samples were taken at about 2, 4 and 8 hours. The strontium concentration reached the limit within 2 hours at 45 and $65^{\circ} \mathrm{C}$, but just missed at $25^{\circ} \mathrm{C}$. After 4 hours, the strontium concentration was below the limit at $25^{\circ} \mathrm{C}$. Thus, the incremental rate for the $25^{\circ} \mathrm{C}$ test used the $2-4$ hour interval, which includes a much smaller change in the strontium concentration than during the first 2 hour interval. We recommend conducting tests with more frequent sampling at the beginning of the test to provide a more accurate determination of strontium removal rates. 
Table XI. Incremental Removal Rates for Strontium Upon Reaching Sr-90 Limit for Feed of Decontaminated Salt Solution to Z-Area

\begin{tabular}{|c|c|c|c|c|}
\hline \multicolumn{5}{|c|}{ Incremental Rate $(\mu \mathrm{g} / \mathrm{L}-\mathrm{h})^{\mathrm{a}}$} \\
\hline & $4.5 \mathrm{MNa}^{+}(45$ & at $\% \mathrm{Sr}-90)$ & $7.5 \mathrm{M} \mathrm{Na}^{+}$ & 2 at $\% \mathrm{Sr}-90)$ \\
\hline Temp. $\left({ }^{\circ} \mathrm{C}\right)$ & Low Activity & High Activity & Low Activ & High Activity \\
\hline 25 & 0.27 & 30.6 & 1.91 & 5.18 \\
\hline 45 & 1.89 & 21.3 & 2.08 & 3.75 \\
\hline 65 & 1.94 & 26.7 & 2.62 & 4.55 \\
\hline & $\begin{array}{l}\text { mental rate detern } \\
\mathrm{d} \text { through the } \mathrm{Z}-\mathrm{A} \\
\text { activity solutions } \\
\mathrm{N} \mathrm{Na}{ }^{+} \text {, density }=1 \\
\text { nt of } 5.2 \text { at } \%(6.5 \\
\text { density }=1.336 \mathrm{~g}\end{array}$ & $\begin{array}{l}\text { ined for the time } \\
\text { rea Sr-90 limit for } \\
\text { it low ionic strengt } \\
.206 \mathrm{~g} / \mathrm{mL} \text { ) passed } \\
\mu \mathrm{g} / \mathrm{L} \text { ) and } 45 \text { at } \% \\
\mathrm{~mL}) \text {, the low and } \mathrm{h}\end{array}$ & $\begin{array}{l}\text { d during whic } \\
\text { ontaminated s } \\
\text { ough Sr-90 lin } \\
76 \mu \mathrm{g} / \mathrm{L}) \text {. At } \\
\text { activity soluti }\end{array}$ & $\begin{array}{l}\text { le strontium concentration } \\
\text { olution. Both low activity and } \\
\text { calculated based on a Sr-90 } \\
\text { iigh ionic strength }(7.5 \mathrm{M} \\
\text { passed through the Sr-90 limit }\end{array}$ \\
\hline
\end{tabular}

The initial plutonium concentrations in the low activity solutions for both the $4.5 \mathrm{M}$ (Figure 9) and 7.5 M (Figure 11) $\mathrm{Na}^{+}$solutions are below both the WG and HS mass limits and, therefore, one cannot calculate incremental rates for these tests. For the high activity solutions, the plutonium concentration decreased below the WG limit (Figures 10 and 12). The HS limit nearly equals the lower detection limit of the ICP-MS analytical method and, thus, we could not reliably determine an incremental rate at the HS limit.

Based on the WG incremental rates, increasing temperature appears to increase plutonium removal rates (see Table XII). Generally, the plutonium concentration fell below the limit within about 4 hours during these tests indicating fairly rapid adsorption rates. These rates may be conservatively low as the sampling interval was large during which the limit was reached. More frequent sampling as carried out in the later mixing tests indicated that the removal of plutonium reached equilibrium within 60 minutes (see Figure 22). The more recent tests occurred at a much higher MST concentration compared to the earlier tests and, thus, the rates cannot be compared directly with those reported in Table XII. The authors recommend additional tests at lower MST concentrations with more frequent sampling to provide more data points about the point where the plutonium concentration reaches the Z-Area limit.

Table XII. Incremental Removal Rates for Plutonium Upon Reaching Total Alpha Limit for Feed of Decontaminated Salt Solution to Z-Area

\begin{tabular}{|c|c|c|}
\hline \multirow[b]{2}{*}{ Temperature $\left({ }^{\circ} \mathrm{C}\right)$} & \multicolumn{2}{|c|}{$\begin{array}{l}\text { Incremental Rate }(\mu \mathrm{g} / \mathrm{L}-\mathrm{h})^{\mathrm{a}} \\
\text { Weapons Grade Isotopics }\end{array}$} \\
\hline & $4.5 \mathrm{MNa}^{+}$ & $\underline{7.5 \mathrm{MNa}^{+}}$ \\
\hline 25 & 26.7 & 7.05 \\
\hline 45 & 62.9 & 11.1 \\
\hline 65 & 70.6 & 64.1 \\
\hline \multicolumn{3}{|c|}{$\begin{array}{l}\text { a experimental limitations prevented obtaining removal rates for the } \\
\text { low activity solutions near the } Z \text {-Area limits and for the high activity } \\
\text { solutions at the heat source limits ( } 1.6 \mu \mathrm{g} / \mathrm{L} \text { for } 4.5 \mathrm{M} \mathrm{Na}^{+} \text {solutions } \\
\text { and } 1.8 \mu \mathrm{g} / \mathrm{L} \text { for } 7.5 \mathrm{M} \mathrm{Na}^{+} \text {solutions). }\end{array}$} \\
\hline
\end{tabular}


Np-237 removal reached the Z-Area feed limit only in the tests with the lower ionic strength and lower neptunium concentration (see Table XIII). The neptunium removal rate increased with an increase in the temperature. Plutonium removal rates, but not strontium exhibited a similar behavior (see Tables XII and XI). For both plutonium and neptunium, the rates exhibited larger increases between $25^{\circ} \mathrm{C}$ and $45^{\circ} \mathrm{C}$ compared to $45^{\circ} \mathrm{C}$ and $65^{\circ} \mathrm{C}$ in the high activity solutions.

\title{
Table XIII. Incremental Removal Rates for Neptunium Upon Reaching Np-237 Limit for Feed of Decontaminated Salt Solution to Z-Area
}

\author{
Incremental Rate $(\mu \mathrm{g} / \mathrm{L}-\mathrm{h})^{\mathrm{a}}$

\begin{tabular}{|c|c|c|c|c|}
\hline \multirow[b]{3}{*}{ Temp. $\left({ }^{\circ} \mathrm{C}\right)$} & \multicolumn{4}{|c|}{ Laverilutal Ra } \\
\hline & $4.5 \mathrm{I}$ & $1 \mathrm{Na}^{+}$ & $7.5 \mathrm{I}$ & \\
\hline & Low Activity & High Activity & Low Activity & High Activity \\
\hline 25 & 33.6 & exceeded limit & exceeded limit & exceeded limit \\
\hline 45 & 130 & exceeded limit & exceeded limit & exceeded limit \\
\hline 65 & 155 & exceeded limit & exceeded limit & exceeded limit \\
\hline
\end{tabular} \\ ${ }^{\mathrm{a}}$ incremental rate determined for the time period during which the neptunium concentration passed \\ through the Z-Area Np-237 limit $\left(0.03 \mathrm{nCi} / \mathrm{g}-51 \mu \mathrm{g} / \mathrm{L}\right.$ for $4.5 \mathrm{M} \mathrm{Na}^{+}$solutions and $56 \mu \mathrm{g} / \mathrm{L}$ for $7.5 \mathrm{M}$ \\ $\mathrm{Na}^{+}$solutions) for decontaminated salt solution.
}

Batch Removal of Strontium, Plutonium. Uranium and Neptunium

An alternative facility design would achieve strontium and actinide removal in a feed preparation tank in the tank farm or in a separate batch tank preceding the tetraphenylborate precipitation tanks or the crystalline silicotitanate ion-exchange column in the salt processing facility. In these options, the sodium ion concentration in the feed solution could be as high as $7.5 \mathrm{M}$. Thus, design evaluation efforts require an understanding of the effect of ionic strength on removal rate. From inspection of the plots of sorbate concentration versus time (Figures 5-20), we determined the sampling interval during which the test had achieved equilibrium for the solutions at 4.5 and $7.5 \mathrm{M}^{\text {in }} \mathrm{Na}^{+}$and treated with $0.2 \mathrm{~g} / \mathrm{L}$ MST. Table XIV presents these times.

Table XIV. Estimated Times from Sampling Intervals to Reach Equilibrium

\begin{tabular}{|c|c|c|c|c|}
\hline \multirow[b]{2}{*}{ Adsorbate } & \multicolumn{3}{|c|}{ Time $(\mathrm{h})^{\mathrm{a}}$} & \multirow[b]{2}{*}{$7.5 \mathrm{M} \mathrm{High}$} \\
\hline & $4.5 \mathrm{M} \mathrm{Low}$ & $7.5 \mathrm{M} \mathrm{Low}$ & $4.5 \mathrm{M} \mathrm{High}$ & \\
\hline $\mathrm{Sr}$ & 8.6 & 49 & 8.5 & 8.3 \\
\hline $\mathrm{Pu}$ & 8.6 & 50 & 25 & 25 \\
\hline $\mathrm{Np}$ & 25 & 50 & 25 & 170 \\
\hline $\mathrm{U}^{2}$ & 25 & 100 & 25 & 170 \\
\hline
\end{tabular}

For the low activity solution, increasing the ionic strength increased the time to reach equilibrium for all four sorbates. For the high activity solution, the time did not increase for strontium and 
plutonium, but did increase for neptunium and uranium. This behavior suggests that removal rates depend on the ionic strength and the initial sorbate concentration for all of the sorbates with the possible exception of strontium. We recommend additional tests be conducted with more frequent sampling to provide a more accurate determination of when equilibrium is achieved.

\section{Quality Assurance}

This work used the following task plan.

W. R. Wilmarth, D. T. Hobbs and M. G. Bronikowski, "Phase III Test Plan for MST Adsorption Kinetics," WSRC-RP-98-00736, revision 0, August 10, 1998.

This document provides the final deliverable for the work requested in the authorizing task request, P. L. Rutland, "MST Alpha Removal and Hg Removal for Salt Team Phase 3 Evaluation," HLE-TAR-98062, revision 0, July 15, 1998.

Notebooks WSRC-NB-98-00220, WSRC-NB-98-00268 and WSRC-NB-99-00061, (D. T. Hobbs) contain the experimental data obtained from this testing.

\section{Acknowledgements}

The authors thank the many people who helped bring this work to completion. M. S. Blume and H. L. Thacker conducted much of the experimental work involved in the adsorption experiments. E. A. Kyser and K. J. Kalbaugh supplied actinide materials. J. L. Siler assisted with equipment photography. The staff of the Analytical Developmental Section of the SRTC performed the many chemical and radiochemical analyses.

\section{References}

1. P. L. Rutland, "MST Alpha Removal and Hg Removal for Salt Team Phase 3 Evaluation," HLETAR-98062, Rev. 0, July 15, 1998.

2. D. T. Hobbs and D. D. Walker, "Plutonium and Uranium Adsorption on Monosodium Titanate (U)," WSRC-RP-92-93, August 13, 1992.

3. D. T. Hobbs and S. D. Fleischman, "Fissile Solubility and Monosodium Titanate Loading Tests (U)," WSRC-RP-92-1273, February 12, 1993.

4. T. B. Edwards, "A Statistically Designed Experimental Plan Supporting LWP's Study of MST Adsorption Kinetics (U)," SRT-SCS-98-034, July 23, 1998.

5. D. T. Hobbs and S. D. Fleischman, "Fissile Solubility and Monosodium Titanate Loading Tests, WSRC-RP-92-1273, February 12, 1993.

6. "WSRC 241-82H Control Room Process Requirements," WSRC-IM-91-63, Rev. 20, October 1998.

7. "Chart of the Nuclides," Knolls Atomic Power Laboratory, Distributed by the General Electric Company, Schenectady, NY, October 1972.

8. N. E. Bibler, W. F. Kinard, W. T. Boyce and C. J. Coleman, "Determination of Long-Lived fission Products and Actinides in Savannah River Site HLW Sludge and Glass for Waste Acceptance," Journal of Radioanalytical and Nuclear Chemistry, 234 (1998), 159-163.

9. Memorandum from N. S. Dienes, "Plutonium Metal Feed Specification for Use in the Weapon Program Rocky Flats Plant, Volume I, Rev. A, March 22, 1985. 
10. S. J. Snyder, "Characterization of HB-Line Low Level Waste (U)," WSRC-TR-94-0371, Rev. 0, August, 1994.

11. Electronic memo from J. R. Fowler to D. T. Hobbs, April 26, 1998. A copy of the memo is provided in Appendix 9.

12. Scot Beck, et al., "Bases, Assumptions and Results of the Flowsheet Calculations for the Short List Salt Disposition Alternatives," WSRC- RP-98-00168, Rev. 1, October 1998.

13. M. G. Bronikowski, D. T. Hobbs and W. R. Wilmarth, "Preliminary Report on Monosodium Titanate Adsorption Kinetics," WSRC-TR-98-00346, Rev. 0, October 5, 1998.

14. D. T. Hobbs, "Effects of Coprecipitation on the Concentrations of Uranium and Plutonium in Alkaline Salt Solutions," WSRC-TR-95-0462, November 30, 1995.

15. D. T. Hobbs, "Precipitation of Uranium and Plutonium from Alkaline Salt Solutions," Nuclear Technology, accepted for publication. 


\section{Appendix 1. \\ Average Concentration versus Time Data for Control Samples 6.0 $\mathrm{M} \mathrm{Na}^{+}$, No Added MST \\ Low Activity Solutions - Bottles \# 09 and 12 \\ High Activity Solutions - Bottles \# 02 and 06 \\ (Units of Time $=$ hours; Units of Concentration $=\mu \mathrm{g} / \mathrm{L}$ )}

Average of Blank Botles 49 and $\# 12$ (6.0 M, Low Activity, no MST)

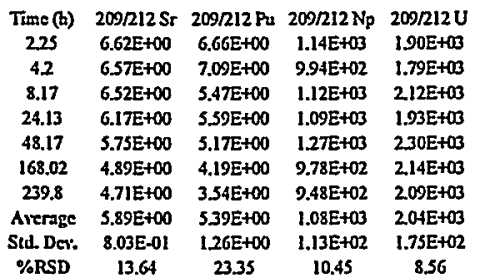

\begin{tabular}{|c|c|c|c|c|}
\hline $\begin{array}{c}\text { Time (h) } \\
2.2\end{array}$ & $\begin{array}{c}609 / 612 \mathrm{Sr} \\
6.26 \mathrm{E}+00\end{array}$ & $\begin{array}{c}609 / 612 \mathrm{Pu} \\
6.19 \mathrm{E}-01\end{array}$ & $\begin{array}{c}609 / 612 \mathrm{~Np} \\
4,27 \mathrm{E}+02\end{array}$ & $\begin{array}{l}609 / 612 \mathrm{U} \\
1.92 \mathrm{E}+13 \mathrm{~S}\end{array}$ \\
\hline 42 & $6.26 E+00$ & $5.00 \mathrm{E}-01$ & $4.32 E+02$ & 2.11E+03 \\
\hline 8.23 & $19 E+\infty$ & $3.65 \mathrm{E}-01$ & 3.78E+02 & 1.81E+03 \\
\hline 24.1 & $72 E+60$ & 2.05E-0I & $339 E+02$ & $1.78 E+03$ \\
\hline 48.1 & $4.32 E+00$ & $1.28 \mathrm{E}-0 \mathrm{I}$ & 3.03E+02 & $1.84 E+03$ \\
\hline 26.07 & $3.73 E+\infty$ & G.07E-02 & $2.02 E+02$ & $1.79 E+03$ \\
\hline 167.88 & $337 E+\infty 0$ & $5.62 \mathrm{E}-02$ & $2,69 E+02$ & $1,64 E+03$ \\
\hline Average & $4.98 E+00$ & 2.76E-01 & $350 \mathrm{E}+02$ & $1.84 E+03$ \\
\hline Std. Des: & $1.25 E+00$ & 2.23E-01 & $.45 E+01$ & $1.48 E+02$ \\
\hline & & & 48 & \\
\hline
\end{tabular}

Average of Botules $\# 2$ and $\# 6$ (6.0 M, High Activity, no MST)

\begin{tabular}{|c|c|c|c|c|}
\hline $\begin{array}{l}\text { Tixe (b) } \\
1.05\end{array}$ & $\begin{array}{c}202206 \mathrm{Sr} \\
8.60 \mathrm{E}+01\end{array}$ & $\begin{array}{c}2022206 \mathrm{Pu} \\
2.22 \mathrm{E}+02\end{array}$ & $\begin{array}{c}202 / 206 \mathrm{~Np} \\
3.01 \mathrm{E}+04\end{array}$ & $\begin{array}{l}202 / 206 \mathrm{U} \\
2.09 \mathrm{E}+04\end{array}$ \\
\hline 4.13 & $8.58 E+01$ & $200 E+02$ & 2.65E+04 & 2.00E+04 \\
\hline 8.07 & $8.45 E+01$ & $220 E+02$ & $2.96 \mathrm{E}+04$ & 2.01E+04 \\
\hline 24.07 & $8.42 E+01$ & $1.84 \mathrm{E}+02$ & $2.53 E+04$ & $1.78 E+04$ \\
\hline 48.10 & $836 E+01$ & $2.03 \mathrm{E}+02$ & 275E+04 & 1.91E+04 \\
\hline 168.32 & $8.44 E+01$ & $2.19 E+02$ & 2.86E+04 & $1.97 E+04$ \\
\hline 23938 & 8.64E+01 & $2.07 E+02$ & 2.88E+04 & $2.04 E+04$ \\
\hline Average & $8.50 E+01$ & $2,08 E+02$ & 2.81E+04 & $1.97 E+04$ \\
\hline Std. Dev. & $1.06 E+00$ & $138 \mathrm{E}+0 \mathrm{l}$ & $1.69 E+03$ & $1.03 E+03$ \\
\hline \%RSD & 125 & 6.62 & 6.02 & 5.22 \\
\hline
\end{tabular}

$\begin{array}{ccccc}\text { Time (h) } & 409 / 412 \mathrm{Sr} & 409 / 412 \mathrm{Pu} & 409 / 412 \mathrm{~Np} & 409 / 412 \mathrm{U} \\ 2.22 & 6.62 \mathrm{E}+00 & 1.82 \mathrm{E}+00 & 7.07 \mathrm{E}+02 & 2.25 \mathrm{E}+03 \\ 4.22 & 6.56 \mathrm{E}+00 & 1.39 \mathrm{E}+00 & 7.30 \mathrm{E}+02 & 2.27 \mathrm{E}+03 \\ 8.22 & 6.34 \mathrm{E}+00 & 1.22 \mathrm{E}+00 & 5.90 \mathrm{E}+02 & 1.94 \mathrm{E}+03 \\ 24.33 & 5.49 \mathrm{E}+00 & 1.20 \mathrm{E}+00 & 5.56 \mathrm{E}+02 & 2.13 \mathrm{E}+03 \\ 48.22 & 4.96 \mathrm{E}+00 & 9.95 \mathrm{E}-01 & 5.08 \mathrm{E}+02 & 2.13 \mathrm{E}+03 \\ 95.7 & 3.93 \mathrm{E}+00 & 5.87 \mathrm{E}-01 & 4.29 \mathrm{E}+02 & 1.94 \mathrm{E}+03 \\ 168.02 & 1.84 \mathrm{E}+00 & 5.12 \mathrm{E}-01 & 3.68 \mathrm{E}+02 & 1.94 \mathrm{E}+03 \\ \text { Average } & 5.11 \mathrm{E}+00 & 1.10 \mathrm{E}+00 & 5.56 \mathrm{E}+02 & 2.09 \mathrm{E}+03 \\ \text { StL. Dev. } & 1.74 \mathrm{E}+00 & 4.57 \mathrm{E}-01 & 134 \mathrm{E}+02 & 1.45 \mathrm{E}+02 \\ \text { \%RSD } & 34.09 & 41.37 & 24.13 & 6.97\end{array}$


Appendix 2.

Strontium Concentrations in Control Samples
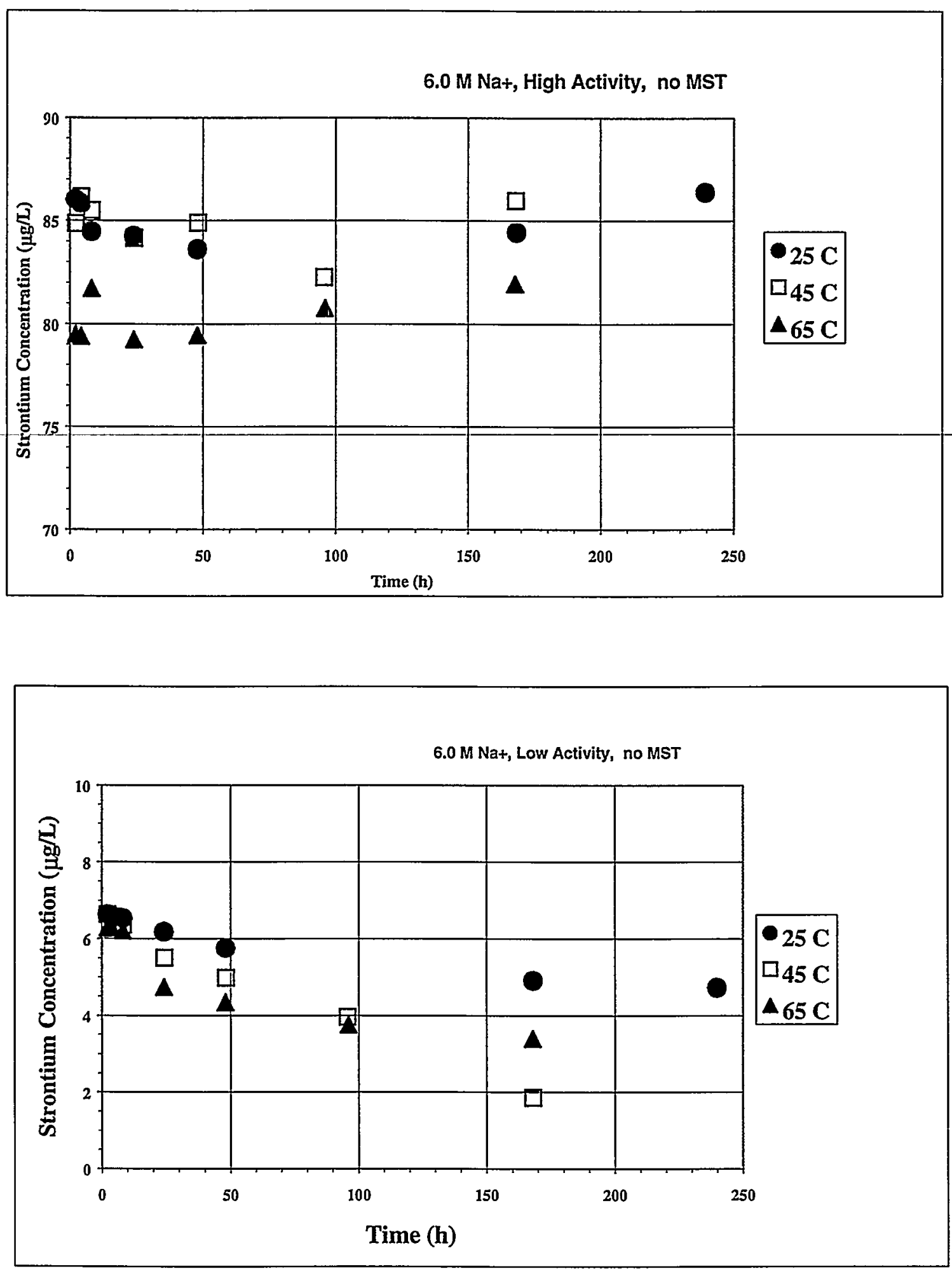

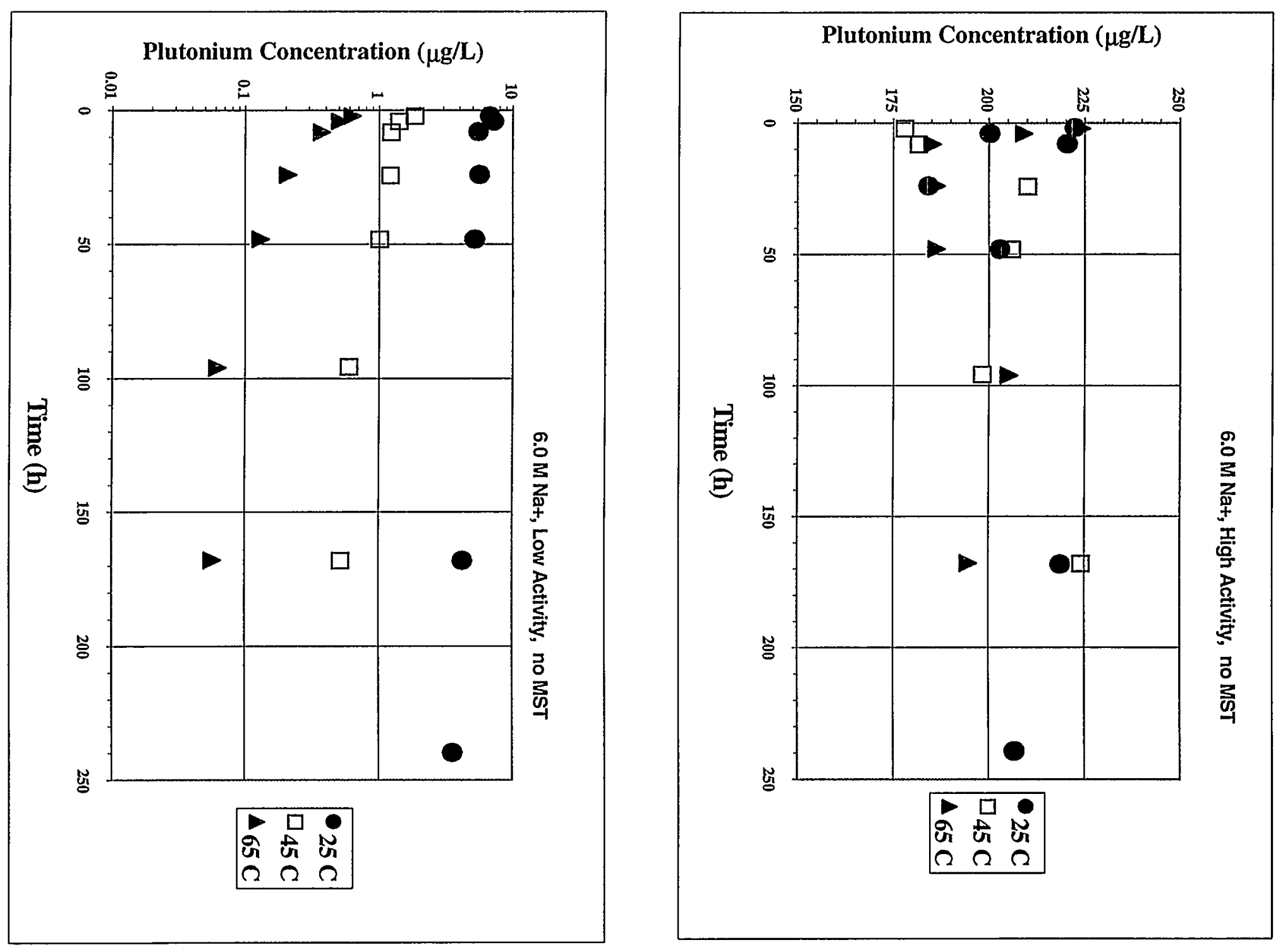

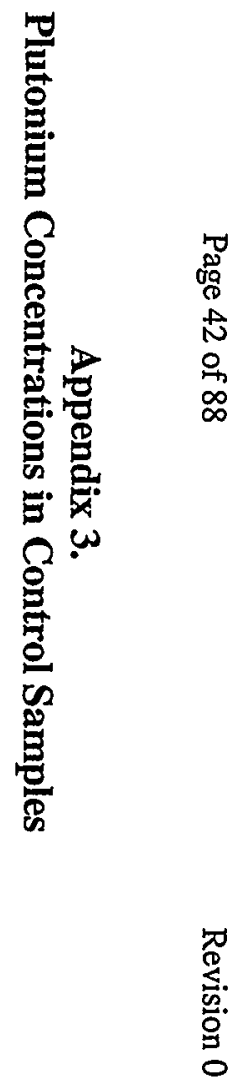


Appendix 4.

Uranium Concentration in Control Samples
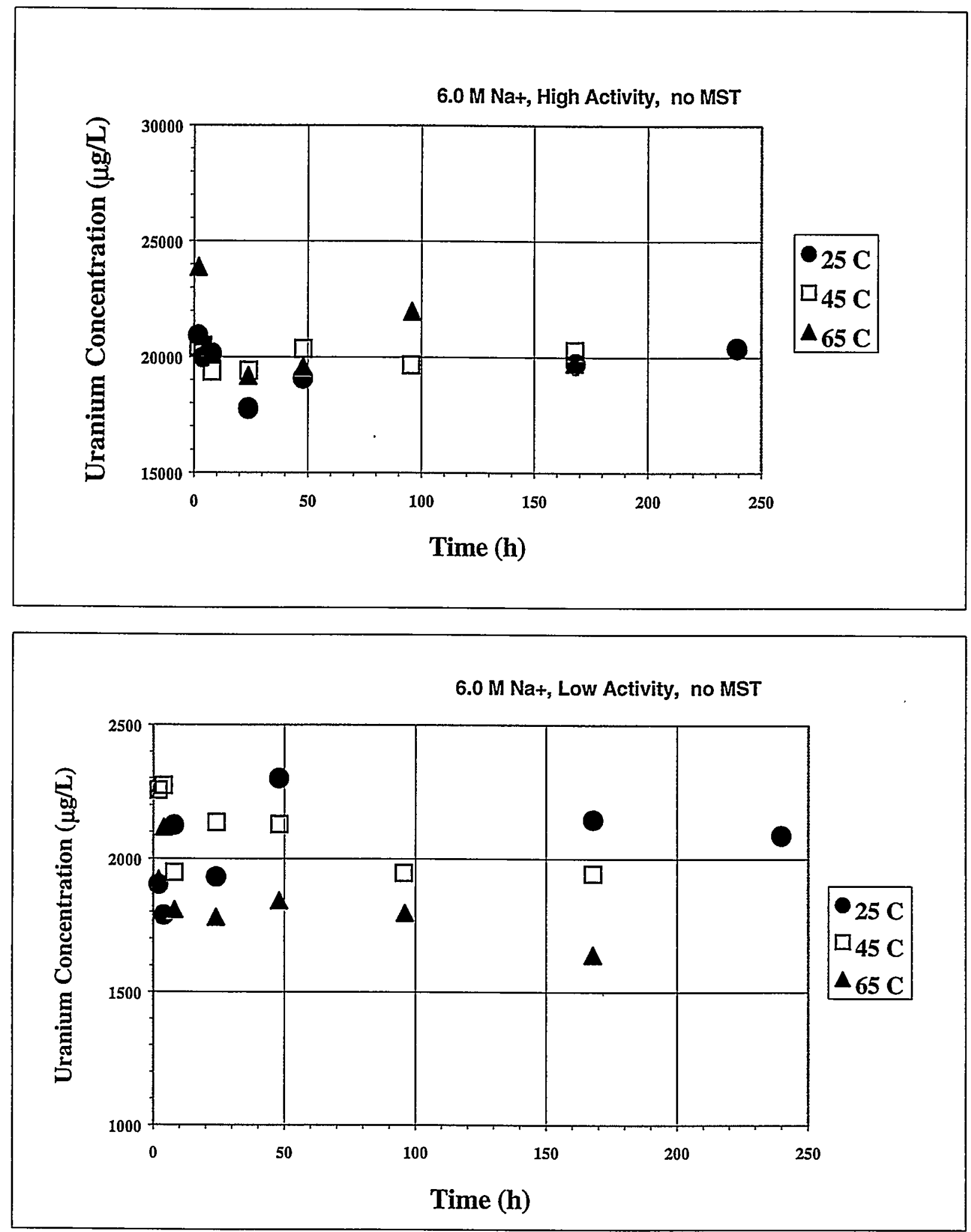

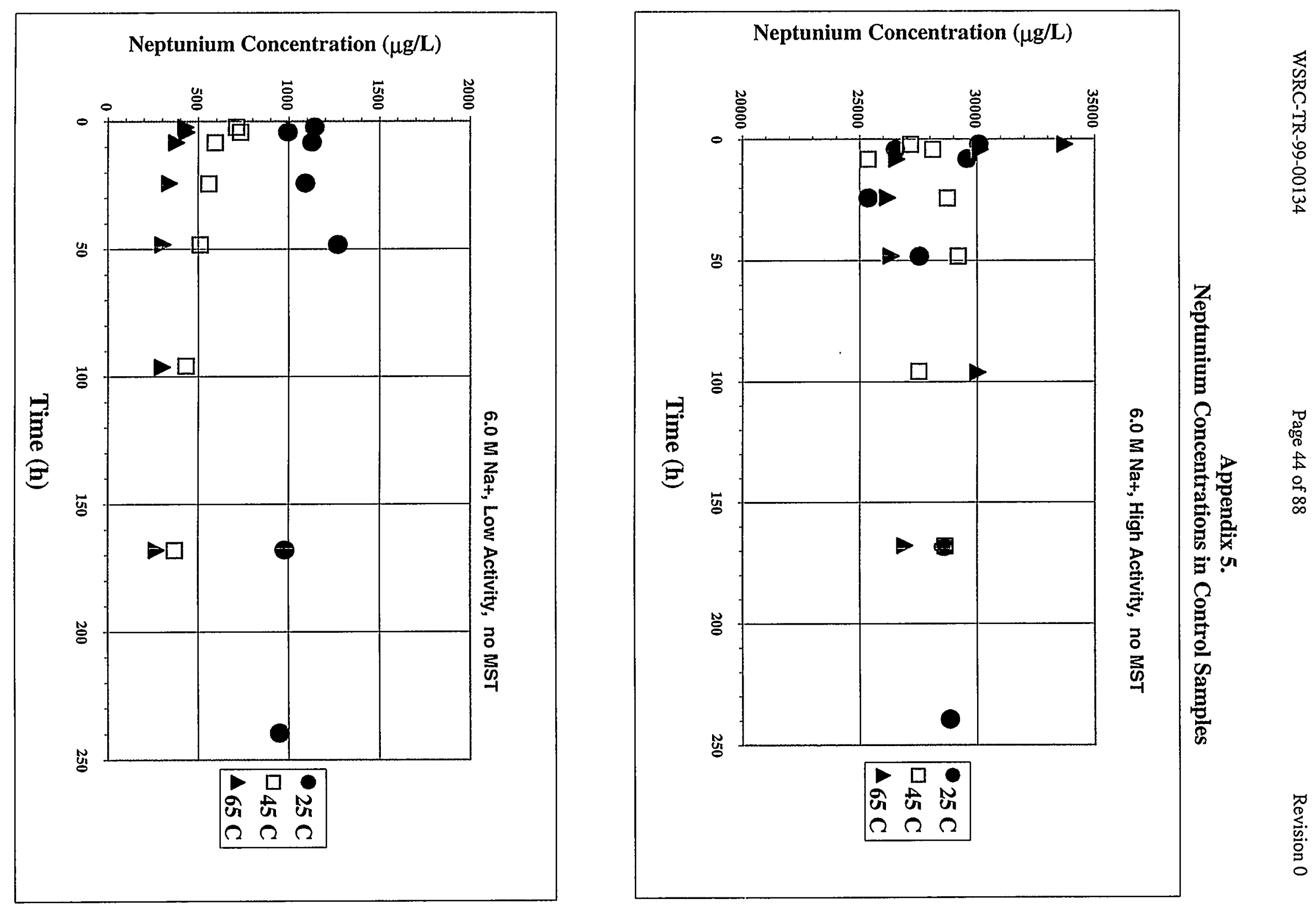


\section{Appendix 6.}

\section{Equilibrium Distribution Constants at $25^{\circ} \mathrm{C}$}

\begin{tabular}{|c|c|c|c|c|c|c|c|c|c|c|c|c|c|}
\hline $\begin{array}{c}\text { Bottle } \\
\text { Number }\end{array}$ & $\begin{array}{c}{[\mathrm{Na}+]} \\
(\mathrm{M})\end{array}$ & $\begin{array}{c}\mathbf{Z} \\
(\mathbf{M}) \\
\end{array}$ & $\begin{array}{c}\text { [MST] } \\
(\mathrm{g} / \mathrm{L})\end{array}$ & Activity & $\begin{array}{l}\text { Special } \\
\text {. Note }\end{array}$ & $\begin{array}{c}{[\mathrm{Sr}] 0} \\
(\mu \mathrm{g} / \mathrm{L})\end{array}$ & $\begin{array}{l}{[\mathrm{Pu}] 0} \\
(\mu \mathrm{g} / \mathrm{L})\end{array}$ & $\begin{array}{c}{[U]_{0}} \\
(\mu g / L)\end{array}$ & $\begin{array}{l}{[\mathrm{Np}] \mathrm{o}} \\
(\mu \mathrm{g} / \mathrm{L})\end{array}$ & $\begin{array}{r}\mathrm{Kd} \mathrm{Sr} \\
(\mathrm{mL} / \mathrm{g}) \\
\end{array}$ & $\begin{array}{l}\mathrm{Kd} \mathrm{Pu} \\
(\mathrm{mL} / \mathrm{g})\end{array}$ & $\begin{array}{c}\mathbf{K d} \mathbf{U} \\
(\mathrm{mL} / \mathrm{g}) \\
\end{array}$ & $\begin{array}{l}\mathrm{Kd} \mathrm{Np} \\
(\mathrm{mL} / \mathrm{g}) \\
\end{array}$ \\
\hline 7 & 6.0 & 6.55 & 1.1 & high & & $8.48 \mathrm{E}+01$ & $2.23 \mathrm{E}+02$ & $1.97 \mathrm{E}+04$ & $2.80 \mathrm{E}+04$ & $1.33 E+06$ & $>9.4 \mathrm{E} 4$ & $1.58 \mathrm{E}+03$ & $6.97 \mathrm{E}+02$ \\
\hline 32 & 6.0 & 6.55 & 1.1 & high & & $8.48 \mathrm{E}+01$ & $2.23 E+02$ & $1.97 \mathrm{E}+04$ & $2.80 \mathrm{E}+04$ & $1.95 \mathrm{E}+06$ & $>9.4 \mathrm{E} 4$ & $1.22 \mathrm{E}+03$ & $4.96 \mathrm{E}+02$ \\
\hline 3 & 6.0 & 6.55 & 1.1 & high & a & $8.48 \mathrm{E}+01$ & $2.23 \mathrm{E}+02$ & $1.97 E+04$ & $2.80 \mathrm{E}+04$ & $8.42 E+05$ & $>9.4 \mathrm{E} 4$ & $1.32 \mathrm{E}+03$ & $5.67 \mathrm{E}+02$ \\
\hline 13 & 6.0 & 6.55 & 1.1 & high & a & $8.48 \mathrm{E}+01$ & $2.23 E+02$ & $1.97 \mathrm{E}+04$ & $2.80 \mathrm{E}+04$ & $7.41 E+05$ & $>9.4 \mathrm{E} 4$ & $1.08 \mathrm{E}+03$ & $4.63 \mathrm{E}+02$ \\
\hline 5 & 6.0 & 6.55 & 1.1 & high & b & $8.48 \mathrm{E}+01$ & $2.23 \mathrm{E}+02$ & $1.97 E+04$ & $2.80 \mathrm{E}+04$ & $7.01 \mathrm{E}+05$ & $>9.4 \mathrm{E} 4$ & $1.55 \mathrm{E}+03$ & $6.90 \mathrm{E}+02$ \\
\hline 19 & 6.0 & 6.55 & 1.1 & high & c & $8.48 \mathrm{E}+01$ & $2.23 \mathrm{E}+02$ & $1.97 \mathrm{E}+04$ & $2.80 \mathrm{E}+04$ & $8.29 E+05$ & $>9.4 \mathrm{E} 4$ & $1.05 \mathrm{E}+03$ & $1.03 E+03$ \\
\hline 10 & 6.0 & 6.55 & 1.1 & low & & $6.62 \mathrm{E}+00$ & $6.66 \mathrm{E}+00$ & $2.04 \mathrm{E}+03$ & $1.08 \mathrm{E}+03$ & $1.57 \mathrm{E}+05$ & $1.55 \mathrm{E}+04$ & $2.23 \mathrm{E}+04$ & $5.68 \mathrm{E}+04$ \\
\hline 24 & 6.0 & 6.55 & 1.1 & low & & $6.62 \mathrm{E}+00$ & $6.66 \mathrm{E}+00$ & $2.04 \mathrm{E}+03$ & $1.08 \mathrm{E}+03$ & $1.48 \mathrm{E}+0.5$ & $1.46 \mathrm{E}+04$ & $2.03 E \div 04$ & $4.83 \mathrm{E}+04$ \\
\hline 16 & 6.0 & 6.55 & 1.1 & low & a & $6.62 \mathrm{E}+00$ & $6.66 \mathrm{E}+00$ & $2.04 \mathrm{E}+03$ & $1.08 \mathrm{E}+03$ & $1.08 \mathrm{E}+05$ & $8.98 \mathrm{E}+03$ & $1.84 \mathrm{E}+04$ & $4.17 E+04$ \\
\hline 26 & 6.0 & 6.55 & 1.1 & low & a & $6.62 \mathrm{E}+00$ & $6.66 \mathrm{E}+00$ & $2.04 \mathrm{E}+03$ & $1.08 \mathrm{E}+03$ & $1.38 \mathrm{E}+05$ & $1.07 E+04$ & $1.95 \mathrm{E}+04$ & $5.07 \mathrm{E}+04$ \\
\hline 21 & 6.0 & 6.55 & 1.1 & low & b & $6.62 \mathrm{E}+00$ & $6.66 \mathrm{E}+00$ & $2.04 \mathrm{E}+03$ & $1.08 \mathrm{E} \div 03$ & $1.27 \mathrm{E}+05$ & $1.59 \mathrm{E} \div 04$ & $2.00 \mathrm{E}+04$ & $4.23 \mathrm{E}+04$ \\
\hline 14 & 6.0 & 6.55 & 1.1 & low & c & $6.62 \mathrm{E}+00$ & $6.66 \mathrm{E}+00$ & $2.04 \mathrm{E}+03$ & $1.08 \mathrm{E}+03$ & $2.59 E+05$ & $1.34 \mathrm{E}+05$ & $2.13 E+04$ & $>4.85 \mathrm{E}+05$ \\
\hline 22 & 4.5 & 4.91 & 0.2 & low & & $4.96 \mathrm{E}+00$ & $1.12 \mathrm{E}+00$ & $1.52 \mathrm{E}+03$ & $3.40 \mathrm{E}+02$ & $1.58 \mathrm{E}+05$ & $3.35 \mathrm{E}+04$ & $7.68 \mathrm{E}+03$ & $8.55 E+04$ \\
\hline 25 & 4.5 & 4.91 & 0.2 & low & & $4.96 \mathrm{E}+00$ & $1.12 E+00$ & $1.52 \mathrm{E}+03$ & $3.40 \mathrm{E}+02$ & $1.58 \mathrm{E}+05$ & $3.93 E+04$ & $4.24 E+03$ & $6.69 \mathrm{E}+04$ \\
\hline 11 & 4.5 & 4.91 & 0.2 & high & & $6.36 \mathrm{E}+01$ & $1.68 \mathrm{E}+02$ & $1.48 \mathrm{E}+04$ & $2.10 \mathrm{E}+04$ & $1.72 \mathrm{E}+06$ & $>2.4 \mathrm{E}+05$ & $7.93 \mathrm{E}+02$ & $1.92 \mathrm{E}+03$ \\
\hline 31 & 4.5 & 4.91 & 0.2 & high & & $6.36 \mathrm{E}+01$ & $1.68 \mathrm{E}+02$ & $1.48 \mathrm{E}+04$ & $2.10 \mathrm{E}+04$ & $1.92 \mathrm{E}+06$ & $>2.0 \mathrm{E}+05$ & $1.20 \mathrm{E}+03$ & $2.46 \mathrm{E}+03$ \\
\hline 15 & 7.5 & 8.20 & 0.2 & low & & $8.28 E+00$ & $9.83 E+00$ & $2.56 \mathrm{E}+03$ & $1.70 \mathrm{E}+03$ & $2.59 \mathrm{E}+04$ & $1.17 E+03$ & $1.74 \mathrm{E}+03$ & $1.12 \mathrm{E}+04$ \\
\hline 18 & 7.5 & 8.20 & 0.2 & low & & $8.28 \mathrm{E}+00$ & $9.83 \mathrm{E}+00$ & $2.56 \mathrm{E}+03$ & $1.70 \mathrm{E}+03$ & $2.48 \mathrm{E}+04$ & $1.10 \mathrm{E}+03$ & $2.19 E+03$ & $1.28 \mathrm{E}+04$ \\
\hline 1 & 7.5 & 8.20 & 0.2 & high & & $1.06 \mathrm{E}+02$ & $2.80 \mathrm{E}+02$ & $2.46 E+04$ & $3.50 \mathrm{E}+04$ & $3.95 \mathrm{E}+05$ & $>3.4 \mathrm{E}+05$ & $3.17 \mathrm{E}+03$ & $3.31 \mathrm{E}+03$ \\
\hline 28 & 7.5 & 8.20 & 0.2 & high & & $1.06 \mathrm{E}+02$ & $2.80 \mathrm{E}+02$ & $2.46 \mathrm{E}+04$ & $3.50 \mathrm{E}+04$ & $3.91 E+05$ & $>3.4 \mathrm{E}+05$ & $4.04 E+03$ & $3.96 \mathrm{E}+03$ \\
\hline 4 & 4.5 & 4.91 & 2.0 & & & $4.96 \mathrm{E}+00$ & $1.12 \mathrm{E}+00$ & $1.52 \mathrm{E}+03$ & $3.40 \mathrm{E}+02$ & $3.42 \mathrm{E}+05$ & $5.56 \mathrm{E}+03$ & $>3.8 \mathrm{E}+05$ & $>8.4 E+04$ \\
\hline 30 & 4.5 & 4.91 & 2.0 & low & & $4.96 \mathrm{E}+00$ & $1.12 \mathrm{E}+00$ & $1.52 \mathrm{E}+03$ & $3.40 \mathrm{E}+02$ & $1.01 E+05$ & $2.65 \mathrm{E}+03$ & $>6.5 \mathrm{E}+04$ & $>8.4 \mathrm{E}+04$ \\
\hline 20 & 4.5 & 4.91 & 2.0 & high & & $6.36 \mathrm{E}+01$ & $1.68 \mathrm{E}+02$ & $1.48 \mathrm{E}+04$ & $2.10 E+04$ & $1.84 \mathrm{E}+06$ & $>2.0 \mathrm{E}+04$ & 3.37E+03 & $6.27 E+02$ \\
\hline 29 & 4.5 & 4.91 & 2.0 & high & & $6.36 \mathrm{E}+01$ & $1.68 \mathrm{E} \div 02$ & $1.48 \mathrm{E}+04$ & $2.10 \mathrm{E}+04$ & $>5.8 \mathrm{E}+05$ & $>2.0 \mathrm{E}+04$ & $3.45 E+03$ & $6.72 \mathrm{E}+02$ \\
\hline 8 & 7.5 & 8.20 & 2.0 & low & & $8.28 \mathrm{E}+00$ & $9.83 \mathrm{E}+00$ & $2.56 \mathrm{E}+03$ & $1.70 E+03$ & $3.58 \mathrm{E} \div 04$ & $1.63 \mathrm{E}+03$ & $7.46 \mathrm{E}+04$ & $8.41 E+04$ \\
\hline 23 & 7.5 & 8.20 & 2.0 & low & & $8.28 \mathrm{E}+00$ & $9.83 \mathrm{E}+00$ & $2.56 \mathrm{E}+03$ & $1.70 \mathrm{E}+03$ & $3.41 \mathrm{E}+04$ & $1.76 \mathrm{E}+03$ & $9.08 E+04$ & $8.53 E+04$ \\
\hline 17 & 7.5 & 8.20 & 2.0 & high & & $1.06 \mathrm{E}+$ & $2.80 \mathrm{E}+02$ & $2.46 \mathrm{E}+04$ & $3.50 \mathrm{E}+04$ & $2.03 \mathrm{E}+05$ & $>3.4 \mathrm{E}+04$ & $2.08 \mathrm{E}+03$ & $4.81 \mathrm{E}+02$ \\
\hline 27 & 7.5 & 8.20 & 2.0 & high & & $1.06 \mathrm{E}+02$ & $2.80 \mathrm{E}+02$ & $2.46 \mathrm{E}+04$ & $3.50 \mathrm{E}+04$ & $3.30 \mathrm{E}+05$ & $>3.4 \mathrm{E}+04$ & $1.98 \mathrm{E}+03$ & $4.42 E+02$ \\
\hline
\end{tabular}

Special Note: $\mathrm{a}=$ unmixed $\mathrm{b}=400 \mathrm{mg} / \mathrm{L}$ NaTPB $c=400 \mathrm{mg} / \mathrm{L}$ sludge 


\section{Appendix 7.}

\section{Equilibrium Distribution Constants at $45^{\circ} \mathrm{C}$}

\begin{tabular}{|c|c|c|c|c|c|c|c|c|c|c|c|c|c|}
\hline $\begin{array}{l}\text { Bottle } \\
\text { Number }\end{array}$ & $\begin{array}{c}{[\mathrm{Na}+]} \\
(\mathrm{M})\end{array}$ & $\begin{array}{c}Z \\
(M)\end{array}$ & $\begin{array}{c}{[\mathrm{MST}]} \\
(\mathrm{g} / \mathrm{L})\end{array}$ & Activity & $\begin{array}{c}\text { Special } \\
\text { Note }\end{array}$ & $\begin{array}{c}{[S r] 0} \\
(\mu \mathrm{g} / \mathrm{L}) \\
\end{array}$ & $\begin{array}{c}\text { [Pu }] 0 \\
(\mu \mathrm{g} / \mathrm{L}) \\
\end{array}$ & $\begin{array}{c}{[\mathrm{U}]_{0}} \\
(\mu \mathrm{g} / \mathrm{L})\end{array}$ & $\begin{array}{l}{[N p] 0} \\
(\mu g / L)\end{array}$ & $\begin{array}{c}\mathrm{Kd} \mathrm{Sr} \\
(\mathrm{mL} / \mathrm{g})\end{array}$ & $\begin{array}{l}\mathrm{Kd} \mathrm{Pu} \\
(\mathrm{mL} / \mathrm{g})\end{array}$ & $\begin{array}{c}\mathbf{K d} \mathbf{U} \\
(\mathrm{mL} / \mathrm{g}) \\
\end{array}$ & $\begin{array}{l}\text { Kd Np } \\
(\mathrm{mL} / \mathrm{g}) \\
\end{array}$ \\
\hline 7 & 6.0 & 6.55 & 1.1 & high & & $7.22 \mathrm{E}+01$ & $2.14 \mathrm{E}+02$ & $2.00 \mathrm{E}+04$ & $2.78 \mathrm{E}+04$ & $1.88 \mathrm{E}+06$ & $>8.97 \mathrm{E}+04$ & $1.63 \mathrm{E}+03$ & $1.69 \mathrm{E}+03$ \\
\hline 32 & 6.0 & 6.55 & 1.1 & high & & $7.22 \mathrm{E}+01$ & $2.14 \mathrm{E}+02$ & $2.00 \mathrm{E}+04$ & $2.78 \mathrm{E}+04$ & $2.22 \mathrm{E}+06$ & $>8.97 E+04$ & $1.89 \mathrm{E}+03$ & $1.33 E+03$ \\
\hline 3 & 6.0 & 6.55 & 1.1 & high & a & $7.22 \mathrm{E}+01$ & $2.14 \mathrm{E}+02$ & $2.00 \mathrm{E}+04$ & $2.78 \mathrm{E}+04$ & $1.10 \mathrm{E}+06$ & $>8.97 E+04$ & $1.61 E+03$ & $1.24 \mathrm{E}+03$ \\
\hline 13 & 6.0 & 6.55 & 1.1 & high & a & $7.22 \mathrm{E}+01$ & $2.14 \mathrm{E}+02$ & $2.00 \mathrm{E}+04$ & $2.78 \mathrm{E}+04$ & $1.05 E+06=$ & $>8.97 \mathrm{E}+04$ & $1.64 \mathrm{E} \div 03$ & $1.37 \mathrm{E}+03$ \\
\hline 5 & 6.0 & 6.55 & 1.1 & high & b & $7.22 \mathrm{E}+01$ & $2.14 \mathrm{E}+02$ & $2.00 \mathrm{E}+04$ & $2.78 \mathrm{E}+04$ & $1.29 \mathrm{E}+06$ & $>8.97 E+04$ & $1.60 \mathrm{E}+03$ & $1.73 \mathrm{E}+03$ \\
\hline 19 & 6.0 & 6.55 & 1.1 & high & c & $7.22 \mathrm{E}+01$ & $2.14 \mathrm{E}+02$ & $2.00 \mathrm{E}+04$ & $2.78 \mathrm{E}+04$ & $6.25 \mathrm{E}+05$ & $>8.97 \mathrm{E}+04$ & $1.30 \mathrm{E}+03$ & $1.33 \mathrm{E}+03$ \\
\hline 10 & 6.0 & 6.55 & 1.1 & low & & $6.62 \mathrm{E}+00$ & $7.50 \mathrm{E}-01$ & $2.08 \mathrm{E}+03$ & $7.82 \mathrm{E}+02$ & $9.32 \mathrm{E}+04$ & $2.10 \mathrm{E} \div 03$ & $2.17 \mathrm{E}+04$ & $>1.67 \mathrm{E}+05$ \\
\hline 24 & 6.0 & 6.55 & 1.1 & low & & $6.62 \mathrm{E}+00$ & $7.50 \mathrm{E}-01$ & $2.08 \mathrm{E}+03$ & $7.82 \mathrm{E}+02$ & $1.02 E+05$ & $1.95 \mathrm{E}+03$ & $1.84 E+04$ & $>1.67 \mathrm{E}+05$ \\
\hline 16 & 6.0 & 6.55 & 1.1 & low & a & $6.62 E+00$ & $7.50 \mathrm{E}-01$ & $2.08 \mathrm{E}+03$ & $7.82 \mathrm{E}+02$ & $8.51 \mathrm{E}+04$ & $8.27 E+02$ & $2.12 \mathrm{E}+04$ & $>1.67 \mathrm{E}+05$ \\
\hline 26 & 6.0 & 6.55 & 1.1 & low & a & $6.62 \mathrm{E}+00$ & $7.50 \mathrm{E}-01$ & $2.08 \mathrm{E}+03$ & $7.82 \mathrm{E}+02$ & $7.93 \mathrm{E}+04$ & $1.02 \mathrm{E}+03$ & $1.75 \mathrm{E}+04$ & $>1.67 \mathrm{E}+05$ \\
\hline 21 & 6.0 & 6.55 & 1.1 & low & b & $6.62 \mathrm{E}+00$ & $7.50 \mathrm{E}-01$ & $2.08 \mathrm{E}+03$ & $7.82 \mathrm{E}+02$ & $9.68 \mathrm{E}+04$ & $5.14 \mathrm{E}+03$ & $1.78 \mathrm{E}+04$ & $>1.67 \mathrm{E}+0$ \\
\hline 14 & 6.0 & 6.55 & 1.1 & low & c & $6.62 \mathrm{E}+00$ & $7.50 \mathrm{E}-01$ & $2.08 E+03$ & $7.82 \mathrm{E}+02$ & $8.45 \mathrm{E}+04$ & $7.53 \mathrm{E}+03$ & $1.68 \mathrm{E}+04$ & $>1.67 \mathrm{E}+\mathrm{C}$ \\
\hline 22 & 4.5 & 4.91 & 0.2 & low & & $4.98 \mathrm{E}+00$ & $1.74 \mathrm{E}+00$ & $1.56 \mathrm{E}+03$ & $5.88 \mathrm{E}+02$ & $1.75 \mathrm{E} \div 05$ & $5.63 \mathrm{E}+04$ & $7.88 \mathrm{E}+03$ & $1.07 \mathrm{E}+05$ \\
\hline 25 & 4.5 & 4.91 & 0.2 & low & & $4.98 \mathrm{E}+00$ & $1.74 \mathrm{E}+00$ & $1.56 \mathrm{E}+03$ & $5.88 \mathrm{E}+02$ & $9.85 \mathrm{E} \div 04$ & $3.12 \mathrm{E}+04$ & $8.10 \mathrm{E}+03$ & $>6.88 \mathrm{E}+0 \mathrm{~s}$ \\
\hline 11 & 4.5 & 4.91 & 0.2 & high & & $5.42 \mathrm{E}+01$ & $1.61 \mathrm{E}+02$ & $1.50 \mathrm{E}+04$ & $2.10 \mathrm{E}+04$ & $9.97 \mathrm{E}+05$ & $>3.70 \mathrm{E}+05$ & $1.22 \mathrm{E}+03$ & $5.39 \mathrm{E}+03$ \\
\hline 31 & 4.5 & 4.91 & 0.2 & high & & $5.42 \mathrm{E}+01$ & $1.61 \mathrm{E}+02$ & $1.50 \mathrm{E}+04$ & $2.10 \mathrm{E}+04$ & $9.44 \mathrm{E}+05$ & $>3.70 \mathrm{E}+0 \mathrm{~S}$ & $1.32 \mathrm{E}+03$ & $4.84 \mathrm{E}+03$ \\
\hline 15 & 7.5 & 8.20 & 0.2 & low & & $8.28 \mathrm{E}+00$ & $2.88 \mathrm{E}+00$ & $2.60 \mathrm{E} \div 03$ & $9.78 \mathrm{E}+02$ & $2.24 \mathrm{E}+04$ & $4.75 E+03$ & $3.61 \mathrm{E}+03$ & $2.00 \mathrm{E}+04$ \\
\hline 18 & 7.5 & 8.20 & 0.2 & low & & $8.28 \mathrm{E}+00$ & $2.88 \mathrm{E}+00$ & $2.60 \mathrm{E} \div 03$ & $9.78 \mathrm{E}+02$ & $2.75 \mathrm{E}+04$ & $3.35 E+03$ & $3.18 \mathrm{E}+03$ & $1.27 \mathrm{E}+04$ \\
\hline 1 & 7.5 & 8.20 & 0.2 & high & & $9.02 E \div 01$ & $2.69 \mathrm{E}+02$ & $2.50 \mathrm{E}+04$ & $3.48 \mathrm{E}+04$ & $2.83 E+05$ & $>6.20 \mathrm{E}+05$ & $2.39 E+03$ & $5.60 \mathrm{E}+03$ \\
\hline 28 & 7.5 & 8.20 & 0.2 & high & & $9.02 \mathrm{E}+01$ & $2.69 \mathrm{E}+02$ & $2.50 \mathrm{E}+04$ & $3.48 \mathrm{E}+04$ & $3.09 \mathrm{E}+05$ & $>6.20 \mathrm{E} \div 05$ & $2.96 \mathrm{E} \div 03$ & $6.30 \mathrm{E}+03$ \\
\hline 4 & 4.5 & 4.91 & 2.0 & low & & $4.98 \mathrm{E}+00$ & $1.74 \mathrm{E}+00$ & $1.56 \mathrm{E}+03$ & $5.88 \mathrm{E}+02$ & $2.80 \mathrm{E}+05$ & $3.49 \mathrm{E}+03$ & $>3.91 \mathrm{E}+05$ & $>6.88 \mathrm{E}+\mathrm{C}$ \\
\hline 30 & 4.5 & 4.91 & 2.0 & low & & $4.98 \mathrm{E}+00$ & $1.74 \mathrm{E}+00$ & $1.56 \mathrm{E}+03$ & $5.88 \mathrm{E}+02$ & $1.68 \mathrm{E} \div 05$ & $4.99 \mathrm{E}+03$ & $>3.91 \mathrm{E}+05$ & $>6.88 \mathrm{E}+$ \\
\hline 20 & 4.5 & 4.91 & 2.0 & high & & $5.42 \mathrm{E}+01$ & $1.61 \mathrm{E}+02$ & +04 & $2.10 \mathrm{E}+04$ & $8.59 \mathrm{E}+05$ & $>3.70 \mathrm{E}+04$ & $5.81 \mathrm{E}+03$ & $1.90 \mathrm{E}+03$ \\
\hline 29 & 4.5 & 4.91 & 2.0 & high & & $5.42 \mathrm{E}+01$ & $1.61 \mathrm{E}+02$ & $1.50 \mathrm{E}+04$ & $2.10 \mathrm{E}+04$ & $5.79 \mathrm{E}+05$ & $>3.70 \mathrm{E}+04$ & $6.24 \mathrm{E}+03$ & $2.18 \mathrm{E}+03$ \\
\hline 8 & 7.5 & 8.20 & 2.0 & low & & $8.28 \mathrm{E}+00$ & $2.88 \mathrm{E}$ & $2.60 \mathrm{E}$ & $9.78 \mathrm{E}+02$ & $2.13 \mathrm{E}+04$ & $1.49 E+03$ & $1.37 E+04$ & $1.20 \mathrm{E}+04$ \\
\hline 23 & 7.5 & 8.20 & 2.0 & low & & $8.28 \mathrm{E}+00$ & $2.88 \mathrm{E}+00$ & $2.60 E+03$ & $9.78 \mathrm{E}+02$ & $2.15 E+04$ & $2.09 E+03$ & $1.27 \mathrm{E}+04$ & $9.58 \mathrm{E}+03$ \\
\hline 17 & 7.5 & 8.20 & 2.0 & high & & $9.02 \mathrm{E}+01$ & $2.69 \mathrm{E}+02$ & $2.50 \mathrm{E}$ & $3.48 \mathrm{E}+04$ & $6.33 \mathrm{E}+05$ & $>6.20 \mathrm{E}+04$ & $2.82 \mathrm{E}+03$ & $1.33 \mathrm{E}+03$ \\
\hline 27 & 7.5 & 8.20 & 2.0 & high & & $9.02 E+01$ & $2.69 E+02$ & $2.50 \mathrm{E}+04$ & $3.48 \mathrm{E}+04$ & $7.77 \mathrm{E}+05$ & $>6.20 \mathrm{E}+04$ & $2.72 \mathrm{E}+03$ & $1.38 \mathrm{E}+03$ \\
\hline
\end{tabular}

Special Note: $\mathbf{a}=$ unmixed 


\section{Appendix 8}

\section{Equilibrium Distribution Constants at $65^{\circ} \mathrm{C}$}

\begin{tabular}{|c|c|c|c|c|c|c|c|c|c|c|c|c|c|}
\hline $\begin{array}{r}\text { Bottle } \\
\text { Numbe }\end{array}$ & $\begin{array}{c}{[\mathrm{Na}+]} \\
(\mathrm{M})\end{array}$ & $\begin{array}{c}\mathbf{Z} \\
(\mathrm{M})\end{array}$ & $\begin{array}{l}\text { MST } \\
(\mathrm{g} / \mathrm{L})\end{array}$ & Activity & $\begin{array}{c}\text { Special } \\
\text { Note } \\
\end{array}$ & $\begin{array}{c}{[\mathrm{Sr}] 0} \\
(\mu \mathrm{g} / \mathrm{L})\end{array}$ & $\begin{array}{l}{[\mathrm{Pu}] 0} \\
(\mu \mathrm{g} / \mathrm{L})\end{array}$ & $\begin{array}{c}{[\mathrm{U}] \mathbf{0}} \\
(\mu \mathrm{g} / \mathrm{L})\end{array}$ & $\begin{array}{l}{[\mathrm{Np}] \mathrm{o}} \\
(\mu \mathrm{g} / \mathrm{L})\end{array}$ & $\begin{array}{r}\mathrm{Kd} \mathrm{Sr} \\
(\mathrm{mL} / \mathrm{g}) \\
\end{array}$ & $\begin{array}{r}\text { Kd Pu } \\
(\mathrm{mL} / \mathrm{g}) \\
\end{array}$ & $\begin{array}{c}\mathrm{Kd} \mathbf{U} \\
(\mathrm{mL} / \mathrm{g})\end{array}$ & $\begin{array}{l}\mathrm{Kd} \mathrm{Np} \\
(\mathrm{mL} / \mathrm{g})\end{array}$ \\
\hline 7 & 6.0 & 6.55 & 1.1 & high & & $8.02 \mathrm{E}+0 \mathrm{I}$ & $2.13 \mathrm{E}+02$ & $2.08 \mathrm{E}+04$ & $2.86 \mathrm{E}+04$ & $1.76 \mathrm{E}+06$ & $>8.93 E+04$ & $1.66 \mathrm{E}+03$ & $1.13 \mathrm{E}+04$ \\
\hline 32 & 6.0 & 6.55 & 1.1 & high & & $8.02 E+01$ & $2.13 E+02$ & $2.08 E+04$ & $2.86 E+04$ & $1.01 E+06$ & $>8.93 \mathrm{E}+04$ & $1.68 \mathrm{E}+03$ & $1.18 \mathrm{E}+04$ \\
\hline 3 & 6.0 & 6.55 & 1.1 & high & a & $8.02 \mathrm{E}+01$ & $2.13 E+02$ & $2.08 E+04$ & $2.86 \mathrm{E}+04$ & $9.65 E+05$ & $>8.93 \mathrm{E}+04$ & $1.55 \mathrm{E}+03$ & $1.12 \mathrm{E}+04$ \\
\hline 13 & 6.0 & 6.55 & 1.1 & high & a & 8.02E+01 & $2.13 E+02$ & $2.08 \mathrm{E}+04$ & $2.86 \mathrm{E}+04$ & $1.07 E+06$ & $>8.93 E+04$ & $1.60 \mathrm{E}+03$ & $1.29 E+04$ \\
\hline 5 & 6.0 & 6.55 & 1.1 & high & b & $8.02 E+01$ & $2.13 E+02$ & $2.08 E+04$ & $2.86 \mathrm{E}+04$ & $7.63 E+05$ & $>8.93 \mathrm{E}+04$ & $1.72 \mathrm{E}+03$ & $1.15 \mathrm{E}+04$ \\
\hline 19 & 6.0 & 6.55 & 1.1 & high & c & $8.02 \mathrm{E}+01$ & $2.13 E+02$ & $2.08 E+04$ & $2.86 E+04$ & $5.10 \mathrm{E}+05$ & $>8.93 \mathrm{E}+04$ & $1.22 \mathrm{E}+03$ & $4.85 E+03$ \\
\hline 10 & 6.0 & 6.55 & 1.1 & low & & $6.62 \mathrm{E}+00$ & $7.50 \mathrm{E}-01$ & $1.84 \mathrm{E}+03$ & $4.72 \mathrm{E}+02$ & $5.16 E+04$ & $4.76 \mathrm{E}+03$ & $1.55 \mathrm{E}+04$ & $>4.69 \mathrm{E}+\mathrm{C}$ \\
\hline 24 & 6.0 & 6.55 & 1.1 & low & & $6.62 \mathrm{E}+00$ & $7.50 \mathrm{E}-01$ & $1.84 \mathrm{E}+03$ & $4.72 \mathrm{E}+02$ & $5.41 \mathrm{E}+04$ & $2.41 E+03$ & $1.20 \mathrm{E}+04$ & $>1.20 \mathrm{E}+0$ \\
\hline 16 & 6.0 & 6.55 & 1.1 & low & a & $6.62 \mathrm{E}+00$ & $7.50 \mathrm{E}-0 \mathrm{I}$ & $1.84 E+03$ & $4.72 E+02$ & $5.80 \mathrm{E}+04$ & $3.77 \mathrm{E}+03$ & $1.77 \mathrm{E}+04$ & $>1.20 \mathrm{E}+\mathrm{C}$ \\
\hline 26 & 6.0 & 6.55 & 1.1 & low & a & $6.62 \mathrm{E}+00$ & 7.50E-01 & $1.84 \mathrm{E}+03$ & $4.72 \mathrm{E}+02$ & $6.11 E+04$ & $2.69 E+03$ & $1.36 \mathrm{E}+04$ & $>1.20 \mathrm{E}+0$ \\
\hline 21 & 6.0 & 6.55 & 1.1 & low & b & $6.62 \mathrm{E}+00$ & $7.50 \mathrm{E}-01$ & $1.84 \mathrm{E}+03$ & $4.72 \mathrm{E}+02$ & $3.65 \mathrm{E}+04$ & $4.46 \mathrm{E}+03$ & $1.28 \mathrm{E}+04$ & $>1.20 \mathrm{E}+\mathrm{C}$ \\
\hline 14 & 6.0 & 6.55 & 1.1 & low & c & $6.62 \mathrm{E}+00$ & $7.50 \mathrm{E}-01$ & $1.84 \mathrm{E}+03$ & $4.72 E+02$ & $3.24 \mathrm{E}+04$ & $6.92 \mathrm{E}+03$ & $2.14 E+04$ & $>1.20 \mathrm{E}+\mathrm{C}$ \\
\hline 22 & 4.5 & 4.91 & 0.2 & low & & $4.98 \mathrm{E}+00$ & $5.60 \mathrm{E}-01$ & $1.38 \mathrm{E}+03$ & $3.54 \mathrm{E}+02$ & $6.47 E+04$ & $1.34 \mathrm{E}+04$ & $7.46 \mathrm{E}+03$ & $>4.92 \mathrm{E}+$ \\
\hline 25 & 4.5 & 4.91 & 0.2 & Iow & & $4.98 \mathrm{E}+00$ & $5.60 \mathrm{E}-01$ & $1.38 \mathrm{E}+03$ & $3.54 \mathrm{E}+02$ & $9.17 \mathrm{E}+04$ & $6.94 \mathrm{E}+03$ & $8.22 \mathrm{E}+03$ & $>4.92 \mathrm{E}+0$ \\
\hline 11 & 4.5 & 4.91 & 0.2 & high & & $6.04 \mathrm{E}+01$ & $1.60 \mathrm{E}+02$ & $1.56 \mathrm{E}+04$ & $2.16 \mathrm{E}+04$ & $5.43 E \div 05$ & $>3.68 \mathrm{E}$ & $1.73 \mathrm{E}+03$ & $1.01 E+04$ \\
\hline 31 & 4.5 & 4.91 & 0.2 & high & & $6.04 \mathrm{E}+01$ & $1.60 \mathrm{E}+02$ & $1.56 \mathrm{E}+04$ & $2.16 \mathrm{E}+04$ & $6.49 \mathrm{E}+05$ & $>3.68 \mathrm{E}+05$ & $1.91 E+03$ & $1.02 \mathrm{E}+04$ \\
\hline 15 & 7.5 & 8.20 & 0.2 & low & & $8.28 \mathrm{E}+00$ & $1.12 \mathrm{E}+00$ & $2.30 E+03$ & $5.90 \mathrm{E}+02$ & $2.49 \mathrm{E}+04$ & $1.01 \mathrm{E}+04$ & $4.06 \mathrm{E}+03$ & $1.11 \mathrm{E}+04$ \\
\hline 18 & 7.5 & 8.20 & 0.2 & low & & $8.28 \mathrm{E}+00$ & $1.44 \mathrm{E}+00$ & $2.30 \mathrm{E}+03$ & $5.90 \mathrm{E}+02$ & $2.69 E+04$ & $8.42 \mathrm{E}+03$ & $3.43 E+03$ & 1.37E+04 \\
\hline 1 & 7.5 & 8.20 & 0.2 & high & & $1.00 \mathrm{E}+02$ & $2.67 \mathrm{E}+02$ & $2.60 \mathrm{E}+04$ & $3.58 \mathrm{E}+04$ & $2.14 \mathrm{E}+05$ & $>6.15 \mathrm{E}+05$ & $3.32 \mathrm{E}+03$ & 1.09E+04 \\
\hline 28 & 7.5 & 8.20 & 0.2 & high & & $1.00 \mathrm{E}+02$ & $2.67 \mathrm{E}+02$ & $2.60 E+04$ & $3.58 \mathrm{E}+04$ & $2.30 \mathrm{E}+05$ & $>6.15 \mathrm{E}+05$ & $2.56 \mathrm{E}+03$ & $9.02 E+03$ \\
\hline 4 & 4.5 & 4.91 & 2.0 & low & & $4.98 \mathrm{E}+00$ & $5.60 \mathrm{E}-01$ & $1.38 E+03$ & $3.54 \mathrm{E}+02$ & $2.75 E+05$ & $1.13 E+03$ & $>3.4$ & $>4.92 \mathrm{E}+\mathrm{C}$ \\
\hline 30 & 4.5 & 4.91 & 2.0 & low & & $4.98 \mathrm{E}+00$ & $5.60 \mathrm{E}-01$ & $1.38 \mathrm{E}+03$ & $3.54 \mathrm{E}+02$ & $2.50 \mathrm{E}+05$ & $9.60 \mathrm{E}+02$ & $>3.46 \mathrm{E}+05$ & $>4.92 \mathrm{E}+$ \\
\hline 20 & 4.5 & 4.91 & 2.0 & high & & $6.04 \mathrm{E}+01$ & $1.60 \mathrm{E}+02$ & $1.56 \mathrm{E}+04$ & $2.16 E+04$ & $5.39 \mathrm{E}$ & & & $3.68 E+04$ \\
\hline 29 & 4.5 & 4.91 & 2.0 & high & & $6.04 \mathrm{E}+01$ & $1.60 \mathrm{E}+02$ & $1.56 \mathrm{E}+04$ & $2.16 \mathrm{E}+04$ & $5.56 \mathrm{E}+05$ & $>3.68 \mathrm{E}+04$ & $5.05 E+03$ & 4.57E +04 \\
\hline 8 & 7.5 & 8.20 & 2.0 & low & & $8.28 \mathrm{E}+00$ & $5.60 \mathrm{E}-01$ & $2.30 \mathrm{E}+03$ & $5.90 \mathrm{E}+02$ & $2.99 E+04$ & $8.30 \mathrm{E}+02$ & & $>8.24 \mathrm{E}+0$ \\
\hline 23 & 7.5 & 8.20 & 2.0 & low & & 8.28E+00 & $5.60 \mathrm{E}-01$ & $2.30 \mathrm{E}+03$ & $5.90 \mathrm{E}+02$ & $2.29 \mathrm{E}+04$ & $1.44 \mathrm{E} \div 03$ & $9.00 E+03$ & $>8.24 \mathrm{E}+$ \\
\hline 17 & 7.5 & 8.20 & 2.0 & high & & & $2.67 \mathrm{E}+02$ & $2.60 E+04$ & & & & & $8.82 E+03$ \\
\hline 27 & 7.5 & 8.20 & 2.0 & high & & $1.00 \mathrm{E}+02$ & $2.67 \mathrm{E}+02$ & $2.60 E+04$ & $3.58 E+04$ & $5.09 \mathrm{E}+05$ & $>6.15 E+04$ & $1.74 E+03$ & $8.31 E+03$ \\
\hline
\end{tabular}

Special Note: $a=$ unmixed $\mathrm{b}=400 \mathrm{mg} / \mathrm{L}$ NaTPB $c=400 \mathrm{mg} / \mathrm{L}$ sludge 


\section{Appendix 9 \\ Calculation of Np-237 Concentration in SRS High-Level Waste}

$\begin{array}{ll}\text { Author: } & \text { John Fowler at SRCCHO2 } \\ \text { Date: } & 4 / 26 / 99 \text { 5:55 PM } \\ \text { Priority: } & \text { Normal } \\ \text { To: } & \text { David Hobbs at SRCCA03 } \\ \text { Subject: } & \text { Re: Np Reference }\end{array}$

I think all I had was an e-mail, which I didn't archive. Paul Rutland may have a copy. In any case, here's a calculation based on data in Table D1(a) and D1(c) in Appendix D of the "Bases, Assumptions, and Results of the Flowsheet Calculations for the Short List Salt Disposition Alternatives," WSRC-RP-98-00168, Revision 1, [Scott Beck et al.].

D1(a) shows Tanks 33 and 34 have the most Np-237 inventory from the WCS data base. All other tanks are at least a factor of 10 lower in total $\mathrm{Ci}$ of $\mathrm{Np}$.

Tank 33 contains 191,700 gallons of free supernate with a sp. g. of 1.18 . This solution has $0.613 \mathrm{Ci}$ of Np-237 dissolved in it, and would generate 90,600 gallons of $6.45 \mathrm{M} \mathrm{Na}+$ to feed one of the processes. The Specific Activity for Np-237 = 7.05E-4 Ci/g.

$$
\begin{aligned}
& 0.613 \mathrm{Ci} /(3.7854 \mathrm{~L} / \mathrm{gal} \times 90,600 \mathrm{gal})=1.8 \mathrm{E}-6 \mathrm{Ci} / \mathrm{L} @ 6.45 \mathrm{M} \mathrm{Na}+ \\
& (1.8 \mathrm{E}-6 \mathrm{Ci} / \mathrm{L}) /(7.05 \mathrm{E}-4 \mathrm{Ci} / \mathrm{g})=2.5 \mathrm{E}-3 \mathrm{~g} / \mathrm{L} \text { or } 2.5 \mathrm{mg} / \mathrm{L}
\end{aligned}
$$

Tank 33 solution still has to be evaporated, so it likely isn't representative of what would be really be present in $6.45 \mathrm{M}$ feed.

Tank 34 contains 920,900 gallons of free supernate with a sp g of 1.38 that would yield 1.488E6 gallons of $6.45 \mathrm{M}$ feed solution. This supernate has $1.79 \mathrm{Ci}$ of $\mathrm{Np}-237$. The sp $\mathrm{g}$ shows it has been at partially processed through the evaporator, and would be diluted slightly to be at $6.45 \mathrm{M} \mathrm{Na}+$. Here's the calc for this solution:

$1.79 \mathrm{Ci} /(3.7854 \mathrm{~L} / \mathrm{gal} \times 1,488,000 \mathrm{gal})=3.2 \mathrm{E}-7 \mathrm{Ci} / \mathrm{L}$

$$
(3.2 \mathrm{E}-7 \mathrm{Ci} / \mathrm{L}) /(7.05 \mathrm{E}-4 \mathrm{Ci} / \mathrm{g})=4.5 \mathrm{E}-4 \mathrm{~g} / \mathrm{L} \text { or } 0.45 \mathrm{mg} / \mathrm{L} @ 6.45 \mathrm{M} \mathrm{Na}+
$$

Bounding concentration in existing waste is thus $2.5 \mathrm{mg} / \mathrm{L} @ 6.45 \mathrm{M} \mathrm{Na}$ in Tank 33, although $<0.5$ $\mathrm{mg} / \mathrm{L}$ is more representative of stuff that's been evaporated. The $\mathrm{Np}-237$ inventory in free supernate in all other tanks are at least a factor of 10 below Tank 34. 


\section{Appendix 10.}

\section{Concentration versus Time Data for Tests at} 4.5 $\mathrm{M} \mathrm{Na}^{+}, 0.2 \mathrm{~g} / \mathrm{L}$ MST, Low Activity Solution

\section{(Bottles \# 22 and 25)}

(Units of Time $=$ hours; Units of Concentration $=\mu \mathrm{g} / \mathrm{L}$ )

\begin{tabular}{|c|c|c|c|c|}
\hline $22 \mathrm{Ti}$ & $222 \mathrm{Sr}$ & $222 \mathrm{Pu}$ & $222 \mathrm{~Np}$ & $222 \mathrm{U}$ \\
\hline 0 & $4.96 \mathrm{E}+00$ & $1.12 \mathrm{E}+00$ & $3.40 \mathrm{E}+02$ & $1.52 E+03$ \\
\hline 2.40 & 8.67E-01 & $1.99 \mathrm{E}-01$ & $1.33 E+02$ & $1.34 E+03$ \\
\hline 4.33 & & & $4.08 \mathrm{E}+01$ & $1.02 E+03$ \\
\hline & & $92 \mathrm{E}-02$ & 4.37E+01 & $9.72 E+02$ \\
\hline 24.28 & & $4.85 \mathrm{E}-02$ & & \\
\hline 48.28 & $1,59 \mathrm{E}-01$ & $1.50 \mathrm{E}-01$ & & \\
\hline 168.13 & I.75E-01 & $1.62 \mathrm{E}-01$ & $2.48 \mathrm{E}+01$ & $6.70 E+02$ \\
\hline 9.95 & & & $1.88 \mathrm{E}+01$ & $5.98 \mathrm{E}+02$ \\
\hline $37 \mathrm{~lm}$ & & & & $225 \mathrm{U}$ \\
\hline 0 & $4.96 \mathrm{E}+00$ & 1.12 & $3.40 \mathrm{E}+02$ & $1.52 E+03$ \\
\hline 2.43 & $9.08 \mathrm{E}-01$ & & $1.03 E+02$ & $1.28 \mathrm{E}+03$ \\
\hline 4.40 & $3.48 \mathrm{I}$ & 5.44 & $6.41 \mathrm{E}+01$ & $1.14 \mathrm{E}+03$ \\
\hline 8,38 & $2.60 \mathrm{E}$ & & $6.97 \mathrm{E}+0 \mathrm{I}$ & $9.94 \mathrm{E}+02$ \\
\hline 24,32 & $1.98 \mathrm{E}$ & 1.10 & 2.0 & $7.52 \mathrm{E}+02$ \\
\hline 48.33 & 1.61 & & & \\
\hline 168.17 & 01 & & $2.58 \mathrm{E}$ & $6.90 \mathrm{E}+02$ \\
\hline 9.98 & $1.53 \mathrm{E}$ & & $2.37 \mathrm{E}+01$ & $6.26 \mathrm{E}+02$ \\
\hline \multicolumn{5}{|c|}{ verages of Duplicate Tests - Bottle $\# 22$ and $\# 25$} \\
\hline Time & $25 \mathrm{Sr}$ & $25 \mathrm{Pu}$ & $25 \mathrm{~Np}$ & \\
\hline o & & & & $1.52 \mathrm{E}+03$ \\
\hline & 8.87E-01 & & $\mathrm{I} .18 \mathrm{E}+02$ & $1.31 \mathrm{E}+03$ \\
\hline & $3.68 \mathrm{E}-01$ & 1.56 & $5.25 \mathrm{E}-$ & $1.08 \mathrm{E}+03$ \\
\hline 8.355 & $2.63 \mathrm{E}$ & 1.92 & $5.67 \mathrm{E}$ & $9.83 E+02$ \\
\hline 24.3 & 1.931 & 7.93 & $2,00 \mathrm{E}$ & 7.38 \\
\hline 48. & 1.60 & & & \\
\hline & & $1.69 \mathrm{E}$ & & \\
\hline 239.965 & 0.020 & $1.36 \mathrm{E}-0$ & & \\
\hline
\end{tabular}

422 Time $422 \mathrm{Sr} \quad 422 \mathrm{Pu} \quad 422 \mathrm{~Np} \quad 422 \mathrm{U}$ $\begin{array}{lllll}0 & 4.98 \mathrm{E}+00 & 1.74 \mathrm{E}+00 & 5.88 \mathrm{E}+02 & \mathrm{I} .56 \mathrm{E}+03\end{array}$ $2.53 \quad 1.38 \mathrm{E}-01 \quad 5.38 \mathrm{E}-02 \quad 4.40 \mathrm{E}+01 \quad 9.77 \mathrm{E}+02$ $4.53 \quad$ 1.13E-01 9.89E-02 2.14E+00 8.43E+02 $\begin{array}{llllll}8.53 & 9.05 \mathrm{E}-02 & 9.03 \mathrm{E}-02 & 3.24 \mathrm{E}+01 & 8.61 \mathrm{E}+02\end{array}$ $24.65 \quad 8.94 \mathrm{E}-02 \quad 7.21 \mathrm{E}-02 \quad 4.23 \mathrm{E}+01 \quad 8.1 \mathrm{IE}+02$ 48.50 1.07E-01 $\quad$ L.42E-01 3.65E+01 $1.10 E+03$ $95.98 \quad 1.38 \mathrm{E}-01 \quad$ I.40E-01 $2.26 \mathrm{E}+01 \quad 5.94 \mathrm{E}+02$ $\begin{array}{llllll}168.27 \quad 2.88 \mathrm{E}-01 & 6.34 \mathrm{E}-02 & 2.62 \mathrm{E}+01 \quad 6.07 \mathrm{E}+02\end{array}$

425 Time $\quad 425 \mathrm{Sr} \quad 425 \mathrm{Pu} \quad 425 \mathrm{~Np} \quad 425 \mathrm{U}$ $\begin{array}{lllll}0 & 4.98 \mathrm{E}+00 & 1.74 \mathrm{E}+00 & 5.88 \mathrm{E}+02 & 1.56 \mathrm{E}+03\end{array}$ $2.60 \quad 1.44 \mathrm{E}-01 \quad 8.96 \mathrm{E}-02 \quad 3.38 \mathrm{E}+01 \quad 1.01 \mathrm{E}+03$

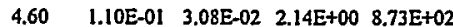
$\begin{array}{lllll}8.60 & 9.40 \mathrm{E}-02 & 4.65 \mathrm{E}-02 & 3.63 \mathrm{E}+01 & 8.68 \mathrm{E}+02\end{array}$ $24.73 \quad 9.63 \mathrm{E}-02 \quad 1.96 \mathrm{E}-01 \quad 2.82 \mathrm{E}+01 \quad 9.44 \mathrm{E}+02$ $\begin{array}{lllll}48.57 \quad 9.45 \mathrm{E}-02 & 5.47 \mathrm{E}-02 & 3.08 \mathrm{E}+00 & 5.82 \mathrm{E}+02\end{array}$ $\begin{array}{llllll}96.07 & 1.26 \mathrm{E}-01 & 2.37 \mathrm{E}-01 & 3.64 \mathrm{E}+00 & 5.80 \mathrm{E}+02\end{array}$ $168.32 \quad 2.41 \mathrm{E}-01 \quad 2.40 \mathrm{E}-01 \quad 4.24 \mathrm{E}+00 \quad 5.97 \mathrm{E}+02$

$45 \mathrm{Time} \quad 45 \mathrm{Sr} \quad 45 \mathrm{Pu} \quad 45 \mathrm{~Np} \quad 45 \mathrm{U}$ $\begin{array}{lllll}0 & 4.98 \mathrm{E}+00 & 1.74 \mathrm{E}+00 & 5.88 \mathrm{E}+02 & 1.56 \mathrm{E}+03\end{array}$ $2.565 \quad 1.41 \mathrm{E}-01 \quad 7.17 \mathrm{E}-02 \quad 3.89 \mathrm{E}+01 \quad 9.94 \mathrm{E}+02$ $4.565 \quad 1.12 \mathrm{E}-01 \quad 6.48 \mathrm{E}-02 \quad 2.14 \mathrm{E}+00 \quad 8.58 \mathrm{E}+02$ $\begin{array}{llllll}8.565 & 9.23 \mathrm{E}-02 & 6.84 \mathrm{E}-02 & 3.44 \mathrm{E}+01 & 8.65 \mathrm{E}+02\end{array}$ $24.69 \quad 9.28 \mathrm{E}-02 \quad 1.34 \mathrm{E}-01 \quad 3.53 \mathrm{E}+01 \quad 8.78 \mathrm{E}+02$ $\begin{array}{lllll}48.535 & 1.01 \mathrm{E}-01 & 9.81 \mathrm{E}-02 & 1.98 \mathrm{E}+01 & 8.43 \mathrm{E}+02\end{array}$ 96.025 1.32E-01 1.89E-01 $\quad$ I.31E $+01 \quad 5.87 \mathrm{E}+02$ $\begin{array}{lllll}168.295 & 2.64 E-01 & 1.52 E-01 & 1.52 E+01 & 6.02 E+02\end{array}$

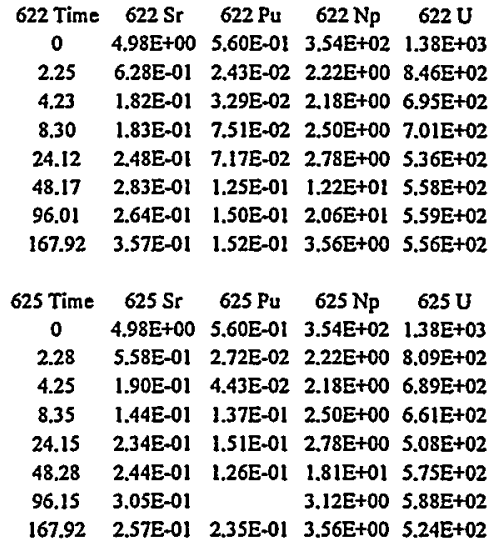




\section{Appendix 11.}

Concentration versus Time Data for Tests at

\section{5 $\mathrm{M} \mathrm{Na}^{+}, 2.0 \mathrm{~g} / \mathrm{L} \mathrm{MST}$, Low Activity Solution}

(Bottles \# 04 and 30)

(Units of Time $=$ hours; Units of Concentration $=\mu \mathrm{g} / \mathrm{L}$ )

\begin{abstract}
204 Time $204 \mathrm{Sr} \quad 204 \mathrm{Pu} \quad 204 \mathrm{~Np} \quad 204 \mathrm{U}$
$\begin{array}{lllll}0 & 4.96 \mathrm{E}+00 & 1.14 \mathrm{E}+00 & 3.40 \mathrm{E}+02 & 1.52 \mathrm{E}+03\end{array}$

$\begin{array}{lllll}2.18 & 1.76 \mathrm{E}-01 & 7.01 \mathrm{E}-02 & 2.00 \mathrm{E}+00 & 3.46 \mathrm{E}+02\end{array}$

$4.15 \quad 4.97 \mathrm{E}-02 \quad 4.92 \mathrm{E}-02 \quad 1.88 \mathrm{E}+01 \quad 1.14 \mathrm{E}+02$

$8.13 \quad 3.75 \mathrm{E}-02 \quad 1.92 \mathrm{E}-02 \quad 2.00 \mathrm{E}+00 \quad 9.88 \mathrm{E}+01$

$\begin{array}{lllll}24.12 & 4.24 \mathrm{E}-02 & 8.32 \mathrm{E}-01 & 2.00 \mathrm{E}+00 & 2.00 \mathrm{E}+00\end{array}$

$\begin{array}{llllll}48.13 & 3.96 \mathrm{E}-02 & 9.46 \mathrm{E}-03 & 2.00 \mathrm{E}+00 & 2.00 \mathrm{E}+00\end{array}$

$\begin{array}{llllll}167.98 & 7.23 \mathrm{E}-03 & 4.62 \mathrm{E}-02 & 2.00 \mathrm{E}+00 & 2.00 \mathrm{E}+00\end{array}$

$239.75 \quad 1.74 \mathrm{E}-03 \quad 9.40 \mathrm{E}-02 \quad 2.00 \mathrm{E}+00 \quad 2.00 \mathrm{E}+00$

$230 \mathrm{Time} 230 \mathrm{Sr} \quad 230 \mathrm{Pu} \quad 230 \mathrm{~Np} \quad 230 \mathrm{U}$

$\begin{array}{lllll}0 & 4.96 \mathrm{E}+00 & 1.14 \mathrm{E}+00 & 3.40 \mathrm{E}+02 & 1.52 \mathrm{E}+03\end{array}$

$\begin{array}{llllll}2.45 & 2.30 \mathrm{E}-01 & 5.14 \mathrm{E}-02 & 5.76 \mathrm{E}+01 & 3.86 \mathrm{E}+02\end{array}$

$\begin{array}{lllll}4.42 & 3.97 \mathrm{E}-02 & 7.86 \mathrm{E}-02 & 1.29 \mathrm{E}+01 & 1.23 \mathrm{E}+02\end{array}$

$8.57 \quad 5.38 \mathrm{E}-02 \quad 3.75 \mathrm{E}-02 \quad 2.00 \mathrm{E}+00 \quad 1.03 \mathrm{E}+02$

$\begin{array}{llllll}24.33 & 3.95 \mathrm{E}-02 & 1.25 \mathrm{E}-01 & 2.00 \mathrm{E}+00 & 2.00 \mathrm{E}+00\end{array}$

$48.35 \quad 3.19 \mathrm{E}-02 \quad 1.10 \mathrm{E}-01 \quad 0.00 \mathrm{E}+00 \quad 2.00 \mathrm{E}+00$

$168.10 \quad 1.50 \mathrm{E}-03 \quad 1.17 \mathrm{E}-01 \quad 2.00 \mathrm{E}+00 \quad 2.00 \mathrm{E}+00$

$239.98 \quad 2.45 \mathrm{E}-02 \quad 1.80 \mathrm{E}-01 \quad 2.00 \mathrm{E}+00 \quad 1.16 \mathrm{E}+01$

Averages of Duplicate Tests - Bottle \#4 and \#30

Time $25 \mathrm{Sr} 25 \mathrm{Pu} 25 \mathrm{~Np} 25 \mathrm{U}$

$\begin{array}{ccccc}0 & 4.96 \mathrm{E}+00 & 1.14 \mathrm{E}+00 & 3.40 \mathrm{E}+02 & 1.52 \mathrm{E}+03\end{array}$

$2.315 \quad 2.03 \mathrm{E}-01 \quad 6.08 \mathrm{E}-02 \quad 2.98 \mathrm{E}+01 \quad 3.66 \mathrm{E}+02$

4.285 4.47E-02 6.39E-02 $1.59 \mathrm{E}+01 \quad 1.19 \mathrm{E}+02$

$\begin{array}{lllll}8.35 & 4.57 \mathrm{E}-02 & 2.84 \mathrm{E}-02 & 2.00 \mathrm{E}+00 & 1.01 \mathrm{E}+02\end{array}$

$24.225 \quad 4.10 \mathrm{E}-02 \quad 4.79 \mathrm{E}-01 \quad 2.00 \mathrm{E}+00 \quad 2.00 \mathrm{E}+00$

$48.24 \quad 3.57 \mathrm{E}-02 \quad 5.98 \mathrm{E}-02 \quad 1.00 \mathrm{E}+00 \quad 2.00 \mathrm{E}+00$

$\begin{array}{llllll}168.04 & 4.37 \mathrm{E}-03 & 8.14 \mathrm{E}-02 & 2.00 \mathrm{E}+00 & 2.00 \mathrm{E}+00\end{array}$

$239.865 \quad 1.31 \mathrm{E}-02 \quad 1.37 \mathrm{E}-01 \quad 2.00 \mathrm{E}+00 \quad 6.81 \mathrm{E}+00$
\end{abstract}

$\begin{array}{ccccc}404 \mathrm{Time} & 404 \mathrm{Sr} & 404 \mathrm{Pu} & 404 \mathrm{~Np} & 404 \mathrm{U} \\ 0 & 4.98 \mathrm{E}+00 & 1.74 \mathrm{E}+00 & 5.88 \mathrm{E}+02 & 1.56 \mathrm{E}+03 \\ 2.07 & 1.35 \mathrm{E}-02 & 2.93 \mathrm{E}-02 & 1.35 \mathrm{E}+01 & 1.27 \mathrm{E}+02 \\ 4.07 & 5.46 \mathrm{E}-03 & 2.22 \mathrm{E}-02 & 2.14 \mathrm{E}+00 & 2.00 \mathrm{E}+00 \\ 8.07 & 1.16 \mathrm{E}-02 & 3.04 \mathrm{E}-02 & 2.66 \mathrm{E}+00 & 4.60 \mathrm{E}+01 \\ 24.20 & 1.27 \mathrm{E}-02 & 4.21 \mathrm{E}-01 & 2.82 \mathrm{E}+00 & 2.00 \mathrm{E}+00 \\ 48.08 & 8.87 \mathrm{E}-03 & 2.85 \mathrm{E}-01 & 3.08 \mathrm{E}+00 & 2.00 \mathrm{E}+00 \\ 95.53 & 0.00 \mathrm{E}+00 & 4.54 \mathrm{E}-01 & 3.64 \mathrm{E}+00 & 1.68 \mathrm{E}+01 \\ 167.90 & 3.60 \mathrm{E}-02 & 2.18 \mathrm{E}-01 & 4.24 \mathrm{E}+00 & 1.13 \mathrm{E}+01\end{array}$

$430 \mathrm{Time} \quad 430 \mathrm{Sr} \quad 430 \mathrm{Pu} \quad 430 \mathrm{~Np} \quad 430 \mathrm{U}$

$\begin{array}{lllll}0 & 4.98 \mathrm{E}+00 & 1.74 \mathrm{E}+00 & 5.88 \mathrm{E}+02 & 1.56 \mathrm{E}+03\end{array}$

$\begin{array}{llllll}2.73 & 1.54 \mathrm{E}-02 & 9.06 \mathrm{E}-02 & 2.22 \mathrm{E}+00 & 2.86 \mathrm{E}+02\end{array}$

$4.73 \quad 1.68 \mathrm{E}-02 \quad 7.25 \mathrm{E}-03 \quad 2.14 \mathrm{E}+00 \quad 2.00 \mathrm{E}+00$

8.70 8.15E-03 4.17E-02 2.66E+00 5.00E+01

$\begin{array}{llllll}24.83 & 1.66 \mathrm{E}-02 & 9.78 \mathrm{E}-02 & 2.82 \mathrm{E}+00 & 2.00 \mathrm{E}+00\end{array}$

$\begin{array}{llllll}48.67 & 7.82 \mathrm{E}-03 & 1.44 \mathrm{E}-01 & 3.08 \mathrm{E}+00 & 2.00 \mathrm{E}+00\end{array}$

$96.17 \quad 1.58 \mathrm{E}-02 \quad 3.28 \mathrm{E}-01 \quad 3.64 \mathrm{E}+00 \quad 1.47 \mathrm{E}+01$

$\begin{array}{llllllll}168.43 \quad 1.48 \mathrm{E}-02 & 1.58 \mathrm{E}-01 & 4.24 \mathrm{E}+00 & 2.00 \mathrm{E}+00\end{array}$

45 Time $45 \mathrm{Sr} \quad 45 \mathrm{Pu} \quad 45 \mathrm{~Np} \quad 45 \mathrm{U}$

$\begin{array}{lllll}0 & 4.98 \mathrm{E}+00 & 1.74 \mathrm{E}+00 & 5.88 \mathrm{E}+02 & 1.56 \mathrm{E}+03\end{array}$

$2.4 \quad 1.44 \mathrm{E}-02 \quad 6.00 \mathrm{E}-02 \quad 7.86 \mathrm{E}+00 \quad 2.06 \mathrm{E}+02$

$4.4 \quad 1.11 \mathrm{E}-02 \quad 1.47 \mathrm{E}-02 \quad 2.14 \mathrm{E}+00 \quad 2.00 \mathrm{E}+00$

$\begin{array}{llllll}8.385 & 9.89 \mathrm{E}-03 & 3.61 \mathrm{E}-02 & 2.66 \mathrm{E}+00 & 4.80 \mathrm{E}+0 \mathrm{l}\end{array}$

$24.515 \quad 1.47 \mathrm{E}-02 \quad 2.59 \mathrm{E}-01 \quad 2.82 \mathrm{E}+00 \quad 2.00 \mathrm{E}+00$

48.375 8.34E-03 2.14E-01 3.08E+00 2.00E+00

$\begin{array}{llllll}95.85 & 7.88 \mathrm{E}-03 & 3.91 \mathrm{E}-01 & 3.64 \mathrm{E}+00 & 1.58 \mathrm{E}+01\end{array}$

$\begin{array}{lllll}168.165 & 2.54 \mathrm{E}-02 & 1.88 \mathrm{E}-01 & 4.24 \mathrm{E}+00 & 6.64 \mathrm{E}+00\end{array}$ $\begin{array}{ccccc}604 \text { Time } & 604 \mathrm{Sr} & 604 \mathrm{Pu} & 604 \mathrm{~Np} & 604 \mathrm{U} \\ 0 & 4.98 \mathrm{E}+00 & 5.60 \mathrm{E}-01 & 3.54 \mathrm{E}+02 & 1.38 \mathrm{E}+03 \\ 2.03 & 1.21 \mathrm{E}-01 & & 2.22 \mathrm{E}+00 & 8.35 \mathrm{E}+01 \\ 4.03 & 1.63 \mathrm{E}-02 & 7.73 \mathrm{E}-02 & 2.18 \mathrm{E}+00 & 3.60 \mathrm{E}+01 \\ 8.08 & 2.48 \mathrm{E}-02 & 7.25 \mathrm{E}-02 & 2.50 \mathrm{E}+00 & 2.75 \mathrm{E}+01 \\ 23.95 & 1.16 \mathrm{E}-02 & 1.44 \mathrm{E}-01 & 2.78 \mathrm{E}+00 & 2.00 \mathrm{E}+00 \\ 47.97 & 1.65 \mathrm{E}-02 & 1.69 \mathrm{E}-01 & 3.12 \mathrm{E}+00 & 1.70 \mathrm{E}+01 \\ 95.93 & 9.04 \mathrm{E}-03 & 1.75 \mathrm{E}-01 & 3.12 \mathrm{E}+00 & 2.00 \mathrm{E}+00 \\ 167.65 & 4.97 \mathrm{E}-04 & 1.72 \mathrm{E}-01 & 3.56 \mathrm{E}+00 & 2.00 \mathrm{E}+00 \\ & & & & \\ 630 \mathrm{Time} & 630 \mathrm{Sr} & 630 \mathrm{Pu} & 630 \mathrm{~Np} & 630 \mathrm{U} \\ 0 & 4.98 \mathrm{E}+00 & 5.60 \mathrm{E}-01 & 3.54 \mathrm{E}+02 & 1.38 \mathrm{E}+03 \\ 2.30 & 1.15 \mathrm{E}-01 & 7.83 \mathrm{E}-02 & 2.22 \mathrm{E}+00 & 7.97 \mathrm{E}+01 \\ 4.27 & 7.10 \mathrm{E}-03 & 1.94 \mathrm{E}-02 & 2.18 \mathrm{E}+00 & 2.00 \mathrm{E}+00 \\ 7.37 & 1.95 \mathrm{E}-02 & 6.17 \mathrm{E}-02 & 2.50 \mathrm{E}+00 & 2.00 \mathrm{E}+00 \\ 24.17 & 1.07 \mathrm{E}-02 & 2.14 \mathrm{E}-01 & 2.78 \mathrm{E}+00 & 2.00 \mathrm{E}+00 \\ 48.28 & 9.92 \mathrm{E}-03 & 1.08 \mathrm{E}-01 & 1.11 \mathrm{E}+01 & 1.18 \mathrm{E}+02 \\ 96.15 & 3.48 \mathrm{E}-03 & 1.14 \mathrm{E}-01 & 3.12 \mathrm{E}+00 & 5.22 \mathrm{E}+01 \\ 167.93 & 0.00 \mathrm{E}+00 & 1.92 \mathrm{E}-01 & 3.56 \mathrm{E}+00 & 2.00 \mathrm{E}+00\end{array}$

65 Time $\quad 65 \mathrm{Sr} \quad 65 \mathrm{Pu} \quad 65 \mathrm{~Np} \quad 65 \mathrm{U}$

$\begin{array}{lllllll}0 & 4.98 & 0.560268 & 3.54 \mathrm{E}+02 & 1.38 \mathrm{E}+03\end{array}$

$\begin{array}{llllll}2.165 & 0.11802 & 0.078333 & 2.22 \mathrm{E}+00 & 8.16 \mathrm{E}+01\end{array}$

$\begin{array}{llllll}4.15 & 0.01168 & 0.048306 & 2.18 \mathrm{E}+00 & 1.90 \mathrm{E}+01\end{array}$

$\begin{array}{lllllll}7.725 & 0.022126 & 0.067114 & 2.50 \mathrm{E}+00 & 1.47 \mathrm{E}+01\end{array}$

$\begin{array}{llllll}24.06 & 0.011183 & 0.179033 & 2.78 E+00 & 2.00 E+00\end{array}$

$\begin{array}{lllllll}48.125 & 0.01321 & 0.138331 & 7.10 \mathrm{E}+00 & 6.74 \mathrm{E}+01\end{array}$

$\begin{array}{llllll}96.04 & 0.006262 & 0.144308 & 3.12 \mathrm{E}+00 & 2.71 \mathrm{E}+01\end{array}$

$\begin{array}{llllll}167.79 & 0.000248 & 0.18188 & 3.56 \mathrm{E}+00 & 2.00 \mathrm{E}+00\end{array}$ 
Appendix 12.

Concentration versus Time Data for Tests at

6.0 $\mathrm{M} \mathrm{Na}^{+}, 1.1 \mathrm{~g} / \mathrm{L}$ MST, Low Activity Solution

(Bottles \# 10 and 24)

(Units of Time $=$ hours; Units of Concentration $=\mu \mathrm{g} / \mathrm{L}$ )

\begin{tabular}{|c|c|c|c|c|}
\hline $\begin{array}{c}10 \text { Time } \\
0\end{array}$ & $\begin{array}{c}210 \mathrm{Sr} \\
6.62 \mathrm{E}+00\end{array}$ & $\begin{array}{c}210 \mathrm{Pu} \\
6.66 \mathrm{E}+00\end{array}$ & $\begin{array}{c}210 \mathrm{~Np} \\
1.08 \mathrm{E}+03\end{array}$ & $\begin{array}{c}210 \mathrm{U} \\
2.04 \mathrm{E}+03\end{array}$ \\
\hline 2.28 & $3.86 \mathrm{E}-01$ & $1.6 \mathrm{tE}+00$ & $2.37 \mathrm{E}+02$ & $1.09 E+03$ \\
\hline 4.23 & $1.23 \mathrm{E}-01$ & $1.05 E+00$ & $1.01 E+02$ & $5.63 \mathrm{E}+02$ \\
\hline 8.20 & $8.95 \mathrm{E}-02$ & $9.21 \mathrm{E}-01$ & $7.00 E+01$ & $6.29 \mathrm{E}+02$ \\
\hline 24.17 & $5.52 \mathrm{E}-02$ & $3.01 E-01$ & $2.00 \mathrm{E}+00$ & $3.11 E+02$ \\
\hline 48.18 & 5.04E-02 & $9.46 \mathrm{E}-03$ & $2.00 \mathrm{E}+00$ & $2.42 E+02$ \\
\hline 168.05 & $4,06 \mathrm{E}-02$ & $2.91 \mathrm{E}-01$ & $8+\infty$ & $8.23 E+0]$ \\
\hline 23 & 3.81 & 01 & & $7.97 \mathrm{E}+01$ \\
\hline $224 \mathrm{Tim}$ & & & & \\
\hline 0 & $6.62 \mathrm{E}+00$ & $6.66 \mathrm{E}+00$ & $1.08 E+03$ & $2.04 E+03$ \\
\hline 2.42 & 3.19 & & $3.10 \mathrm{E}+02$ & $1.11 \mathrm{E}+03$ \\
\hline 4.3 & ! & & +02 & 7.64 \\
\hline & & & 8.6 & 5.31 \\
\hline & & & 2.0 & 2.84 \\
\hline & & & 2.00 & 2.00. \\
\hline & & & 2.57 & 9.92 \\
\hline 239.97 & & & $1.99 \mathrm{E}+01$ & 8.72E+01 \\
\hline \multicolumn{5}{|c|}{ Duplicate Tests - Bottle $\# 10$ and $\# 24$} \\
\hline Time & $25 \mathrm{Sr}$ & $25 \mathrm{Pu}$ & $25 \mathrm{~Np}$ & \\
\hline & & & & \\
\hline 2.35 & 3.52 & & 2.73 & $1.10 \mathrm{E}+03$ \\
\hline & 1 & & & $6.64 E+02$ \\
\hline & & & $7.82 \mathrm{E}+$ & $5.80 \mathrm{E}+02$ \\
\hline & & & & $2.98 E+02$ \\
\hline & & & $2.00 E \div 00$ & $1.22 \mathrm{E}+02$ \\
\hline & & & & $9.08 E+01$ \\
\hline 239.9] & $3.92 \mathrm{E} \cdot \mathrm{C}$ & $3.79 \mathrm{E}-01$ & $1.85 \mathrm{E}+01$ & 8.35E+01 \\
\hline
\end{tabular}

$\begin{array}{ccccc}410 \text { Time } & 410 \mathrm{Sr} & 410 \mathrm{Pu} & 410 \mathrm{~Np} & 410 \mathrm{U} \\ 0 & 6.62 \mathrm{E}+00 & 7.50 \mathrm{E}-01 & 7.82 \mathrm{E}+02 & 2.08 \mathrm{E}+03 \\ 2.25 & 1.26 \mathrm{E}-01 & 3.19 \mathrm{E}-01 & 3.07 \mathrm{E}+01 & 5.34 \mathrm{E}+02 \\ 4.25 & 1.20 \mathrm{E}-01 & 1.77 \mathrm{E}-01 & 2.14 \mathrm{E}+00 & 2.00 \mathrm{E}+00 \\ 8.23 & 7.76 \mathrm{E}-02 & 1.21 \mathrm{E}-01 & 2.66 \mathrm{E}+00 & 2.12 \mathrm{E}+02 \\ 24.37 & 5.36 \mathrm{E}-02 & 1.52 \mathrm{E}-01 & 2.82 \mathrm{E}+00 & 1.19 \mathrm{E}+02 \\ 48.23 & 7.36 \mathrm{E}-02 & 1.73 \mathrm{E}-01 & 3.08 \mathrm{E}+00 & 9.47 \mathrm{E}+01 \\ 95.72 & 6.40 \mathrm{E}-02 & 3.65 \mathrm{E}-01 & 3.64 \mathrm{E}+00 & 8.43 \mathrm{E}+01 \\ 168.03 & & 2.27 \mathrm{E}-01 & 4.24 \mathrm{E}+00 & 8.36 \mathrm{E}+01 \\ & & & & \\ 424 \mathrm{Time} & 424 \mathrm{Sr} & 424 \mathrm{Pu} & 424 \mathrm{~Np} & 424 \mathrm{U} \\ 0 & 6.62 \mathrm{E}+00 & 7.50 \mathrm{E}-01 & 7.82 \mathrm{E}+02 & 2.08 \mathrm{E}+03 \\ 2.57 & 1.25 \mathrm{E}-01 & 1.97 \mathrm{E}-01 & 4.89 \mathrm{E}+01 & 5.67 \mathrm{E}+02 \\ 4.58 & 1.24 \mathrm{E}-01 & 1.48 \mathrm{E}-01 & 2.14 \mathrm{E}+00 & 2.00 \mathrm{E}+00 \\ 8.57 & 8.61 \mathrm{E}-02 & 1.81 \mathrm{E}-01 & 2.66 \mathrm{E}+00 & 2.57 \mathrm{E}+02 \\ 24.70 & 4.71 \mathrm{E}-02 & 1.95 \mathrm{E}-01 & 2.82 \mathrm{E}+00 & 1.38 \mathrm{E}+02 \\ 48.55 & 4.86 \mathrm{E}-02 & 1.19 \mathrm{E}-01 & 3.08 \mathrm{E}+00 & 8.20 \mathrm{E}+01 \\ 96.05 & 5.84 \mathrm{E}-02 & 5.06 \mathrm{E}-01 & 3.64 \mathrm{E}+00 & 8.45 \mathrm{E}+01 \\ 168.30 & 1.22 \mathrm{E}-01 & 2.38 \mathrm{E}-01 & 4.24 \mathrm{E}+00 & 9.79 \mathrm{E}+01 \\ & & & & \\ & & & & \\ 45 \mathrm{Tim}= & 45 \mathrm{Sr} & 45 \mathrm{Pu} & 45 \mathrm{~Np} & 45 \mathrm{U} \\ 0 & 6.62 \mathrm{E}+00 & 7.50 \mathrm{E}-01 & 7.82 \mathrm{E}+02 & 2.08 \mathrm{E}+03 \\ 2.41 & 1.26 \mathrm{E}-01 & 2.58 \mathrm{E}-01 & 3.98 \mathrm{E}+01 & 5.51 \mathrm{E}+02 \\ 4.415 & 1.22 \mathrm{E}-01 & 1.63 \mathrm{E}-01 & 2.14 \mathrm{E}+00 & 2.00 \mathrm{E}+00 \\ 8.4 & 8.19 \mathrm{E}-02 & 1.51 \mathrm{E}-01 & 2.66 \mathrm{E}+00 & 2.34 \mathrm{E}+02 \\ 24.535 & 5.04 \mathrm{E}-02 & 1.74 \mathrm{E}-01 & 2.82 \mathrm{E}+00 & 1.29 \mathrm{E}+02 \\ 48.39 & 6.11 \mathrm{E}-02 & 1.46 \mathrm{E}-01 & 3.08 \mathrm{E}+00 & 8.83 \mathrm{E}+01 \\ 95.885 & 6.12 \mathrm{E}-02 & 4.36 \mathrm{E}-01 & 3.64 \mathrm{E}+00 & 8.44 \mathrm{E}+01 \\ 168.165 & 1.22 \mathrm{E}-01 & 2.32 \mathrm{E}-01 & 4.24 \mathrm{E}+00 & 9.08 \mathrm{E}+01 \\ & & & & \\ & & & & \end{array}$

$\begin{array}{ccccc}610 \text { Time } & 610 \mathrm{Sr} & 610 \mathrm{Pu} & 610 \mathrm{~Np} & 610 \mathrm{U} \\ 0 & 6.62 \mathrm{E}+00 & 7.50 \mathrm{E}-01 & 4.72 \mathrm{E}+02 & 1.84 \mathrm{E}+03 \\ 2.15 & 2.98 \mathrm{E}-01 & 8.49 \mathrm{E}-02 & 2.22 \mathrm{E}+00 & 2.98 \mathrm{E}+02 \\ 4.12 & 1.42 \mathrm{E}-01 & 5.42 \mathrm{E}-03 & 2.18 \mathrm{E}+00 & 2.16 \mathrm{E}+02 \\ 8.18 & 9.69 \mathrm{E}-02 & 6.17 \mathrm{E}-02 & 2.50 \mathrm{E}+00 & 1.43 \mathrm{E}+02 \\ 24.03 & 1.11 \mathrm{E}-01 & 8.65 \mathrm{E}-02 & 2.78 \mathrm{E}+00 & 1.00 \mathrm{E}+02 \\ 48.03 & 8.77 \mathrm{E}-02 & 1.10 \mathrm{E}-01 & 8.95 \mathrm{E}+00 & 1.33 \mathrm{E}+02 \\ 95.98 & 1.39 \mathrm{E}-01 & 1.24 \mathrm{E}-01 & 3.12 \mathrm{E}+00 & 8.00 \mathrm{E}+01 \\ 167.83 & 1.15 \mathrm{E}-01 & 1.20 \mathrm{E}-01 & 3.56 \mathrm{E}+00 & 1.02 \mathrm{E}+02 \\ & & & & \\ 624 \mathrm{Time} & 624 \mathrm{Sr} & 624 \mathrm{Pu} & 624 \mathrm{~Np} & 624 \mathrm{U} \\ 0 & 6.62 \mathrm{E}+00 & 7.50 \mathrm{E}-01 & 4.72 \mathrm{E}+02 & 1.84 \mathrm{E}+03 \\ 2.27 & 3.26 \mathrm{E}-01 & 9.70 \mathrm{E}-02 & 2.22 \mathrm{E}+00 & 3.48 \mathrm{E}+02 \\ 4.23 & 1.36 \mathrm{E}-01 & 5.58 \mathrm{E}-02 & 2.18 \mathrm{E}+00 & 1.81 \mathrm{E}+02 \\ 8.33 & 7.49 \mathrm{E}-02 & 1.03 \mathrm{E}-01 & 2.50 \mathrm{E}+00 & 1.12 \mathrm{E}+02 \\ 24.13 & 1.01 \mathrm{E}-01 & 1.24 \mathrm{E}-01 & 2.78 \mathrm{E}+00 & 2.00 \mathrm{E}+00 \\ 48.23 & 9.19 \mathrm{E}-02 & 8.99 \mathrm{E}-02 & 3.12 \mathrm{E}+00 & 1.29 \mathrm{E}+02 \\ 96.13 & 1.05 \mathrm{E}-01 & 5.19 \mathrm{E}-02 & 3.12 \mathrm{E}+00 & 8.57 \mathrm{E}+01 \\ 167.92 & 1.09 \mathrm{E}-01 & 2.06 \mathrm{E}-01 & 3.56 \mathrm{E}+00 & 1.30 \mathrm{E}+02 \\ & & & & \\ & & & & \\ 65 \mathrm{Time} & 65 \mathrm{Sr} & 65 \mathrm{Pu} & 65 \mathrm{~Np} & 65 \mathrm{U} \\ 0 & 6.62 \mathrm{E}+00 & 7.50 \mathrm{E}-01 & 4.72 \mathrm{E}+02 & 1.84 \mathrm{E}+03 \\ 2.21 & 3.12 \mathrm{E}-01 & 9.10 \mathrm{E}-02 & 2.22 \mathrm{E}+00 & 3.23 \mathrm{E}+02 \\ 4.175 & 1.39 \mathrm{E}-01 & 3.06 \mathrm{E}-02 & 2.18 \mathrm{E}+00 & 1.98 \mathrm{E}+02 \\ 8.255 & 8.59 \mathrm{E}-02 & 8.21 \mathrm{E}-02 & 2.50 \mathrm{E}+00 & 1.28 \mathrm{E}+02 \\ 24.08 & 1.06 \mathrm{E}-01 & 1.05 \mathrm{E}-01 & 2.78 \mathrm{E}+00 & 5.10 \mathrm{E}+01 \\ 48.13 & 8.98 \mathrm{E}-02 & 1.00 \mathrm{E}-01 & 6.04 \mathrm{E}+00 & 1.31 \mathrm{E}+02 \\ 96.055 & 1.22 \mathrm{E}-01 & 8.80 \mathrm{E}-02 & 3.12 \mathrm{E}+00 & 8.28 \mathrm{E}+01 \\ 167.875 & 1.12 \mathrm{E}-01 & 1.63 \mathrm{E}-01 & 3.56 \mathrm{E}+00 & 1.16 \mathrm{E}+02\end{array}$




\section{Appendix 13. \\ Concentration versus Time Data for Tests at 6.0 $\mathrm{M} \mathrm{Na}^{+}, 1.1 \mathrm{~g} / \mathrm{L}$ MST, Low Activity Solution, No Mixing (Bottles \# 16 and 26) \\ (Units of Time $=$ hours; Units of Concentration $=\mu \mathrm{g} / \mathrm{L}$ )}

\begin{tabular}{|c|c|c|c|c|}
\hline 216 Time & & & $216 \mathrm{~Np}$ & \\
\hline 0 & $6.62 \mathrm{E}+\infty 0$ & $6.66 \mathrm{E}+00$ & $1.08 \mathrm{E}+03$ & $2.04 E+03$ \\
\hline 2.17 & $1.90 \mathrm{E}-01$ & $1.02 E+00$ & $1.58 E+02$ & $7.96 \mathrm{E}+02$ \\
\hline 4.40 & 1. $13 E-01$ & $3.80 \mathrm{E}-01$ & $6.33 \mathrm{E}+01$ & $5.66 \mathrm{E}+02$ \\
\hline 8.47 & $9.36 \mathrm{E}-02$ & 7.75E-01 & $6.02 E+0 !$ & $4.65 E+02$ \\
\hline 24.35 & 8.44E-02 & $6.71 \mathrm{E}-01$ & $8.38 E+01$ & $3.90 \mathrm{E}+02$ \\
\hline 48.35 & $8.04 \mathrm{E}-02$ & $4.56 \mathrm{E}-01$ & $2.00 \mathrm{E}+00$ & $2.00 E+00$ \\
\hline 8.17 & $5.89 E-02$ & $6.15 \mathrm{E}-01$ & $3.04 \mathrm{E}+0 \mathrm{I}$ & $E+02$ \\
\hline 0.00 & -02 & & & \\
\hline $26 \mathrm{Tim}$ & $226 \mathrm{Sr}$ & $226 \mathrm{Pu}$ & $226 \mathrm{~Np}$ & $226 \mathrm{U}$ \\
\hline 0 & $6.62 \mathrm{E}+00$ & $6.66 \mathrm{E}+00$ & $1.08 E+03$ & $2.04 \mathrm{E}+03$ \\
\hline 2.45 & $1.73 \mathrm{E}-01$ & $7.92 \mathrm{E}-01$ & $2.26 \mathrm{E}+02$ & $9.99 E+02$ \\
\hline 4.42 & 1.01E-01 & $8.85 \mathrm{E}-01$ & $8.51 E+01$ & $4.98 \mathrm{E}+02$ \\
\hline 8.32 & $8.86 \mathrm{E}-02$ & $4.96 \mathrm{E}-01$ & $6.77 \mathrm{E}+01$ & $4.97 \mathrm{E}+02$ \\
\hline 24.37 & 8.37E-02 & $7.16 \mathrm{E}-01$ & $7.85 E \div 01$ & $3.81 E+02$ \\
\hline 48.37 & $6.73 \mathrm{E}-02$ & $6.95 \mathrm{E}-01$ & $2.00 E \div 00$ & $2.00 \mathrm{E}+\infty$ \\
\hline 168.18 & $6.33 \mathrm{E}-02$ & $6.10 \mathrm{E}-01$ & $2.00 E+00$ & $1.47 E+02$ \\
\hline 240.00 & & $5.23 \mathrm{E}-01$ & $1.90 \mathrm{E}+01$ & \\
\hline \multicolumn{5}{|c|}{ Averages of Duplicate Tests - Bottle \#16 and \#26 } \\
\hline Time & $25 \mathrm{Sr}$ & $25 \mathrm{Pu}$ & $25 \mathrm{~Np}$ & $25 \mathrm{U}$ \\
\hline 0 & $6.62 \mathrm{E}+00$ & $6.66 \mathrm{E}+\infty$ & $1.08 \mathrm{E}+03$ & $2.04 \mathrm{E}+03$ \\
\hline 2.31 & $1.81 \mathrm{E}-01$ & $9.06 \mathrm{E}-01$ & $1.92 \mathrm{E}+02$ & $8.98 \mathrm{E}+02$ \\
\hline 4.4I & $1.07 \mathrm{E}-01$ & $6.33 \mathrm{E}-01$ & $7.42 \mathrm{E}+01$ & $5.32 \mathrm{E}+02$ \\
\hline 8.395 & $9.11 \mathrm{E}-02$ & 6.35E-01 & $6.39 E+01$ & $4.81 \mathrm{E}+02$ \\
\hline 24.36 & 8.41E-02 & $6.93 \mathrm{E}-01$ & $8.11 E+01$ & $3.85 \mathrm{EE}+02$ \\
\hline 48.36 & $7.38 \mathrm{E}-02$ & $5.76 \mathrm{E}-01$ & $2.00 \mathrm{E}+00$ & $2.00 E+00$ \\
\hline 168.175 & $6.11 \mathrm{E}-02$ & $6.12 \mathrm{E}-01$ & $1.62 \mathrm{E}+01$ & $1.27 E+02$ \\
\hline & 94E-02 & $5.68 \mathrm{E}$ & 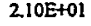 & 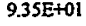 \\
\hline
\end{tabular}
$\begin{array}{lllll}0 & 6.62 \mathrm{E}+00 & 7.50 \mathrm{E}-01 & 7.82 \mathrm{E}+02 & 2.08 \mathrm{E}+03\end{array}$ $\begin{array}{lllll}2.87 & 8.73 \mathrm{E}-02 & 1.45 \mathrm{E}-01 & 1.59 \mathrm{E}+01 & 4.84 \mathrm{E}+02\end{array}$ $\begin{array}{lllll}4.87 & 8.33 \mathrm{E}-02 & 1.72 \mathrm{E}-01 & 2.14 \mathrm{E}+00 & 2.00 \mathrm{E}+00\end{array}$ $\begin{array}{llllll}8.87 & 9.61 \mathrm{E}-02 & 5.28 \mathrm{E}-02 & 2.66 \mathrm{E}+00 & 2.87 \mathrm{E}+02\end{array}$ $25.02 \quad 9.29 \mathrm{E}-02 \quad 5.00 \mathrm{E}-02 \quad 4.34 \mathrm{E}+01 \quad 2.33 \mathrm{E}+02$ $\begin{array}{lllll}48.82 & 7.06 \mathrm{E}-02 & 1.26 \mathrm{E}-01 & 3.08 \mathrm{E}+00 & 1.08 \mathrm{E}+02\end{array}$ $96.50 \quad 7.00 \mathrm{E}-02 \quad 3.91 \mathrm{E}-01 \quad 1.83 \mathrm{E}+01 \quad 8.54 \mathrm{E}+01$ $168.62 \quad 1.42 \mathrm{E}-01 \quad 3.93 \mathrm{E}-01 \quad 4.24 \mathrm{E}+00 \quad 3.11 \mathrm{E}+02$

$426 \mathrm{Time} \quad 426 \mathrm{Sr} \quad 426 \mathrm{Pu} \quad 426 \mathrm{~Np} \quad 426 \mathrm{U}$ $\begin{array}{lllll}0 & 6.62 \mathrm{E}+00 & 7.50 \mathrm{E}-01 & 7.82 \mathrm{E}+02 & 2.08 \mathrm{E}+03\end{array}$ $2.90 \quad 1.38 \mathrm{E}-01 \quad 1.58 \mathrm{E}-0 \mathrm{I} \quad 2.98 \mathrm{E}+0 \mathrm{I} \quad 4.56 \mathrm{E}+02$ $\begin{array}{llllll}4.90 & \text { 1.30E } 01 \quad \text { I.90E } 01 \quad 2.14 \mathrm{E}+00 & 2.00 \mathrm{E}+00\end{array}$

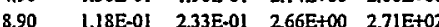
$25.03 \quad 1.07 \mathrm{E}-01 \quad 2.68 \mathrm{E}-01 \quad 3.67 \mathrm{E}+01 \quad 2.00 \mathrm{E}+02$ $\begin{array}{llllll}48.83 & 8.02 \mathrm{E}-02 & \text { l.18E-01 } & 3.08 \mathrm{E}+00 & 1.05 \mathrm{E}+02\end{array}$ $\begin{array}{lllll}96.43 & 7.50 \mathrm{E}-02 & 5.37 \mathrm{E}-01 & 3.64 \mathrm{E}+00 & 1.25 \mathrm{E}+02\end{array}$ $168.63 \quad 2.39 \mathrm{E}-01 \quad 3.53 \mathrm{E}-01 \quad 4.24 \mathrm{E}+00 \quad 1.03 \mathrm{E}+02$

$45 \mathrm{Time} \quad 45 \mathrm{Sr} \quad 45 \mathrm{Pu} \quad 45 \mathrm{~Np} \quad 45 \mathrm{U}$ $\begin{array}{llllll}0 & 6.62 \mathrm{E}+00 & 7.50 \mathrm{E}-01 & 7.82 \mathrm{E}+02 & 2.08 \mathrm{E}+03\end{array}$ $2885 \quad 1.13 \mathrm{E}-01 \quad 1.52 \mathrm{E}-01 \quad 2.28 \mathrm{E}+01 \quad 4.70 \mathrm{E}+02$ $\begin{array}{lllll}4.885 & 1.07 \mathrm{E}-01 & 1.81 \mathrm{E}-01 & 2.14 \mathrm{E}+00 & 2.00 \mathrm{E}+00\end{array}$ $\begin{array}{lllll}8.885 & 1.07 \mathrm{E}-01 & 1.43 \mathrm{E}-01 & 2.66 \mathrm{E}+00 & 2.79 \mathrm{E}+02\end{array}$ $\begin{array}{llllll}25.025 & 9.99 \mathrm{E}-02 & 1.59 \mathrm{E}-01 & 4.00 \mathrm{E}+01 & 2.17 \mathrm{E}+02\end{array}$

$\begin{array}{lllll}48.825 & 7.54 \mathrm{E}-02 & 1.22 \mathrm{E}-01 & 3.08 \mathrm{E}+00 & 1.07 \mathrm{E}+02\end{array}$

$96.465 \quad 7.25 \mathrm{E}-02 \quad 4.64 \mathrm{E}-01 \quad 1.10 \mathrm{E}+01 \quad 1.05 \mathrm{E}+02$ $\begin{array}{lllll}168.625 & 1.90 \mathrm{E}-01 & 3.73 \mathrm{E}-01 & 4.24 \mathrm{E}+00 & 2.07 \mathrm{E}+02\end{array}$

$\begin{array}{ccccc}616 \text { Time } & 616 \mathrm{Sr} & 616 \mathrm{Pu} & 616 \mathrm{~Np} & 616 \mathrm{U} \\ 0 & 6.62 \mathrm{E}+00 & 7.50 \mathrm{E}-01 & 4.72 \mathrm{E}+02 & 1.84 \mathrm{E}+03 \\ 2.08 & 1.11 \mathrm{E}-01 & 4.85 \mathrm{E}-02 & 2.22 \mathrm{E}+00 & 2.90 \mathrm{E}+02 \\ 4.05 & 1.16 \mathrm{E}-01 & 1.40 \mathrm{E}-02 & 2.18 \mathrm{E}+00 & 2.13 \mathrm{E}+02 \\ 8.03 & 9.51 \mathrm{E}-02 & 5.37 \mathrm{E}-02 & 2.50 \mathrm{E}+00 & 1.43 \mathrm{E}+02 \\ 24.13 & 9.59 \mathrm{E}-02 & 5.59 \mathrm{E}-02 & 2.78 \mathrm{E}+00 & 1.03 \mathrm{E}+02 \\ 48.07 & 1.08 \mathrm{E}-01 & 1.47 \mathrm{E}-01 & 9.92 \mathrm{E}+00 & 1.25 \mathrm{E}+02 \\ 96.00 & 9.44 \mathrm{E}-02 & 1.20 \mathrm{E}-02 & 3.12 \mathrm{E}+00 & 9.80 \mathrm{E}+01 \\ 167.87 & 1.02 \mathrm{E}-01 & 1.46 \mathrm{E}-01 & 3.56 \mathrm{E}+00 & 8.98 \mathrm{E}+01 \\ & & & & \\ 626 \mathrm{Time} & 626 \mathrm{Sr} & 626 \mathrm{Pu} & 626 \mathrm{~Np} & 626 \mathrm{U} \\ 0 & 6.62 \mathrm{E}+00 & 7.50 \mathrm{E}-01 & 4.72 \mathrm{E}+02 & 1.84 \mathrm{E}+03 \\ 2.10 & 1.24 \mathrm{E}-01 & 7.19 \mathrm{E}-02 & 2.22 \mathrm{E}+00 & 2.73 \mathrm{E}+02 \\ 4.07 & 1.20 \mathrm{E}-01 & 1.08 \mathrm{E}-01 & 2.18 \mathrm{E}+00 & 2.57 \mathrm{E}+02 \\ 8.03 & 7.23 \mathrm{E}-02 & 1.20 \mathrm{E}-01 & 2.50 \mathrm{E}+00 & 1.27 \mathrm{E}+02 \\ 24.15 & 1.04 \mathrm{E}-01 & 1.14 \mathrm{E}-01 & 2.78 \mathrm{E}+00 & 1.31 \mathrm{E}+02 \\ 49.07 & 9.46 \mathrm{E}-02 & 1.17 \mathrm{E}-01 & 8.77 \mathrm{E}+00 & 1.15 \mathrm{E}+02 \\ 96.02 & 1.02 \mathrm{E}-01 & & 3.12 \mathrm{E}+00 & 8.55 \mathrm{E}+01 \\ 167.88 & 9.71 \mathrm{E}-02 & 1.90 \mathrm{E}-01 & 3.56 \mathrm{E}+00 & 1.16 \mathrm{E}+02 \\ & & & & \\ & & & & \\ 65 \mathrm{Time} & 65 \mathrm{Sr} & 65 \mathrm{Pu} & 65 \mathrm{~Np} & 65 \mathrm{U} \\ 0 & 6.62 \mathrm{E}+00 & 7.50 \mathrm{E}-01 & 4.72 \mathrm{E}+02 & 1.84 \mathrm{E}+03 \\ 2.09 & 1.17 \mathrm{E}-01 & 6.02 \mathrm{E}-02 & 2.22 \mathrm{E}+00 & 2.81 \mathrm{E}+02 \\ 4.06 & 1.18 \mathrm{E}-01 & 6.11 \mathrm{E}-02 & 2.18 \mathrm{E}+00 & 2.35 \mathrm{E}+02 \\ 8.03 & 8.37 \mathrm{E}-02 & 8.71 \mathrm{E}-02 & 2.50 \mathrm{E}+00 & 1.35 \mathrm{E}+02 \\ 24.14 & 9.99 \mathrm{E}-02 & 8.52 \mathrm{E}-02 & 2.78 \mathrm{E}+00 & 1.17 \mathrm{E}+02 \\ 48.57 & 1.01 \mathrm{E}-01 & 1.32 \mathrm{E}-01 & 9.34 \mathrm{E}+00 & 1.20 \mathrm{E}+02 \\ 96.01 & 9.80 \mathrm{E}-02 & 1.20 \mathrm{E}-02 & 3.12 \mathrm{E}+00 & 9.18 \mathrm{E}+01 \\ 167.875 & 9.96 \mathrm{E}-02 & 1.68 \mathrm{E}-01 & 3.56 \mathrm{E}+00 & 1.03 \mathrm{E}+02 \\ & & & & \end{array}$




\section{Appendix 14.}

\section{Concentration versus Time Data for Tests at}

46.0 $\mathrm{M} \mathrm{Na}^{+}, 1.1 \mathrm{~g} / \mathrm{L} \mathrm{MST}$, Low Activity Solution, NaTPB or Sludge Added (Bottles \# 21 and 14)

(Units of Time $=$ hours; Units of Concentration $=\mu \mathrm{g} / \mathrm{L}$ )

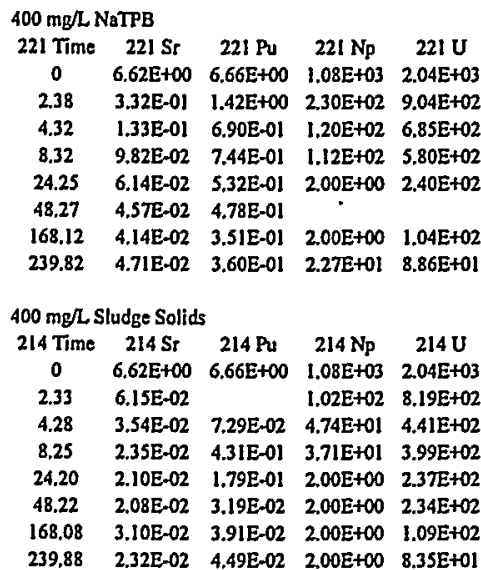

$\begin{array}{ccccc}621 \text { Time } & 621 \mathrm{Sr} & 621 \mathrm{Pu} & 621 \mathrm{~Np} & 621 \mathrm{U} \\ 0 & 6.62 \mathrm{E}+00 & 7.50 \mathrm{E}-01 & 4.72 \mathrm{E}+02 & 1.84 \mathrm{E}+03 \\ 2.27 & 2.95 \mathrm{E}-01 & 3.08 \mathrm{E}-02 & 2.22 \mathrm{E}+00 & 3.73 \mathrm{E}+02 \\ 4.23 & 1.19 \mathrm{E}-01 & 7.03 \mathrm{E}-02 & 2.18 \mathrm{E}+00 & 1.84 \mathrm{E}+02 \\ 8.30 & 9.18 \mathrm{E}-02 & 6.74 \mathrm{E}-02 & 2.50 \mathrm{E}+00 & 1.28 \mathrm{E}+02 \\ 24.12 & 9.52 \mathrm{E}-02 & 9.45 \mathrm{E}-02 & 2.78 \mathrm{E}+00 & 1.02 \mathrm{E}+02 \\ 48.37 & 8.77 \mathrm{E}-02 & 1.92 \mathrm{E}-01 & 3.12 \mathrm{E}+00 & 1.27 \mathrm{E}+02 \\ 96.10 & 1.00 \mathrm{E}-01 & 3.03 \mathrm{E}-01 & 3.12 \mathrm{E}+00 & 1.01 \mathrm{E}+02 \\ 167.92 & 1.61 \mathrm{E}-01 & 1.27 \mathrm{E}-01 & 3.56 \mathrm{E}+00 & 1.22 \mathrm{E}+02 \\ & & & & \\ & & & & \\ 614 \mathrm{Time} & 614 \mathrm{Sr} & 614 \mathrm{Pu} & 614 \mathrm{~Np} & 614 \mathrm{U} \\ 0 & 6.62 \mathrm{E}+00 & 7.50 \mathrm{E}-01 & 4.72 \mathrm{E}+02 & 1.84 \mathrm{E}+03 \\ 2.20 & 2.46 \mathrm{E}-01 & 2.06 \mathrm{E}-02 & 2.22 \mathrm{E}+00 & 2.71 \mathrm{E}+02 \\ 4.18 & 1.41 \mathrm{E}-01 & 5.44 \mathrm{E}-02 & 2.18 \mathrm{E}+00 & 2.24 \mathrm{E}+02 \\ 8.23 & 1.05 \mathrm{E}-01 & 6.30 \mathrm{E}-02 & 2.50 \mathrm{E}+00 & 1.70 \mathrm{E}+02 \\ 24.07 & 1.14 \mathrm{E}-01 & 7.17 \mathrm{E}-02 & 2.78 \mathrm{E}+00 & 1.26 \mathrm{E}+02 \\ 48.08 & 1.29 \mathrm{E}-01 & 7.23 \mathrm{E}-02 & 2.73 \mathrm{E}+01 & 1.49 \mathrm{E}+02 \\ 96.03 & 1.68 \mathrm{E}-01 & 1.01 \mathrm{E}-02 & 2.34 \mathrm{E}+01 & 9.52 \mathrm{E}+01 \\ 167.85 & 1.81 \mathrm{E}-01 & 8.71 \mathrm{E}-02 & 3.56 \mathrm{E}+00 & 7.48 \mathrm{E}+01\end{array}$




\section{Appendix 15.}

Concentration versus Time Data for Tests at 7.5 $\mathrm{M} \mathrm{Na}^{+}, 0.2 \mathrm{~g} / \mathrm{L} \mathrm{MST,} L$ ow Activity Solution (Bottles \# 15 and 18)

(Units of Time $=$ hours; Units of Concentration $=\mu \mathrm{g} / \mathrm{L}$ )

$\begin{array}{ccccc}215 \text { Time } & 215 \mathrm{Sr} & 215 \mathrm{Pu} & 215 \mathrm{~Np} & 215 \mathrm{U} \\ 0 & 828 \mathrm{E}+00 & 9.83 \mathrm{E}+00 & 1.70 \mathrm{E}+03 & 2.56 \mathrm{E}+03 \\ 2.35 & 3.48 \mathrm{E}+00 & 1.15 \mathrm{E}+01 & 1.21 \mathrm{E}+03 & 224 \mathrm{E}+03 \\ 430 & 2.66 \mathrm{E}+00 & 1.03 \mathrm{E}+01 & 9.96 \mathrm{E}+02 & 2.18 \mathrm{E}+03 \\ 827 & 2.32 \mathrm{E}+00 & 1.09 \mathrm{E}+01 & 1.04 \mathrm{E}+03 & 240 \mathrm{E}+03 \\ 24.22 & 1.73 \mathrm{E}+00 & 1.02 \mathrm{E}+01 & 8.90 \mathrm{E}+02 & 2.20 \mathrm{E}+03 \\ 48.23 & 1.65 \mathrm{E}+00 & 8.18 \mathrm{E}+00 & & \\ 168.08 & 1.40 \mathrm{E}+00 & 8.93 \mathrm{E}+00 & 5.76 \mathrm{E}+02 & 1.91 \mathrm{E}+03 \\ 239.88 & 1.34 \mathrm{E}+00 & 7.97 \mathrm{E}+00 & 5.22 \mathrm{E}+02 & 1.90 \mathrm{E}+03\end{array}$

218 Time $218 \mathrm{Sr} \quad 218 \mathrm{Pu} \quad 218 \mathrm{~Np} \quad 218 \mathrm{U}$

$\begin{array}{lllll}0 & 828 \mathrm{E}+00 & 9.83 \mathrm{E}+\infty & 1.70 \mathrm{E}+03 & 2.56 \mathrm{E}+03\end{array}$

$\begin{array}{lllll}2.60 & 3.63 \mathrm{E}+00 & 1.15 \mathrm{E}+0 \mathrm{l} & 1.26 \mathrm{E}+03 & 2.55 \mathrm{E}+03\end{array}$

$\begin{array}{lllll}4.32 & 2.67 \mathrm{E}+00 & 9.41 \mathrm{E}+00 & 1.13 \mathrm{E}+03 & 2.39 \mathrm{E}+03\end{array}$

$830 \quad 238 E+00 \quad 1.16 E+01 \quad 1.14 E+03 \quad 2.50 E+03$

$\begin{array}{llllll}24.23 & 1.85 \mathrm{E}+00 & 9.22 \mathrm{E}+00 & 8.49 \mathrm{E}+02 & 2.24 \mathrm{E}+03\end{array}$

$\begin{array}{lllll}48.25 & 1.67 E+00 & 8.36 E+00 & 2.00 E+00 & 200 E+00\end{array}$

$\begin{array}{llllll}168.10 & 1.44 \mathrm{E}+00 & 7.45 \mathrm{E}+00 & 5.92 \mathrm{E}+02 & 2.07 \mathrm{E}+03\end{array}$

$\begin{array}{lllll}239.92 & 1.39 \mathrm{E}+00 & 8.06 \mathrm{E}+00 & 4.76 \mathrm{E}+02 & 1.78 \mathrm{E}+03\end{array}$

Averages of Duplicate Tests - Bottle \#15 and \#18

$$
\text { Time } 25 \mathrm{Sr} 25 \mathrm{Pu} 25 \mathrm{~Np} 25 \mathrm{U}
$$

$\begin{array}{ccccc}\text { Time } & 25 \mathrm{Sr} & 25 \mathrm{Pu} & 25 \mathrm{~Np} & 25 \mathrm{U} \\ 0 & 8.28 \mathrm{E}+00 & 9.83 \mathrm{E}+00 & 1.70 \mathrm{E}+03 & 2.56 \mathrm{E}+03\end{array}$

$\begin{array}{lllll}2.475 & 3.56 \mathrm{E}+00 & 1.15 \mathrm{E}+01 & 1.24 \mathrm{E}+03 & 2.40 \mathrm{E}+03\end{array}$

$4.31 \quad 267 \mathrm{E}+00 \quad 9.86 \mathrm{E}+00 \quad 1.06 \mathrm{E}+03 \quad 2.28 \mathrm{E}+03$

$8285 \quad 235 E+00 \quad 1.13 E+01 \quad 1.09 E+03 \quad 245 E+03$

$\begin{array}{llllll}24225 & 1.79 \mathrm{E}+00 & 9.69 \mathrm{E}+00 & 8.69 \mathrm{E}+02 & 2.22 \mathrm{E}+03\end{array}$

$\begin{array}{llllll}48.24 & 1.66 \mathrm{E}+\infty & 8.27 \mathrm{E}+00 & 2.00 \mathrm{E}+00 & 2.00 \mathrm{E}+00\end{array}$

$\begin{array}{lllll}168.09 & 1.42 \mathrm{E}+00 & 8.19 \mathrm{E}+00 & 5.84 \mathrm{E}+02 & 1.99 \mathrm{E}+03\end{array}$

$\begin{array}{lllll}239.9 & 1.36 \mathrm{E}+00 & 8.01 \mathrm{E}+00 & 499 \mathrm{E}+02 & 1.84 \mathrm{E}+03\end{array}$

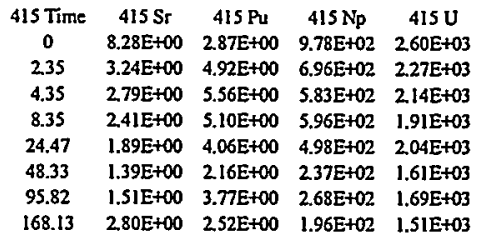

418 Time $418 \mathrm{Sr} \quad 418 \mathrm{Pu} \quad 418 \mathrm{~Np} \quad 418 \mathrm{U}$

$\begin{array}{lllll}0 & 8.28 \mathrm{E}+00 & 2.87 \mathrm{E}+00 & 9.78 \mathrm{E}+02 & 260 \mathrm{E}+03\end{array}$

$\begin{array}{lllll}2.40 & 3.46 \mathrm{E}+00 \quad 4.76 \mathrm{E}+00 & 7.76 \mathrm{E}+02 & 2.48 \mathrm{E}+03\end{array}$

$\begin{array}{lllll}4.40 & 2.90 \mathrm{E}+\infty 0 & 5.69 \mathrm{E}+\infty 0 & 6.31 \mathrm{E}+02 & 2.32 \mathrm{E}+03\end{array}$

$\begin{array}{lllll}8.40 & 249 E+00 & 5.81 E+00 & 5.67 E+02 & 1.96 E+03\end{array}$

$24.53 \quad 201 E+00 \quad 5.09 E+00 \quad 4.81 E+02 \quad 208 E+03$

$\begin{array}{llllll}48.38 & 1.42 E+00 & 2.83 E+00 & 2.47 E+02 & 1.74 E+03\end{array}$

$\begin{array}{llllll}95.88 & 1.27 \mathrm{E}+\infty & 3.04 \mathrm{E}+\infty & 2.53 \mathrm{E}+02 & 1.48 \mathrm{E}+03\end{array}$

$\begin{array}{lllll}168.17 & 3.05 \mathrm{E}+00 & 285 \mathrm{E}+00 & 2.77 \mathrm{E}+02 & 1.59 \mathrm{E}+03\end{array}$

45 Time $45 \mathrm{Sr} \quad 45 \mathrm{Pu} \quad 45 \mathrm{~Np} \quad 45 \mathrm{U}$

$\begin{array}{lllll}0 & 8.28 \mathrm{E}+00 & 2.87 \mathrm{E}+00 & 9.78 \mathrm{E}+02 & 2.60 \mathrm{E}+03\end{array}$

$\begin{array}{llllll}2.375 & 3.35 \mathrm{E}+00 & 4.84 \mathrm{E}+00 & 7.36 \mathrm{E}+02 & 237 \mathrm{E}+03\end{array}$

$\begin{array}{lllll}4.375 & 2.84 E+00 & 5.62 \mathrm{E}+\infty & 6.07 \mathrm{E}+02 & 2.23 \mathrm{E}+03\end{array}$

$\begin{array}{llllll}8.375 & 2.45 \mathrm{E}+00 & 5.46 \mathrm{E}+\infty & 5.82 \mathrm{E}+02 & 1.94 \mathrm{E}+03\end{array}$

$\begin{array}{llllll}24.5 & 1.95 \mathrm{E}+\infty & 4.57 \mathrm{E}+00 & 4.89 \mathrm{E}+02 & 2.06 \mathrm{E}+03\end{array}$

$\begin{array}{llllll}48.355 & 1.41 \mathrm{E}+00 & 2.50 \mathrm{E}+00 & 2.42 \mathrm{E}+02 & 1.68 \mathrm{E}+03\end{array}$

$\begin{array}{lllll}95.85 & 1.39 \mathrm{E}+00 & 3.40 \mathrm{E}+00 & 2.60 \mathrm{E}+02 & 1.58 \mathrm{E}+03\end{array}$

$\begin{array}{lllll}168.15 & 2.93 \mathrm{E}+00 & 2.69 \mathrm{E}+00 & 2.36 \mathrm{E}+02 & 1.55 \mathrm{E}+03\end{array}$

$\begin{array}{ccccc}615 \text { Time } & 615 \mathrm{Sr} & 615 \mathrm{Pu} & 615 \mathrm{~Np} & 615 \mathrm{U} \\ 0 & 8.28 \mathrm{E}+00 & 4.69 \mathrm{E}-01 & 5.90 \mathrm{E}+02 & 2.30 \mathrm{E}+03 \\ 2.20 & 2.32 \mathrm{E}+00 & 1.12 \mathrm{E}+00 & 2.55 \mathrm{E}+02 & 1.90 \mathrm{E}+03 \\ 4.18 & 1.94 \mathrm{E}+00 & 1.01 \mathrm{E}+00 & 2.14 \mathrm{E}+02 & 2.00 \mathrm{E}+03 \\ 8.23 & 1.60 \mathrm{E}+00 & 6.33 \mathrm{E}-01 & 1.75 \mathrm{E}+02 & 1.60 \mathrm{E}+03 \\ 24.07 & 1.71 \mathrm{E}+00 & 9.22 \mathrm{E}-01 & 1.86 \mathrm{E}+02 & 1.55 \mathrm{E}+03 \\ 48.12 & 1.40 \mathrm{E}+00 & 5.11 \mathrm{E}-01 & 1.39 \mathrm{E}+02 & 1.48 \mathrm{E}+03 \\ 96.03 & 1.70 \mathrm{E}+00 & 4.18 \mathrm{E}-01 & 1.59 \mathrm{E}+02 & 1.35 \mathrm{E}+03 \\ 167.85 & 1.38 \mathrm{E}+00 & 3.73 \mathrm{E}-01 & 1.83 \mathrm{E}+02 & 1.27 \mathrm{E}+03 \\ & & & & \\ 618 \mathrm{Time} & 618 \mathrm{Sr} & 618 \mathrm{Pu} & 618 \mathrm{~Np} & 618 \mathrm{U} \\ 0 & 8.28 \mathrm{E}+00 & 4.69 \mathrm{E}-01 & 5.90 \mathrm{E}+02 & 2.30 \mathrm{E}+03 \\ 2.25 & 2.56 \mathrm{E}+00 & 1.44 \mathrm{E}+00 & 3.02 \mathrm{E}+02 & 2.01 \mathrm{E}+03 \\ 4.22 & 1.83 \mathrm{E}+00 & 9.20 \mathrm{E}-01 & 1.80 \mathrm{E}+02 & 1.77 \mathrm{E}+03 \\ 8.28 & 1.53 \mathrm{E}+00 & 3.32 \mathrm{E}-01 & 1.92 \mathrm{E}+02 & 1.66 \mathrm{E}+03 \\ 24.10 & 1.59 \mathrm{E}+00 & 1.06 \mathrm{E}+00 & 1.86 \mathrm{E}+02 & 1.37 \mathrm{E}+03 \\ 48.17 & 1.42 \mathrm{E}+00 & 5.92 \mathrm{E}-01 & 1.51 \mathrm{E}+02 & 1.54 \mathrm{E}+03 \\ 96.08 & 1.38 \mathrm{E}+00 & 5.92 \mathrm{E}-01 & 1.36 \mathrm{E}+02 & 1.43 \mathrm{E}+03 \\ 167.90 & 1.30 \mathrm{E}+00 & 5.35 \mathrm{E}-01 & 1.58 \mathrm{E}+02 & 1.36 \mathrm{E}+03 \\ & & & & \\ & & & & \\ 65 \mathrm{Time} & 65 \mathrm{Sr} & 65 \mathrm{Pu} & 65 \mathrm{~Np} & 65 \mathrm{U} \\ 0 & 8.28 \mathrm{E}+00 & 4.69 \mathrm{E}-01 & 5.90 \mathrm{E}+02 & 2.30 \mathrm{E}+03 \\ 2.225 & 2.44 \mathrm{E}+00 & 1.28 \mathrm{E}+00 & 2.78 \mathrm{E}+02 & 1.96 \mathrm{E}+03 \\ 42 & 1.89 \mathrm{E}+00 & 9.65 \mathrm{E}-01 & 1.97 \mathrm{E}+02 & 1.89 \mathrm{E}+03 \\ 8255 & 1.56 \mathrm{E}+00 & 4.83 \mathrm{E}-01 & 1.83 \mathrm{E}+02 & 1.63 \mathrm{E}+03 \\ 24.085 & 1.65 \mathrm{E}+00 & 9.93 \mathrm{E}-01 & 1.86 \mathrm{E}+02 & 1.46 \mathrm{E}+03 \\ 48.145 & 1.41 \mathrm{E}+00 & 5.52 \mathrm{E}-01 & 1.45 \mathrm{E}+02 & 1.51 \mathrm{E}+03 \\ 96.055 & 1.54 \mathrm{E}+00 & 5.05 \mathrm{E}-01 & 1.48 \mathrm{E}+02 & 1.39 \mathrm{E}+03 \\ 167.875 & 1.34 \mathrm{E}+00 & 4.54 \mathrm{E}-01 & 1.71 \mathrm{E}+02 & 1.32 \mathrm{E}+03\end{array}$




\section{Appendix 16. \\ Concentration versus Time Data for Tests at \\ 7.5 $\mathrm{M} \mathrm{Na}^{+}, 2.0 \mathrm{~g} / \mathrm{L} \mathrm{MST,} \mathrm{Low} \mathrm{Activity} \mathrm{Solution}$ \\ (Bottles \# 08 and 23) \\ (Units of Time $=$ hours; Units of Concentration $=\mu \mathrm{g} / \mathrm{L}$ )}

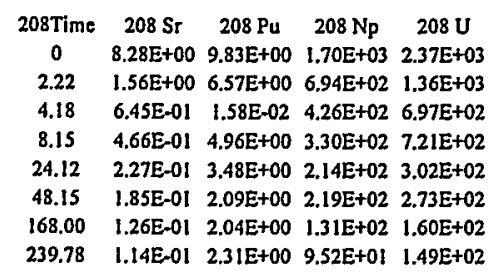

223 Time $223 \mathrm{Sr} \quad 223 \mathrm{Pu} \quad 223 \mathrm{~Np} \quad 223 \mathrm{U}$

$\begin{array}{llllll}0 & 8.28 \mathrm{E}+00 \quad 9.83 \mathrm{E}+00 \quad 1.70 \mathrm{E}+03 \quad 2.37 \mathrm{E}+03\end{array}$

$\begin{array}{lllll}2.40 & 1.17 \mathrm{E}+00 & 6.47 \mathrm{E}+00 & 8.34 \mathrm{E}+02 & 1.40 \mathrm{E}+03\end{array}$

$\begin{array}{llll}4.35 & 6.14 \mathrm{E}-01 & 4.86 \mathrm{E}+02 & 8.56 \mathrm{E}+02\end{array}$

$\begin{array}{llll}8.37 \quad 4.40 \mathrm{E}-01 & 5.04 \mathrm{E}+00 \quad 3.56 \mathrm{E}+02 \quad 5.37 \mathrm{E}+02\end{array}$

$\begin{array}{lllll}24.30 & 2.14 \mathrm{E}-01 & 2.67 \mathrm{E}+00 & 1.63 \mathrm{E}+02 & 2.31 \mathrm{E}+02\end{array}$

$48.30 \quad 1.82 \mathrm{E}-01 \quad 2.60 \mathrm{E}+00$

$168.13 \quad 1.25 \mathrm{E}-01 \quad 1.32 \mathrm{E}+00 \quad 1.19 \mathrm{E}+02 \quad 1.70 \mathrm{E}+02$

$239.97 \quad 1.20 \mathrm{E}-01 \quad 2.17 \mathrm{E}+00 \quad 9.39 \mathrm{E}+01 \quad 1.24 \mathrm{E}+02$

Averages of Duplicate Tests - Bottle $\# 08$ and $\$ 23$

Time $25 \mathrm{Sr} 25 \mathrm{Pu} 25 \mathrm{~Np} 25 \mathrm{U}$

$\begin{array}{llllll}0 & 8.28 E+00 & 9.83 E+00 & 1.70 E+03 & 2.37 E+03\end{array}$

$2.31 \quad 1.36 \mathrm{E}+00 \quad 6.52 \mathrm{E}+00 \quad 7.64 \mathrm{E}+02 \quad 1.38 \mathrm{E}+03$

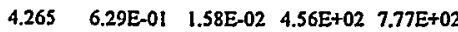

$\begin{array}{llll}8.26 \quad 4.53 \mathrm{E}-01 & 5.00 \mathrm{E}+00 \quad 3.43 \mathrm{E}+02 \quad 6.29 \mathrm{E}+02\end{array}$

$24.21 \quad 2.20 \mathrm{E}-01 \quad 3.07 \mathrm{E}+00 \quad 1.88 \mathrm{E}+02 \quad 2.67 \mathrm{E}+02$

$\begin{array}{lllll}48.225 & 1.84 \mathrm{E}-01 & 2.35 \mathrm{E}+00 & 2.19 \mathrm{E}+02 & 2.73 \mathrm{E}+02\end{array}$

$168.065 \quad 1.25 \mathrm{E}-01 \quad 1.68 \mathrm{E}+00 \quad 1.25 \mathrm{E}+02 \quad 1.65 \mathrm{E}+02$

$239.875 \quad 1.17 \mathrm{E}-01 \quad 2.24 \mathrm{E}+00 \quad 9.45 \mathrm{E}+01 \quad 1.37 \mathrm{E}+02$

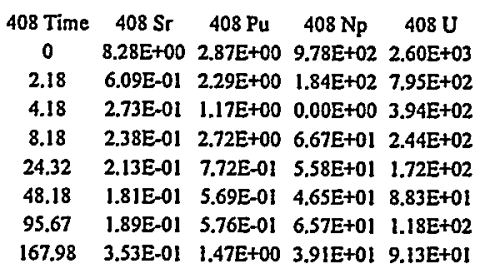

423 Time $423 \mathrm{Sr} \quad 423 \mathrm{Pu} \quad 423 \mathrm{~Np} \quad 423 \mathrm{U}$

$\begin{array}{lllll}0 & 8.28 \mathrm{E}+00 & 2.87 \mathrm{E}+00 & 9.78 \mathrm{E}+02 & 2.60 \mathrm{E}+03\end{array}$

$\begin{array}{llll}2.55 & 5.25 \mathrm{E}-01 & 1.84 \mathrm{E}+02 & 6.10 \mathrm{E}+02\end{array}$

$4.55 \quad 3.05 \mathrm{E}-01 \quad 1.67 \mathrm{E}+\infty$

$8.55 \quad 2.53 \mathrm{E}-01 \quad 1.21 \mathrm{E}+00 \quad 7.90 \mathrm{E}+01 \quad 2.39 \mathrm{E}+02$

$\begin{array}{llllll}24.67 & 2.16 \mathrm{E}-01 & 6.12 \mathrm{E}-01 & 1.01 \mathrm{E}+03 & 8.22 \mathrm{E}+02\end{array}$

48.52 1.75E-01 2.56E-01 5.41E+01 133E+02

$96.02 \quad 1.88 \mathrm{E}-01 \quad 5.90 \mathrm{E}-01 \quad 3.87 \mathrm{E}+01 \quad 1.01 \mathrm{E}+02$

$\begin{array}{lllll}168.28 & 3.39 \mathrm{E}-01 & 5.55 \mathrm{E}-01 & 4.85 \mathrm{E}+01 & 9.84 \mathrm{E}+01\end{array}$

$45 \mathrm{Time} \quad 45 \mathrm{Sr} \quad 45 \mathrm{Pu} \quad 45 \mathrm{~Np} \quad 45 \mathrm{U}$

$\begin{array}{lllllllll}0 & 8.28 \mathrm{E}+00 & 2.87 \mathrm{E}+00 & 9.78 \mathrm{E}+02 & 2.60 \mathrm{E}+03\end{array}$

$2.365 \quad 5.67 \mathrm{E}-01 \quad 2.29 \mathrm{E}+00 \quad 1.84 \mathrm{E}+02 \quad 7.03 \mathrm{E}+02$

$\begin{array}{llllll}4.365 & 2.89 \mathrm{E}-01 & 1.42 \mathrm{E}+00 & 0.00 \mathrm{E}+00 & 3.94 \mathrm{E}+02\end{array}$

$\begin{array}{lllll}8.365 & 2.46 \mathrm{E}-01 & 1.97 \mathrm{E}+00 & 7.29 \mathrm{E}+01 & 2.42 \mathrm{E}+02\end{array}$

$24.495 \quad 2.15 \mathrm{E}-01 \quad 6.92 \mathrm{E}-01 \quad 5.34 \mathrm{E}+02 \quad 4.97 \mathrm{E}+02$

48.35 1.78E-01 4.12E-01 5.03E+01 1.10E+02

$\begin{array}{lllll}95.845 & 1.89 \mathrm{E}-01 & 5.83 \mathrm{E}-01 & 5.22 \mathrm{E}+01 & 1.09 \mathrm{E}+02\end{array}$

$168.13 \quad 3.46 \mathrm{E}-01 \quad 1.0 \mathrm{IE}+00 \quad 4.38 \mathrm{E}+01 \quad 9.48 \mathrm{E}+01$
608 Time $608 \mathrm{Sr} \quad 608 \mathrm{Pu} \quad 608 \mathrm{~Np} \quad 608 \mathrm{U}$ $\begin{array}{lllll}0 & 8.28 \mathrm{E}+00 \quad 4.69 \mathrm{E}-01 \quad 5.90 \mathrm{E}+02 & 2.30 \mathrm{E}+03\end{array}$ $2.10 \quad 6.68 \mathrm{E}-01 \quad 3.30 \mathrm{E}-01 \quad 4.43 \mathrm{E}+01 \quad 3.03 \mathrm{E}+02$ $4.10 \quad 3.59 \mathrm{E}-01 \quad 1.92 \mathrm{E}-01 \quad 3.10 \mathrm{E}+01 \quad 1.80 \mathrm{E}+02$ $8.13 \quad 3.07 \mathrm{E}-01 \quad 1.28 \mathrm{E}-01 \quad 2.50 \mathrm{E}+00 \quad 1.37 \mathrm{E}+02$ 24.02 2.55E-01 2.84E-01 2.78E+00

$48.02 \quad 2.35 \mathrm{E}-01 \quad 3.20 \mathrm{E}-01 \quad 1.74 \mathrm{E}+01 \quad 1.26 \mathrm{E}+02$ $95.97 \quad 2.34 \mathrm{E}-01 \quad 2.03 \mathrm{E}-01 \quad 3.12 \mathrm{E}+00 \quad 1.13 \mathrm{E}+02$ $167.78 \quad 1.36 \mathrm{E}-01 \quad 2.11 \mathrm{E}-01 \quad 3.56 \mathrm{E}+00 \quad 9.71 \mathrm{E}+01$

623 Time $623 \mathrm{Sr} 623 \mathrm{Pu} 623 \mathrm{~Np} 623 \mathrm{U}$ $\begin{array}{llllll}0 & 8.28 \mathrm{E}+00 & 4.69 \mathrm{E}-01 & 5.90 \mathrm{E}+02 & 2.30 \mathrm{E}+03\end{array}$ $2.27 \quad 7.33 \mathrm{E}-01 \quad 1.55 \mathrm{E}-02 \quad 5.84 \mathrm{E}+01 \quad 4.96 \mathrm{E}+02$ $\begin{array}{llllll}4.23 & 4.22 \mathrm{E}-01 \quad 1.71 \mathrm{E}-01 & 2.18 \mathrm{E}+00 & 3.04 \mathrm{E}+02\end{array}$ $8.33 \quad 3.31 \mathrm{E}-01 \quad 1.63 \mathrm{E}-01 \quad 2.50 \mathrm{E}+00 \quad 1.20 \mathrm{E}+02$ $24.13 \quad 3.84 \mathrm{E}-01 \quad 2.27 \mathrm{E}-01 \quad 2.78 \mathrm{E}+00 \quad 1.04 \mathrm{E}+02$ $48.18 \quad 2.16 \mathrm{E}-01 \quad 5.28 \mathrm{E}-02 \quad 1.18 \mathrm{E}+01 \quad 1.04 \mathrm{E}+02$ $96.13 \quad 2.79 \mathrm{E}-01 \quad 1.46 \mathrm{E}-01 \quad 3.12 \mathrm{E}+00 \quad 1.12 \mathrm{E}+02$ $\begin{array}{lllll}167.92 & 1.77 E-01 & 1.45 E-01 & 3.56 E+00 & 1.21 E+02\end{array}$

$65 \mathrm{Time} \quad 65 \mathrm{Sr} \quad 65 \mathrm{Pu} \quad 65 \mathrm{~Np} \quad 65 \mathrm{U}$ $\begin{array}{lllll}0 & 8.28 E+00 \quad 4.69 E-01 & 5.90 E+02 & 2.30 E+03\end{array}$ $2.185 \quad 7.00 \mathrm{E}-01 \quad 1.73 \mathrm{E}-01 \quad 5.13 \mathrm{E}+01 \quad 3.99 \mathrm{E}+02$ $\begin{array}{lllll}4.165 & 3.90 \mathrm{E}-01 & 1.82 \mathrm{E}-01 & 1.66 \mathrm{E}+01 & 2.42 \mathrm{E}+02\end{array}$ $\begin{array}{lllll}8.23 & 3.19 \mathrm{E}-01 \quad \mathrm{I} & \mathrm{I} .45 \mathrm{E}-01 & 2.50 \mathrm{E}+00 & 1.28 \mathrm{E}+02\end{array}$ $24.075 \quad 3.19 \mathrm{E}-01 \quad 2.55 \mathrm{E}-01 \quad 2.78 \mathrm{E}+00 \quad 1.04 \mathrm{E}+02$ $48.1 \quad 2.25 \mathrm{E}-01 \quad 1.86 \mathrm{E}-01 \quad 1.46 \mathrm{E}+01 \quad 1.15 \mathrm{E}+02$ $96.05 \quad 2.56 \mathrm{E}-01 \quad 1.74 \mathrm{E}-01 \quad 3.12 \mathrm{E}+00 \quad 1.13 \mathrm{E}+02$ $167.85 \quad 1.56 \mathrm{E}-01 \quad 1.78 \mathrm{E}-01 \quad 3.56 \mathrm{E}+00 \quad 1.09 \mathrm{E}+02$ 


\section{Appendix 17. \\ Concentration versus Time Data for Tests at 4.5 $\mathrm{M} \mathrm{Na}^{+}, 0.2 \mathrm{~g} / \mathrm{L} \mathrm{MST}$, High Activity Solution (Bottles \# 11 and 31) \\ (Units of Time $=$ hours; Units of Concentration $=\mu \mathrm{g} / \mathrm{L}$ )}

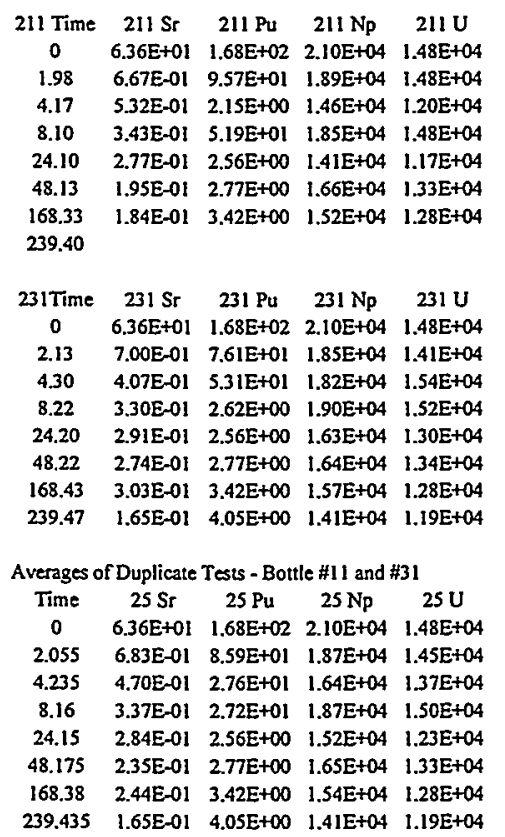

41

$\begin{array}{ccccc}611 T i m e & 611 \mathrm{Sr} & 611 \mathrm{Pu} & 611 \mathrm{~Np} & 611 \mathrm{U} \\ 0 & 6.04 \mathrm{E}+01 & 1.60 \mathrm{E}+02 & 2.16 \mathrm{E}+04 & 1.56 \mathrm{E}+04 \\ 2.15 & 6.24 \mathrm{E}-01 & 2.15 \mathrm{E}+00 & 1.75 \mathrm{E}+04 & 1.52 \mathrm{E}+04 \\ 4.13 & 5.71 \mathrm{E}-01 & 2.15 \mathrm{E}+00 & 1.58 \mathrm{E}+04 & 1.47 \mathrm{E}+04 \\ 8.18 & 5.71 \mathrm{E}-01 & 2.15 \mathrm{E}+00 & 1.21 \mathrm{E}+04 & 1.23 \mathrm{E}+04 \\ 24.03 & 5.69 \mathrm{E}-01 & 2.15 \mathrm{E}+00 & 1.01 \mathrm{E}+04 & 1.17 \mathrm{E}+04 \\ 48.03 & 5.00 \mathrm{E}-01 & 2.15 \mathrm{E}+00 & 9.13 \mathrm{E}+03 & 1.34 \mathrm{E}+04 \\ 96.00 & 4.90 \mathrm{E}-01 & 2.15 \mathrm{E}+00 & 8.87 \mathrm{E}+03 & 1.26 \mathrm{E}+04 \\ 167.82 & 5.52 \mathrm{E}-01 & 2.15 \mathrm{E}+00 & 7.17 \mathrm{E}+03 & 1.16 \mathrm{E}+04 \\ & & & & \\ 631 \mathrm{Time} & 631 \mathrm{Sr} & 631 \mathrm{Pu} & 631 \mathrm{~Np} & 631 \mathrm{U} \\ 0 & 6.04 \mathrm{E}+01 & 1.60 \mathrm{E}+02 & 2.16 \mathrm{E}+04 & 1.56 \mathrm{E}+04 \\ 2.32 & 7.14 \mathrm{E}-01 & 2.15 \mathrm{E}+00 & & \\ 4.27 & 5.14 \mathrm{E}-01 & 2.15 \mathrm{E}+00 & 1.65 \mathrm{E}+04 & 1.47 \mathrm{E}+04 \\ 7.37 & 5.51 \mathrm{E}-01 & 2.62 \mathrm{E}+00 & 1.33 \mathrm{E}+04 & 1.37 \mathrm{E}+04 \\ 24.17 & 4.29 \mathrm{E}-01 & 2.56 \mathrm{E}+00 & 9.58 \mathrm{E}+03 & 1.13 \mathrm{E}+04 \\ 48.28 & 5.30 \mathrm{E}-01 & 1.68 \mathrm{E}+01 & 8.48 \mathrm{E}+03 & 1.27 \mathrm{E}+04 \\ 96.17 & 5.95 \mathrm{E}-01 & 3.42 \mathrm{E}+00 & 8.77 \mathrm{E}+03 & 1.28 \mathrm{E}+04 \\ 167.93 & 4.62 \mathrm{E}-01 & 4.05 \mathrm{E}+00 & 7.09 \mathrm{E}+03 & 1.13 \mathrm{E}+04\end{array}$

45 Time $\quad 45 \mathrm{Sr} \quad 45 \mathrm{Pu} \quad 45 \mathrm{~Np} \quad 45 \mathrm{U}$ $\begin{array}{lllll}0 & 5.42 \mathrm{E}+01 & 1.61 \mathrm{E}+02 & 2.10 \mathrm{E}+04 & 1.50 \mathrm{E}+04\end{array}$ $2.525 \quad 4.94 \mathrm{E}-01 \quad 2.15 \mathrm{E}+00 \quad 1.50 \mathrm{E}+04 \quad 1.28 \mathrm{E}+04$ 4.515 4.66E-01 2.15E+00 1.55E +04 1.28E+04 $8.49 \quad 3.91 \mathrm{E}-01 \quad 2.15 \mathrm{E}+00 \quad 1.54 \mathrm{E}+04 \quad 1.31 \mathrm{E}+04$ $\begin{array}{llllll}24.615 & 3.20 \mathrm{E}-01 & 2.15 \mathrm{E}+00 & 1.81 \mathrm{E}+04 & 1.58 \mathrm{E}+04\end{array}$ $48.465 \quad 3.11 \mathrm{E}-01 \quad 2.15 \mathrm{E}+00 \quad 1.39 \mathrm{E}+04 \quad 1.31 \mathrm{E}+04$ $95.965 \quad 2.70 \mathrm{E}-01 \quad 2.15 \mathrm{E}+00 \quad 1.39 \mathrm{E}+04 \quad 1.38 \mathrm{E}+04$

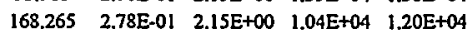

65 Time $65 \mathrm{Sr} \quad 65 \mathrm{Pu} \quad 65 \mathrm{~Np} \quad 65 \mathrm{U}$ $\begin{array}{ccccc}0 & 6.04 \mathrm{E}+01 & 1.60 \mathrm{E}+02 & 2.16 \mathrm{E}+04 & 1.56 \mathrm{E}+04\end{array}$ $2.235 \quad 6.69 \mathrm{E}-01 \quad 2.15 \mathrm{E}+00 \quad 1.75 \mathrm{E}+04 \quad 1.52 \mathrm{E}+04$ $\begin{array}{lllll}4.2 & 5.43 \mathrm{E}-01 & 2.15 \mathrm{E}+00 & 1.62 \mathrm{E}+04 & 1.47 \mathrm{E}+04\end{array}$ $\begin{array}{lllll}7.775 & 5.61 \mathrm{E}-01 & 2.38 \mathrm{E}+00 & 1.27 \mathrm{E}+04 & 1.30 \mathrm{E}+04\end{array}$ $24.1 \quad 4.99 \mathrm{E}-01 \quad 2.35 \mathrm{E}+00 \quad 9.86 \mathrm{E}+03 \quad 1.15 \mathrm{E}+04$ $\begin{array}{llllll}96.085 & 5.42 \mathrm{E}-01 & 2.78 \mathrm{E}+00 & 8.82 \mathrm{E}+03 & 1.27 \mathrm{E}+04\end{array}$

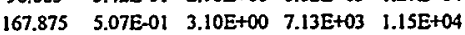
$\begin{array}{llllll}48.155 & 5.15 \mathrm{E}-01 \quad 9.50 \mathrm{E}+00 \quad 8.80 \mathrm{E}+03 \quad 1.30 \mathrm{E}+04\end{array}$ 


\section{Appendix 18.}

Concentration versus Time Data for Tests at

4.5 $\mathrm{M} \mathrm{Na}^{+}, 2.0 \mathrm{~g} / \mathrm{L} \mathrm{MST}$, High Activity Solution

(Bottles \# 20 and 29)

(Units of Time $=$ hours; Units of Concentration $=\mu \mathrm{g} / \mathrm{L}$ )

\begin{tabular}{|c|c|c|c|c|}
\hline 220 Time & $220 \mathrm{Sr}$ & $220 \mathrm{Pu}$ & $220 \mathrm{~Np}$ & $220 \mathrm{U}$ \\
\hline 0 & $6.36 \mathrm{E}+0 \mathrm{I}$ & $1.68 \mathrm{E}+02$ & 2.10E+04 & $1.48 \mathrm{E}+04$ \\
\hline 2.03 & $1.84 \mathrm{E}-03$ & $2.15 E+00$ & $1.50 E+04$ & $9,65 \mathrm{E}+03$ \\
\hline 4.23 & 2,87E-03 & $1.94 \mathrm{E}+0 \mathrm{l}$ & $1.47 E+04$ & $8.32 E+03$ \\
\hline 8.17 & 2.91E-03 & $2.62 E+00$ & $1.53 E+04$ & $7.83 E+03$ \\
\hline 24.15 & 2.78E-03 & $2.56 \mathrm{E}+00$ & $1.23 E+04$ & $5.33 E+03$ \\
\hline 48.17 & $.15 E-02$ & 2.77E +00 & $1.24 E+04$ & $4.14 E+03$ \\
\hline 168.38 & $15 \mathrm{E}-03$ & $3.42 \mathrm{E}+00$ & $1.03 E+04$ & $2.29 \mathrm{E}+03$ \\
\hline 239.43 & $3.38 \mathrm{E}-03$ & $4.05 E+00$ & $9.31 E+03$ & $1.91 E+03$ \\
\hline $229 \mathrm{TI}$ & $229 \mathrm{Sr}$ & & & \\
\hline 0 & $6.36 \mathrm{E}+01$ & $1.68 \mathrm{E}+02$ & 2.10E+04 & $1,48 E+04$ \\
\hline 2.12 & 1E-02 & $2.15 \mathrm{E}+00$ & 1.53 & $1,00 E+04$ \\
\hline 4.28 & OE-03 & $1.92 \mathrm{E}+01$ & $1,80 \mathrm{E}+04$ & $1.00 E+04$ \\
\hline 8.20 & 1E-03 & $2.62 \mathrm{E}+00$ & 1.55E+04 & $7.98 \mathrm{E}+03$ \\
\hline 24.18 & 29E-03 & $2.56 \mathrm{E}+00$ & $1.25 E+04$ & $5.61 E+03$ \\
\hline 48.20 & $.95 \mathrm{E}-03$ & $2.77 \mathrm{E}+00$ & $1.21 \mathrm{E}+04$ & $4.34 E+03$ \\
\hline 168.4 & 15E-03 & $3.42 \mathrm{E}+00$ & $1.04 E+04$ & $2.45 E+03$ \\
\hline $239.4 ?$ & BE- 03 & $4.05 \mathrm{E}+00$ & $8.96 \mathrm{E}+03$ & $1.87 E+03$ \\
\hline \multicolumn{5}{|c|}{ verages of Duplicate Tests - Bottle $\$ 20$ and $\$ 29$} \\
\hline $\begin{array}{c}\text { Time } \\
0\end{array}$ & $\begin{array}{c}25 \mathrm{Sr} \\
6.36 \mathrm{E}+01\end{array}$ & $\begin{array}{c}25 \mathrm{Pu} \\
1.68 \mathrm{E}+02\end{array}$ & $\begin{array}{c}25 \mathrm{~Np} \\
2.10 \mathrm{E}+04\end{array}$ & $\begin{array}{c}25 \mathrm{U} \\
1.48 \mathrm{E}+04\end{array}$ \\
\hline 2.075 & $2.84 \mathrm{E}-02$ & $2.15 E+00$ & $1.52 E+04$ & $9,83 E+03$ \\
\hline & $2.89 \mathrm{E}-03$ & $1.93 \mathrm{E}+0 \mathrm{I}$ & 1.63E+04 & $9.17 E+03$ \\
\hline & $91 \mathrm{E}-03$ & $2.62 E+00$ & 1.54E+04 & 7.91E+03 \\
\hline & $3.04 \mathrm{E}-03$ & $2.56 \mathrm{E}+00$ & $1.24 \mathrm{E}+04$ & $5.47 E+03$ \\
\hline & & $2.77 \mathrm{E}+00$ & $1.22 E+04$ & $4.24 E+03$ \\
\hline & & $3.42 \mathrm{E}+00$ & $1.04 \mathrm{E}+04$ & $2.37 E+03$ \\
\hline 39.45 & & $4.05 E+00$ & $9.14 E+03$ & $1.89 E+03$ \\
\hline
\end{tabular}

420 Time $420 \mathrm{Sr} \quad 420 \mathrm{Pu} \quad 420 \mathrm{~Np} \quad 420 \mathrm{U}$ $\begin{array}{ccccc}0 & 5.42 \mathrm{E}+01 & 1.61 \mathrm{E}+02 & 2.10 \mathrm{E}+04 & 1.50 \mathrm{E}+04\end{array}$ $\begin{array}{llllll}2.47 & 3.19 \mathrm{E}-03 & 2.15 \mathrm{E}+00 & 1.23 \mathrm{E}+04 & 6.88 \mathrm{E}+03\end{array}$ $\begin{array}{llllll}4.47 & 3.06 E-03 & 2.15 E+00 & 1.14 E+04 & 5.39 E+03\end{array}$ $\begin{array}{lllll}8.45 & 5.30 \mathrm{E}-02 & 2.15 \mathrm{E}+00 & 1.16 \mathrm{E}+04 & 4.60 \mathrm{E}+03\end{array}$ $24.58 \quad 3.18 \mathrm{E}-03 \quad 2.15 \mathrm{E}+00 \quad 1.18 \mathrm{E}+04 \quad 2.96 \mathrm{E}+03$ $\begin{array}{llllll}48.43 \quad 3.23 E-03 & 2.15 E+00 & 8.10 E+03 & 1.76 E+03\end{array}$ $95.93 \quad 3.25 E-03 \quad 2.15 E+00 \quad 735 E+03 \quad 1.64 E+03$ $\begin{array}{lllll}168.23 & 3.15 \mathrm{E}-02 & 2.15 E+00 & 4.37 \mathrm{E}+03 & 1.19 \mathrm{E}+03\end{array}$

$429 \mathrm{Time} \quad 429 \mathrm{Sr} \quad 429 \mathrm{Pu} \quad 429 \mathrm{~Np} \quad 429 \mathrm{U}$ $\begin{array}{lllll}0 & 5.42 E+01 & 1.61 E+02 & 2.10 E+04 & 1.50 E+04\end{array}$ $\begin{array}{lllll}2.70 & 3.21 \mathrm{E}-03 & 2.15 \mathrm{E}+00 & 1.19 \mathrm{E}+04 & 7.10 \mathrm{E}+03\end{array}$ $\begin{array}{lllll}4.70 & 2.85 \mathrm{E}-03 & 2.15 \mathrm{E}+00 & 1.21 \mathrm{E}+04 & 5.70 \mathrm{E}+03\end{array}$ $8.68 \quad 5.72 E-02 \quad 2.15 E+00 \quad 1.15 E+04 \quad 4.79 E+03$ $24.80 \quad 3.18 E-03 \quad 2.15 E+00 \quad 1.24 E+04 \quad 3.29 E+03$ $\begin{array}{llllll}48.63 & 4.47 \mathrm{E}-02 & 2.15 \mathrm{E}+00 & 8.24 \mathrm{E}+03 & 1.91 \mathrm{E}+03\end{array}$ $96.15 \quad 3.25 \mathrm{E}-03 \quad 2.15 \mathrm{E}+00 \quad 8.01 \mathrm{E}+03 \quad 1.88 \mathrm{E}+03$

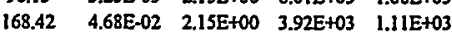

45 Time $\quad 45 \mathrm{Sr} \quad 45 \mathrm{Pu} \quad 45 \mathrm{~Np} \quad 45 \mathrm{U}$ $\begin{array}{lcccc}0 & 5.42 \mathrm{E}+01 & 1.61 \mathrm{E}+02 & 2.10 \mathrm{E}+04 & 1.50 \mathrm{E}+04\end{array}$ $\begin{array}{llllll}2.585 & 3.20 \mathrm{E}-03 & 2.15 \mathrm{E}+00 & 1.21 \mathrm{E}+04 & 6.99 \mathrm{E}+03\end{array}$ $4.585 \quad 2.95 E-03 \quad 2.15 E+00 \quad 1.17 E+04 \quad 5.55 E+03$ $8.565 \quad 5.51 E-02 \quad 2.15 E+00 \quad 1.15 E+04 \quad 4.70 E+03$ $24.69 \quad 3.18 \mathrm{E}-03 \quad 2.15 \mathrm{E}+00 \quad 1.21 \mathrm{E}+04 \quad 3.13 \mathrm{E}+03$ 48.53 2.39E-02 2.15E+00 8.17E+03 $1.83 \mathrm{E}+03$ $\begin{array}{lllll}96.04 & 3.25 E-03 & 2.15 E+00 & 7.68 E+03 & 1.76 E+03\end{array}$ $168.325 \quad 3.92 E-02 \quad 2.15 E+00 \quad 4.15 E+03 \quad 1.15 E+03$

$\begin{array}{ccccc}620 \text { Time } & 620 \mathrm{Sr} & 620 \mathrm{Pu} & 620 \mathrm{~Np} & 620 \mathrm{U} \\ 0 & 6.04 \mathrm{E}+01 & 1.60 \mathrm{E}+02 & 2.16 \mathrm{E}+04 & 1.56 \mathrm{E}+04 \\ 2.27 & 6.77 \mathrm{E}-03 & 2.15 \mathrm{E}+00 & 1.04 \mathrm{E}+04 & 5.89 \mathrm{E}+03 \\ 4.25 & 3.16 \mathrm{E}-03 & 2.15 \mathrm{E}+00 & 1.07 \mathrm{E}+04 & 4.45 \mathrm{E}+03 \\ 8.32 & 8.40 \mathrm{E}-03 & 2.15 \mathrm{E}+00 & 8.31 \mathrm{E}+03 & 3.15 \mathrm{E}+03 \\ 24.12 & 4.15 \mathrm{E}-02 & 2.15 \mathrm{E}+00 & 4.43 \mathrm{E}+03 & 2.07 \mathrm{E}+03 \\ 48.20 & 7.10 \mathrm{E}-02 & 2.15 \mathrm{E}+00 & 9.56 \mathrm{E}+02 & 1.86 \mathrm{E}+03 \\ 96.10 & 5.59 \mathrm{E}-02 & 2.15 \mathrm{E}+00 & 3.17 \mathrm{E}+02 & 1.72 \mathrm{E}+03 \\ 167.93 & 3.35 \mathrm{E}-03 & 2.15 \mathrm{E}+00 & 2.89 \mathrm{E}+02 & 1.73 \mathrm{E}+03 \\ & & & & \\ 629 \mathrm{Time} & 629 \mathrm{Sr} & 629 \mathrm{Pu} & 629 \mathrm{~Np} & 629 \mathrm{U} \\ 0 & 6.04 \mathrm{E}+01 & 1.60 \mathrm{E}+02 & 2.16 \mathrm{E}+04 & 1.56 \mathrm{E}+04 \\ 2.32 & 4.52 \mathrm{E}-03 & 2.15 \mathrm{E}+00 & 1.06 \mathrm{E}+04 & 6.06 \mathrm{E}+03 \\ 4.27 & 9.36 \mathrm{E}-04 & 2.15 \mathrm{E}+00 & 1.06 \mathrm{E}+04 & 4.41 \mathrm{E}+03 \\ 7.38 & 3.35 \mathrm{E}-02 & 2.15 \mathrm{E}+00 & 8.52 \mathrm{E}+03 & 3.29 \mathrm{E}+03 \\ 24.17 & 9.37 \mathrm{E}-02 & 2.15 \mathrm{E}+00 & 4.54 \mathrm{E}+03 & 1.96 \mathrm{E}+03 \\ 48.27 & 4.80 \mathrm{E}-03 & 2.15 \mathrm{E}+00 & 9.74 \mathrm{E}+02 & 1.96 \mathrm{E}+03 \\ 96.17 & 5.43 \mathrm{E}-02 & 2.15 \mathrm{E}+00 & 3.06 \mathrm{E}+02 & 1.77 \mathrm{E}+03 \\ 167.95 & 3.35 \mathrm{E}-03 & 2.15 \mathrm{E}+00 & 2.34 \mathrm{E}+02 & 1.41 \mathrm{E}+03\end{array}$

$65 \mathrm{Time} \quad 65 \mathrm{Sr} \quad 65 \mathrm{Pu} \quad 65 \mathrm{~Np} \quad 65 \mathrm{U}$ $\begin{array}{llllll}0 & 60.4 & 1.60 \mathrm{E}+02 & 2.16 \mathrm{E}+04 & 1.56 \mathrm{E}+04\end{array}$ $\begin{array}{cccccc}2.295 & 0.0056417 & 2.15 E+00 & 1.05 E+04 & 5.98 E+03\end{array}$ $4.26 \quad 0.0020466 \quad 2.15 E+00 \quad 1.07 E+04 \quad 4.43 E+03$ $\begin{array}{llllll}7.85 & 0.020954 & 2.15 E+00 & 8.42 E+03 & 3.22 E+03\end{array}$ $24.145 \quad 0.0676066 \quad 2.15 E+00 \quad 4.49 E+03 \quad 2.01 E+03$ $\begin{array}{llllll}48.235 & 0.0378849 & 2.15 E+00 & 9.65 E+02 & 1.91 E+03\end{array}$ $\begin{array}{llllll}96.135 & 0.0551141 & 2.15 E+00 & 3.12 E+02 & 1.74 E+03\end{array}$ $167.94 \quad 0.0033484 \quad 2.15 E+00 \quad 2.61 E+02 \quad 1.57 E+03$ 


\section{Appendix 19.}

Concentration versus Time Data for Tests at 6.0 $\mathrm{M} \mathrm{Na}^{+}, 1.1 \mathrm{~g} / \mathrm{L}$ MST, High Activity Solution (Bottles \# 07 and 32)

(Units of Time $=$ hours; Units of Concentration $=\mu \mathrm{g} / \mathrm{L}$ )

\begin{tabular}{|c|c|c|c|c|}
\hline 207 Time & $207 \mathrm{Sr}$ & $207 \mathrm{Pu}$ & $207 \mathrm{~Np}$ & $207 \mathrm{U}$ \\
\hline 0 & $8.48 \mathrm{E}+01$ & $2.23 E+02$ & $2.80 E+04$ & $1.97 \mathrm{E}+04$ \\
\hline 1.97 & $1.06 \mathrm{E}-01$ & $8.03 E+01$ & $2.29 \mathrm{E}+04$ & $1.67 E+04$ \\
\hline 4.15 & $3.10 E-02$ & $2.15 E+\infty$ & $1.80 E+04$ & $1.36 E+04$ \\
\hline 8.08 & $681 \mathrm{E}-02$ & $4.38 \mathrm{E}+01$ & 2.10E+04 & $1.54 E+04$ \\
\hline 24.08 & & 3.4IE+0I & $1.88 \mathrm{E}+04$ & $1.21 \mathrm{E}+04$ \\
\hline 48.12 & $1.35 \mathrm{E}-02$ & $2.44 E+01$ & $1.93 E+04$ & $1.11 E+04$ \\
\hline 16832 & $4.03 \mathrm{E}-02$ & 2.15E +00 & $1.74 \mathrm{E}+04$ & $8.31 \mathrm{E}+03$ \\
\hline 239.38 & $581 E-02$ & $2.15 E+00$ & $1.59 \mathrm{E}+04$ & $7.18 \mathrm{E}+03$ \\
\hline 232 Time & $232 \mathrm{Sr}$ & $232 \mathrm{Pu}$ & $232 \mathrm{~Np}$ & $232 \mathrm{U}$ \\
\hline 0 & $8.48 \mathrm{E}+01$ & $2.23 \mathrm{E}+02$ & $2.80 E+04$ & $1.97 \mathrm{E}+04$ \\
\hline 2.15 & $8.03 E-02$ & $4.84 \mathrm{E}+01$ & $2.17 E+04$ & $1.67 E+04$ \\
\hline 4.32 & $8.47 \mathrm{E}-02$ & $4.15 \mathrm{E}+01$ & $2.26 E+04$ & $1.59 \mathrm{E}+0.4$ \\
\hline 8.23 & $1.72 \mathrm{E}-01$ & $3.56 \mathrm{E}+01$ & $2.28 E+04$ & $1.64 E+04$ \\
\hline 24.20 & $1.31 E-01$ & $2.15 E+00$ & $3.89 E+04$ & $1.20 \mathrm{E}+04$ \\
\hline 48.23 & $3.84 \mathrm{E}-03$ & 2. $15 E+00$ & $1.95 \mathrm{E}+04$ & $1.09 E+04$ \\
\hline 168.45 & $3.94 \mathrm{E}-02$ & $2.15 \mathrm{E}+00$ & $1.81 \mathrm{E}+04$ & $8.41 E+03$ \\
\hline \multicolumn{5}{|l|}{239.48} \\
\hline \multicolumn{5}{|c|}{ Averages of Duplicate Tests - Bottle $\# 7$ and $\# 32$} \\
\hline Time & $25 \mathrm{Sr}$ & $25 \mathrm{Pu}$ & $25 \mathrm{~Np}$ & $25 \mathrm{U}$ \\
\hline 0 & $8.48 E+01$ & $2.23 \mathrm{E}+02$ & $2.80 \mathrm{E}+04$ & $1.97 \mathrm{E}+04$ \\
\hline 2.06 & $9.34 \mathrm{E}-02$ & $6.44 \mathrm{E}+01$ & 2.23E+04 & $1.67 E+04$ \\
\hline 4.235 & $5.79 E-02$ & $2.18 \mathrm{E}+01$ & $2.03 E+04$ & $1.48 \mathrm{E}+04$ \\
\hline 8.155 & $1.20 \mathrm{E}-01$ & $3.97 E+01$ & $2.19 \mathrm{E}+04$ & $1.59 \mathrm{E}+04$ \\
\hline 24.14 & $1.31 \mathrm{E}-01$ & $1.81 \mathrm{E}+01$ & $1.88 \mathrm{E}+04$ & $1.21 E+04$ \\
\hline 48.175 & $8.68 \mathrm{E}-03$ & $1.33 \mathrm{E}+01$ & $1.94 \mathrm{E}+04$ & $1.10 \mathrm{E}+04$ \\
\hline 168.385 & $3.98 \mathrm{E}-02$ & $2.15 E+00$ & $1.78 \mathrm{E}+04$ & $8.36 E+03$ \\
\hline 239.43 & $5.81 \mathrm{E}-02$ & $2.15 E+00$ & $1.59 \mathrm{E}+04$ & 7.18E+03 \\
\hline
\end{tabular}

$407 \mathrm{Time} \quad 407 \mathrm{Sr} \quad 407 \mathrm{Pr} \quad 407 \mathrm{~Np} \quad 407 \mathrm{U}$ $\begin{array}{lllll}0 & 7.22 \mathrm{E}+01 & 2.14 \mathrm{E}+02 & 2.78 \mathrm{E}+04 & 2.00 \mathrm{E}+04\end{array}$ $\begin{array}{lllll}2.15 & 1.47 \mathrm{E}-02 & 2.15 \mathrm{E}+00 & 1.78 \mathrm{E}+04 & 1.40 \mathrm{E}+04\end{array}$ $4.17 \quad 7.52 \mathrm{E}-02 \quad 2.15 \mathrm{E}+00 \quad 1.78 \mathrm{E}+04 \quad 1.23 \mathrm{E}+04$ $8.15 \quad 3.19 \mathrm{E}-02 \quad 2.15 \mathrm{E}+00 \quad 1.48 \mathrm{E}+04 \quad 9.01 \mathrm{E}+03$ $\begin{array}{llllll}8.15 & 3.19 E-02 & 2.15 \mathrm{E}+00 & 1.48 \mathrm{E}+04 & 9.01 \mathrm{E}+03 \\ 24.28 & 7.51 \mathrm{E}-02 & 2.15 \mathrm{E}+00 & 1.85 \mathrm{E}+04 & 9.82 \mathrm{E}+03\end{array}$ $\begin{array}{lllll}24.28 & 7.51 \mathrm{E}-02 & 2.15 \mathrm{E}+00 & 1.85 \mathrm{E}+04 & 9.82 \mathrm{E}+03 \\ 48.17 & 3.68 \mathrm{E}-02 & 2.15 \mathrm{E}+00 & 1.66 \mathrm{E}+03 & 8.89 \mathrm{E}+03\end{array}$ $\begin{array}{lllll}95.60 & 4.16 \mathrm{E}-02 & 2.15 \mathrm{E}+00 & 1.18 \mathrm{E}+04 & 6.72 \mathrm{E}+03\end{array}$ $167.97 \quad 3.49 \mathrm{E}-02 \quad 2.15 \mathrm{E}+00 \quad 9.71 \mathrm{E}+03 \quad 7.15 \mathrm{E}+03$

432 Time $\quad 432 \mathrm{Sr} \quad 432 \mathrm{Pu} \quad 432 \mathrm{~Np} \quad 432 \mathrm{U}$ $\begin{array}{lllll}0 & 7.22 \mathrm{E}+01 & 2.14 \mathrm{E}+02 & 2.78 \mathrm{E}+04 & 2.00 \mathrm{E}+04\end{array}$ $\begin{array}{lllll}2.78 & 7.79 \mathrm{E}-02 & 2.15 \mathrm{E}+00 & 1.79 \mathrm{E}+04 & 1.29 \mathrm{E}+04\end{array}$ $\begin{array}{lllll}4.77 & 6.39 \mathrm{E}-02 & 2.15 \mathrm{E}+00 & 1.74 \mathrm{E}+04 & 1.16 \mathrm{E}+04\end{array}$ $8.75 \quad 5.96 \mathrm{E}-02 \quad 2.15 \mathrm{E}+00 \quad 1.83 \mathrm{E}+04 \quad 1.15 \mathrm{E}+04$ $\begin{array}{lllll}24.88 & 4.15 E-02 & 2.15 E+00 & 2.03 E+04 & 1.03 E+04\end{array}$ $48.72 \quad 5.26 \mathrm{E}-02 \quad 2.15 \mathrm{E} \div 00 \quad 1.53 \mathrm{E}+04 \quad 7.27 \mathrm{E}+03$ $96.22 \quad 2.95 \mathrm{E}-02 \quad 2.15 \mathrm{E}+00 \quad 1.60 \mathrm{E}+04 \quad 8.27 \mathrm{E}+03$ $\begin{array}{lllll}168.50 & 2.96 \mathrm{E}-02 & 2.15 \mathrm{E}+00 & 1.13 \mathrm{E}+04 & 6.47 \mathrm{E}+03\end{array}$

45 Time $45 \mathrm{Sr} \quad 45 \mathrm{Pu} \quad 45 \mathrm{~Np} \quad 45 \mathrm{U}$

$\begin{array}{lllll}0 & 7.22 \mathrm{E}+01 & 2.14 \mathrm{E}+02 & 2.78 \mathrm{E}+04 & 2.00 \mathrm{E}+04\end{array}$ $\begin{array}{lllll}2.465 & 4.63 \mathrm{E}-02 & 2.15 \mathrm{E}+00 & 1.78 \mathrm{E}+04 & 1.35 \mathrm{E}+04\end{array}$ $\begin{array}{ccccc}4.47 & 6.95 \mathrm{E}-02 & 2.15 \mathrm{E}+00 & 1.76 \mathrm{E}+04 & 1.19 \mathrm{E}+04\end{array}$ $\begin{array}{lllll}8.45 & 4.58 \mathrm{E}-02 & 2.15 \mathrm{E}+00 & 1.65 \mathrm{E}+04 & 1.02 \mathrm{E}+04\end{array}$ $\begin{array}{llllll}24.58 & 5.83 \mathrm{E}-02 & 2.15 \mathrm{E}+00 & 1.94 \mathrm{E}+04 & 1.00 \mathrm{E}+04\end{array}$ $\begin{array}{llllll}48.445 & 4.47 E-02 & 2.15 E+00 & 8.48 E+03 & 8.08 E+03\end{array}$ $95.91 \quad 3.56 \mathrm{E}-02 \quad 2.15 \mathrm{E}+00 \quad 1.39 \mathrm{E}+04 \quad 7.50 \mathrm{E}+03$

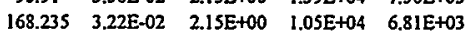

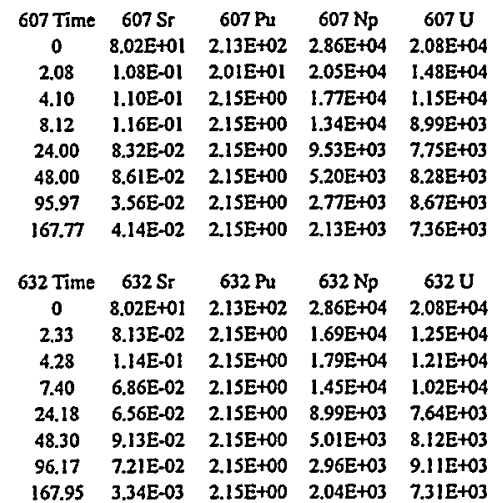

$65 \mathrm{Time} \quad 65 \mathrm{Sr} \quad 65 \mathrm{Pu} 65 \mathrm{~Np} 65 \mathrm{U}$ $\begin{array}{lllll}0 & 8.02 \mathrm{E}+01 & 2.13 \mathrm{E}+02 & 2.86 \mathrm{E}+04 & 2.08 \mathrm{E}+04\end{array}$ 2.205 9.45E-02 1.11E+01 1.87E+04 1.36E+04 $4.19 \quad 1.12 \mathrm{E}-01 \quad 2.15 \mathrm{E}+00 \quad 1.78 \mathrm{E}+04 \quad 1.18 \mathrm{E}+04$ $\begin{array}{lllll}7.76 & 9.21 \mathrm{E}-02 & 2.15 \mathrm{E}+00 & 1.39 \mathrm{E}+04 & 9.58 \mathrm{E}+03\end{array}$ $24.09 \quad 7.44 \mathrm{E}-02 \quad 2.15 \mathrm{E}+00 \quad 9.26 \mathrm{E}+03 \quad 7.70 \mathrm{E}+03$

$\begin{array}{llllll}48.15 & 8.87 \mathrm{E}-02 & 2.15 \mathrm{E}+00 & 5.10 \mathrm{E}+03 & 8.20 \mathrm{E}+03\end{array}$ $96.07 \quad 5.39 \mathrm{E}-02 \quad 2.15 \mathrm{E}+00 \quad 2.86 \mathrm{E}+03 \quad 8.89 \mathrm{E}+03$ $\begin{array}{ccccc}96.07 & 5.39 \mathrm{E}-02 & 2.1 \mathrm{EE}+00 & 2.86 \mathrm{E}+03 & 8.89 \mathrm{E}+03 \\ 167.86 & 2.24 \mathrm{E}-02 & 2.15 \mathrm{E}+00 & 2.08 \mathrm{E}+03 & 7.34 \mathrm{E}+03\end{array}$ 


\section{Appendix 20. \\ Concentration versus Time Data for Tests at 6.0 $\mathrm{M} \mathrm{Na}^{+}, 1.1 \mathrm{~g} / \mathrm{L} \mathrm{MST}$, High Activity Solution, No Mixing (Bottles \# 03 and 13) \\ (Units of Time $=$ hours; Units of Concentration $=\mu \mathrm{g} / \mathrm{L}$ )}

\begin{tabular}{|c|c|c|c|c|}
\hline 203 Time & $203 \mathrm{Sr}$ & $203 \mathrm{Pu}$ & $203 \mathrm{~Np}$ & $203 \mathrm{U}$ \\
\hline 0 & $8.48 \mathrm{E}+01$ & $2.23 E+02$ & $2.80 \mathrm{E}+04$ & $1.97 E+04$ \\
\hline 2.20 & $1.77 \mathrm{E}-0 \mathrm{I}$ & $4.48 \mathrm{E}+01$ & $2.28 E+04$ & $1.70 \mathrm{E}+04$ \\
\hline 4.28 & 2.93E-02 & $2.15 E+00$ & $1.87 \mathrm{E}+04$ & $1.40 E+04$ \\
\hline 8.27 & $4.77 \mathrm{E}-02$ & $2.15 E+00$ & $2.17 E+04$ & $1.51 E+04$ \\
\hline 24.22 & $1.11 \mathrm{E}-01$ & 2.15E+00 & $1.76 \mathrm{E}+04$ & 1.15E+04 \\
\hline 48.25 & $3.38 \mathrm{E}-02$ & $2.49 E+01$ & $1.98 \mathrm{E}+04$ & $1.19 E+04$ \\
\hline 168,48 & 1.8BE-01 & 2.15E+00 & $1.85 E+04$ & $9.20 E+03$ \\
\hline 239.55 & 9.15E-02 & 2.15E+00 & $1.73 E+04$ & $8.02 E+03$ \\
\hline 3 Time & $213 \mathrm{Sr}$ & 213 & $213 \mathrm{~Np}$ & $213 \mathrm{U}$ \\
\hline 0 & $8.48 \mathrm{E}+01$ & $2.23 E+02$ & $2.80 \mathrm{E}+04$ & $1.97 E+04$ \\
\hline 2.22 & $1.13 \mathrm{E}-01$ & 4.71E+0! & $2.22 \mathrm{E}+04$ & 1.63E+04 \\
\hline 4.23 & & $2.15 E+00$ & $1.76 \mathrm{E}+04$ & $1.30 \mathrm{E}+04$ \\
\hline 8.28 & $4.75 \mathrm{E}-02$ & 2.15E+00 & $234 \mathrm{E}+04$ & $1.57 E+04$ \\
\hline 24.23 & & $3.09 \mathrm{E}+01$ & $1.68 \mathrm{E}+04$ & 1.12E+04 \\
\hline 48.28 & $2.30 \mathrm{E}-02$ & $24 \mid E+01$ & $1.81 \mathrm{E}+04$ & $1.06 E+04$ \\
\hline 168.50 & $1.04 E-01$ & $2.15 E+00$ & $1.86 \mathrm{E}+04$ & $9.01 E+03$ \\
\hline 239.5 & & & & \\
\hline \multicolumn{5}{|c|}{ Averages of Duplicate Tests - Bottle $\# 3$ and $\# 13$} \\
\hline Time & $25 \mathrm{Sr}$ & $25 \mathrm{Pu}$ & $25 \mathrm{~Np}$ & $25 \mathrm{U}$ \\
\hline 0 & $8.48 \mathrm{E}+01$ & $2.23 E+02$ & $280 \mathrm{E}+04$ & $1.97 \mathrm{E}+04$ \\
\hline 2.21 & $1.45 \mathrm{E}-01$ & $4.60 \mathrm{E}+0 \mathrm{l}$ & $2.25 E+04$ & $1.66 \mathrm{E}+04$ \\
\hline 4.255 & 2.93E-02 & $2.15 E+00$ & 1.8IE+04 & 1.35E+04 \\
\hline 8.275 & 4.76E-02 & $2.15 E+00$ & $2.26 \mathrm{E}+04$ & $1.54 \mathrm{E}+04$ \\
\hline 24.225 & $1.11 \mathrm{E}-01$ & $1.65 \mathrm{E}+01$ & $1.72 E+04$ & $1.13 E+04$ \\
\hline 48.265 & 2.84E-02 & 2.45E+01 & $1.90 E+04$ & $1.12 \mathrm{E}+04$ \\
\hline 168.49 & $1.46 \mathrm{E}-01$ & $2.15 E+00$ & $1.85 E+04$ & $9.10 E+03$ \\
\hline 239.55 & $9.15 E-02$ & $2.15 E+00$ & 1.73E+04 & $8.02 E+03$ \\
\hline
\end{tabular}

$\begin{array}{ccccc}403 \mathrm{Time} & 403 \mathrm{Sr} & 403 \mathrm{Pu} & 403 \mathrm{~Np} & 403 \mathrm{U} \\ 0 & 7.22 \mathrm{E}+01 & 2.14 \mathrm{E}+02 & 27800 & 2.00 \mathrm{E}+04 \\ 2.82 & 1.04 \mathrm{E}-01 & 2.15 \mathrm{E}+00 & 19148.06 & 1.41 \mathrm{E}+04 \\ 4.80 & 4.95 \mathrm{E}-02 & 2.15 \mathrm{E}+00 & 19058.44 & 1.22 \mathrm{E}+04 \\ 8.80 & 8.38 \mathrm{E}-02 & 2.15 \mathrm{E}+00 & 18081.66 & 1.17 \mathrm{E}+04 \\ 24.97 & 1.38 \mathrm{E}-01 & 2.15 \mathrm{E}+00 & 18232.46 & 9.99 \mathrm{E}+03 \\ 48.77 & 1.16 \mathrm{E}-01 & 2.15 \mathrm{5}+00 & 16825.12 & 8.83 \mathrm{E}+03 \\ 96.28 & 1.03 \mathrm{E}-01 & 2.15 \mathrm{E}+00 & 13988.54 & 7.46 \mathrm{E}+03 \\ 168.58 & 5.95 \mathrm{E}-02 & 2.15 \mathrm{E}+00 & 11736.68 & 7.19 \mathrm{E}+03\end{array}$

413 Time $413 \mathrm{Sr} \quad 413 \mathrm{Pu} \quad 413 \mathrm{~Np} \quad 413 \mathrm{U}$

$\begin{array}{ccccc}0 & 7.22 \mathrm{E}+01 & 2.14 \mathrm{E}+02 & 2.78 \mathrm{E}+04 & 2.00 \mathrm{E}+04\end{array}$ $\begin{array}{lllll}2.85 & 1.21 \mathrm{E}-01 & 2.15 \mathrm{E}+00 & 1.75 \mathrm{E}+04 & 1.32 \mathrm{E}+04\end{array}$ $\begin{array}{lllll}4.83 & 7.14 E-02 & 2.15 E+00 & 1.80 E+04 & 1.17 E+04\end{array}$ $8.83 \quad 8.73 \mathrm{E}-02 \quad 2.15 \mathrm{E}+00 \quad 1.60 \mathrm{E}+04 \quad 1.05 \mathrm{E}+04$ $24.98 \quad 1.17 \mathrm{E}-01 \quad 2.15 \mathrm{E}+00 \quad 1.92 \mathrm{E}+04 \quad 1.09 \mathrm{E}+04$ $48.78 \cdot 1.03 \mathrm{E}-01 \quad 2.15 \mathrm{E} \div 00 \quad 1.50 \mathrm{E}+04 \quad 8.36 \mathrm{E}+03$ $96.32 \quad 6.31 E-02 \quad 2.15 E+00 \quad 1.44 E+04 \quad 8.03 E+03$ $168.60 \quad 6.25 \mathrm{E}-02 \quad 2.15 \mathrm{E}+00 \quad 1.11 \mathrm{E}+04 \quad 7.11 \mathrm{E}+03$

45 Time $\quad 45 \mathrm{Sr} \quad 45 \mathrm{Pu} \quad 45 \mathrm{~Np} \quad 45 \mathrm{U}$ $\begin{array}{lllll}0 & 7.22 \mathrm{E}+01 & 2.14 \mathrm{E}+02 & 2.78 \mathrm{E}+04 & 2.00 \mathrm{E}+04\end{array}$ $2.835 \quad 1.13 \mathrm{E}-01 \quad 2.15 \mathrm{E}+00 \quad 1.83 \mathrm{E}+04 \quad 1.36 \mathrm{E}+04$ $4.815 \quad 6.05 E-02 \quad 2.15 E+00 \quad 1.85 E+04 \quad 1.20 E+04$ $\begin{array}{lllll}4.815 & 6.05 E-02 & 2.15 E+00 & 1.85 E+04 & 1.20 E+04 \\ 8.815 & 8.55 E-02 & 2.15 E+00 & 1.71 E+04 & 1.11 E+04\end{array}$ $\begin{array}{ccccc}8.815 & 8.55 E-02 & 2.15 E+00 & 1.71 E+04 & 1.11 E+04 \\ 24.975 & 1.28 E-01 & 2.15 E+00 & 1.87 E+04 & 1.05 E+04\end{array}$ $\begin{array}{llllll}24.975 & 1.28 \mathrm{E}-01 & 2.15 \mathrm{E}+00 & 1.87 \mathrm{E}+04 & 1.05 \mathrm{E}+04 \\ 48.775 & 1.10 \mathrm{E}-01 & 2.15 \mathrm{E}+00 & 1.59 \mathrm{E}+04 & 8.60 \mathrm{E}+03\end{array}$ $963 \quad 831 \mathrm{E}-02 \quad 215 \mathrm{E}+00 \quad 1.42 \mathrm{E}+04 \quad 7.74 \mathrm{E}+03$ $168.59 \quad 6.10 E-02 \quad 2.15 E+00 \quad 1.14 E+04 \quad 7.15 E+03$

\begin{tabular}{|c|c|c|c|c|}
\hline $\begin{array}{c}603 \text { Time } \\
0\end{array}$ & $\begin{array}{c}603 \mathrm{Sr} \\
8.02 \mathrm{E}+01\end{array}$ & $\begin{array}{c}603 \mathrm{Pu} \\
2.13 \mathrm{E}+02\end{array}$ & $\begin{array}{c}603 \mathrm{~Np} \\
2.86 \mathrm{E}+04\end{array}$ & $\begin{array}{r}603 \mathrm{U} \\
2.08 \mathrm{E}+0\end{array}$ \\
\hline 2.05 & 209E-01 & $1.87 E+01$ & 210E+04 & (9- \\
\hline 4.00 & $6.84 \mathrm{E}-02$ & 15E +00 & $.72 E+04$ & 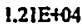 \\
\hline 8.02 & $1.268-01$ & $5 E+00$ & $34 \mathrm{E}+04$ & 45 \\
\hline 24.12 & $6.79 E-02$ & $15 E+00$ & $9.49 \mathrm{E}+03$ & 200 \\
\hline 48.05 & $7.58 E-02$ & $15 E+00$ & $5.24 E+03$ & 200 \\
\hline 95.98 & 7.08E-02 & $15 E+00$ & $.85 E+03$ & 120 \\
\hline 167.82 & 7.55E-02 & 2.15E+00 & $2.15 E+03$ & $68 \mathrm{~F}$ \\
\hline $\mathrm{Tim}$ & $3 \mathrm{Sr}$ & $613 \mathrm{Pu}$ & $613 \mathrm{~Np}$ & \\
\hline 0 & $8.02 E+01$ & $213 E+02$ & $286 \mathrm{E}+04$ & $208 \mathrm{E}+$ \\
\hline 2.07 & $1,00 E-01$ & 2.15E +00 & $1.92 E+04$ & I.42E+ \\
\hline 4.03 & 2.ITE-0I & 2.15E+00 & $1.71 E+04$ & I.19E+ \\
\hline 8.03 & $1.41 E-01$ & $15 E+00$ & $1.35 E+04$ & $9.29 \mathrm{E}+$ \\
\hline 24.12 & $1.50 \mathrm{E}-01$ & $2.15 \mathrm{E}+00$ & $9.48 \mathrm{E}+03$ & $7.77 \mathrm{E}+$ \\
\hline 48.07 & $1.03 E-01$ & $215 E+00$ & $5.74 E+03$ & $8.43 E+$ \\
\hline 95.98 & -02 & 00 & 295E+03 & 8.32E+ \\
\hline 167.83 & $6.78 \mathrm{E}-02$ & 2.15E +00 & $1.88 E+03$ & $7.55 \mathrm{E}+$ \\
\hline Time & & & $65 \mathrm{~N}$ & $65 \mathrm{U}$ \\
\hline 0 & $8.02 E+0 I$ & & $2.86 E+04$ & $2.08 \mathrm{E}+$ \\
\hline 206 & (5E-0) & $1.04 \mathrm{E}$ & 2.01E+04 & $1.47 E+1$ \\
\hline 4.015 & $1.43 \mathrm{E}-01$ & 2.15E+00 & $1.71 E+04$ & $1.20 \mathrm{E}+$ \\
\hline 8.025 & $1.33 \mathrm{E}-01$ & $2.15 E+00$ & $1.35 E+04$ & $9.37 E+C$ \\
\hline 24.12 & 99E-01 & 2.15E+00 & $9.49 \mathrm{E}+03$ & 7.99E+ \\
\hline 48.06 & $8.94 \mathrm{E}-02$ & $2.15 E+00$ & $5.49 \mathrm{E}+03$ & $8.32 E+C$ \\
\hline & & $2.15 E$ & $290 E+03$ & $8.22 E+$ \\
\hline 67.8 & & 00 & $.02 E+03$ & $7.6 \mathrm{IE}$ \\
\hline
\end{tabular}




\section{Appendix 21. \\ Concentration versus Time Data for Tests at \\ 6.0 $\mathrm{M} \mathrm{Na}^{+}, 1.1 \mathrm{~g} / \mathrm{L} \mathrm{MST}$, High Activity Solution, NaTPB or Sludge Added (Bottles \# 05 and 19) \\ (Units of Time $=$ hours; Units of Concentration $=\mu \mathrm{g} / \mathrm{L}$ )}

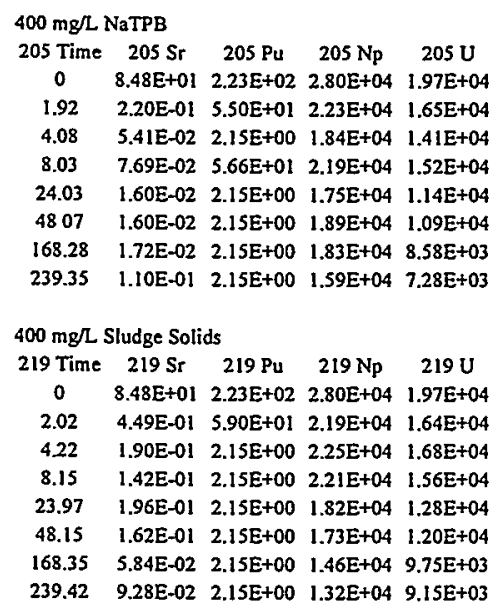

405 Time $405 \mathrm{Sr} \quad 405 \mathrm{Pu} \quad 405 \mathrm{~Np} \quad 405 \mathrm{U}$ $\begin{array}{lllll}0 & 7.22 \mathrm{E}+01 & 2.14 \mathrm{E}+02 & 27800 & 2.00 \mathrm{E}+04\end{array}$ $2.10 \quad 1.16 \mathrm{E}-01 \quad 2.15 \mathrm{E}+00 \quad 18602.38 \quad 1.44 \mathrm{E}+04$ $\begin{array}{llllll}4.10 & 4.91 \mathrm{E}-02 & 2.15 \mathrm{E}+00 & 17783.98 & 1.24 \mathrm{E}+04\end{array}$ $\begin{array}{lllll}8.10 & 1.04 \mathrm{E}-01 & 2.15 \mathrm{E}+00 & 16580.16 & 1.08 \mathrm{E}+04\end{array}$ $24.23 \quad 1.09 E-01 \quad 2.15 E+00 \quad 17901.56 \quad 9.51 E+03$ $\begin{array}{llllll}48.12 & 6.12 \mathrm{E}-02 & 2.15 \mathrm{E}+00 & 16847.3 & 9.05 \mathrm{E}+03\end{array}$ $\begin{array}{llllll}95.57 & 7.28 \mathrm{E}-02 & 2.15 \mathrm{E}+00 & 12107.96 & 7.21 \mathrm{E}+03\end{array}$ $\begin{array}{lllll}167.93 \quad 5.10 \mathrm{E}-02 & 2.15 \mathrm{E}+00 \quad 9570.76 \quad 7.23 \mathrm{E}+03\end{array}$

419 Time $419 \mathrm{Sr} \quad 419 \mathrm{Pu} \quad 419 \mathrm{~Np} \quad 419 \mathrm{U}$ $\begin{array}{lllll}0 & 7.22 \mathrm{E}+01 & 2.14 \mathrm{E}+02 & 2.78 \mathrm{E}+04 & 2.00 \mathrm{E}+04\end{array}$ $\begin{array}{lllll}2.43 & 2.05 \mathrm{E}-01 & 2.15 \mathrm{E}+00 & 1.79 \mathrm{E}+04 & 1.26 \mathrm{E}+04\end{array}$ $\begin{array}{lllll}4.43 \quad 1.30 \mathrm{E}-01 & 2.15 \mathrm{E}+00 \quad 1.74 \mathrm{E}+04 \quad 1.22 \mathrm{E}+04\end{array}$ $8.43 \quad 1.68 \mathrm{E}-01 \quad 2.15 \mathrm{E}+00 \quad 183 \mathrm{E}+04 \quad 1.20 \mathrm{E}+04$ $24.55 \quad 1.87 \mathrm{E}-01 \quad 2.15 \mathrm{E}+00 \quad 2.03 \mathrm{E}+04 \quad 1.17 \mathrm{E}+04$ 48.40 1.52E-01 2.15E+00 $1.53 \mathrm{E}+04 \quad 9.46 \mathrm{E}+03$ $95.92 \quad$ L.04E-01 $2.15 \mathrm{E}+00 \quad 1.60 \mathrm{E}+04 \quad 9.88 \mathrm{E}+03$ $\begin{array}{lllll}168.20 & 1.05 E-01 & 2.15 E+00 & 1.13 E+04 & 8.22 E+03\end{array}$

$\begin{array}{ccccc}605 \text { Time } & 605 \mathrm{Sr} & 605 \mathrm{Pu} & 605 \mathrm{~Np} & 605 \mathrm{U} \\ 0 & 8.02 \mathrm{E}+01 & 2.13 \mathrm{E}+02 & 2.86 \mathrm{E}+04 & 2.08 \mathrm{E}+04 \\ 2.05 & 2.09 \mathrm{E}-01 & 2.15 \mathrm{E}+00 & 2.09 \mathrm{E}+04 & 1.46 \mathrm{E}+04 \\ 4.05 & 1.29 \mathrm{E}-01 & 2.15 \mathrm{E}+00 & 1.73 \mathrm{E}+04 & 1.14 \mathrm{E}+04 \\ 8.10 & 8.87 \mathrm{E}-02 & 2.15 \mathrm{E}+00 & 1.36 \mathrm{E}+04 & 8.97 \mathrm{E}+03 \\ 23.97 & 1.76 \mathrm{E}-01 & 2.15 \mathrm{E}+00 & 9.34 \mathrm{E}+03 & 7.78 \mathrm{E}+03 \\ 47.97 & 1.19 \mathrm{E}-01 & 2.15 \mathrm{E}+00 & 4.96 \mathrm{E}+03 & 8.32 \mathrm{E}+03 \\ 65.93 & 9.43 \mathrm{E}-02 & 2.15 \mathrm{E}+00 & 2.72 \mathrm{E}+03 & 8.67 \mathrm{E}+03 \\ 167.67 & 9.54 \mathrm{E}-02 & 2.15 \mathrm{E}+00 & 2.09 \mathrm{E}+03 & 7.18 \mathrm{E}+03 \\ & & & & \\ & & & & \\ 619 \mathrm{Time} & 619 \mathrm{Sr} & 619 \mathrm{Pu} & 619 \mathrm{~Np} & 619 \mathrm{U} \\ 0 & 8.02 \mathrm{E}+01 & 2.13 \mathrm{E}+02 & 2.86 \mathrm{E}+04 & 2.08 \mathrm{E}+04 \\ 2.27 & 1.80 \mathrm{E}-01 & 2.15 \mathrm{E}+00 & 1.65 \mathrm{E}+04 & 1.31 \mathrm{E}+04 \\ 4.23 & 2.58 \mathrm{E}-01 & 2.15 \mathrm{E}+00 & 1.41 \mathrm{E}+04 & 1.20 \mathrm{E}+04 \\ 8.30 & 1.73 \mathrm{E}-01 & 2.15 \mathrm{E}+00 & 1.07 \mathrm{E}+04 & 1.06 \mathrm{E}+04 \\ 24.10 & 1.94 \mathrm{E}-01 & 2.15 \mathrm{E}+00 & 6.26 \mathrm{E}+03 & 9.02 \mathrm{E}+03 \\ 48.18 & 2.90 \mathrm{E}-03 & 6.32 \mathrm{E}+00 & 4.92 \mathrm{E}+03 & 9.69 \mathrm{E}+03 \\ 96.10 & 1.55 \mathrm{E}-01 & 2.15 \mathrm{E}+00 & 5.11 \mathrm{E}+03 & 1.00 \mathrm{E}+04 \\ 167.92 & 1.43 \mathrm{E}-01 & 2.15 \mathrm{E}+00 & 4.52 \mathrm{E}+03 & 8.89 \mathrm{E}+03\end{array}$




\section{Appendix 22. \\ Concentration versus Time Data for Tests at 7.5 $\mathrm{M} \mathrm{Na}^{+}, 0.2 \mathrm{~g} / \mathrm{L} \mathrm{MST}$, High Activity Solution (Bottles \# 01 and 28) \\ (Units of Time $=$ hours; Units of Concentration $=\mu \mathrm{g} / \mathrm{L}$ )}

\begin{tabular}{|c|c|c|c|c|}
\hline & & & & \\
\hline 0 & & & & $2018+0$ \\
\hline 1.88 & +00 & $45 E+02$ & $3.62 \mathrm{E}+04$ & $76 \mathrm{E}+04$ \\
\hline 4.02 & $88 E+\infty 0$ & $.05 E+02$ & $3.00 \mathrm{E}+04$ & $41 E+04$ \\
\hline 8.00 & 49E +00 & $.59 \mathrm{E}+02$ & $3.00 \mathrm{E}+04$ & \\
\hline 23.98 & $1.40 \mathrm{E}+00$ & $6.62 \mathrm{E}+01$ & $2.42 \mathrm{E}+04$ & $1.84 E+04$ \\
\hline 47.98 & $1,30 \mathrm{E}+\infty 0$ & $4.60 \mathrm{E}$ & $2.43 \mathrm{E}+04$ & $1.76 \mathrm{E}+04$ \\
\hline 168.25 & $1.17 E+00$ & & 2.27E+04 & $1.52 E+04$ \\
\hline 2 & $1.33 \mathrm{E}+\infty 0$ & $+\infty$ & $2.11 \mathrm{E}+04$ & 1.S1E+04 \\
\hline . & & & & 20 \\
\hline 0 & $1.06 \mathrm{E}+02$ & 2.801 & $E+04$ & $2.46 \mathrm{E}+04$ \\
\hline 2.10 & $2.21 E+\infty 0$ & $1.87 \mathrm{E}+02$ & E+04 & 2.12E+04 \\
\hline 4.27 & $1.86 \mathrm{E}$ & 1.93 & $E+04$ & $2.93 \mathrm{E}$ \\
\hline 8.20 & $1.58 \mathrm{E}+00$ & 1.35 & 3.02 & $2.34 \mathrm{E}+04$ \\
\hline 24.18 & 1.371 & 2.5 & 2.4 & $1.84 E+04$ \\
\hline & $1.22 \mathrm{E}+00$ & 5.21 & 2.3 & $1.65 \mathrm{E}+04$ \\
\hline 168.40 & $1.29 \mathrm{E}+00$ & 3.42 & $2.30 \mathrm{E}+04$ & $1.58 \mathrm{E}+04$ \\
\hline 8.58 & $1.34 E+\infty 0$ & $+\infty$ & $1.95 \mathrm{E}+04$ & $1.36 \mathrm{E}+04$ \\
\hline \multicolumn{5}{|c|}{ of Duplicate Tests - Bottle $\# 01$ and $\# 28$} \\
\hline Time & $25 \mathrm{Sr}$ & $25 \mathrm{Pu}$ & $25 \mathrm{~Np}$ & \\
\hline 0 & +02 & $2.80 \mathrm{~B}$ & $3.50 \mathrm{E}+04$ & $2.46 \mathrm{E}+04$ \\
\hline & $2.86 \mathrm{E}+00$ & $2.16 \mathrm{E}+02$ & $3.27 \mathrm{E}+04$ & $2.44 E+04$ \\
\hline 4.145 & $1.87 E+00$ & $1.99 \mathrm{E}$ & $3.39 \mathrm{E}+04$ & 2.67E+04 \\
\hline 8.1 & $1.54 \mathrm{E}+00$ & $1.47 \mathrm{E}$ & $3.01 E+04$ & $2.36 \mathrm{E}+04$ \\
\hline 24.08 & $1.38 E+00$ & 3.44 & $2.45 E+04$ & $1.84 E+04$ \\
\hline 3.09 & $1.26 \mathrm{~F}$ & 4.91 & $2.40 \mathrm{E}+04$ & I.7IE+04 \\
\hline 168.32 & 1.23 & 3.42 & $2.29 \mathrm{E}+04$ & $1.55 \mathrm{E}+04$ \\
\hline 238.955 & $133 \mathrm{E}+00$ & $4,05 \mathrm{E}+00$ & $2.03 \mathrm{E}+04$ & $1.43 \mathrm{E}+04$ \\
\hline
\end{tabular}

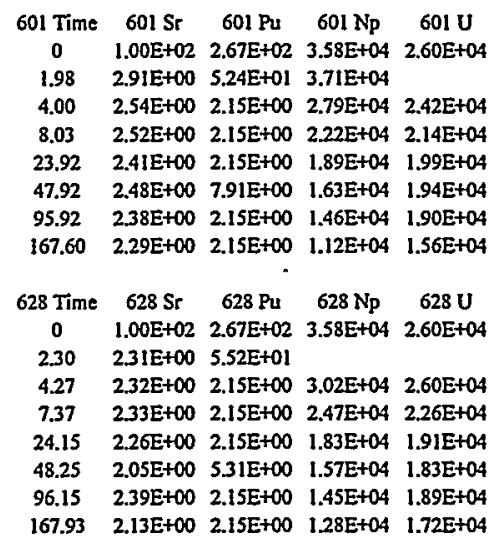

601 Time $601 \mathrm{Sr} \quad 601 \mathrm{Pu} \quad 601 \mathrm{~Np} \quad 601 \mathrm{U}$ $\begin{array}{lllll}0 & 1.00 \mathrm{E}+02 & 2.67 \mathrm{E}+02 & 3.58 \mathrm{E}+04 & 2.60 \mathrm{E}+04\end{array}$ $1.98 \quad 2.91 \mathrm{E}+00 \quad 5.24 \mathrm{E}+01 \quad 3.71 \mathrm{E}+04$

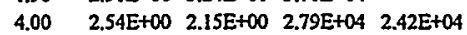

$\begin{array}{lllll}8.03 & 2.52 E+00 & 2.15 E+00 & 2.22 E+04 & 2.14 E+04\end{array}$

23.92 2.4IE+00 2.15E+00 1.89E+04 1.99E+04

$\begin{array}{llllll}47.92 & 2.48 \mathrm{E}+00 & 7.91 \mathrm{E}+00 & 1.63 \mathrm{E}+04 & 1.94 \mathrm{E}+04\end{array}$

$\begin{array}{lllll}95.92 & 2.38 \mathrm{E}+00 & 2.15 \mathrm{E}+00 & 1.46 \mathrm{E}+04 & 1.90 \mathrm{E}+04\end{array}$

$\begin{array}{lllll}167.60 & 2.29 \mathrm{E}+00 & 2.15 \mathrm{E}+00 & 1.12 \mathrm{E}+04 & 1.56 \mathrm{E}+04\end{array}$

$628 \mathrm{Time} \quad 628 \mathrm{Sr} \quad 628 \mathrm{Pu} \quad 628 \mathrm{~Np} \quad 628 \mathrm{U}$

$\begin{array}{lllll}0 & 1.00 \mathrm{E}+02 & 2.67 \mathrm{E}+02 & 3.58 \mathrm{E}+04 & 2.60 \mathrm{E}+04\end{array}$

$2.30 \quad 2.31 E+00 \quad 5.52 E+01$

$\begin{array}{lllll}4.27 & 2.32 E+\infty & 2.15 E+00 & 3.02 E+04 & 2.60 E+04\end{array}$

$\begin{array}{llllll}7.37 & 2.33 \mathrm{E}+00 & 2.15 \mathrm{E}+00 & 2.47 \mathrm{E}+04 & 2.26 \mathrm{E}+04\end{array}$

$24.15 \quad 2.26 \mathrm{E}+00 \quad 2.15 \mathrm{E}+00 \quad 1.83 \mathrm{E}+04 \quad 1.91 \mathrm{E}+04$

$\begin{array}{lllll}48.25 & 2.05 \mathrm{E}+00 \quad 5.31 \mathrm{E}+00 & 1.57 \mathrm{E}+04 & 1.83 \mathrm{E}+04\end{array}$

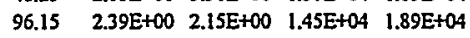

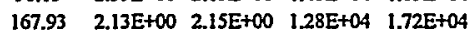

$428 \mathrm{Time} 428 \mathrm{Sr} 428 \mathrm{Pu} 428 \mathrm{NP} 428 \mathrm{U}$

$45 \mathrm{Time} \quad 45 \mathrm{Sr} \quad 45 \mathrm{Pu} \quad 45 \mathrm{~Np} \quad 45 \mathrm{U}$

$\begin{array}{llllllllllll}0 & 9.02 \mathrm{E}+01 & 2.69 \mathrm{E}+02 & 3.48 \mathrm{E}+04 & 2.50 \mathrm{E}+04\end{array}$

$\begin{array}{llllll}2.345 & 2.31 \mathrm{E}+00 & 1.06 \mathrm{E}+02 & 2.69 \mathrm{E}+04 & 2.42 \mathrm{E}+04\end{array}$

$\begin{array}{llllll}4.345 & 1.88 \mathrm{E}+00 & 2.15 \mathrm{E}+00 & 2.62 \mathrm{E}+04 & 2.13 \mathrm{E}+04\end{array}$

$\begin{array}{llllll}8.345 & 1.78 E+00 & 3.83 E+01 & 2.35 E+04 & 2.07 E+04\end{array}$

$24.45 \quad 1.55 E+00 \quad 2.15 E+00 \quad 2.56 E+04 \quad 2.23 E+04$

$48.32 \quad 1.15 \mathrm{E}+00 \quad 2.15 \mathrm{E}+00 \quad 2.12 \mathrm{E}+04 \quad 2.00 \mathrm{E}+04$

$\begin{array}{llllll}95.8 & 1.34 \mathrm{E}+00 & 2.15 \mathrm{E}+00 & 1.96 \mathrm{E}+04 & 1.92 \mathrm{E}+04\end{array}$

$\begin{array}{lllll}168.115 & 1.50 \mathrm{E}+00 & 2.15 \mathrm{E}+00 \quad 1.59 \mathrm{E}+04 & 1.63 \mathrm{E}+04\end{array}$ $\begin{array}{ccccc}65 \text { Time } & 65 \mathrm{Sr} & 65 \mathrm{Pu} & 65 \mathrm{~Np} & 65 \mathrm{U} \\ 0 & 1.00 \mathrm{E}+02 & 2.67 \mathrm{E}+02 & 3.58 \mathrm{E}+04 & 2.60 \mathrm{E}+04 \\ 2.14 & 2.61 \mathrm{E}+00 & 5.38 \mathrm{E}+01 & 3.71 \mathrm{E}+04 & \\ 4.135 & 2.43 \mathrm{E}+00 & 2.15 \mathrm{E}+00 & 2.91 \mathrm{E}+04 & 2.51 \mathrm{E}+04 \\ 7.7 & 2.43 \mathrm{E}+00 & 2.15 \mathrm{E}+00 & 2.34 \mathrm{E}+04 & 2.20 \mathrm{E}+04 \\ 24.035 & 2.34 \mathrm{E}+00 & 2.15 \mathrm{E}+00 & 1.86 \mathrm{E}+04 & 1.95 \mathrm{E}+04 \\ 48.085 & 2.26 \mathrm{E}+00 & 6.61 \mathrm{E}+00 & 1.60 \mathrm{E}+04 & 1.89 \mathrm{E}+04 \\ 96.035 & 2.39 \mathrm{E}+00 & 2.15 \mathrm{E}+00 & 1.45 \mathrm{E}+04 & 1.90 \mathrm{E}+04 \\ 167.765 & 2.21 \mathrm{E}+00 & 2.15 \mathrm{E}+00 & 1.20 \mathrm{E}+04 & 1.64 \mathrm{E}+04\end{array}$ 


\section{Appendix 23. \\ Concentration versus Time Data for Tests at 7.5M Na ${ }^{+}, 2.0 \mathrm{~g} / \mathrm{L}$ MST, High Activity Solution (Bottles \# 17 and 27) \\ (Units of Time $=$ hours; Units of Concentration $=\mu \mathrm{g} / \mathrm{L}$ )}

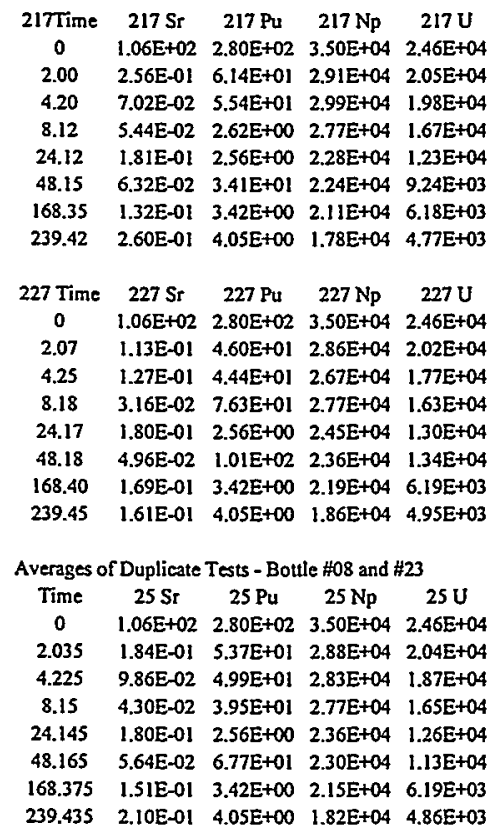

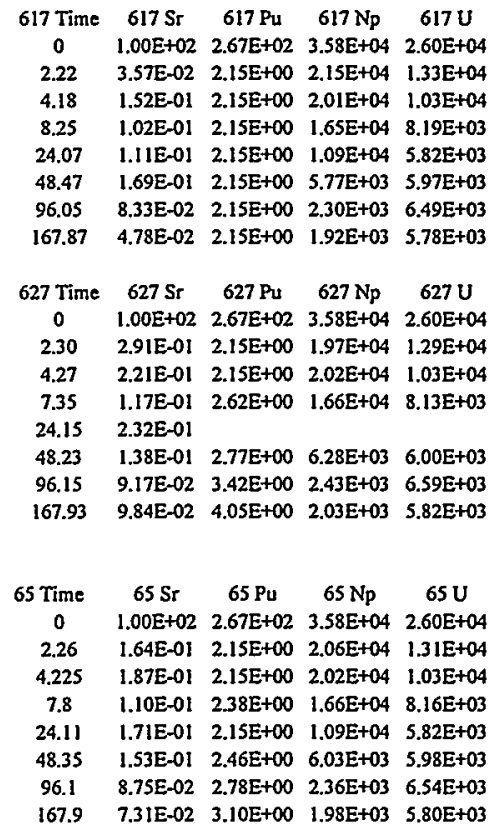




\section{Appendix 24. \\ Mole Ratios of Sorbates to MST

45
$6.0 \mathrm{M}$ \\ 45 \\ $4.5 \mathrm{M}$ \\ $65 \quad 65$ \\ $6.0 \mathrm{M} \quad 7.5 \mathrm{M}$}

$\begin{array}{ccc}\text { Temp (C) } & 25 & 25 \\ \text { [Na+] } & 4.5 \mathrm{M} & 6.0 \mathrm{M} \\ \text { High Activity } & {[\mathrm{MST}]=0.2 \mathrm{~g} / \mathrm{L}} \\ \text { Units } & \text { mole ratio } \\ \mathrm{Sr} & 7.23 \mathrm{E}-04 \\ \mathrm{Pu} & 7.03 \mathrm{E}-04 \\ \mathrm{~Np} & 8.86 \mathrm{E}-02 \\ \mathrm{U} & 6.22 \mathrm{E}-02 \\ \text { Total } & 1.52 \mathrm{E}-01\end{array}$

\begin{tabular}{cc}
25 & 45 \\
$7.5 \mathrm{M}$ & $4.5 \mathrm{M}$ \\
\multicolumn{2}{c}{ Mole ratios of } \\
mole ratio & mole ratio \\
$1.20 \mathrm{E}-03$ & $6.16 \mathrm{E}-04$ \\
$1.17 \mathrm{E}-03$ & $6.74 \mathrm{E}-04$ \\
$1.48 \mathrm{E}-01$ & $8.86 \mathrm{E}-02$ \\
$1.03 \mathrm{E}-01$ & $6.30 \mathrm{E}-02$ \\
$2.53 \mathrm{E}-01$ & $1.53 \mathrm{E}-01$
\end{tabular}

mole ratio mole ratio

mole ratio mole ratio

1.03E-03 6.86E-04

1.13E-03 6.69E-04

$1.47 \mathrm{E}-01 \quad 9.11 \mathrm{E}-02$

$1.05 \mathrm{E}-01 \quad 6.55 \mathrm{E}-02$

$2.54 \mathrm{E}-01 \quad 1.58 \mathrm{E}-01$

mole ratio

1.14E-03

$1.12 \mathrm{E}-03$

$1.51 \mathrm{E}-01$

1.09E-01

2.63E-01

Low Activity $[\mathrm{MST}]=0.2 \mathrm{~g} / \mathrm{L}$

$\begin{array}{cc}\text { Units } & \text { mole ratio } \\ \mathrm{Sr} & 5.64 \mathrm{E}-05 \\ \mathrm{Pu} & 4.69 \mathrm{E}-06 \\ \mathrm{~Np} & 1.43 \mathrm{E}-03 \\ \mathrm{U} & 6.39 \mathrm{E}-03 \\ \text { Total } & 7.88 \mathrm{E}-03\end{array}$

Mole ratios of $\mathrm{Sr}, \mathrm{Np}, \mathrm{Pu}$ and $\mathrm{U}$ to $\mathrm{MST}$

mole ratio mole ratio

mole ratio mole ratio

9.41E-05 5.66E-05

9.41E-05 5.66E-05

4.11E-05 7.28E-06

1.21E-05 2.34E-06

7.17E-03 2.48E-03

4.13E-03 1.49E-03

$1.08 \mathrm{E}-02 \quad 6.55 \mathrm{E}-03$

$1.09 \mathrm{E}-02 \quad 5.80 \mathrm{E}-03$

$1.81 \mathrm{E}-02 \quad 9.10 \mathrm{E}-03$

$1.52 \mathrm{E}-02 \quad 7.35 \mathrm{E}-03$

mole ratio

9.41E-05

$6.03 \mathrm{E}-06$

$2.49 \mathrm{E}-03$

$9.66 \mathrm{E}-03$

$1.23 \mathrm{E}-02$

High Activity $[\mathrm{MST}]=1.1 \mathrm{~g} / \mathrm{L}$

Units

$\mathrm{Sr} \quad 1.75 \mathrm{E}-04$

$\mathrm{Pu}$ 1.70E-04

$\mathrm{Np} \quad 2.15 \mathrm{E}-02$

$\mathrm{U} \quad 1.50 \mathrm{E}-02$

Total

3.69E-02

Low Activity $[\mathrm{MST}]=1.1 \mathrm{~g} / \mathrm{L}$

Units

mole ratio

$\mathrm{Sr} \quad 1.37 \mathrm{E}-05$

$\mathrm{Pu}$ 5.07E-06

$\mathrm{Np} \quad 8.29 \mathrm{E}-04$

$\mathrm{U} \quad 1.56 \mathrm{E}-03$

Total 2.41E-03
Mole ratios of $\mathrm{Sr}, \mathrm{Np}, \mathrm{Pu}$ and $\mathrm{U}$ to MST

mole ratio

1.49E-04

$1.63 \mathrm{E}-04$

$2.13 \mathrm{E}-02$

$1.53 \mathrm{E}-02$

$3.69 \mathrm{E}-02$

Mole ratios of $\mathrm{Sr}, \mathrm{Np}, \mathrm{Pu}$ and $\mathrm{U}$ to MST

$\begin{array}{cc}\text { mole ratio } & \text { mole ratio } \\ 1.37 \mathrm{E}-05 & 1.37 \mathrm{E}-05 \\ 5.71 \mathrm{E}-07 & 5.71 \mathrm{E}-07 \\ 6.00 \mathrm{E}-04 & 3.62 \mathrm{E}-04 \\ 1.59 \mathrm{E}-03 & 1.41 \mathrm{E}-03 \\ 2.20 \mathrm{E}-03 & 1.78 \mathrm{E}-03\end{array}$

mole ratio

$1.66 \mathrm{E}-04$

$1.62 \mathrm{E}-04$

2.19E-02

$1.59 \mathrm{E}-02$

$3.82 \mathrm{E}-02$

$1.78 \mathrm{E}-03$
High Activity $[\mathrm{MST}]=2.0 \mathrm{~g} / \mathrm{L}$ Units mole ratio

$\mathrm{Sr}$ 7.23E-05

$\mathrm{Pu}$ 7.03E-05

$\mathrm{Np} \quad 8.86 \mathrm{E}-03$

$\mathrm{U} \quad 6.22 \mathrm{E}-03$

Total $\quad 1.52 \mathrm{E}-02$

Low Activity $[\mathrm{MST}]=2.0 \mathrm{~g} / \mathrm{L}$

$\begin{array}{cc}\text { Units } & \text { mole ratio } \\ \mathrm{Sr} & 5.64 \mathrm{E}-06 \\ \mathrm{Pu} & 4.69 \mathrm{E}-07 \\ \mathrm{~Np} & 1.43 \mathrm{E}-04 \\ \mathrm{U} & 6.39 \mathrm{E}-04 \\ \text { Total } & 7.88 \mathrm{E}-04\end{array}$

Mole ratios of Sr, Np, Pu and U to MST

mole ratio mole ratio mole ratio mole ratio $1.20 \mathrm{E}-04 \quad 6.16 \mathrm{E}-05 \quad 1.03 \mathrm{E}-04 \quad 6.86 \mathrm{E}-05$

$1.17 \mathrm{E}-04 \quad 6.74 \mathrm{E}-05$

$1.48 \mathrm{E}-02 \quad 8.86 \mathrm{E}-03$

$1.03 \mathrm{E}-02 \quad 6.30 \mathrm{E}-03$

$2.53 \mathrm{E}-02 \quad 1.53 \mathrm{E}-02$
$1.13 \mathrm{E}-04 \quad 6.69 \mathrm{E}-05$

$1.47 \mathrm{E}-02 \quad 9.11 \mathrm{E}-03$

$1.05 \mathrm{E}-02 \quad 6.55 \mathrm{E}-03$

$2.54 \mathrm{E}-02 \quad 1.58 \mathrm{E}-02$
Mole ratios of $\mathrm{Sr}, \mathrm{Np}, \mathrm{Pu}$ and $\mathrm{U}$ to $\mathrm{MST}$

mole ratio mole ratio

9.41E-06 5.66E-06

4.11E-06 7.28E-07

7.17E-04 2.48E-04

1.08E-03 6.55E-04

$1.81 \mathrm{E}-03 \quad 9.10 \mathrm{E}-04$ - mole ratio mole ratio

9.41E-06 5.66E-06

$1.21 \mathrm{E}-06 \quad 2.34 \mathrm{E}-07$

$4.13 \mathrm{E}-04 \quad 1.49 \mathrm{E}-04$

$1.09 \mathrm{E}-03 \quad 5.80 \mathrm{E}-04$

$1.52 \mathrm{E}-03 \quad 7.35 \mathrm{E}-04$ mole ratio

1.14E-04

1.12E-04

1.51E-02

1.09E-02

2.63E-02

mole ratio

9.41E-06

$6.03 \mathrm{E}-07$

2.49E-04

9.66E-04

$1.23 \mathrm{E}-03$ 
Appendix 25.

Statistical Analysis of Mixing Trials

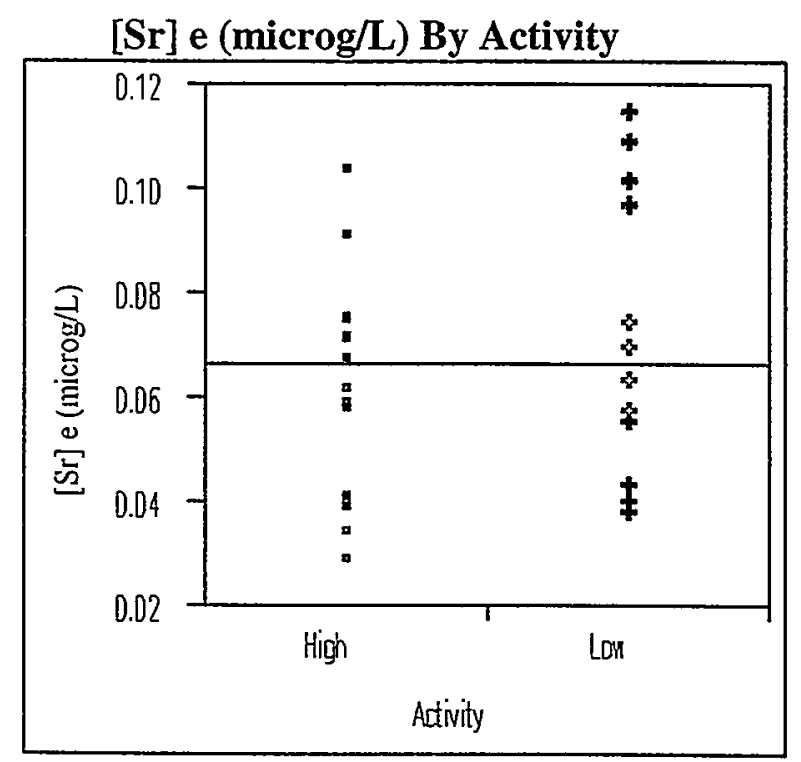

[Sr] e (microg/L) By Mixing

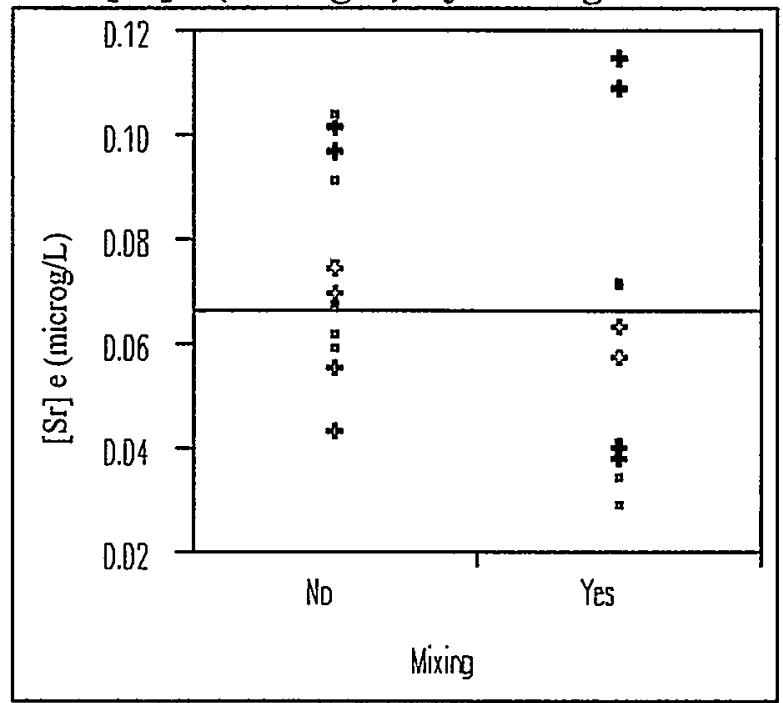

[Sr] e (microg/L) By Temp (Deg C)

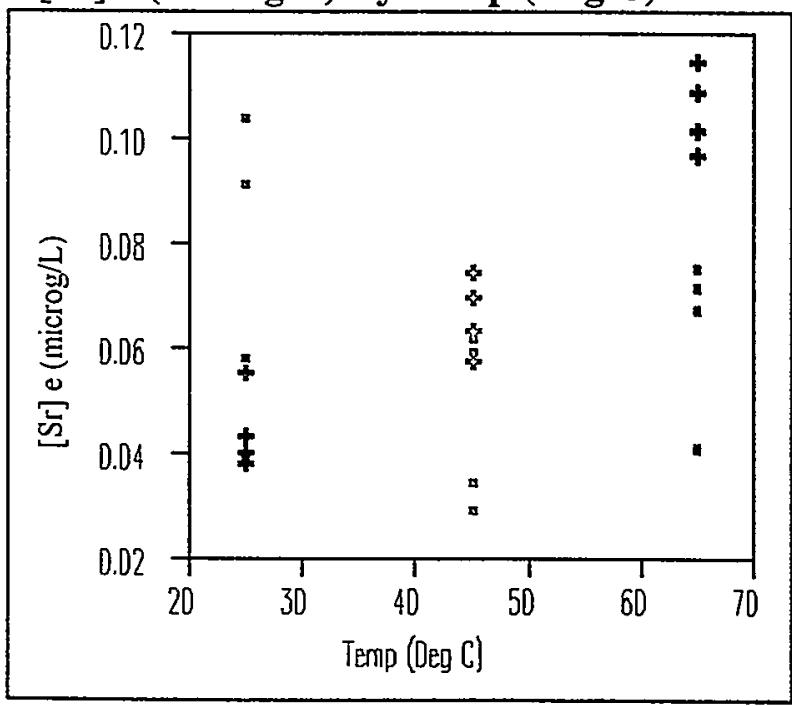

[Np] e (microg/L) By Activity

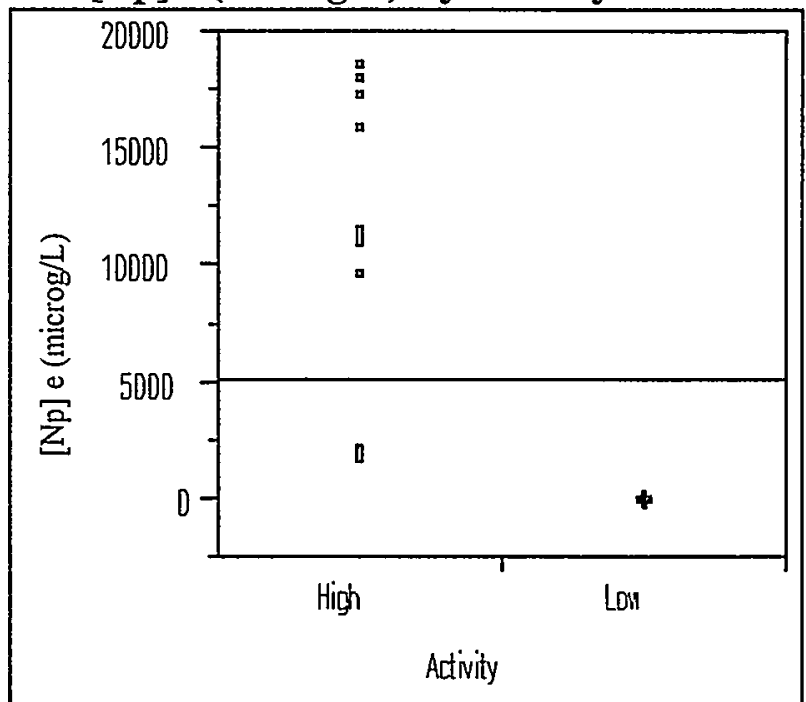


[Np] e (microg/L) By Temp (Deg C)

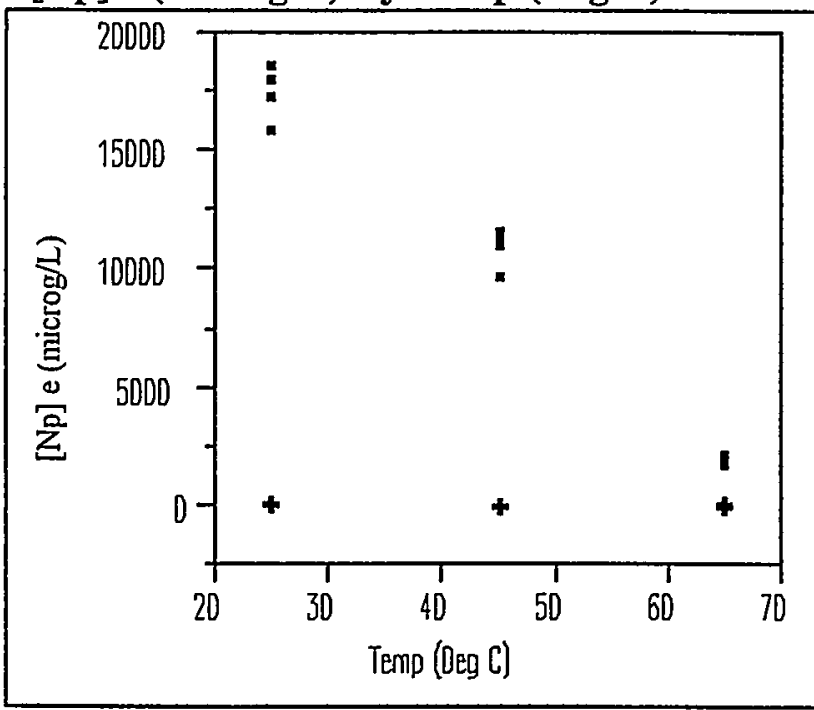

\section{[Np] e (microg/L) By Mixing}

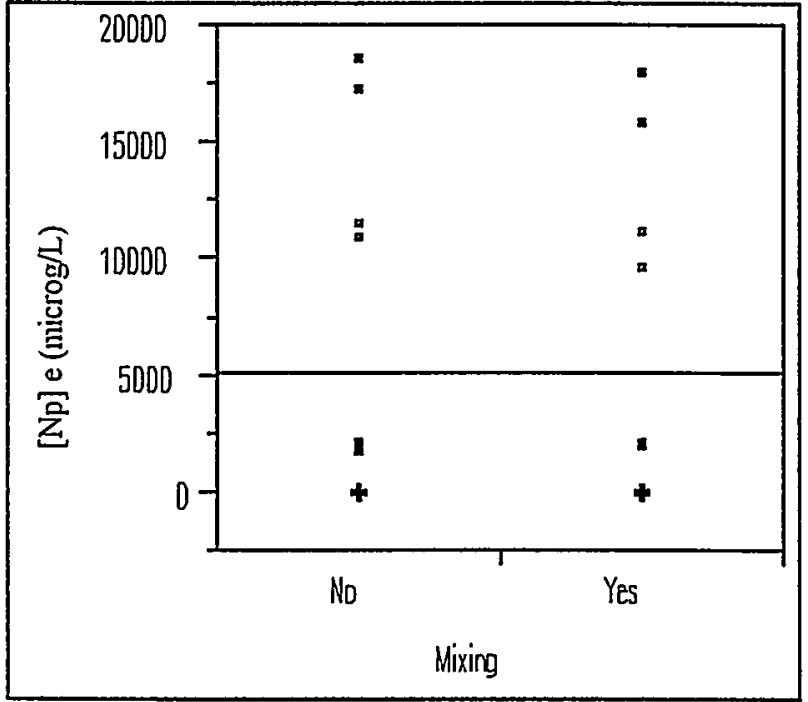

[U] e (microg/L) By Activity

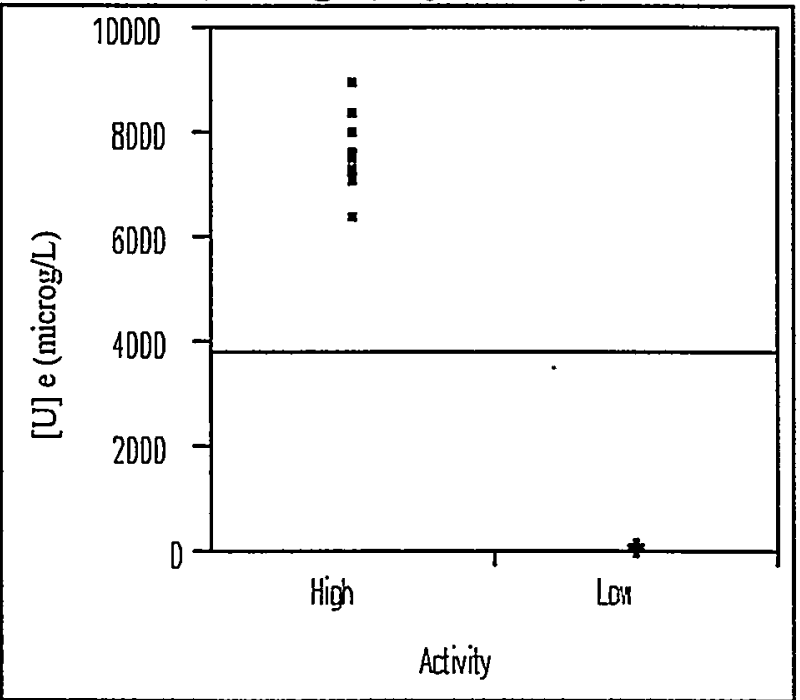

$[\mathrm{U}]$ e (microg/L) By Temp (Deg C)

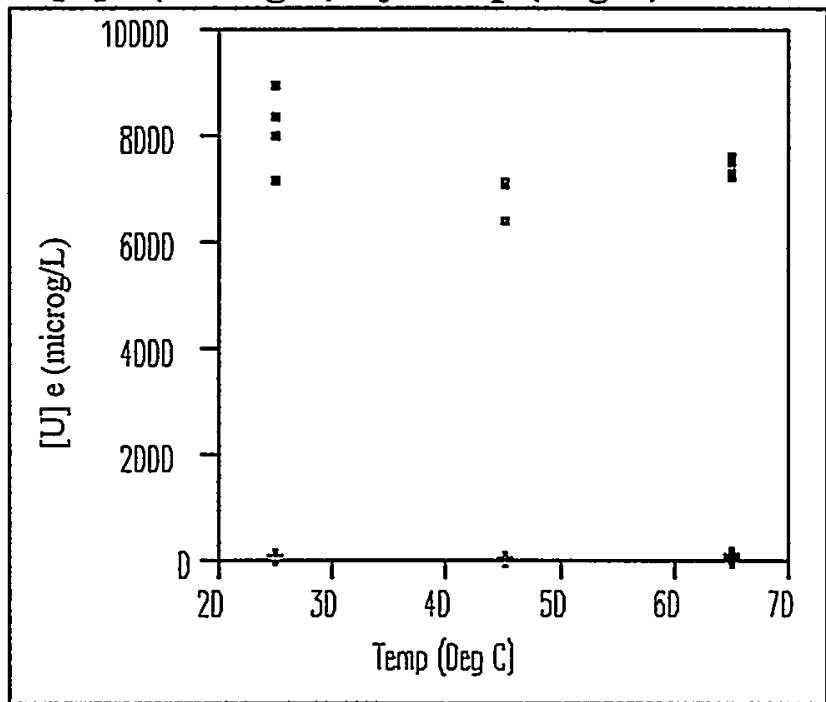

[U] e (microg/L) By Mixing

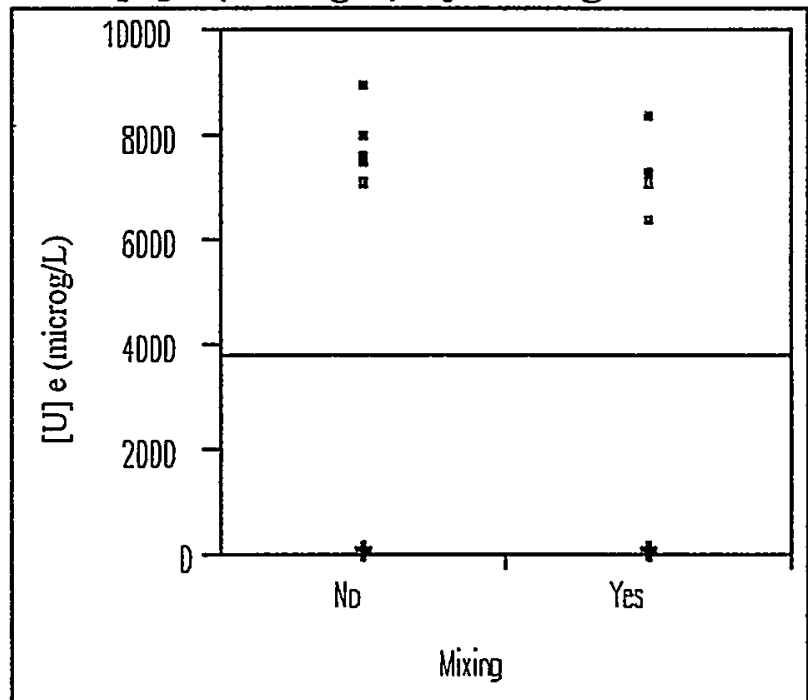

[Pu] e (microg/L) By Activity

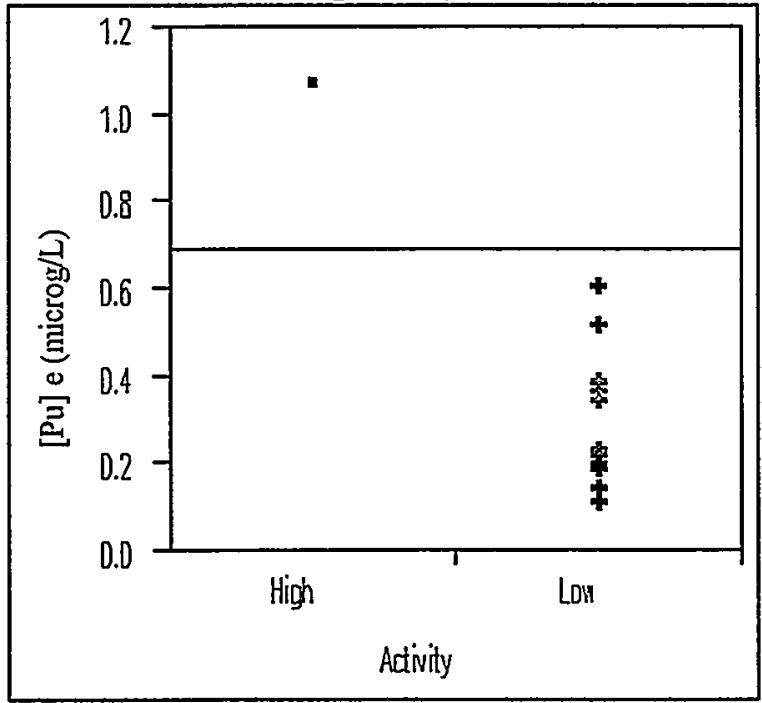


[Pu] e (microg/L) By Temp (Deg C)

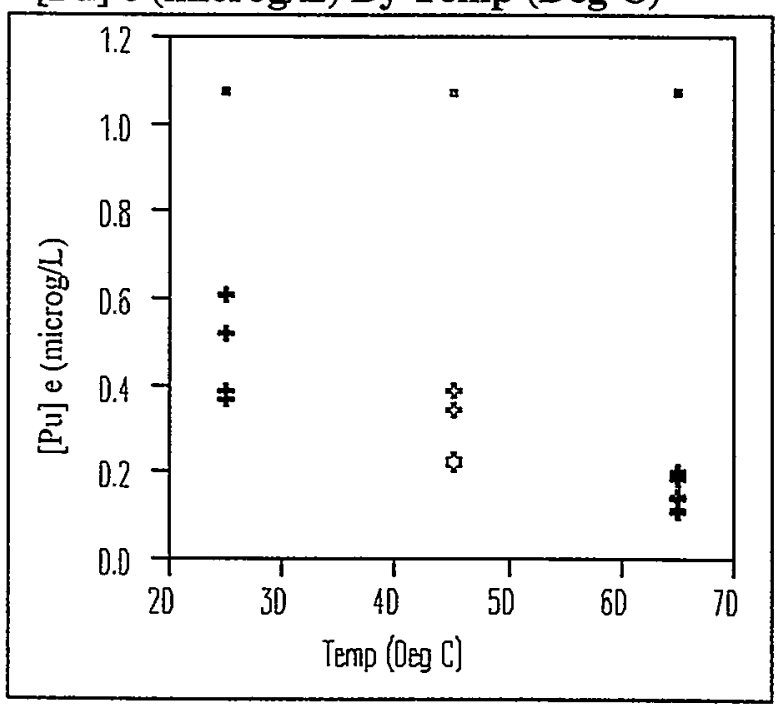

[Pu] e (microg/L) By Mixing

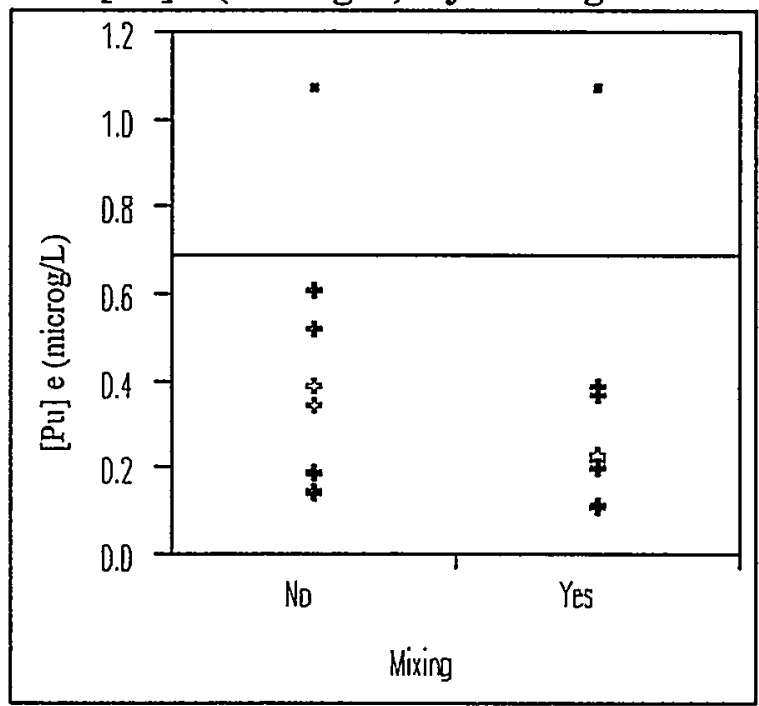


Response: [Sr] e (microg/L)

RSquare

RSquare Adj

Root Mean Square Error

Mean of Response

Observations (or Sum Wgts)
0.78336

0.723182

0.013283

0.066838

24
Source

Lack of Fit

Pure Error

Total Error

Max RSq

0.9382
Summary of Fit
Lack of Fit

Mean Square

0.000378

0.000075
F Ratio 5.0162

Prob $>$ F

0.0086
0.00090523

0.00317568
Parameter Estimates

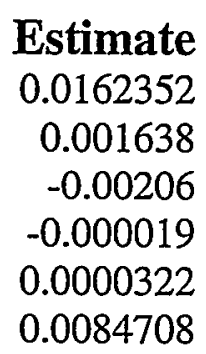

Std Error

0.0142

0.000256

0.001088

0.000005

0.000012

0.002711
Prob $>|t|$

0.2679

$<.0001$

0.0746

0.0006

0.0120

2.79

3.12

0.0059

\section{Whole-Model Test}

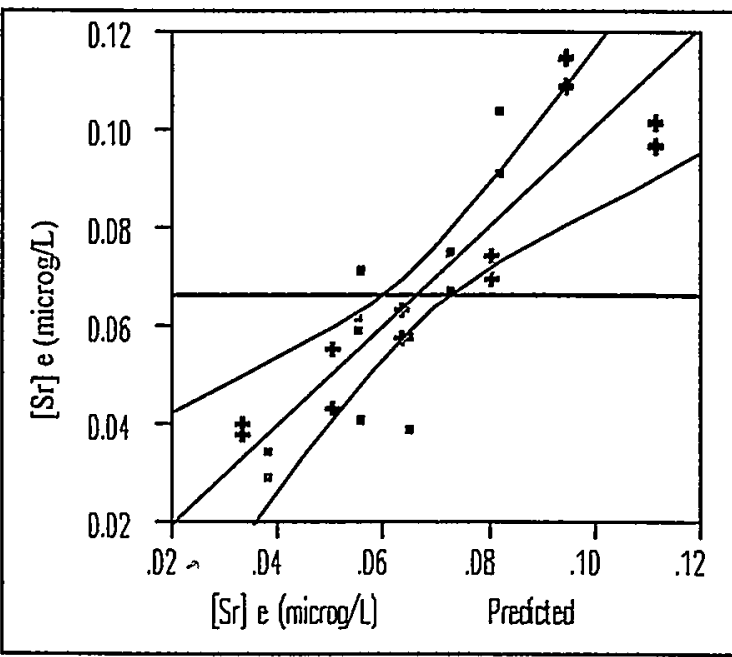

Residual Plot

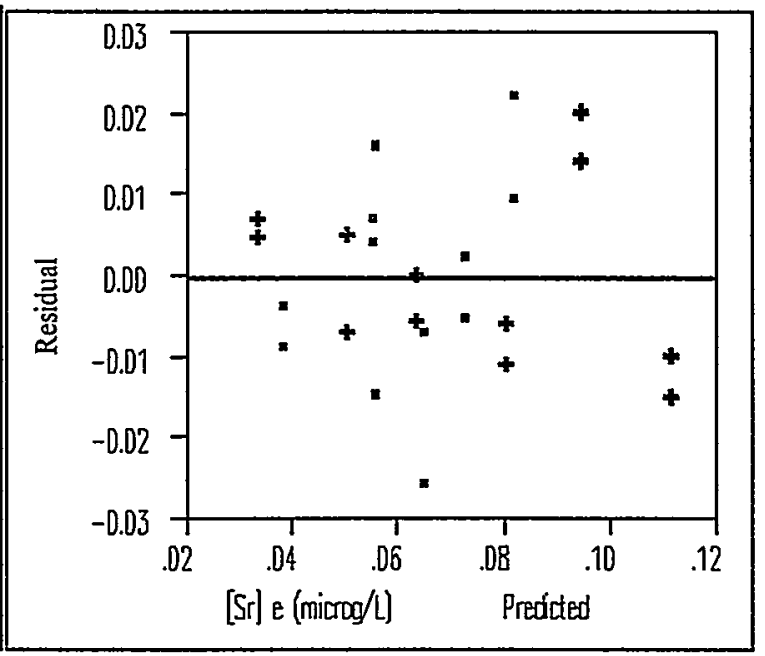

Source

Model

Error

C Total
DF

5

18

23

\section{(a)}

$(8$

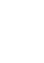

(8)

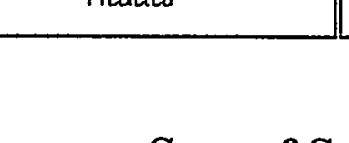

Analysis of Variance 


\begin{tabular}{|c|c|c|c|}
\hline \multicolumn{4}{|c|}{ Response: $[\mathrm{Np}]$ e (microg/L) } \\
\hline $\mathrm{RSq}$ & & 0.994623 & \\
\hline RSq & & 0.993129 & \\
\hline Root & Square Error & 574.3948 & \\
\hline Mea: & sponse & 5083.521 & \\
\hline Obse & is (or Sum Wgts) & 24 & \\
\hline DF & Sum of Squares & Mean Square & $\begin{array}{l}\text { Lack of Fit } \\
\text { F Ratio }\end{array}$ \\
\hline 6 & 1189166.4 & 198194 & 0.5007 \\
\hline 12 & 4749562.2 & 395797 & Prob $>$ F \\
\hline 18 & 5938728.6 & & 0.7964 \\
\hline
\end{tabular}

Source

Lack of Fit

Pure Error

Total Error

Max RSq

0.9957
Term

Intercept

Temp (Deg C)

[Np]o (microg/L

[Np]o (m*Temp (De

[Np]o $(m *[N p] o(m$

Mixing[No-Yes]
RSquare

RSquare Adj

Root Mean Square Error

Mean of Response
0.994623

0.993129

574.3948

24

\section{F Ratio \\ Prob $>$ F \\ 0.7964}

Whole-Model Test

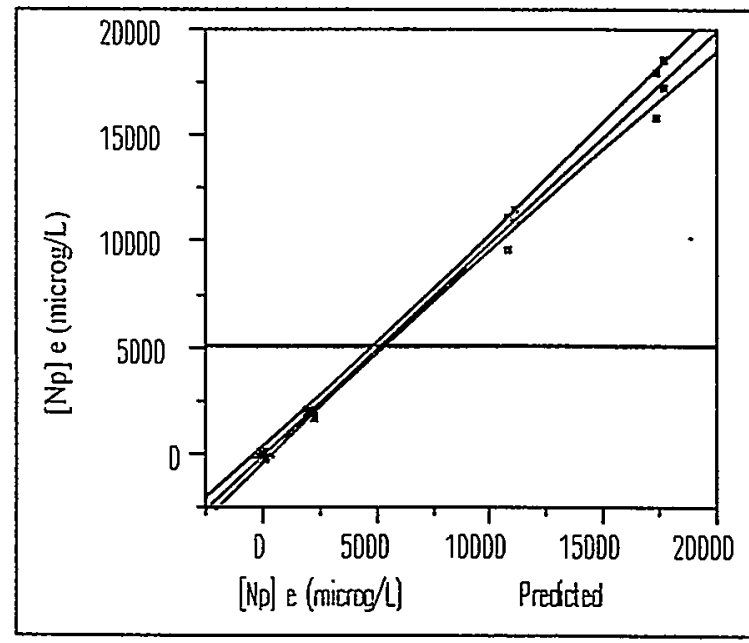

Estimate
-4910.447
55.701983
3.754129
-0.014407
-0.000094
148.12917

Std Error
1156.018
14.90214
0.74355
0.000522
0.000026
117.2478

Parameter Estimates

$\begin{array}{rr}\text { t Ratio } & \text { Prob }>|\mathbf{t}| \\ -4.25 & 0.0005 \\ 3.74 & 0.0015 \\ 5.05 & <.0001 \\ -27.60 & <.0001 \\ -3.67 & 0.0017 \\ 1.26 & 0.2226\end{array}$

Residual Plot

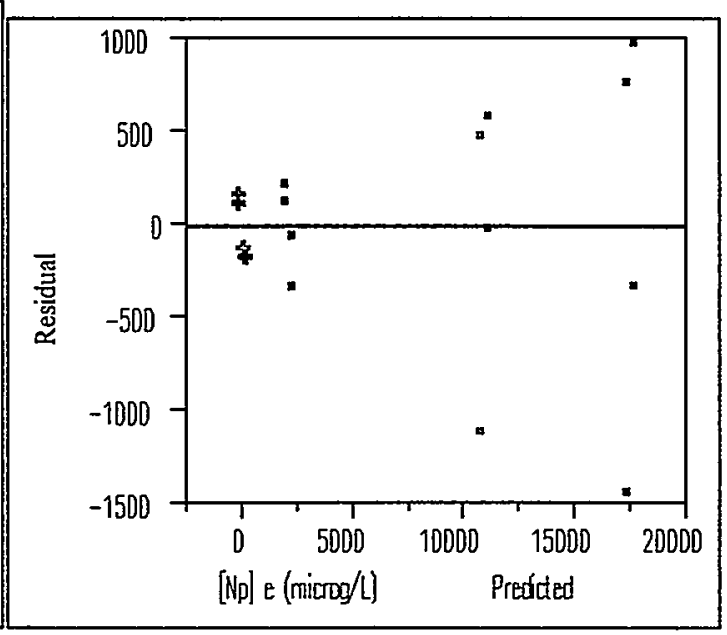

Source

Model

Error

C Total

Analysis of Variance

\section{DF}

5

18

23
Sum of Squares

1098449960

5938728.62

1104388688

$\begin{array}{rr}\text { Mean Square } & \text { F Ratio } \\ 2.1969 \mathrm{e} 8 & 665.8698 \\ 329929.4 & \text { Prob }>\text { F } \\ & <.0001\end{array}$




\begin{tabular}{lr}
\multicolumn{2}{c}{ Response: [Pu] e (microg/L) } \\
Summary of Fit \\
RSquare & 0.987439 \\
RSquare Adj & 0.984795 \\
Root Mean Square Error & 0.049667 \\
Mean of Response & 0.694417 \\
Observations (or Sum Wgts) & 24
\end{tabular}

Source

Lack of Fit

DF

7

Pure Error

Total Error

Max RSq

0.9974

\section{Term}

Intercept

Temp (Deg C)

[Pu]o (microg/L

[Pu]o (m*Temp (De

12

19

\author{
Sum of Squares \\ 0.03718282 \\ 0.00968700 \\ 0.04686982
}

\section{Estimate \\ 0.6345469 \\ $-0.007309$ \\ 0.0018694 \\ 0.0000376 \\ 0.0278333

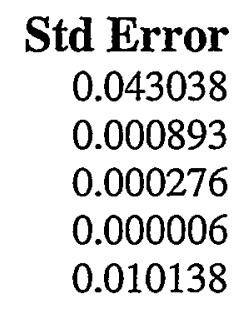

Lack of Fit

Mean Square

0.005312

0.000807
F Ratio 6.5802

Prob $>$ F

0.0024
Parameter Estimates t Ratio

14.74

$-8.18$

6.77

6.49

2.75
Prob $>|t|$

$<.0001$

$<.0001$

$<.0001$

$<.0001$

0.0129

Whole-Model Test
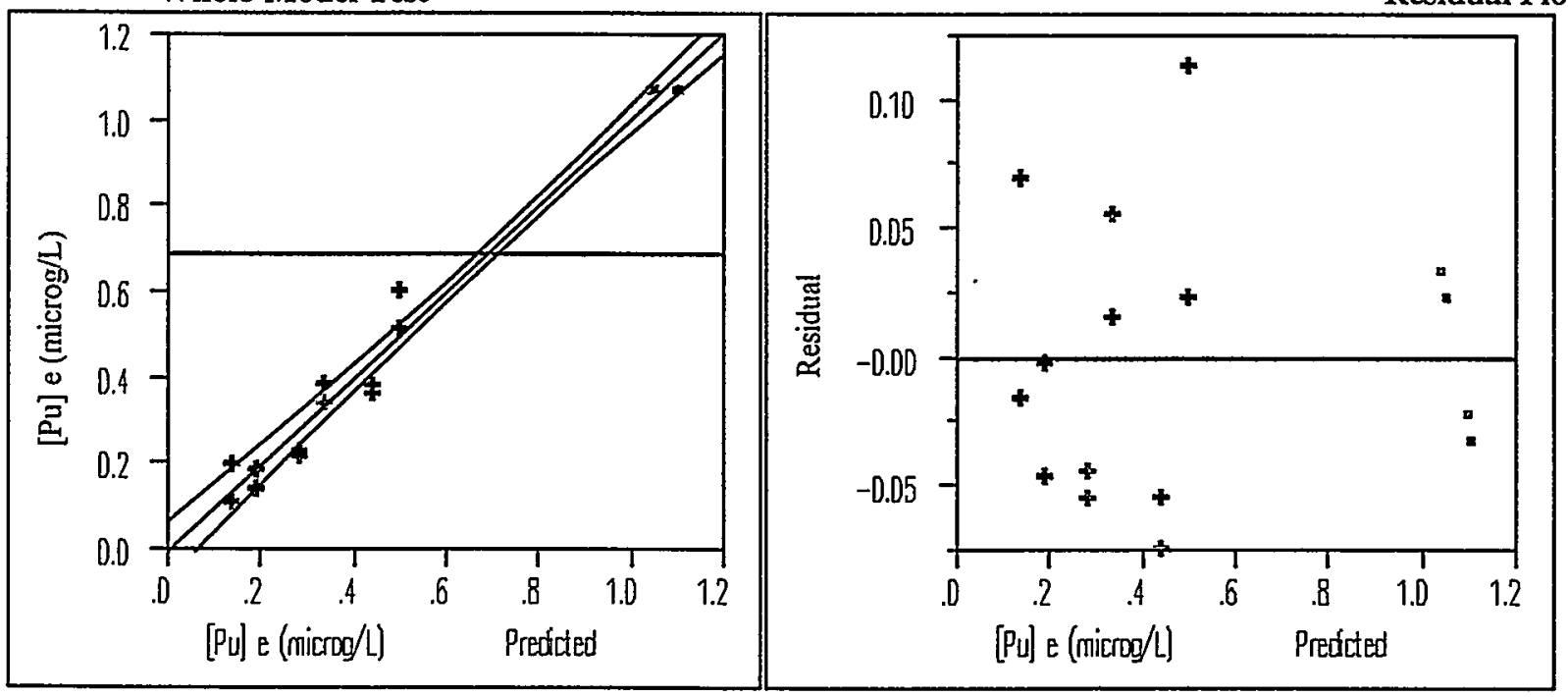

Analysis of Variance

Source

Model

Error

C Total
DF

4

19

23
Sum of Squares

3.6845200

0.0468698

3.7313898
Mean Square

0.921130

0.002467
F Ratio

373.4059

Prob $>$ F 


\begin{tabular}{lr}
\multicolumn{2}{c}{ Response: [U] e (microg/L) } \\
Summary of Fit \\
RSquare & 0.99439 \\
RSquare Adj & 0.99241 \\
Root Mean Square Error & 333.4778 \\
Mean of Response & 3816.237 \\
Observations (or Sum Wgts) & 24
\end{tabular}

Source

Lack of Fit

Pure Error

Total Error

Max RSq

0.9956

\section{Term}

Intercept

Temp (Deg C)

[U]o (microg/L)

Temp (De*Temp (De

Temp (De*[U]o (mi

[U]o (mi*[U]o (mi

Mixing[No-Yes]

\section{DF}

5

12

17
Lack of Fit

Mean Square

81742

123485
F Ratio

0.6620

Prob $>$ F

0.6592
Parameter Estimates

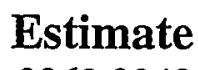

9962.9249

178.16786

$-6.851213$

$-2.098337$

$-0.009513$

0.0003471

111.20417

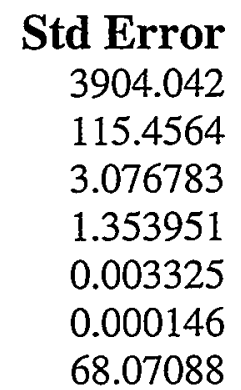

t Ratio

2.55

1.54

$-2.23$

$-1.55$

$-2.86$

2.38

1.63
Prob $>|t|$

0.0206

0.1412

0.0398

0.1396

0.0108

0.0290

0.1207

Whole-Model Test
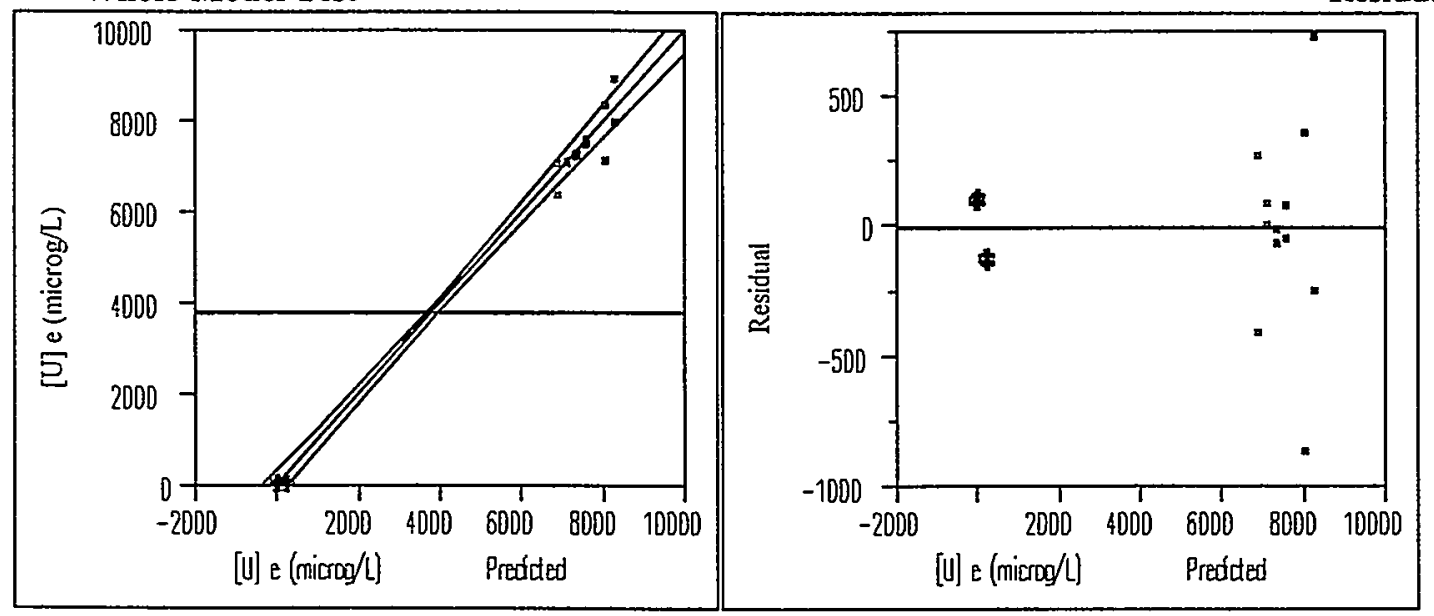

Residual Plot

Analysis of Variance

$\begin{array}{lr}\text { Source } & \text { DF } \\ \text { Model } & 6 \\ \text { Error } & 17 \\ \text { C Total } & 23\end{array}$

Sum of Squares

335118955

1890527

337009482

$\begin{array}{rr}\text { Mean Square } & \text { F Ratio } \\ 55853159 & 502.2428 \\ 111207.5 & \begin{array}{r}\text { Prob }>\text { F } \\ <.0001\end{array}\end{array}$




\begin{tabular}{lr}
\multicolumn{2}{c}{ Response: $\ln \{[\mathrm{U}]$ e $($ microg/L)\} } \\
Summary of Fit
\end{tabular}

$\begin{array}{lrrrr}\text { Source } & \text { DF } & \text { Sum of Squares } & \text { Mean Square } & \text { F Ratio } \\ \text { Lack of Fit } & 6 & 0.03552834 & 0.005921 & 0.5624 \\ \text { Pure Error } & 12 & 0.12633490 & 0.010528 & \text { Prob }>\text { F } \\ \text { Total Error } & 18 & 0.16186324 & & 0.7525\end{array}$

Max RSq

0.9989

\section{Term}

Intercept

Temp (Deg C)

[U]o (microg/L)

Temp (De*Temp (De

Temp (De*[U]o (mi

Mixing[No-Yes]
Estimate

4.0706905

$-0.009749$

0.0002774

0.0001967

$-8.229 \mathrm{e}-7$

0.0162623

Std Error
0.20078
0.009406
0.000006
0.000103
$1.296 \mathrm{e}-7$
0.019357

Parameter Estimates

$\begin{array}{rr}\text { t Ratio } & \text { Prob }>|\mathbf{t}| \\ 20.27 & <.0001 \\ -1.04 & 0.3137 \\ 43.85 & <.0001 \\ 1.92 & 0.0714 \\ -6.35 & <.0001 \\ 0.84 & 0.4119\end{array}$

Whole-Model Test

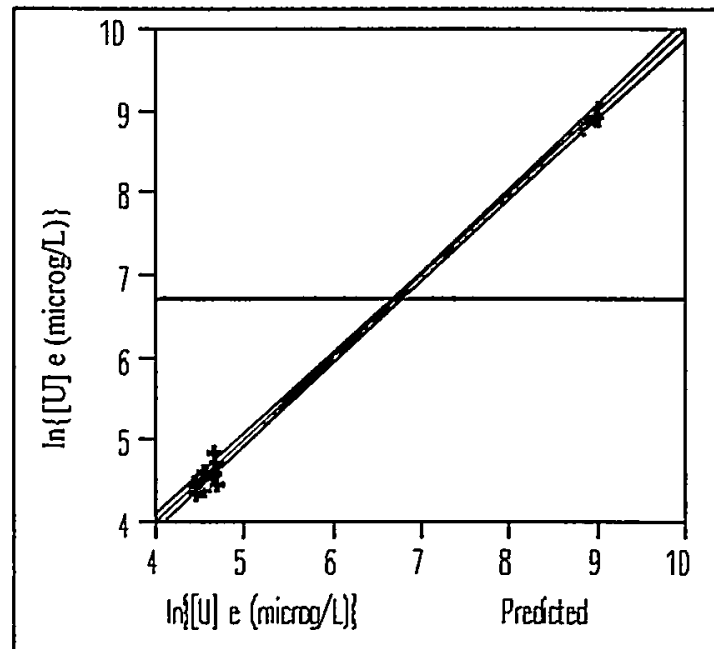

Residual Plot

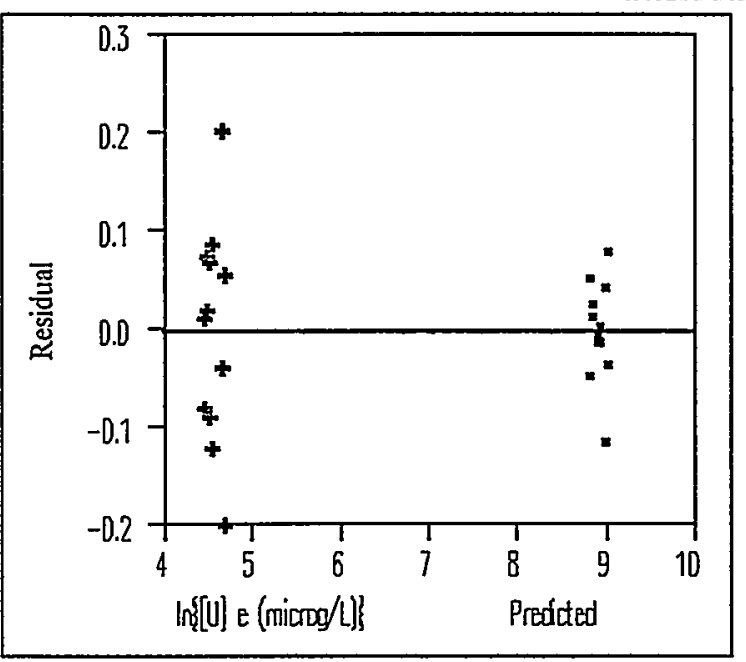

Analysis of Variance

$\begin{array}{lrrrr}\text { Source } & \text { DF } & \text { Sum of Squares } & \text { Mean Square } & \text { F Ratio } \\ \text { Model } & 5 & 114.34403 & 22.8688 & 2543.125 \\ \text { Error } & 18 & 0.16186 & 0.0090 & \text { Prob }>\text { F } \\ \text { C Total } & 23 & 114.50589 & & <.0001\end{array}$




\section{Appendix 26.}

Statistical Analysis of NaTPB and Sludge Addition (Spiked) Trials

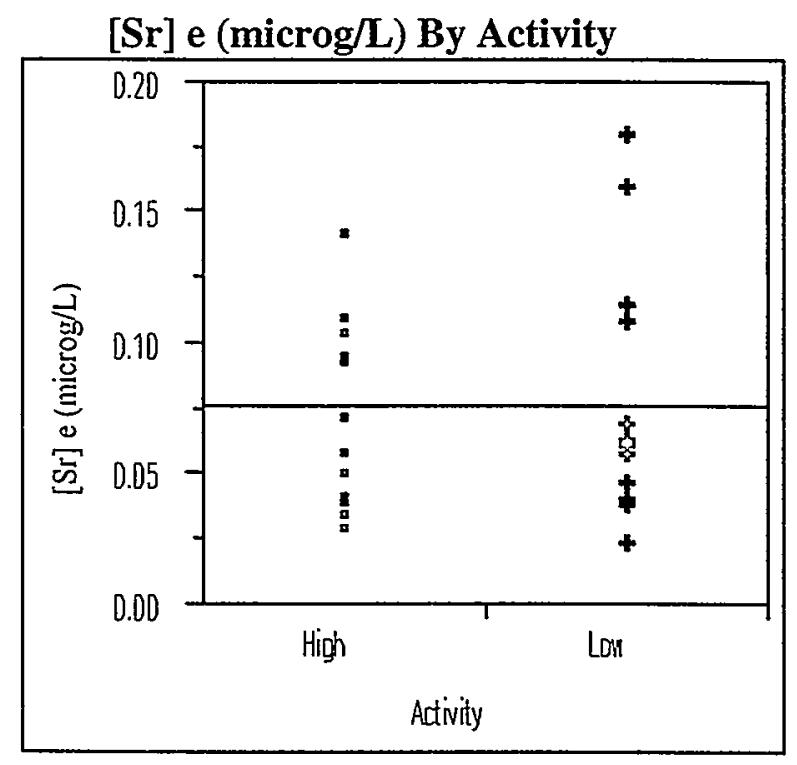

[Sr] e (microg/L) By Spiked

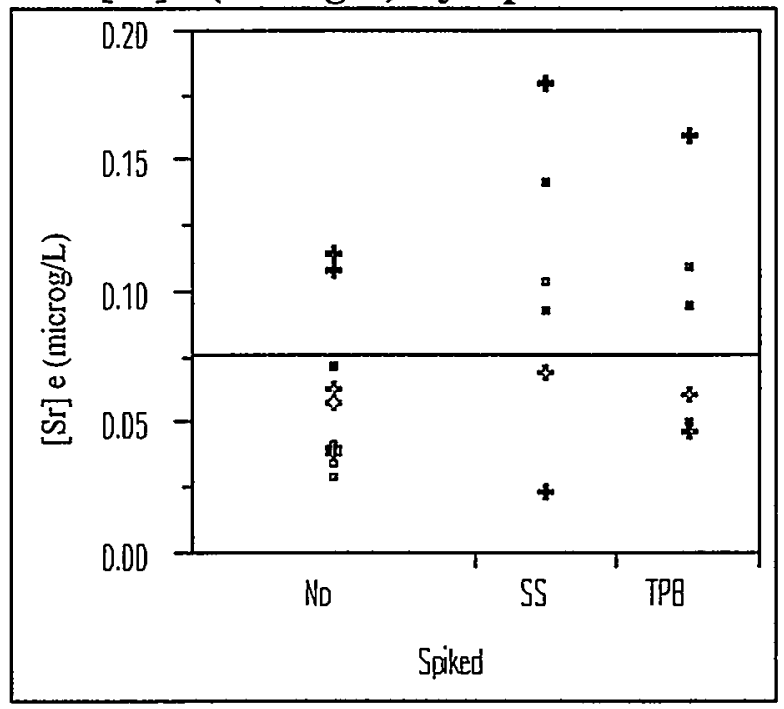

[Sr] e (microg/L) By Temp (Deg C)

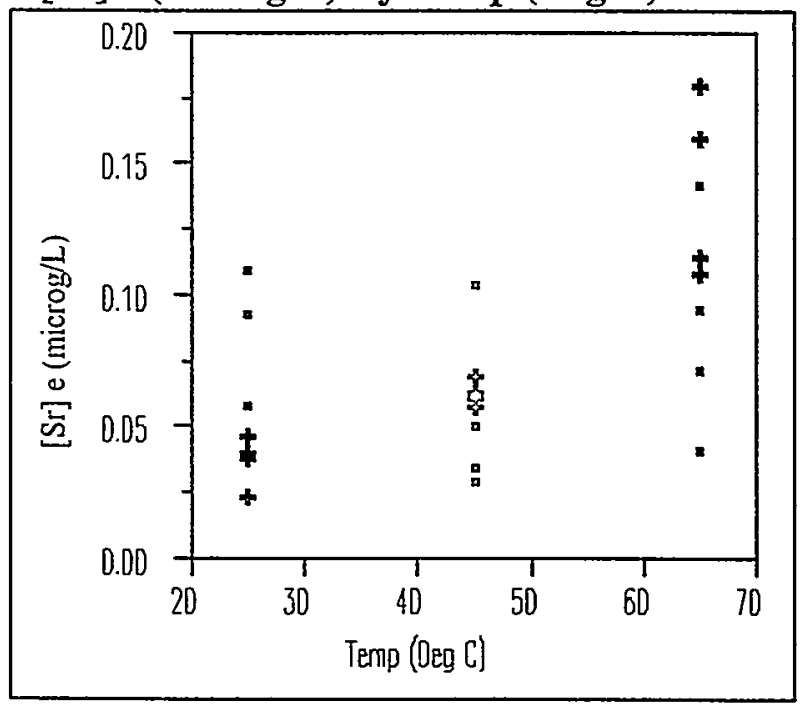

[Np] e (microg/L) By Activity

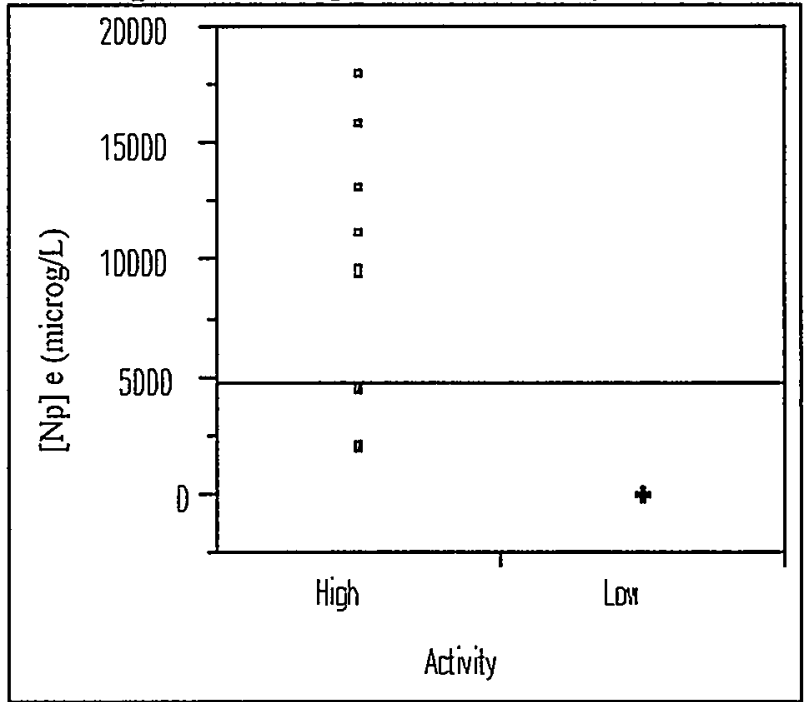


[Np] e (microg/L) By Temp (Deg C)

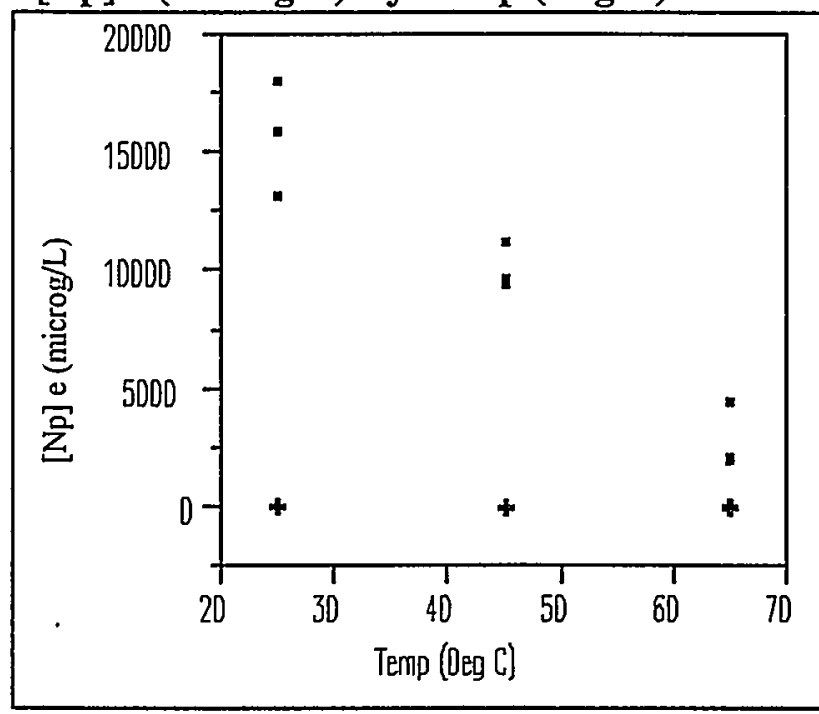

\section{[Np] e (microg/L) By Spiked}

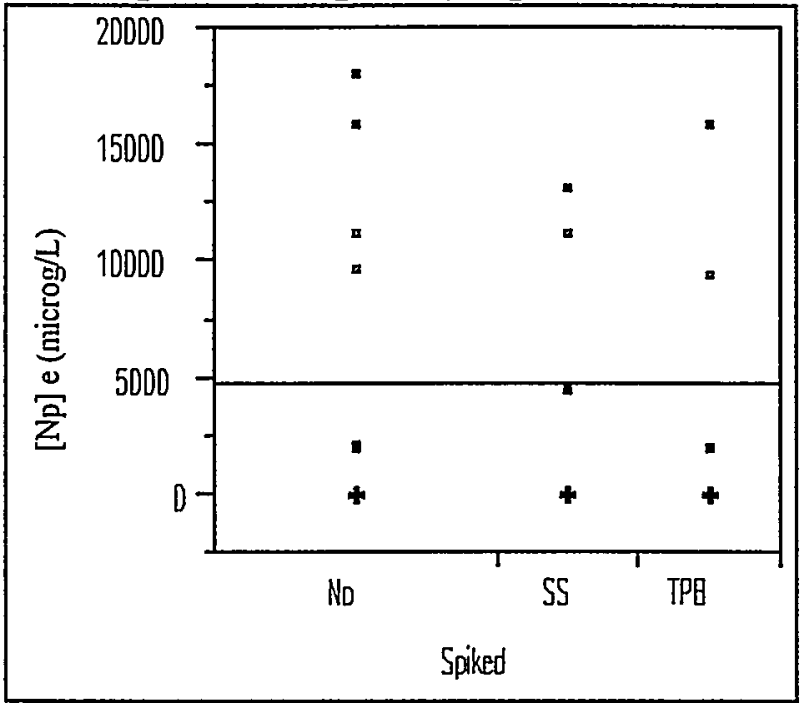

[U] e (microg/L) By Activity

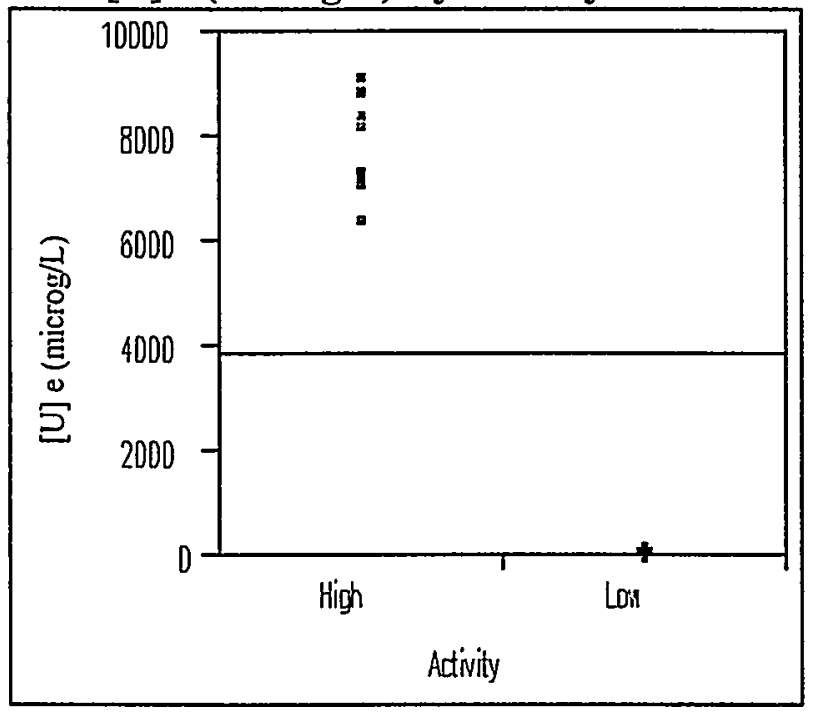

[U] e (microg/L) By Temp (Deg C)

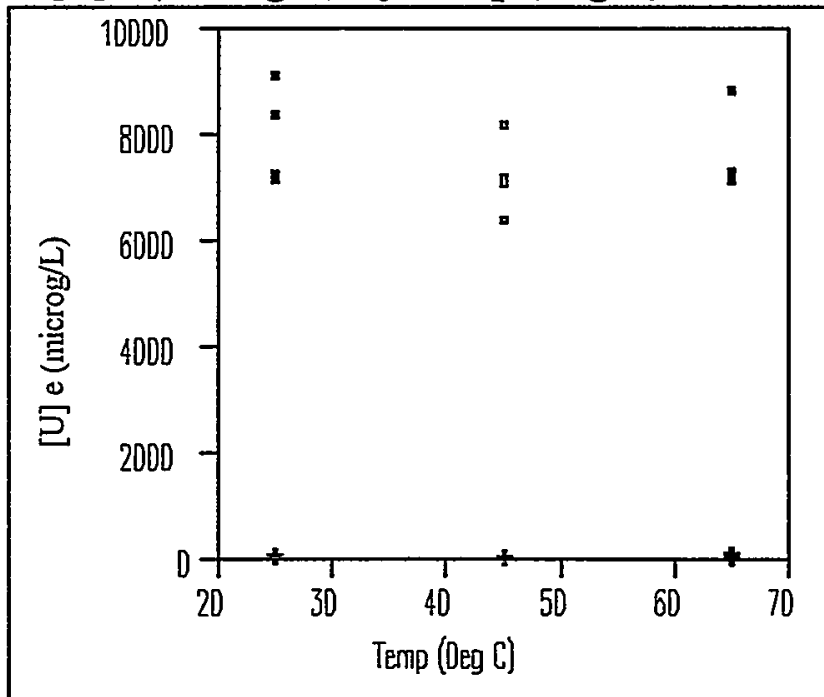

[U] e (microg/L) By Spiked

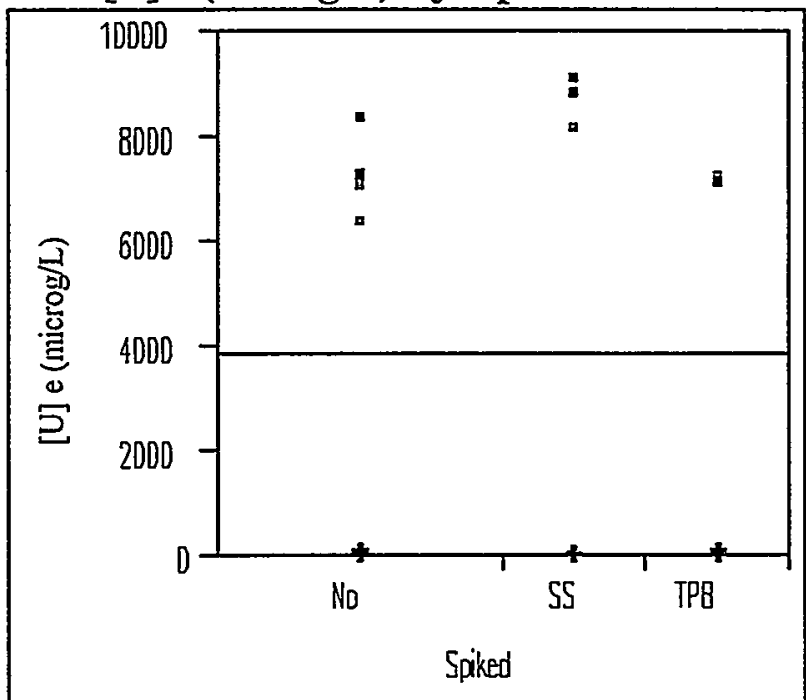

[Pu] e (microg/L) By Activity

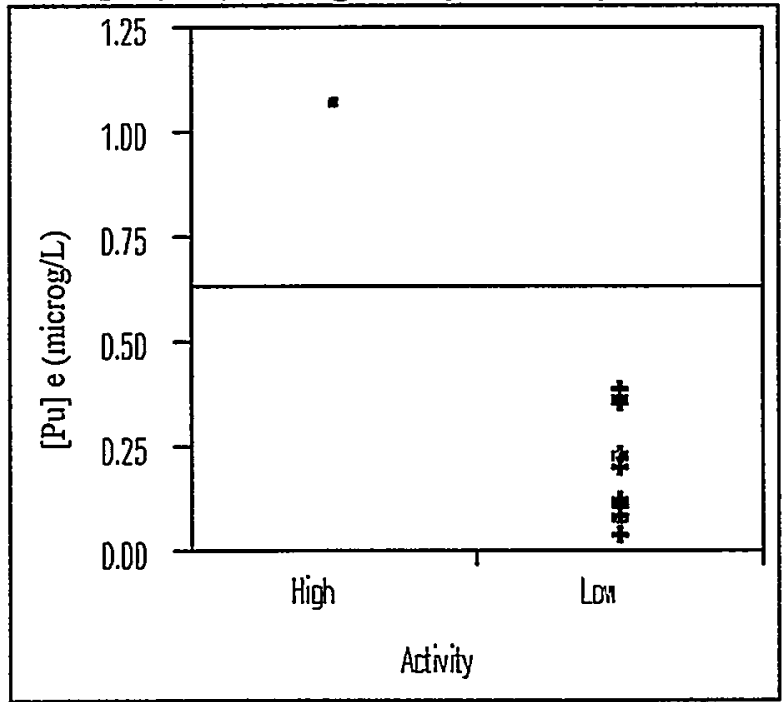


$[\mathrm{Pu}]$ e (microg/L) By Temp (Deg C)

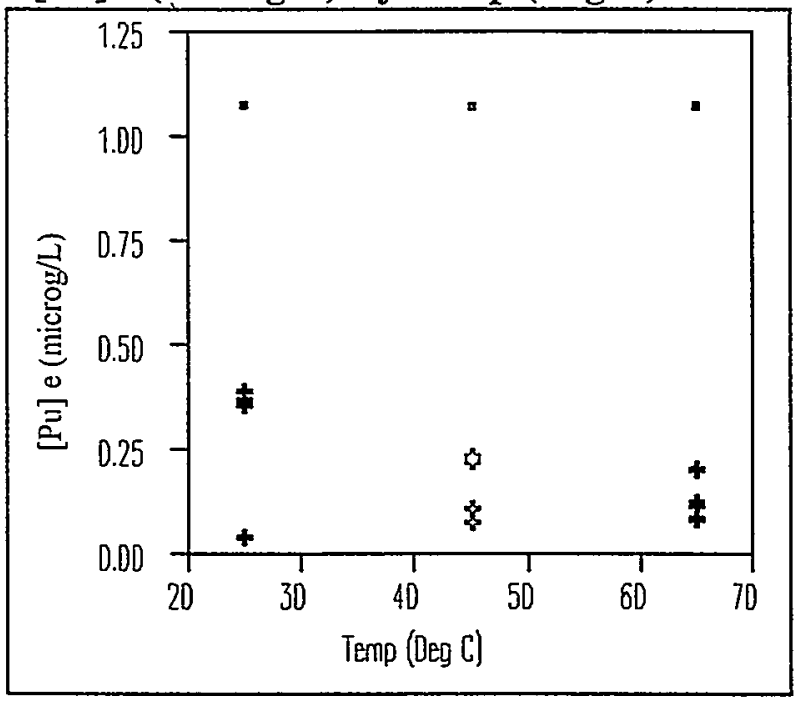

[Pu] e (microg/L) By Spiked

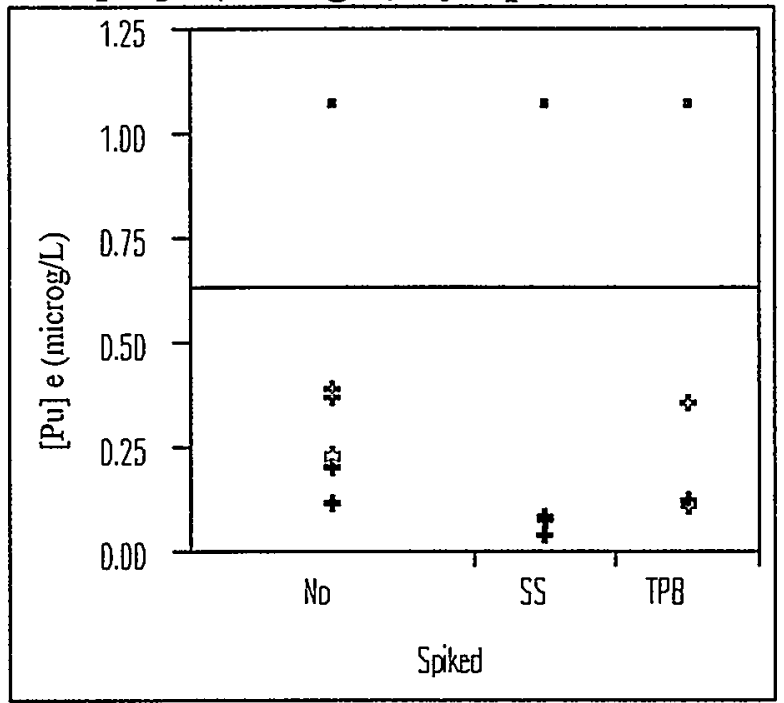


RSquare

RSquare Adj

Root Mean Square Error

Mean of Response

Observations (or Sum Wgts)

Source

Lack of Fit

Pure Error

Total Error

Max RSq

0.9836

Term

Intercept

Temp (Deg C)

[Sr]o (microg/L

Temp (De*Temp (De

Temp (De*[Sr]o (m

Spiked[SS-zNo]

Spiked[TPB-zNo]
DF

11

6

17
Response: [Sr] e (microg/L)

Summary of Fit

0.82359

0.761328

0.020963

0.07675

24

Mean Square

0.000616

0.000116
Lack of Fit

F Ratio

5.3055

Prob $>$ F

0.0262
0.00677429

0.00069646

0.00747075
Parameter Estimates

$\begin{array}{rrrr}\text { Estimate } & \text { Std Error } & \text { t Ratio } & \text { Prob }>\mid \text { t } \mid \\ 0.075559 & 0.044936 & 1.68 & 0.1110 \\ -0.003034 & 0.002092 & -1.45 & 0.1651 \\ 0.0012373 & 0.000327 & 3.79 & 0.0015 \\ 0.0000648 & 0.000023 & 2.85 & 0.0111 \\ -0.00003 & 0.000007 & -4.38 & 0.0004 \\ 0.0197056 & 0.00669 & 2.95 & 0.0090 \\ 0.0048056 & 0.00669 & 0.72 & 0.4823\end{array}$

Whole-Model Test

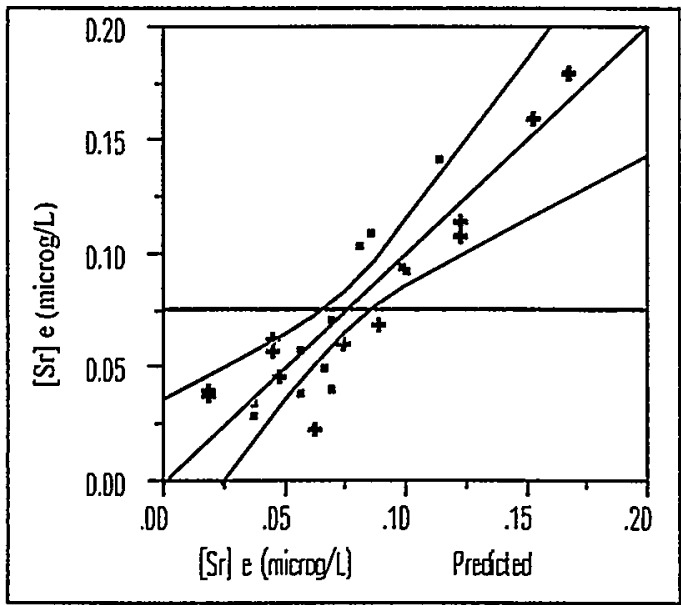

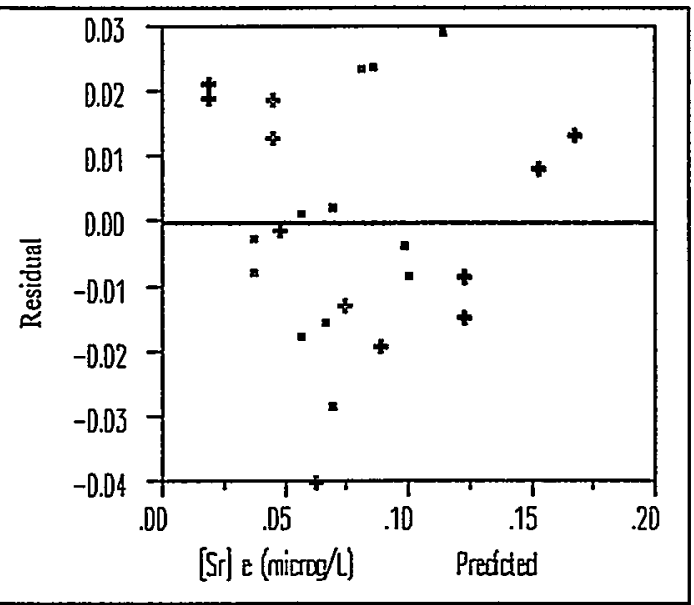

Analysis of Variance

$\begin{array}{lrrrr}\text { Source } & \text { DF } & \text { Sum of Squares } & \text { Mean Square } & \text { F Ratio } \\ \text { Model } & 6 & 0.03487805 & 0.005813 & 13.2277 \\ \text { Error } & 17 & 0.00747075 & 0.000439 & \text { Prob }>\text { F } \\ \text { C Total } & 23 & 0.04234880 & & <.0001\end{array}$




\begin{tabular}{lr}
\multicolumn{2}{c}{ Response: [Np] e (microg/L) } \\
Summary of Fit \\
RSquare & 0.979607 \\
RSquare Adj & 0.972409 \\
Root Mean Square Error & 1052.326 \\
Mean of Response & 4826.508 \\
Observations (or Sum Wgts) & 24
\end{tabular}

Source

Lack of Fit

DF

11

6

17

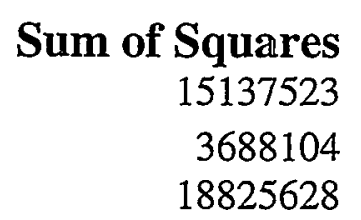

Pure Error
Total Error

18825628

Mean Square

1376138

614684

Lack of Fit

F Ratio 2.2388

Max RSq

0.9960

\section{Term}

Intercept

Temp (Deg C)

[Np]o (microg/L

Temp (De*[Np]o (m

[Np]o ( $\mathrm{m}^{*}[\mathrm{~Np}] \mathrm{o}(\mathrm{m}$

Spiked[SS-zNo]

Spiked[TPB-zNo]
Estimate
$-4983.857$
55.318278
3.7396569
$-0.012261$
$-0.000098$
47.269444
$-192.4472$

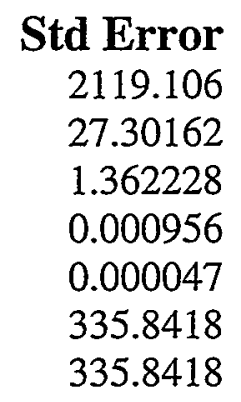

Parameter Estimates

Ratio
-2.35
2.03
2.75
-12.82
-2.08
0.14
-0.57

Prob $>|t|$

0.0310

0.0587

0.0138

$<.0001$

0.0530

0.8897

0.5741

Whole-Model Test
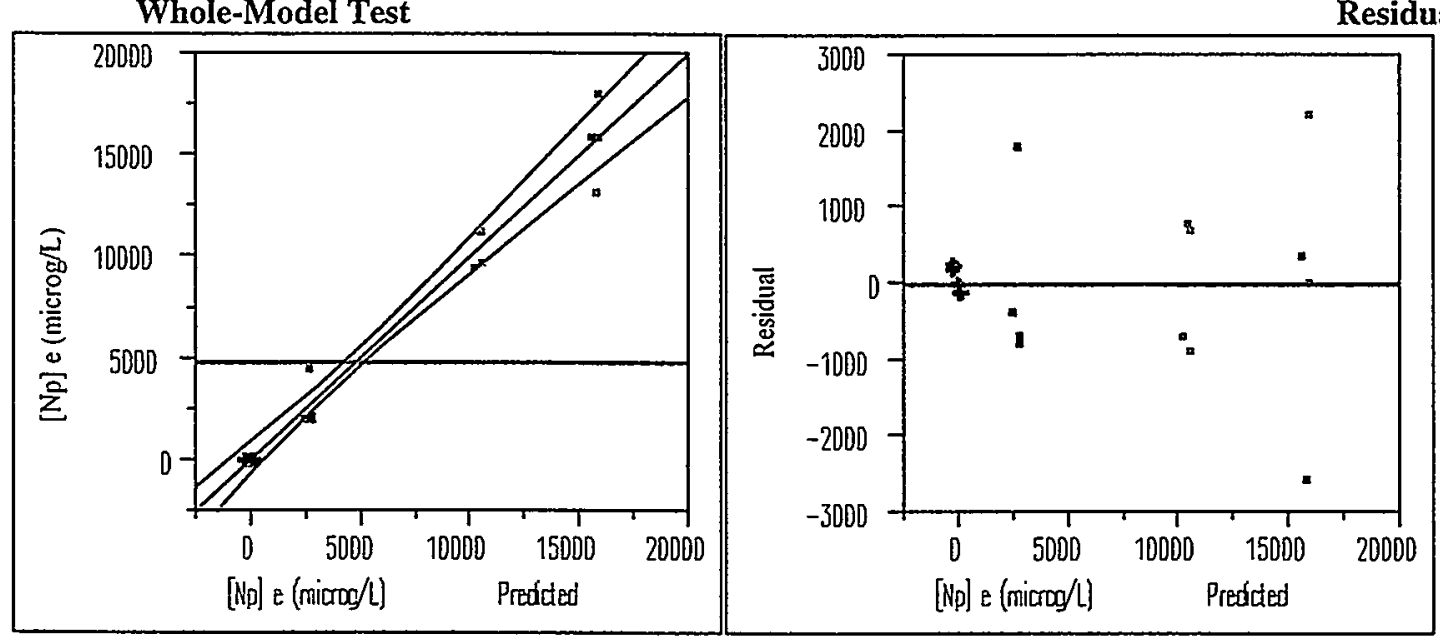

$\begin{array}{lrrrr}\text { Source } & \text { DF } & \text { Sum of Squares } & \text { Mean Square } & \text { F Ratio } \\ \text { Model } & 6 & 904307220 & 1.5072 \mathrm{e} 8 & 136.1019 \\ \text { Error } & 17 & 18825628 & 1107390 & \text { Prob }>\text { F } \\ \text { C Total } & 23 & 923132847 & & <.0001\end{array}$




\begin{tabular}{lr}
\multicolumn{2}{c}{ Response: [Pu] e (microg/L) } \\
Summary of Fit \\
RSquare & 0.984464 \\
RSquare Adj & 0.980148 \\
Root Mean Square Error & 0.064295 \\
Mean of Response & 0.635908 \\
Observations (or Sum Wgts) & 24
\end{tabular}

Source

Lack of Fit

DF

Pure Error

Total Error

Max RSq

0.9992 12

6
Sum of Squares
0.07045123
0.00395850

18
Lack of Fit

Mean Square 0.005871

0.000660
F Ratio 8.8987

Prob $>$ F

0.0069

Parameter Estimates

$\begin{array}{rrrr}\text { Estimate } & \text { Std Error } & \text { t Ratio } & \text { Prob }>|\mathbf{t}| \\ 0.2229717 & 0.041386 & 5.39 & <.0001 \\ -0.001661 & 0.000826 & -2.01 & 0.0597 \\ 0.0143264 & 0.003674 & 3.90 & 0.0011 \\ -0.000047 & 0.000017 & -2.78 & 0.0122 \\ -0.052717 & 0.020519 & -2.57 & 0.0193 \\ 0.0118167 & 0.020519 & 0.58 & 0.5718\end{array}$
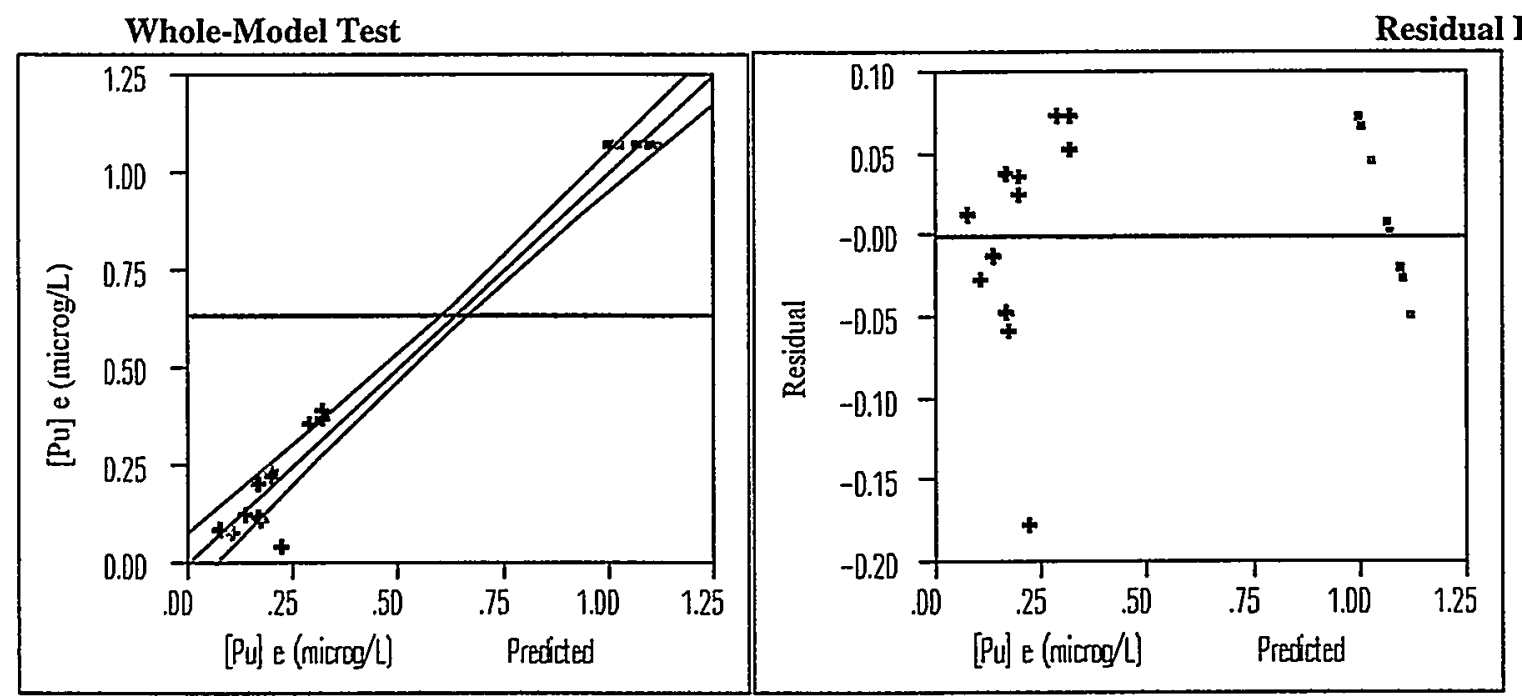

$\begin{array}{lrrrr}\text { Source } & \text { DF } & \text { Sum of Squares } & \text { Mean Square } & \text { F Ratio } \\ \text { Model } & 5 & 4.7151045 & 0.943021 & 228.1204 \\ \text { Error } & 18 & 0.0744097 & 0.004134 & \text { Prob }>\text { F } \\ \text { C Total } & 23 & 4.7895143 & & <.0001\end{array}$




\begin{tabular}{|c|c|c|c|c|}
\hline \multicolumn{5}{|c|}{$\begin{array}{c}\text { Response: }[\mathrm{U]} \text { e (microg/L) } \\
\text { Summary of Fit }\end{array}$} \\
\hline & \multicolumn{2}{|c|}{$\begin{array}{l}\text { RSquare } \\
\text { RSauare Adi }\end{array}$} & \multicolumn{2}{|l|}{0.988853} \\
\hline & \multicolumn{2}{|c|}{ RSquare Adj } & 0.984919 & \\
\hline & \multicolumn{2}{|c|}{ Root Mean Square Error } & 478.9525 & \\
\hline & \multicolumn{2}{|c|}{ Mean of Response } & 3874.471 & \\
\hline & \multicolumn{2}{|c|}{ Observations (or Sum Wgts) } & 24 & \\
\hline Source & DF & Sum of Squares & Mean Square & $\begin{array}{l}\text { Lack of Fit } \\
\text { F Ratio }\end{array}$ \\
\hline Lack of Fit & 11 & 2910301.1 & 264573 & 1.6044 \\
\hline Pure Error & 6 & 989422.4 & 164904 & Prob $>$ F \\
\hline Total Error & 17 & 3899723.5 & & 0.2909 \\
\hline
\end{tabular}

Max RSq

0.9972

Term
Intercept
Temp (Deg C)
[U]o (microg/L)
Temp (De*[U]o (mi
[U]o (mi*[U]o (mi
Spiked[SS-zNo]
Spiked[TPB-zNo]
Parameter Estimates

$\begin{array}{rr}\text { Estimate } & \text { Std Error } \\ 2710.9398 & 2388.599 \\ 0.8356381 & 9.738126 \\ -1.338496 & 1.178368 \\ -0.00313 & 0.001429 \\ 0.0000856 & 0.000056 \\ 489.93333 & 152.854 \\ -264.0167 & 152.854\end{array}$

t Ratio

1.13

0.09

$-1.14$

$-2.19$

1.53

3.21

$-1.73$
Prob $>|t|$

0.2721

0.9326

0.2718

0.0427

0.1432

0.0052

0.1022
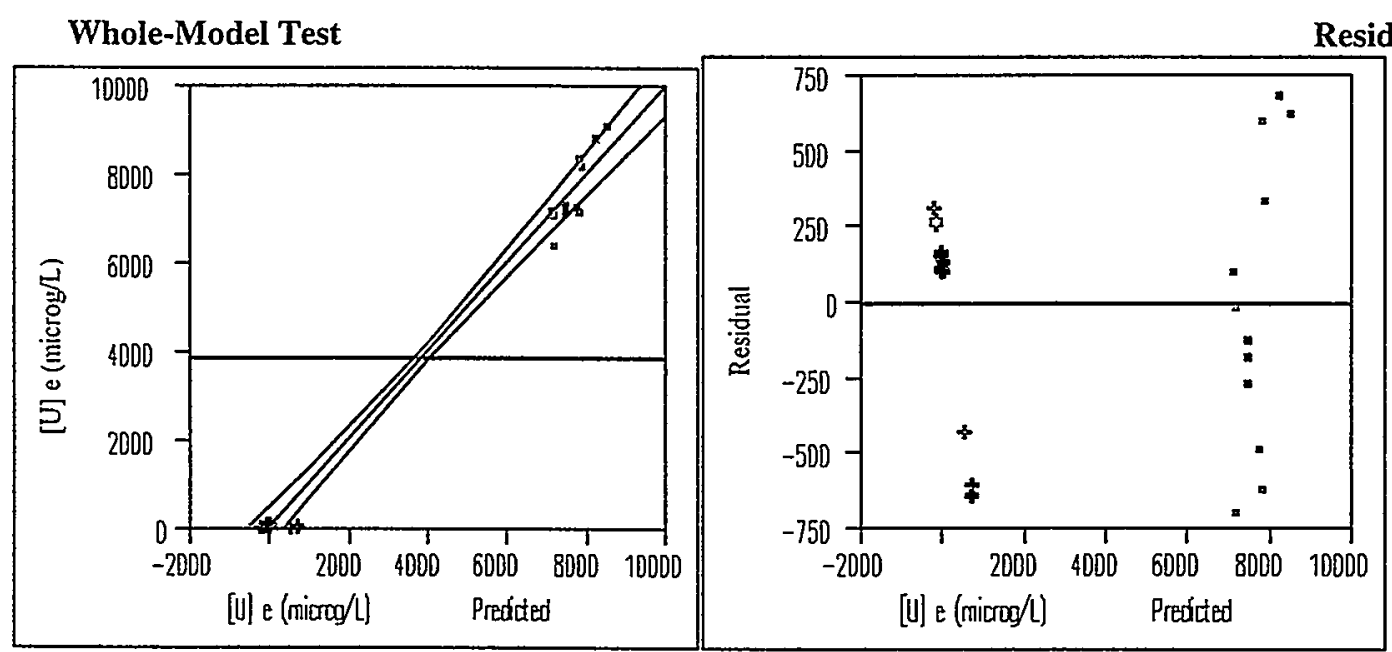

Analysis of Variance

Source

Model

Error

C Total
DIF

6

17

23
Sum of Squares

345954779

3899723

349854503
Mean Square

57659130

229395.5
F Ratio

251.3525

Prob $>$ F

$<.0001$ 


\section{Appendix 27.}

Statistical Analysis of Standard Trials

[Sr] e (microg/L) By Activity

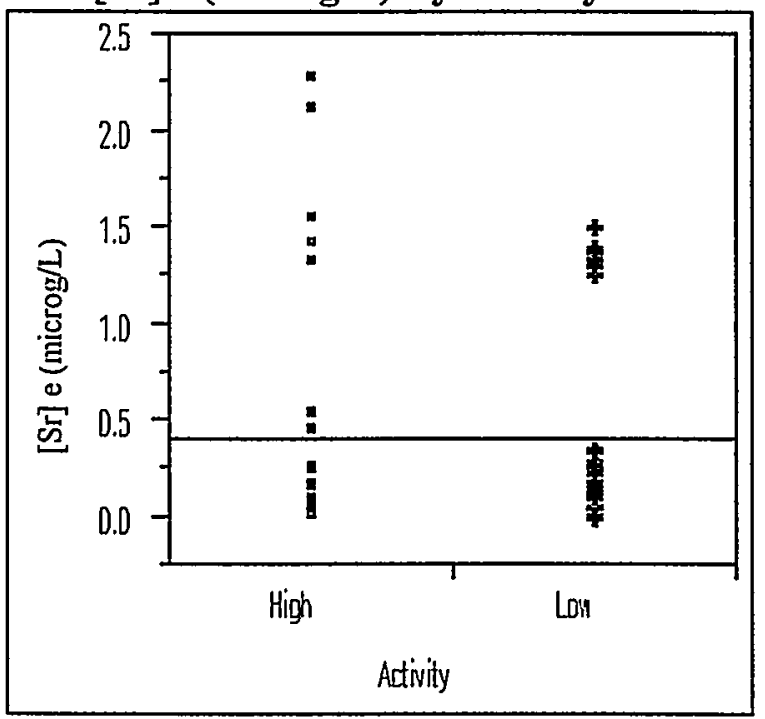

[Sr] e (microg/L) By Temp (Deg C)

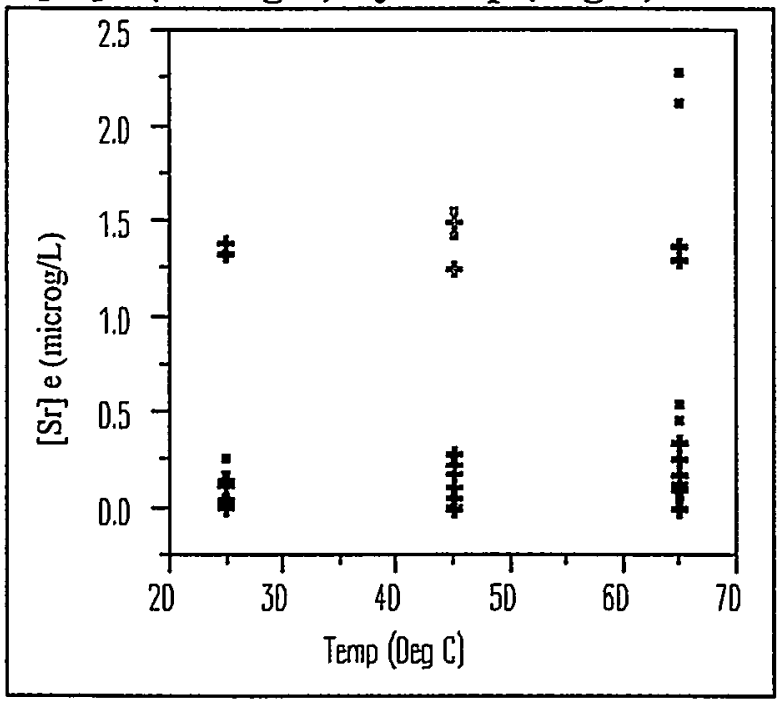

[Sr] e (microg/L) By MST (g/L)

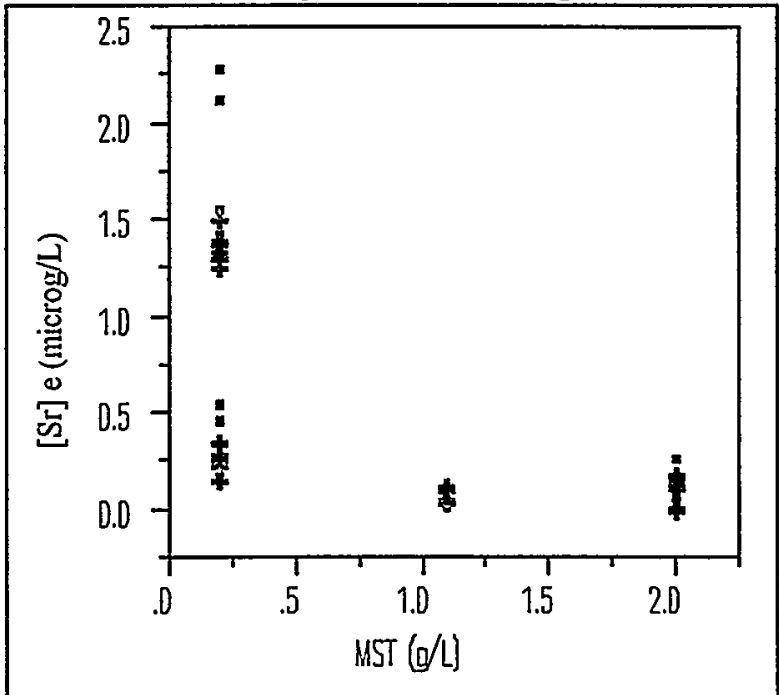

[Sr] e (microg/L) By Z (M)

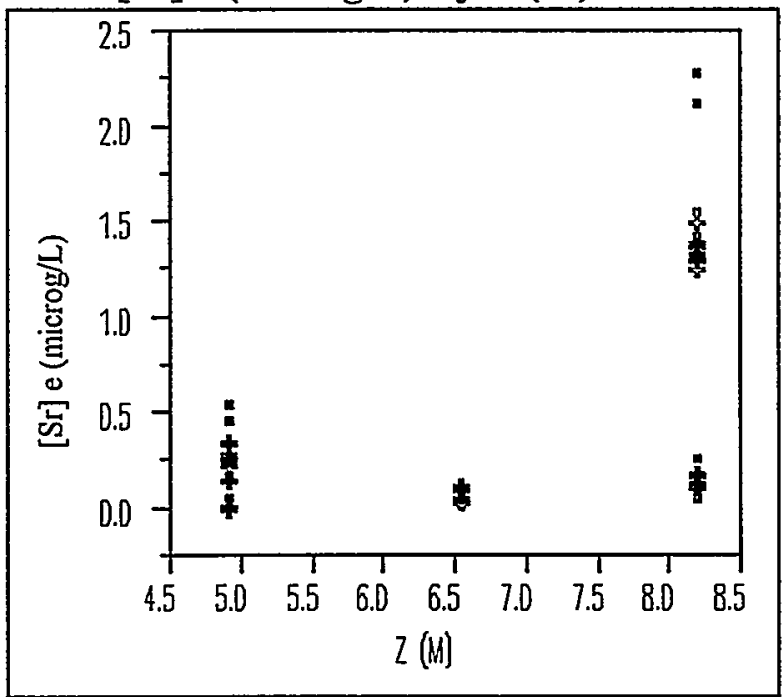


[Np] e (microg/L) By Activity

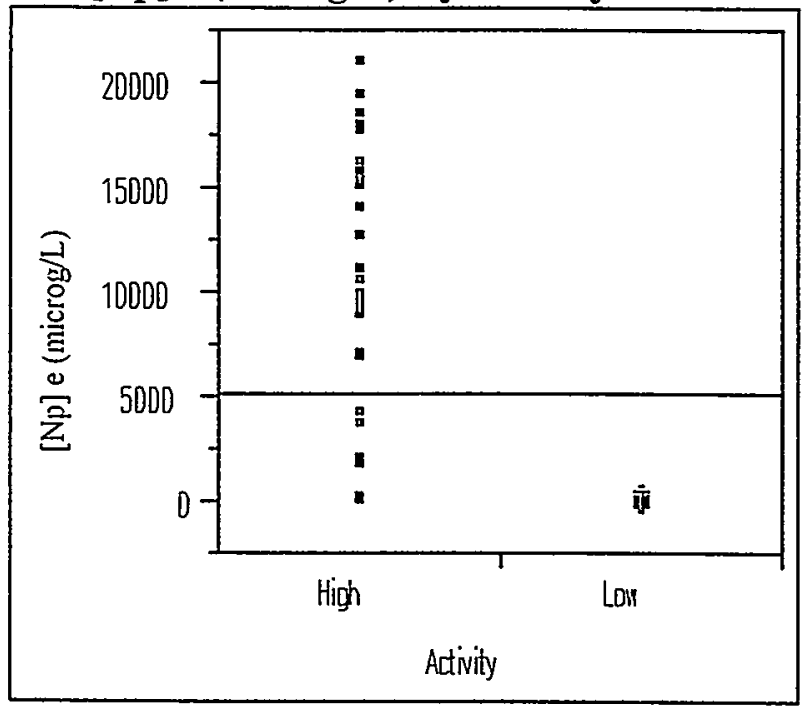

[Np] e (microg/L) By Temp (Deg C)

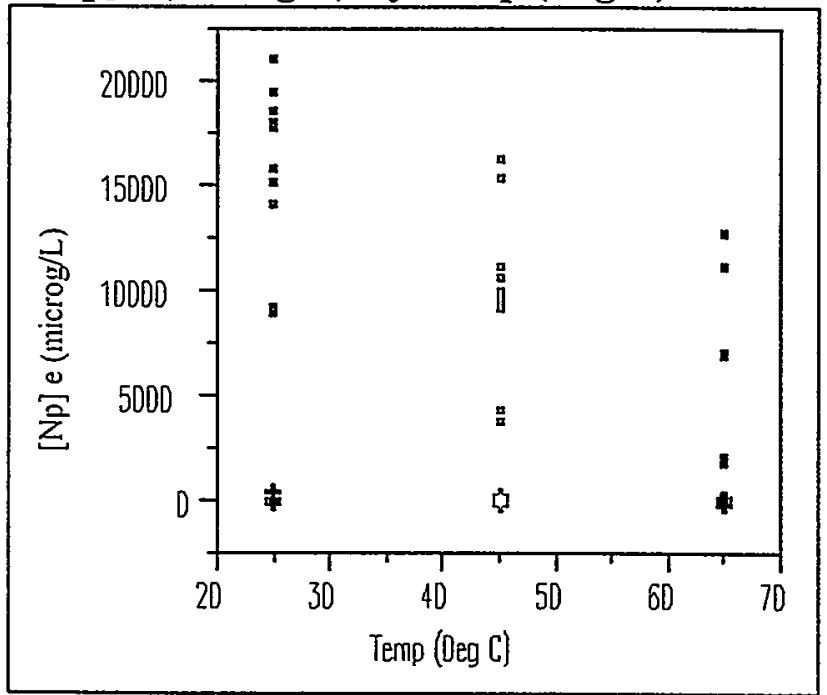

[Np] e (microg/L) By MST (g/L)

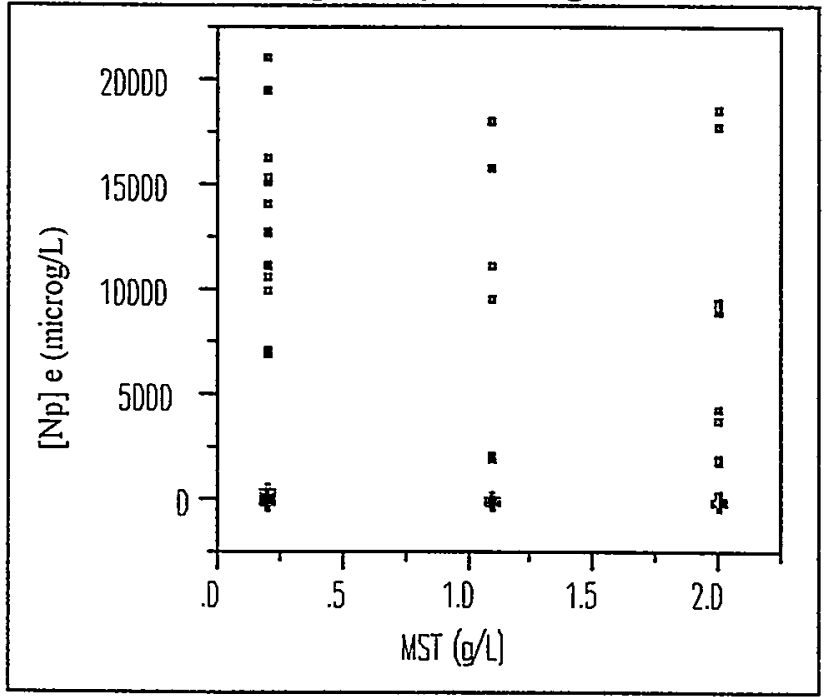

[Np] e (microg/L) By Z (M)

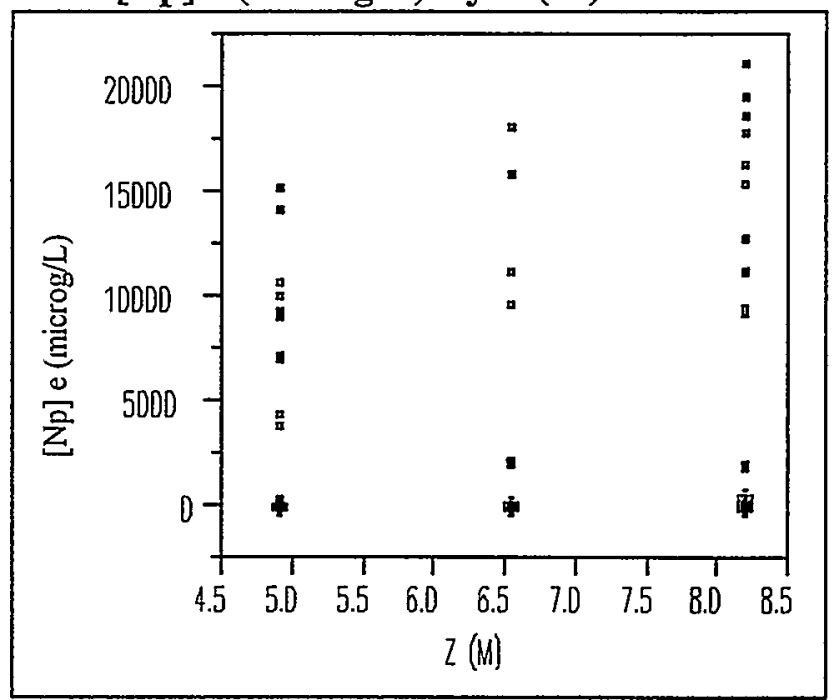

[U] e (microg/L) By Activity

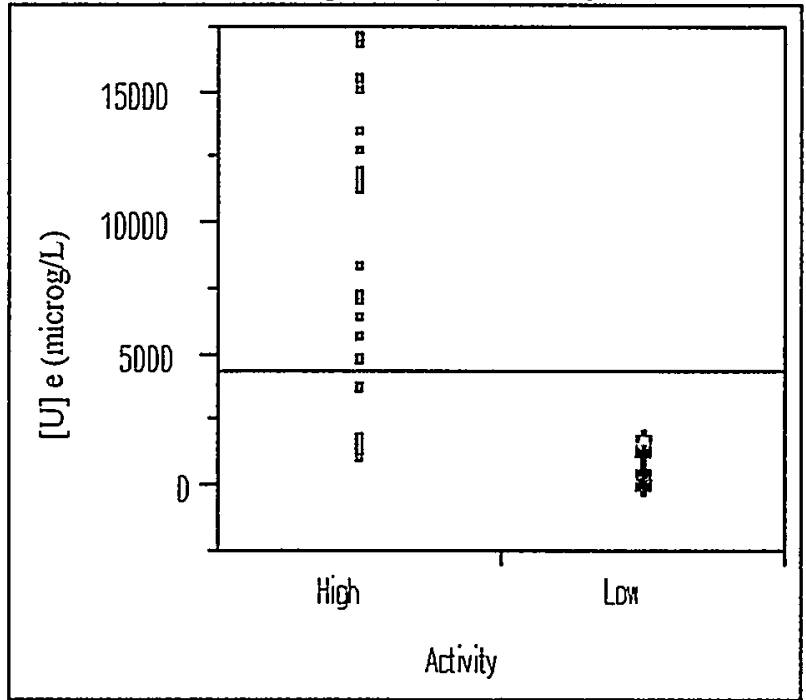

[U] e (microg/L) By Temp (Deg C)

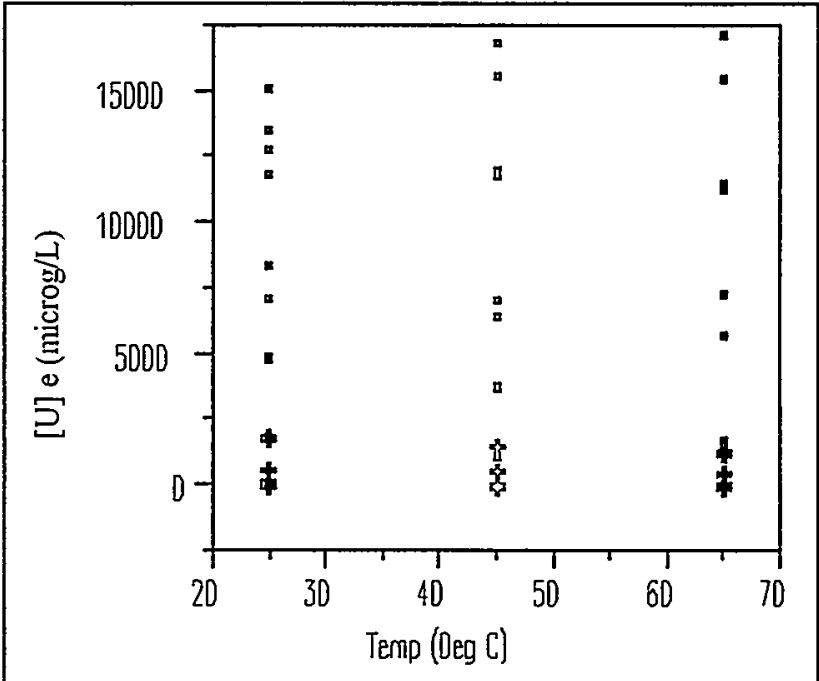




\section{[U] e (microg/L) By MST (g/L)}

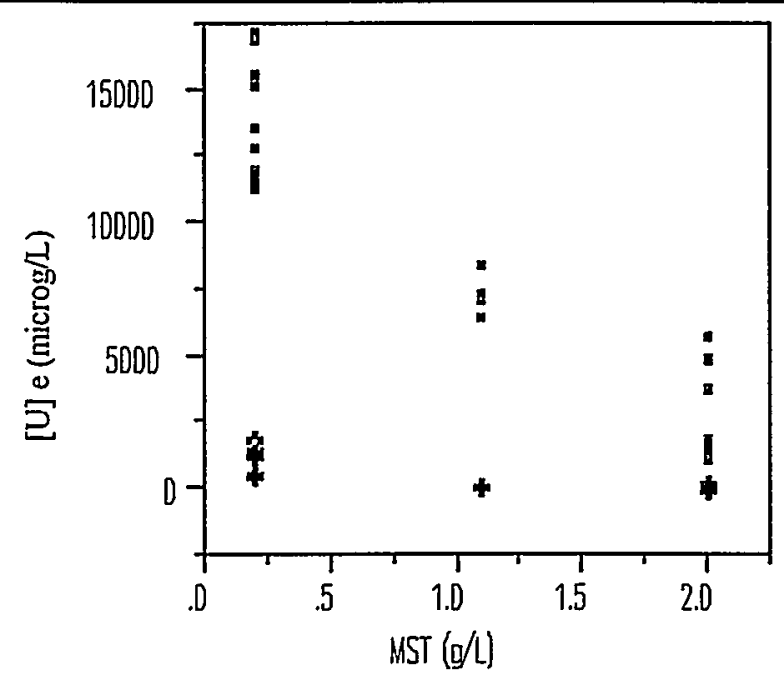

[U] e (microg/L) By Z (M)

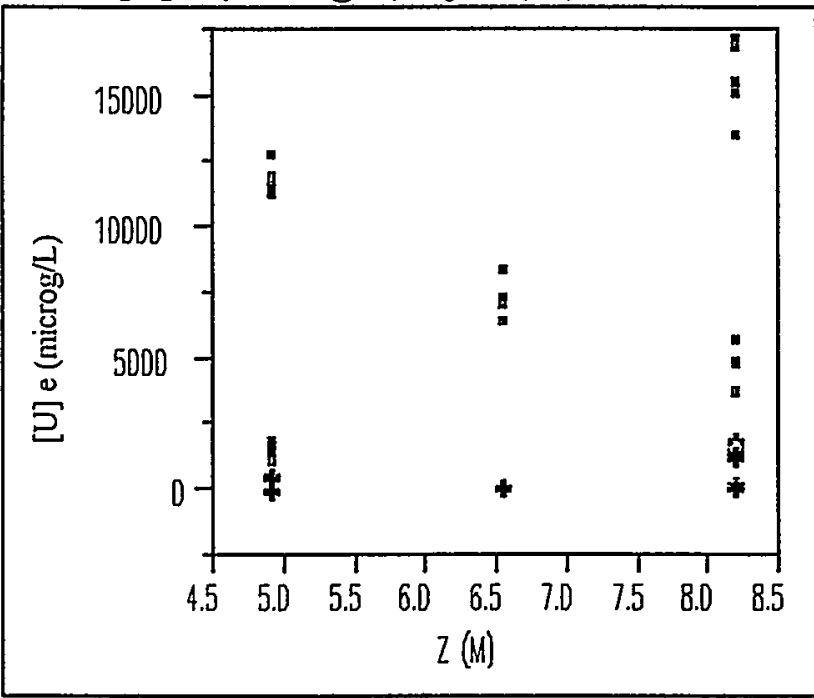

[Pu] e (microg/L) By Activity

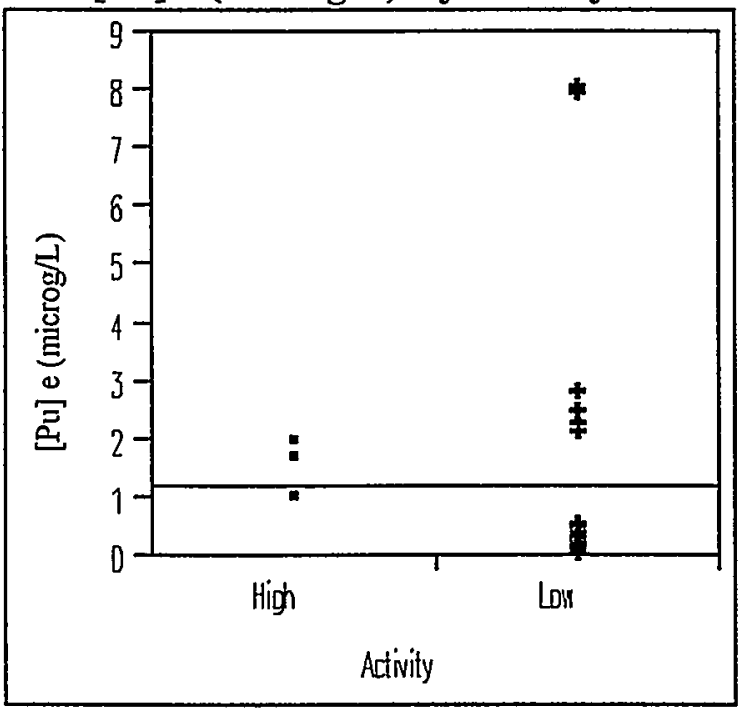

[Pu] e (microg/L) By Temp (Deg C)

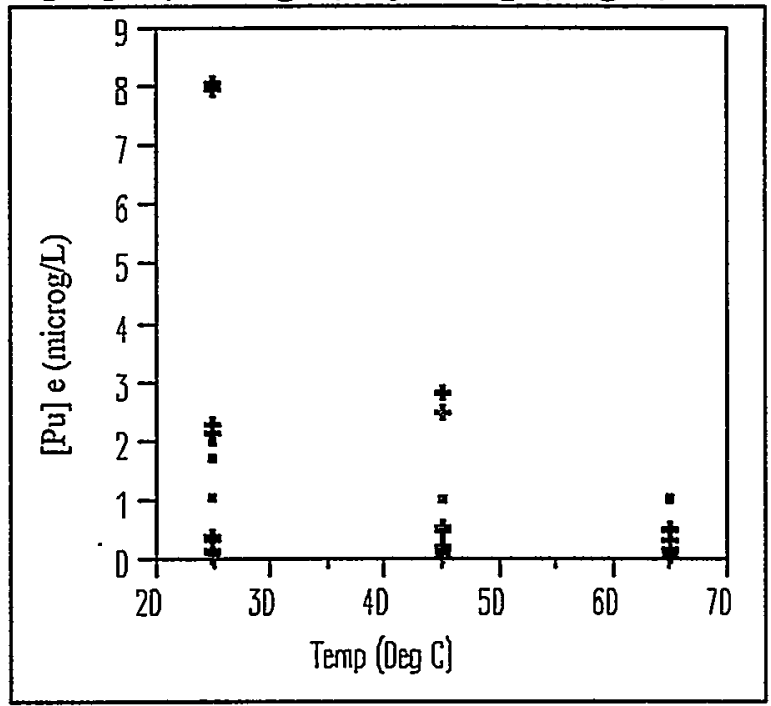

[Pu] e (microg/L) By MST (g/L)

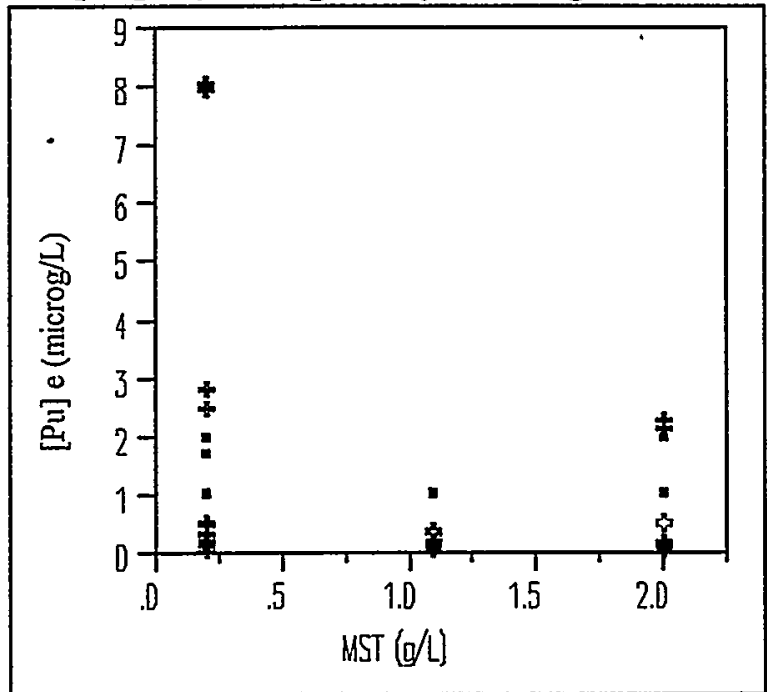

[Pu] e (microg/L) By Z (M)

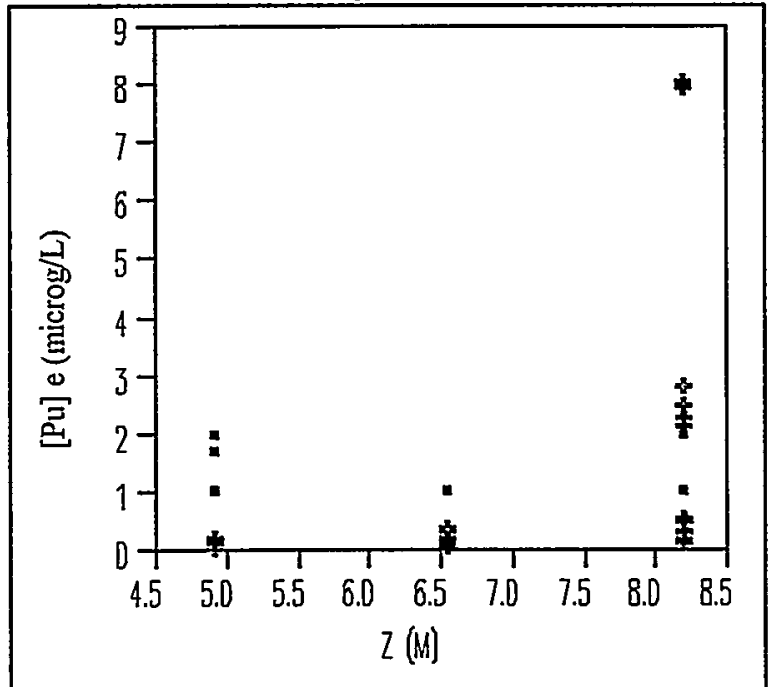




\section{Response: [Sr] e (microg/L)}

\section{Summary of Fit}

RSquare

0.972511

RSquare Adj

Root Mean Square Error

Mean of Response

Observations (or Sum Wgts)

Lack of Fit

Source

Lack of Fit

Pure Error

Total Error

Max RSq

0.9963

Term

Intercept

Temp (Deg C)

MST (g/L)

$\mathrm{Z}(\mathrm{M})$

[Sr]o (microg/L

MST (g/L*Temp (De

$\mathrm{Z}(\mathrm{M}) * \mathrm{MST}(\mathrm{g} / \mathrm{L}$

$\mathrm{Z}(\mathrm{M}) * \mathrm{Z}(\mathrm{M})$

[Sr]o ( $\mathrm{m} *$ Temp (De

[Sr]o ( $m *$ MST $(\mathrm{g} / \mathrm{L}$

[Sr]o $(m * Z(M)$

[Sr]o $(\mathrm{m} *[\mathrm{Sr}] \mathrm{o}(\mathrm{m}$
Sum of Squares

0.49333146

0.07587984

0.56921129
0.966212

0.108897

0.403816

60
F Ratio

10.8358

Prob $>$ F

$<.0001$
Parameter Estimates
Estimate
4.4260523
0.0057391
1.0220629
$-1.678261$
$-0.003138$
$-0.004937$
$-0.181079$
0.158784
0.0000832
$-0.001643$
$-0.001194$
0.000116

\section{Std Error}

0.545442

0.001746

0.086406

0.171502

0.002353

0.00107

0.011037

0.013139

0.000023

0.000466

0.000744

0.000052 t Ratio

8.11

3.29

11.83

$-9.79$

$-1.33$

$-4.62$

$-16.41$

12.09

3.64

$-3.53$

$-1.61$

2.21
Prob $>|t|$

$<.0001$

0.0019

$<0001$

$<.0001$

0.1887

$<.0001$

$<.0001$

$<.0001$

0.0007

0.0009

0.1148

0.0318

Whole-Model Test

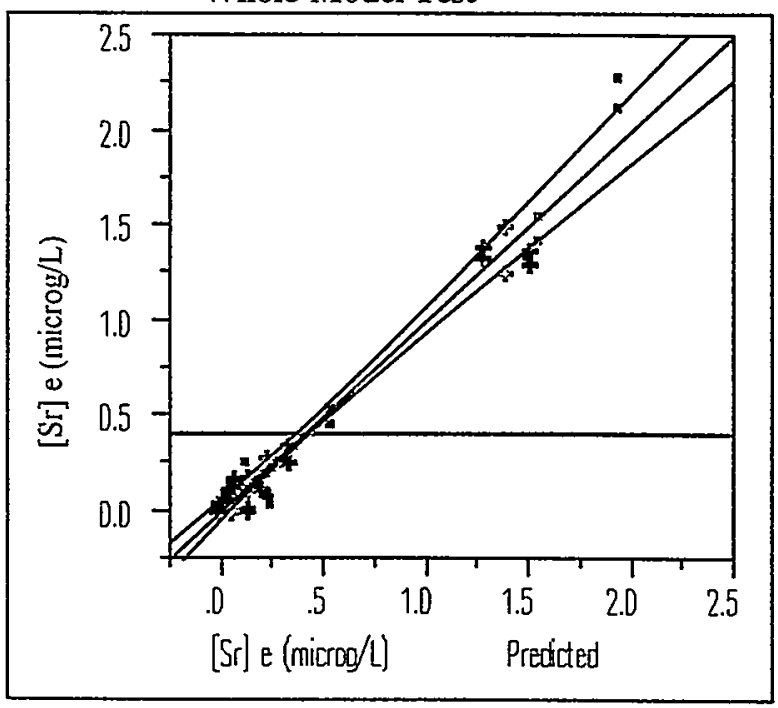

Residual Plot

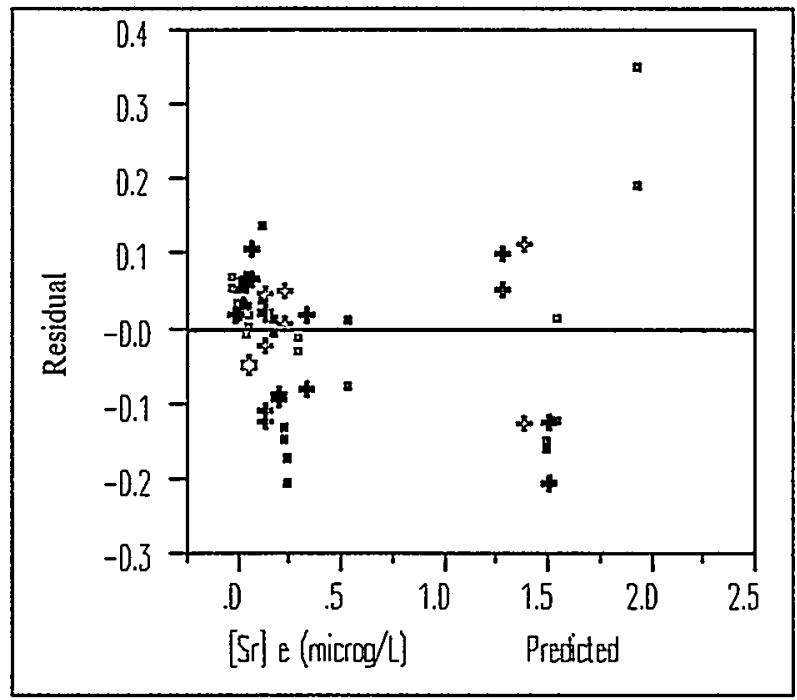

$\begin{array}{lr}\text { Source } & \text { DF } \\ \text { Model } & 11 \\ \text { Error } & 48 \\ \text { C Total } & 59\end{array}$

Analysis of Variance

48

59
Sum of Squares

20.137852

0.569211

20.707063
Mean Square

1.83071

0.01186
F Ratio

154.3790

Prob $>$ F

$<.0001$ 


\section{Response: [Np] e (microg/L)}

Summary of Fit

\section{RSquare}

RSquare Adj

Root Mean Square Error

Mean of Response

Observations (or Sum Wgts)

0.978018

0.974061

1078.153

5138.887

60

Source

Lack of Fit

Pure Error

Total Error

Max RSq

0.9970

\section{Term}

Intercept

Temp (Deg C)

MST (g/L)

$\mathrm{Z}(\mathrm{M})$

[Np]o (microg/L

MST (g/L*Temp (De

$Z(M) *$ Temp (De

$\mathrm{Z}(\mathrm{M}) * \mathrm{MST}(\mathrm{g} / \mathrm{L}$

[Np]o ( $m^{*}$ Temp (De

[Np]o ( $m *$ MST ( $g / L$

Lack of Fit

DF

20

30

50
Sum of Squares 50060484

8060220

58120704
Mean Square 2503024

268674
F Ratio 9.3162

Prob $>$ F

$<.0001$
Parameter Estimates

Estimate
2141.8395
-12.58601
-240.1614
-652.3456
0.9672846
-31.10862
8.5525546
238.24447
-0.010349
-0.116386

Std Error

2087.026

40.6197

855.3771

309.3746

0.032253

10.58849

5.952871

108.5936

0.000604

0.012242 t Ratio

1.03

$-0.31$

$-0.28$

$-2.11$

29.99

$-2.94$

1.44

2.19

$-17.13$

$-9.51$
Prob $>|t|$

0.3097

0.7580

0.7800

0.0400

$<.0001$

0.0050

0.1570

0.0329

$<.0001$

$<.0001$
Whole-Model Test

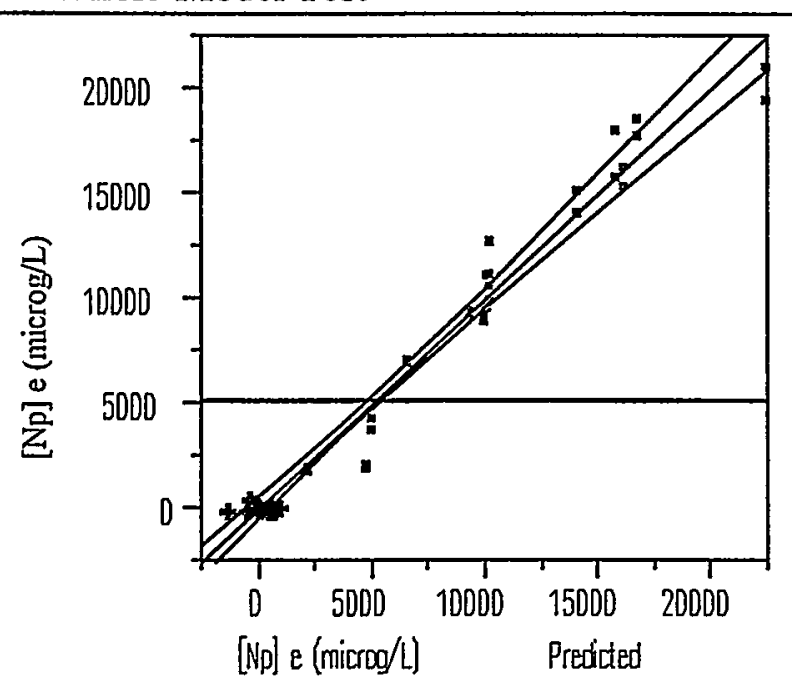

Residual Plot

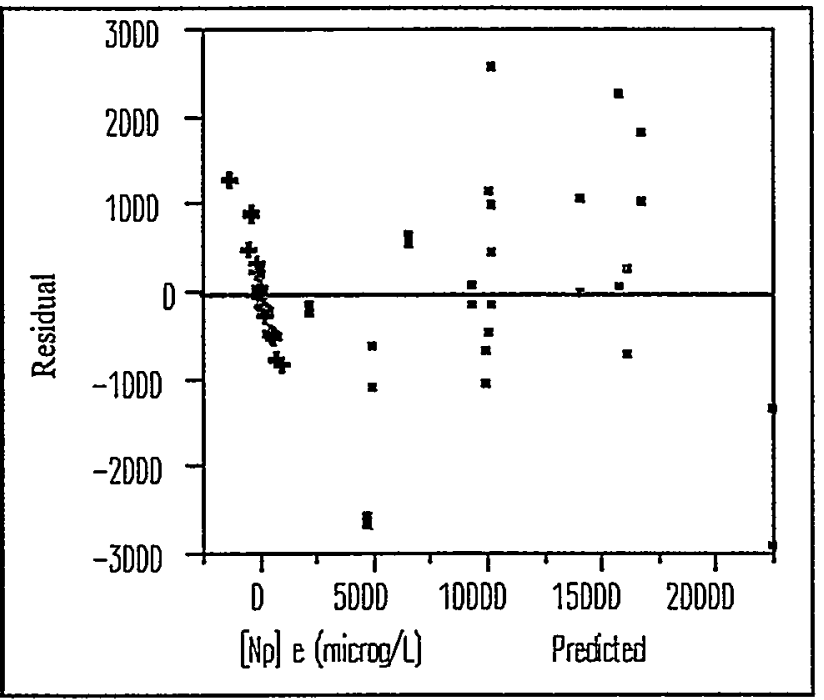

$\begin{array}{lr}\text { Source } & \text { DF } \\ \text { Model } & 9 \\ \text { Error } & 50 \\ \text { C Total } & 59\end{array}$

Analysis of Variance

Sum of Squares 2585854584 58120703.6 2643975288

\section{Mean Square $2.8732 \mathrm{e} 8$ \\ 1162414}

F Ratio
247.1728
Prob $>$ F
$<.0001$ 
Response: [Pu] e (microg/L) Summary of Fit

\section{RSquare}

RSquare Adj

Root Mean Square Error

Mean of Response

Observations (or Sum Wgts)

\section{Source \\ Lack of Fit \\ Pure Error \\ Total Error \\ Max RSq \\ 0.9989}

Term

Intercept

Temp (Deg C)

MST (g/L)

$Z(M)$

[Pu]o (microg/L

Temp (De*Temp (De

MST (g/L*Temp (De

$\mathrm{Z}(\mathrm{M}) *$ Temp (De

$\mathrm{Z}(\mathrm{M}) * \mathrm{MST}(\mathrm{g} / \mathrm{L}$

$\mathrm{Z}(\mathrm{M}) * \mathrm{Z}(\mathrm{M})$

[Pu]o (m*MST $(\mathrm{g} / \mathrm{L}$

[Pu]o (m*Z (M)

[Pu]o $(\mathrm{m} *[\mathrm{Pu}] \mathrm{O}(\mathrm{m}$
Lack of Fit

DF

18

29

47
Sum of Squares

26.638479

0.138414

26.776893

\section{Parameter Estimates}

Estimate
7.4014219
-0.053605
0.2756018
-2.130129
0.0187144
0.0013112
0.0195974
-0.019199
-0.302035
0.2943405
0.0041287
0.0122774
-0.00046

0.789178

0.735351

0.754799

1.190233

60

Mean Square

1.47992

0.00477

$\begin{array}{rrr}\text { Std Error } & \text { t Ratio } & \text { Prob }>\mid \text { t| } \\ 4.06853 & 1.82 & 0.0753 \\ 0.055159 & -0.97 & 0.3361 \\ 0.598912 & 0.46 & 0.6475 \\ 1.201773 & -1.77 & 0.0828 \\ 0.004975 & 3.76 & 0.0005 \\ 0.000522 & 2.51 & 0.0155 \\ 0.007416 & 2.64 & 0.0111 \\ 0.004057 & -4.73 & <.0001 \\ 0.075931 & -3.98 & 0.0002 \\ 0.090731 & 3.24 & 0.0022 \\ 0.001095 & 3.77 & 0.0005 \\ 0.003746 & 3.28 & 0.0020 \\ 0.000108 & -4.27 & <.0001\end{array}$

F Ratio

310.0665

Prob $>$ F

$<.0001$
Whole-Model Test

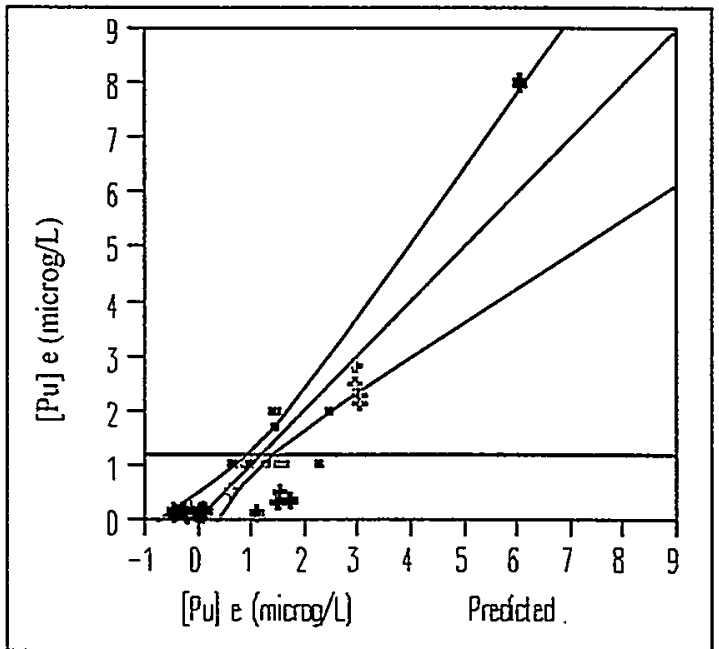

Residual Plot

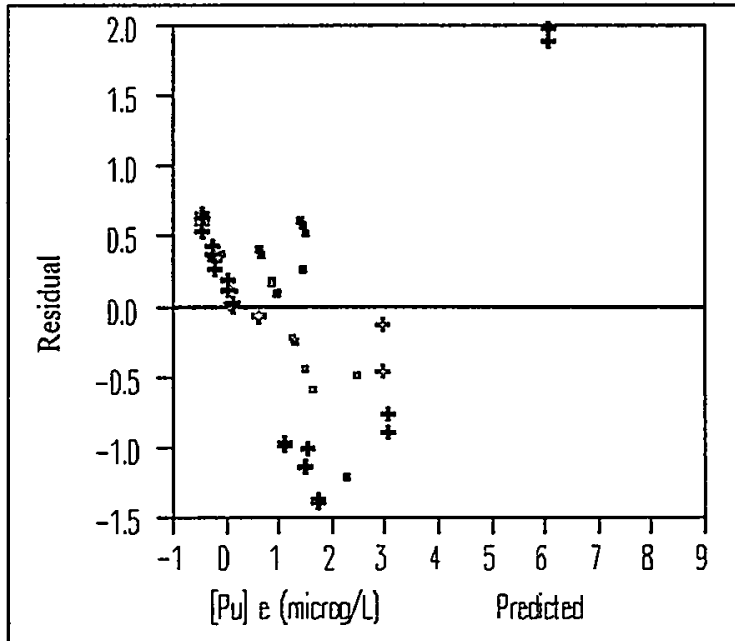

$\begin{array}{lr}\text { Source } & \text { DF } \\ \text { Model } & 12 \\ \text { Error } & 47 \\ \text { C Total } & 59\end{array}$

Analysis of Variance

Sum of Squares 100.23506

26.77689

127.01195
Mean Square

8.35292

0.56972
F Ratio 14.6614

Prob $>$ F $<.0001$ 
Response: [U] e (microg/L) Summary of Fit

RSquare

RSquare Adj

Root Mean Square Error

Mean of Response

Observations (or Sum Wgts)

Lack of Fit

Source
Lack of Fit
Pure Error
Total Error
Max RSq
0.9972

Term

Intercept

MST (g/L)

$\mathrm{Z}(\mathrm{M})$

[U]o (microg/L)

$\mathrm{Z}(\mathrm{M}) * \mathrm{MST}(\mathrm{g} / \mathrm{L}$

$\mathrm{Z}(\mathrm{M}) * \mathrm{Z}(\mathrm{M})$

[U]o (mi*MST (g/L

[U]o (mi*Z (M)
Sum of Squares

31509027

4678700

36187726
Parameter Estimates

Estimate

15483.209

$-2484.638$

$-4647.965$

0.8238358

349.48268

328.50277

$-0.274538$

$-0.013684$
0.97865

0.975776

834.2169

4365.92

60

Mean Square

1432228

155957

F Ratio

9.1835

Prob $>$ F

$<.0001$
Std Error

4134.61

549.6486

1314.154

0.064824

84.79758

100.5494

0.014271

0.008611

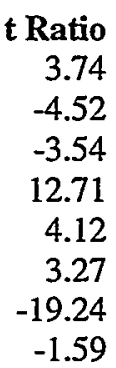

Prob $>|t|$

0.0005

$<.0001$

0.0009

$<.0001$

0.0001

0.0019

$<.0001$

0.1181

Whole-Model Test

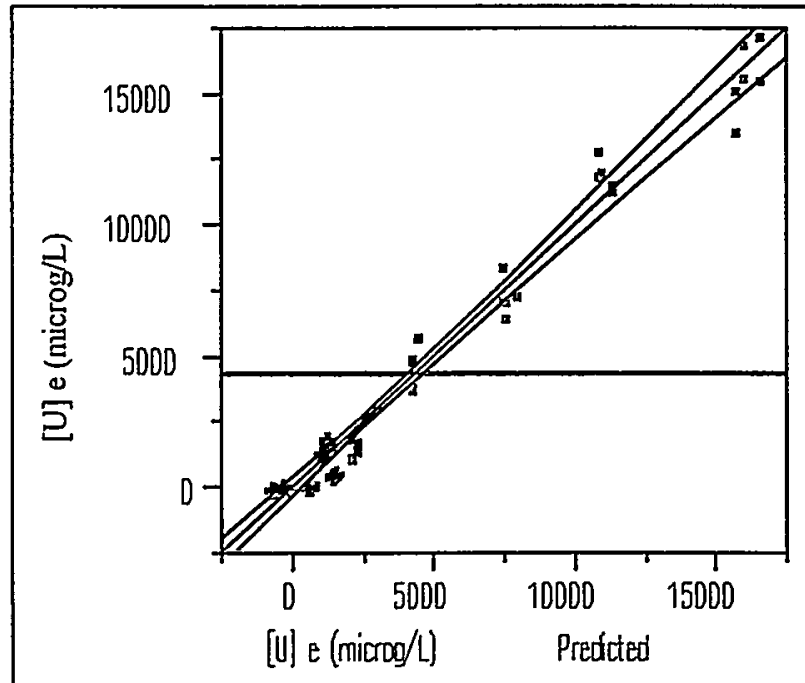

Residual Plot

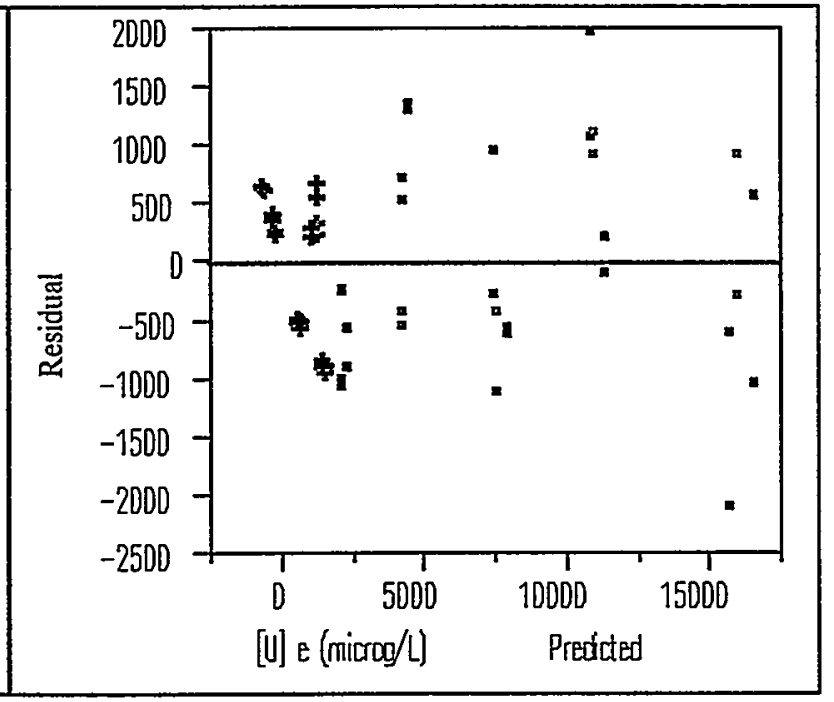

$\begin{array}{lr}\text { Source } & \text { DF } \\ \text { Model } & 7 \\ \text { Error } & 52 \\ \text { C Total } & 59\end{array}$

Analysis of Variance

Sum of Squares

1658818781

36187726.2

1695006507
Mean Square

$2.3697 \mathrm{e} 8$

695917.8
F Ratio

340.5203

Prob $>$ F

$<.0001$ 
Prediction Limits and Measurements Versus Model Predictions for [Sr] e (microg/L)

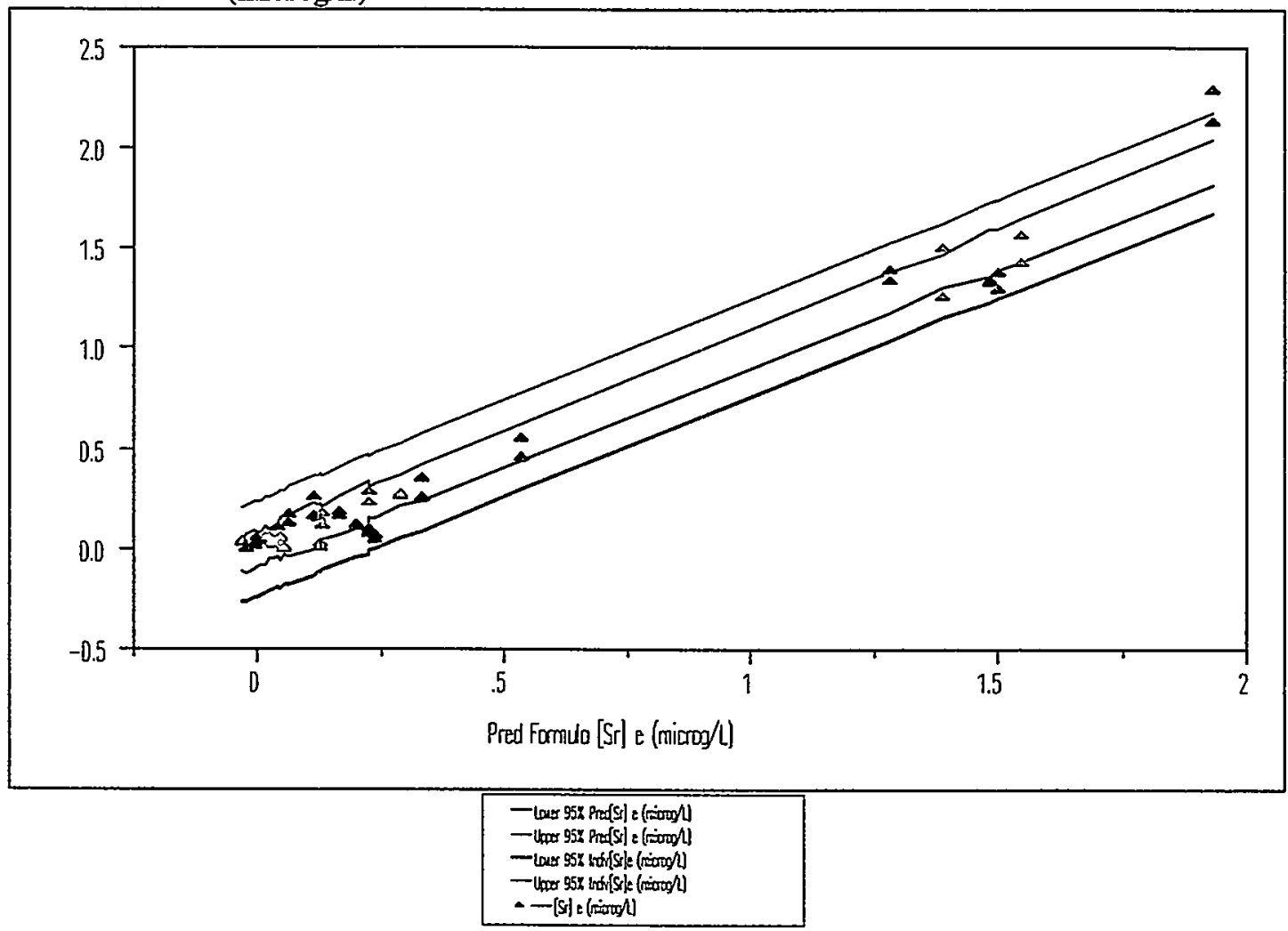

Prediction Limits and Measurements Versus Model Predictions for [Np] e (microg/L)

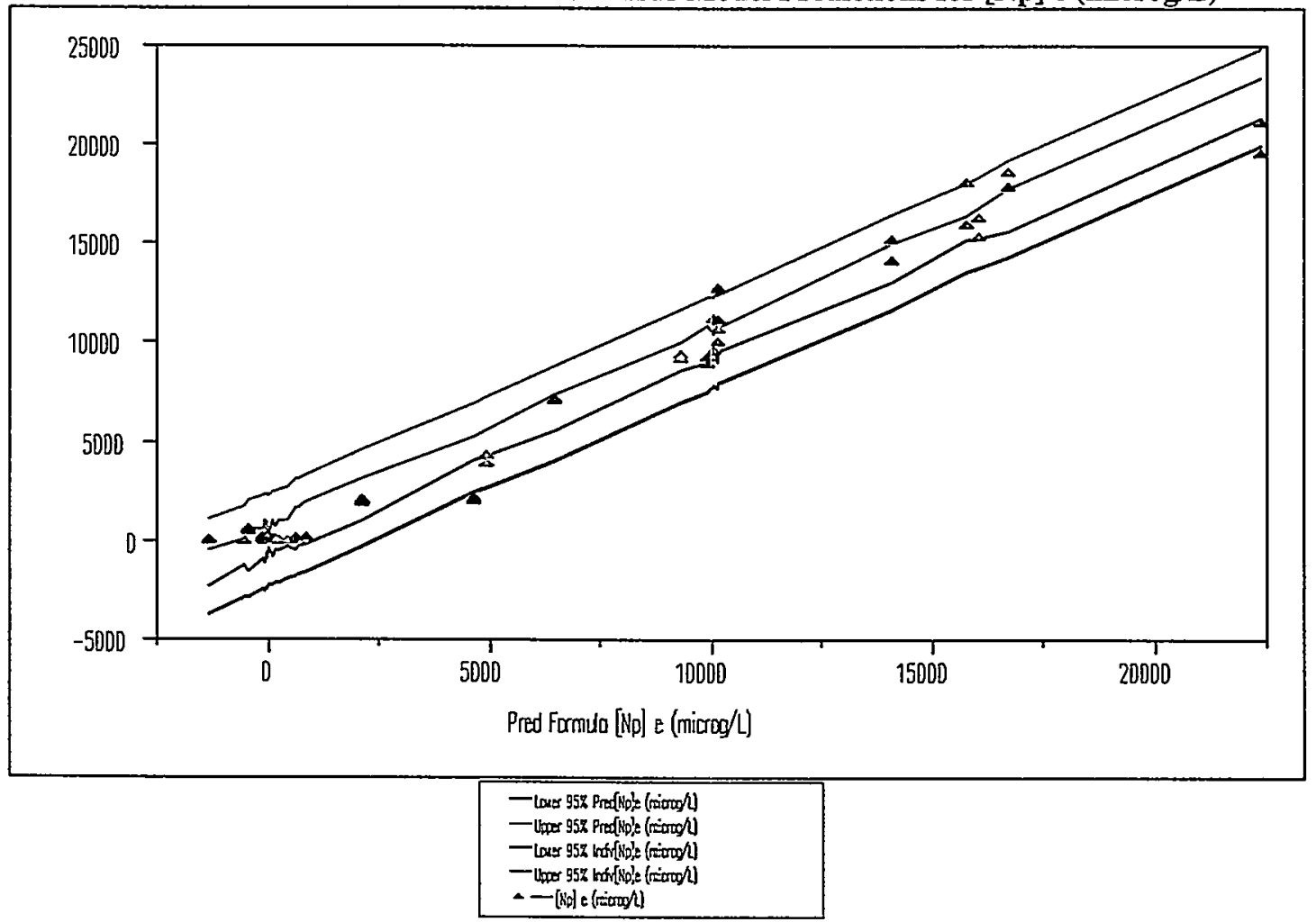


Prediction Limits and Measurements Versus Model Predictions for $[\mathrm{Pu}]$ e (microg/L)

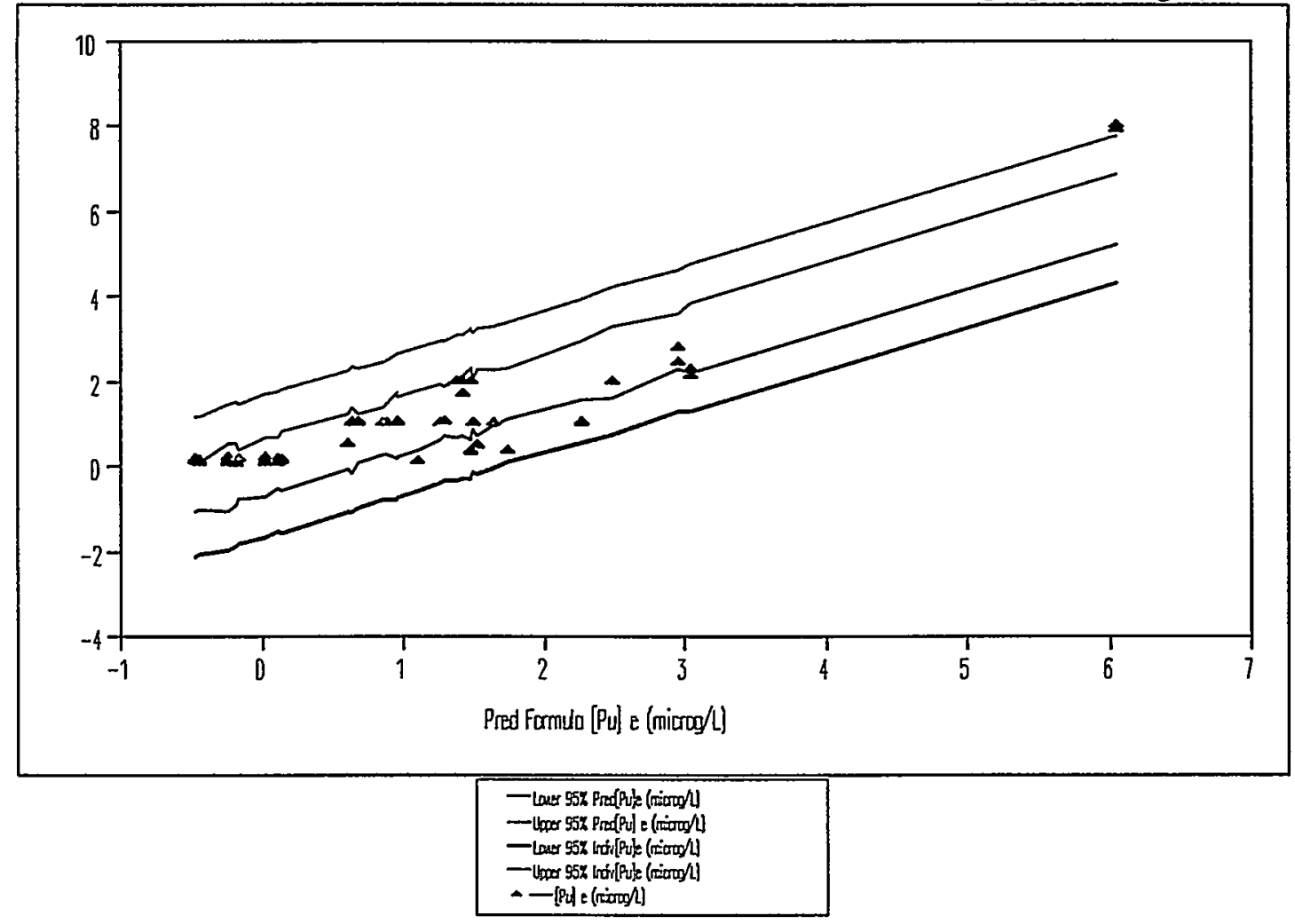

Prediction Limits and Measurements Versus Model Predictions for [U] e (microg/L)

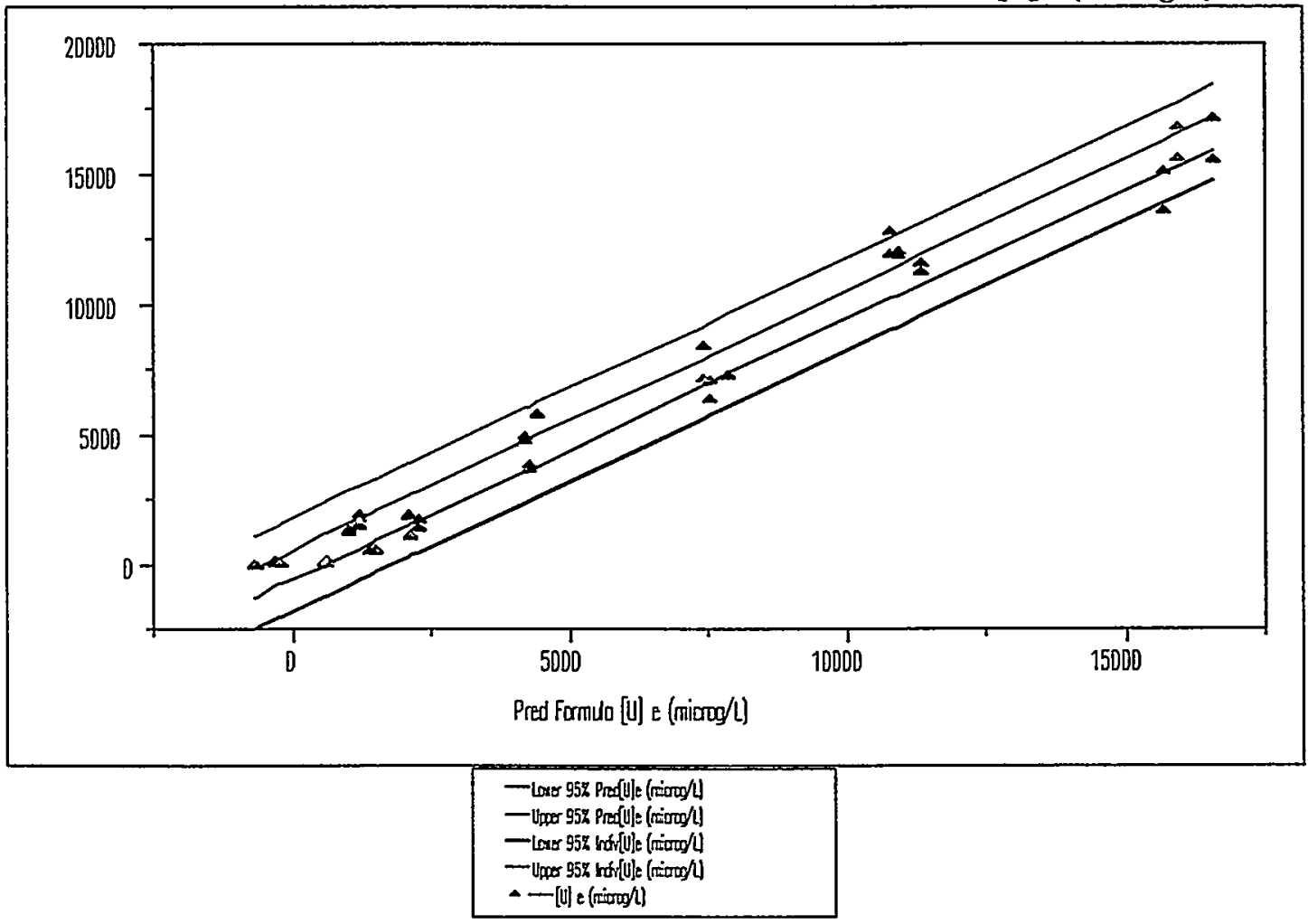




\section{DISTRIBUTION}

J. L. Barnes, 704-3N

M. J. Barnes, 773-A

T. E. Britt, 703-H

M. G. Bronikowski, 773-A

J. T. Carter, 704-3N

W. C. Clark, 704-56H

T. B. Edwards, 773-42A

H. H. Elder, 704-196N

F. F. Fondeur, 773-A

J. R. Fowler, 704-196N

D. T. Hobbs, 773-A

E. W. Holtzscheiter, 773-A

R. A. Jacobs, 704-196N

R. T. Jones, $704-3 \mathrm{~N}$

L. F. Landon, 704-T

B. L. Lewis, 703-H

T. J. Lex, 703-H

P. E. Lowe, 773-41 A

D. J. McCabe, 773-42A

J. W. McCollough, 704-3N

J. P. Morin, 703-H

L. M. Nelson, 773-43A

L. M. Papouchado, 773-A

S. F. Piccolo, 704-3N

R. A. Peterson, 773-41A

S. F. Peterson, 773-41A

J. A. Pike, 704-3N

R. L. Pulmano, 773-24A

K. J. Rueter, 704-3N

P. L. Rutland, 704-196N

M. G. Schwenker, 703-46A

R. H. Spires, 703-H

W. E. Stevens, 773-A

P. C. Suggs, 704-196N

G. A. Taylor, $704-196 \mathrm{~N}$

W. L. Tamosaitis, 773-A

W. B. Van Pelt, 773-43A

D. D. Walker, 773-A

W. R. Wilmarth, 773-42A

G. T. Wright, 773-A

TIM, 703-43A

LWP Files c/o C. Canada, 773-A

ITP Files c/o C. Smalls, 241-147H 